\title{
Functional morphology, evolution and systematics of Early Palaeozoic univalved molluscs
}

\section{G E U S}

Report file no.

\section{3}

John S. Peel

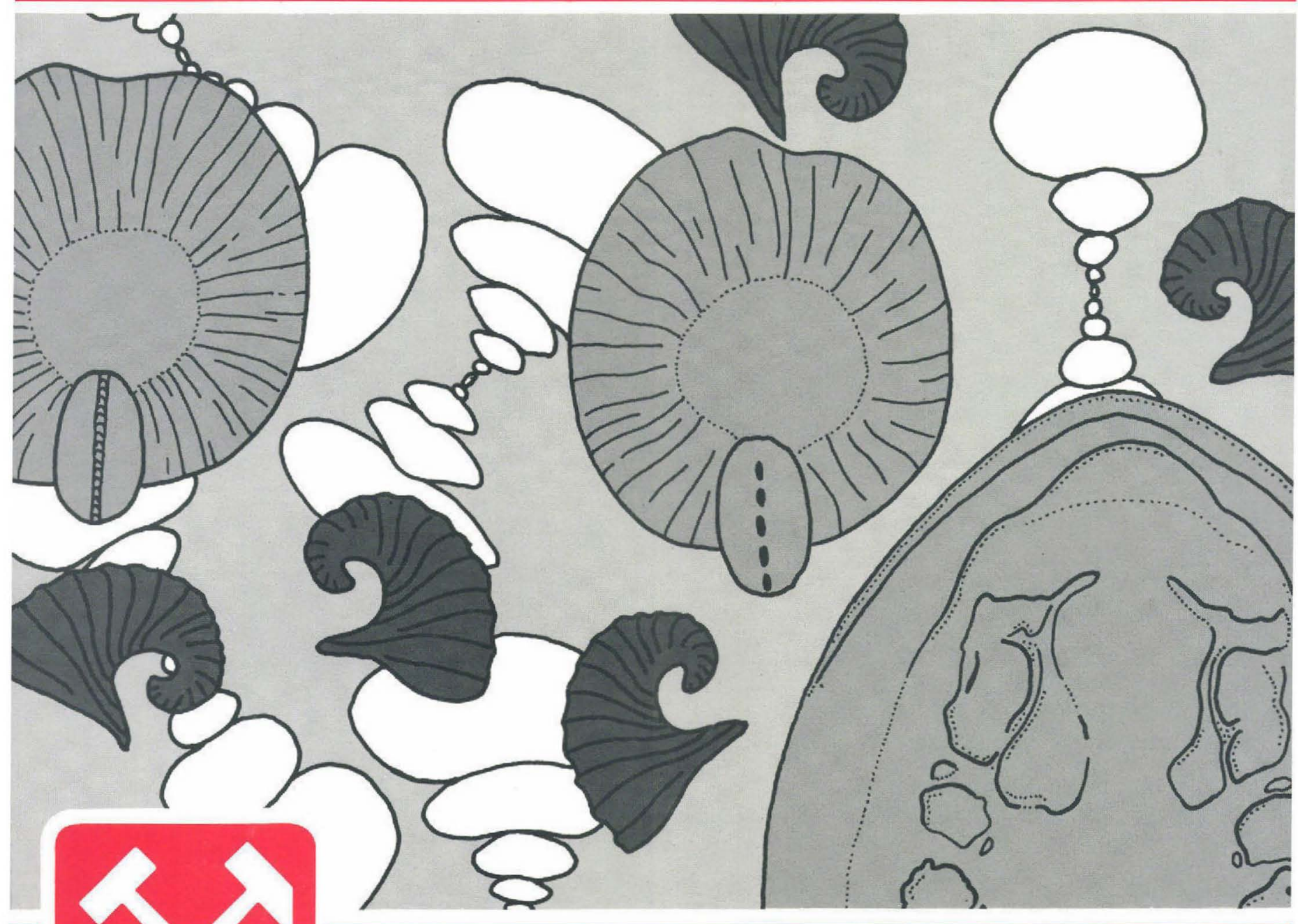

GRØNLANDS GEOLOGISKE UNDERSØGELSE

GGU Bulletin 161 


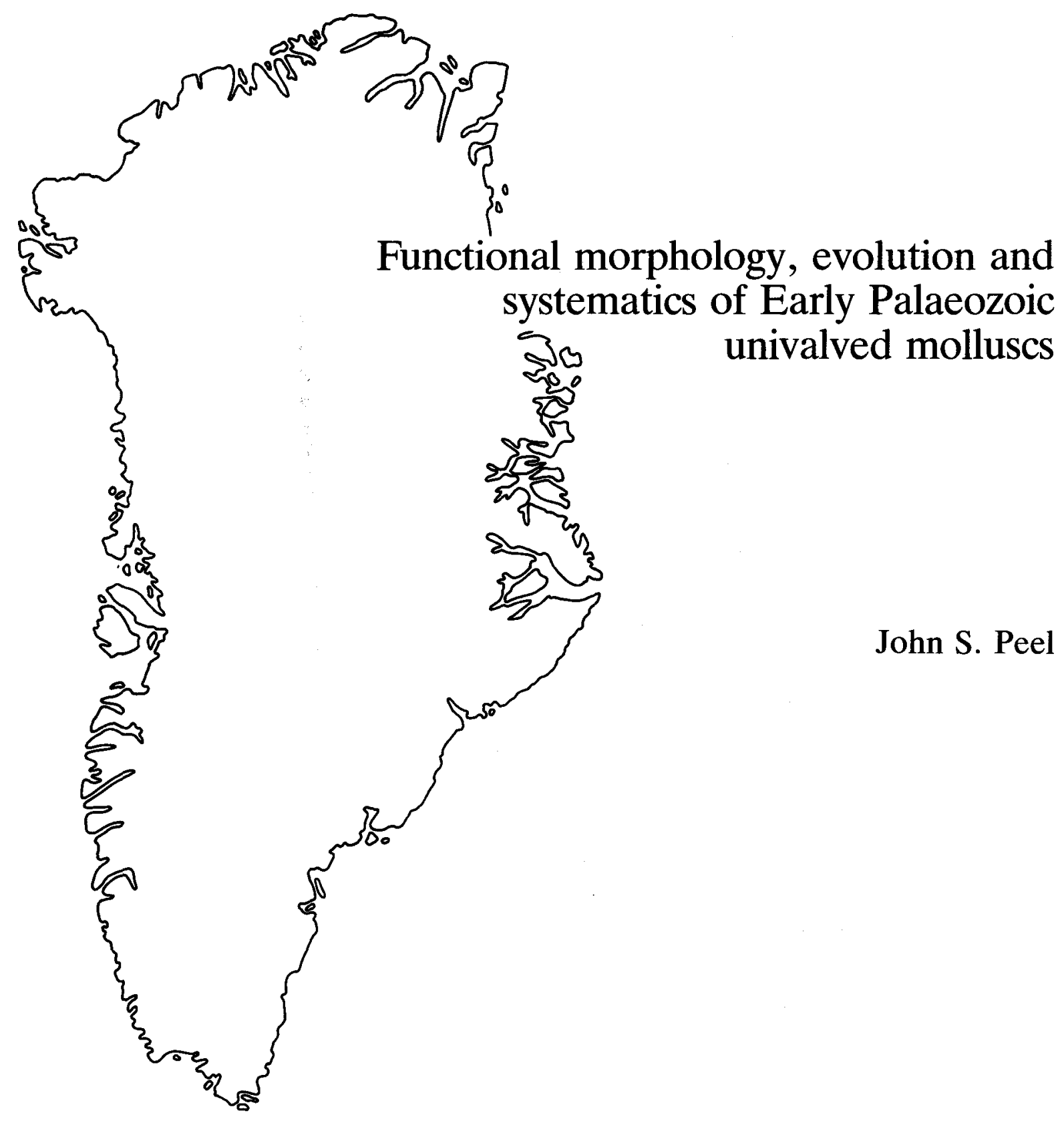


Peel, J. S. 1991: Functional morphology, evolution and systematics of Early Palaeozoic univalved molluscs. Bull. Grønlands geol. Unders. 161, 116 pp.

This bulletin contains two papers describing aspects of the functional morphology and systematics of Early Palaeozoic untorted molluscs and bellerophontacean gastropods. A brief discussion of the potential role in early molluscan evolution of articulated halkieriids recently discovered from the Lower Cambrian of North Greenland forms an introduction to the volume.

In the first paper, untorted molluscs previously referred to the now abandoned Class Monoplacophora are examined from a functional morphological perspective. Two major lineages are recognised on the basis of the direction of coiling of the shell. In the Class Tergomya (Cambrian-Recent), which includes Tryblidium, Pilina and the living Neopilina, the shell is coiled exogastrically, i.e. with the apex at the front and the shell expanding towards the rear. In the endogastrically coiled Class Helcionelloida (Cambrian), the shell apex lies at the posterior and the shell expands anteriorly. The Order Hypseloconida nov. is one of three orders proposed within the Class Tergomya.

Recognition of the classes Tergomya and Helcionelloida promotes a discussion of the status of the sub- phyla Diasoma and Cyrtosoma; use of these terms is discontinued. Theories concerning the relationships of early molluscs are discussed against the background of the earliest Cambrian fossil record.

The second paper examines the development of a single morphological feature within a group of Ordovician-Devonian bellerophontacean gastropods, namely the modification of the median dorsal slit to form a single perforation (trema) or series of perforations (tremata). Material for this study is provided by a sequence of Silurian species of Bucania, Salpingostoma and Megalomphala from Greenland and Sweden, following revision of type material of the latter two genera from the Ordovician of the eastern Baltic region. The genus Offleya from the Silurian of North Greenland is re-described and the status of the genera Tremanotus and Boiotremus is discussed.

New species: Bucania groenlandica, B. stephnae, Salpingostoma martinssoni, Megalomphala gotlandica, $M$. marjorae, $M$. wilfredi and $M$. dawesi. Salpingostoma septentrionale is assigned to Megalomphala.

Editor's address:

Geological Survey of Greenland, $\varnothing$ ster Voldgade 10 , DK-1350 Copenhagen K, Denmark.

\section{Grønlands Geologiske Undersøgelse Kalaallit Nunaanni Ujarassiortut Misissuisoqarfiat Geological Survey of Greenland}

The Geological Survey of Greenland (GGU) is a research institute affiliated to the Mineral Resources Administration for Greenland (MRA) within the Danish Ministry of Energy. As with all other activities involving the non-living resources in Greenland, GGU's investigations are carried out within the framework of the policies decided jointly by the Greenland Home Rule Authority and the Danish State. 


\section{Contents}

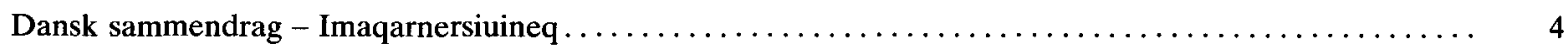

Introduction - articulated halkieriids and microchitons $\ldots \ldots \ldots \ldots \ldots \ldots \ldots \ldots \ldots \ldots \ldots$. S. Peel 5

The Classes Tergomya and Helcionelloida, and early molluscan evolution $\ldots \ldots \ldots \ldots \ldots \ldots . J . \quad$. Peel 11

Monoplacophora: historical usage............ 11

Monoplacophora: current usage . . . . . . . . . . 16

The question of size.................... 19

Class Tergomya...................... 20

Cyclomya - gastropods or monoplacophores? ..... 20

The ancestral condition .................. 22

Sub-class Cyclomya abandoned ............. 23

Gastropods or retractile tergomyans............ 24

Tergomyan classification $\ldots \ldots \ldots \ldots \ldots \ldots \ldots \ldots, 28$

Class Tergomya ....................... 28

Order Tryblidiida Lemche, $1957 \ldots \ldots \ldots \ldots \ldots \ldots .28$

Order Cyrtonellida Horny, 1963a . . . . . . . . . . . 29

Order Hypseloconida (new) . . . . . . . . . . . . 29

Class Helcionelloida. . . . . . . . . . . . . . . . . . . . . 29

Order Eomonoplacophora .................. 30

Classification of helcionelloids .............. 30

Functional morphology of the Class Helcionelloida. . . 31

The mantle cavity in Latouchella ............ 31

The function of the snorkel in Yochelcionella...... 36

Snorkel development in Eotebenna............. 37

The temporary snorkel of Oelandia ............ 40

Mode of life of Eurekapegma ............. 42
Protowenella, a strongly coiled helcionelloid ....... 42

Helcionelloids and rostroconchs ............... 44

Rostroconch orientation ................ 44

Pegma-like structures.................. 45

Origin of the cephalopods $\ldots \ldots \ldots \ldots \ldots \ldots \ldots \ldots, 46$

The Knightoconus hypothesis. . . . . . . . . . 47

Pseudo-endogastric and pseudo-exogastric ........ 50

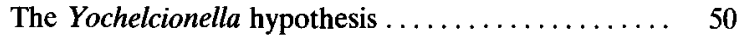

The helcionelloid hypothesis $\ldots \ldots \ldots \ldots \ldots \ldots \ldots, 51$

Diasoma and Cyrtosoma.................. 52

The polyphyletic Diasoma $\ldots \ldots \ldots \ldots \ldots \ldots \ldots \ldots, 52$

Status of the Sub-phylum Cyrtosoma ........... 53

Ancestral conchiferans $\ldots \ldots \ldots \ldots \ldots \ldots \ldots \ldots \ldots, \quad 55$

Helcionelloid muscle scars ................. 56

The earliest Cambrian molluscs.............. 57

Scaly and granular shells............... 57

Helcionelliform shells ................. 57

Direction of coiling $\ldots \ldots \ldots \ldots \ldots \ldots \ldots \ldots \ldots, 58$

Discussion .......................... 59

Acknowledgements $\ldots \ldots \ldots \ldots \ldots \ldots \ldots \ldots \ldots \ldots \ldots, \quad 60$

References........................ 61

Salpingostoma and related bellerophontacean gastropods from Greenland and the Baltic region

J. S. Peel.

The tremate condition in Salpingostoma and related bellerophontacean gastropods $\ldots \ldots \ldots \ldots \ldots \ldots, 72$

Bucania, Megalomphala and Salpingostoma ....... 72

The Tremanotus problem ................. 75

The tremate condition................... 77

Phragmolites, Conradella and Offleya .......... 79

Systematic conclusions.................. 80

Systematic palaeontology ................. 81

Genus Bucania Hall, $1847 \ldots \ldots \ldots \ldots \ldots \ldots \ldots, 81$

Bucania squamosa (Lindström, 1884). . . . . . . 81

Bucania stephnae sp. nov................... 85

Bucania groenlandica sp. nov. .............. 87

Genus Salpingostoma Roemer, $1876 \ldots \ldots \ldots \ldots \ldots \quad 89$

Salpingostoma megalostoma (Eichwald, 1840) . . . . 90

Salpingostoma martinssoni sp. nov. . . . . . . . 96 5 1

4

4

5

4

0

1

52
53
55
56
57
57
57
58
59
60
61

61

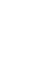




\section{Dansk sammendrag}

I nærværende arbejde beskrives en række bløddyr (Mollusca) fra Nedre Palæozoikum med udgangspunkt i en fortolkning af skallernes funktionelle morfologi. I forbindelse med nutidige diskussioner om oprindelsen af Mollusca omtales i introduktionen de nylige fund af halkieriider fra nederste Kambrium i Nordgrønland.

Den første afhandling omfatter bløddyr uden kropstorsion. Adskillelsen af klassen Helcionelloida fra klassen Tergomya på grundlag af skallens formodede orientering, da dyret var i live, danner basis for en ny fortolkning af den tidlige udvikling af Mollusca. Navnet Monoplacophora for klassen med bløddyr uden kropstorsion opgives.
I den anden afhandling beskrives bellerophontaceer (gastropoder) fra silure aflejringer i Nordgrønland og på Gotland, Sverige. Slægterne Salpingostoma og Megalomphala fortolkes på basis af originalmateriale fra Ordovicium i Estland, og deres morfologiske forhold til Bucania, Offleya og Phragmolites omdefineres. Der beskrives syv nye arter af Bucania, Salpingostoma og Megalomphala. Undersøgelsen viser, at udviklingen af en enkelt perforering (trema) i skallens dorsalvæg ikke alene er karakteristisk for slægten Salpingostoma men også findes i Bucania og Megalomphala.

\section{Imaqarnersiuineq}

Suliami matumani uumasut qituttut qaleruallit (Mollusca), soorlu uillut, siuteqqut il. il. Nedre Palæozoikum-ip nalaani uumasuusimasut qaleruaasa qanoq iluseqarnerat tunngavigalugu allaaserineqarput. Ullutsinni Molluscat qanga pinngorsimaneranik oqallinnermut atatillugu aallaqqaasiummi halkieriidit Avannaarsuani Kambriumip aallartinnerani uumasuusimasut qanittukkut siumorneqarsimasut allaaserineqarpoq.

Allaaserisami siullermi uumasut immikkoortut Hel- cionelloida aamma Tergomya uumagallaramik qaleruaasa sumut sammisimasinnaanerat tunngavigalugu immikkoortinniarneqarput. Allaaserinninneq Molluscat aallaqqaammut pileqqaaramik qanoq ineriartorsimanerannut nassuiaammi nutaami tunngavigineqarpoq.

Allaaserisap tulliani siuteqqut Avannaarsuani Sverigimilu kinnganerni Silurip nalaani uumasimasut eqqartorneqarput, allaaserinerannilu Estlandimi Ordoviciumip nalaani pinngoqqaartut tunngavigineqarlutik. 


\section{Introduction}

\section{Articulated halkieriids and microchitons}

There is widespread agreement at the present day that molluscs are descended from animals showing a similar level of organisation to the modern flatworms (see discussions in Runnegar \& Pojeta, 1985; SalviniPlawen, 1981, 1985; Wingstrand, 1985). The earliest molluscs were probably small spiculate worms with a radula and posterior gills, closely similar to extant Aplacophora (= Caudofoveata and Solenogastres of SalviniPlawen). Predecessors of the Aplacophora are postulated to have given rise to the Polyplacophora (= Placophora, the chitons) in which 8 dorsal valves are commonly surrounded by a mantle carrying minute calcareous spicules (cf. Smith, 1960), and ultimately to the shell-bearing Conchifera (Fig. 1).

Aplacophorans lack a fossil record and the earliest undisputed chitons appear near the Cambrian-Ordovician boundary (Runnegar et al., 1979; Runnegar \&
Pojeta, 1985; see also Yochelson, 1966, 1978, 1979). Older Cambrian faunas contain a wealth of mollusc and mollusc-like shells (e.g., Qian \& Bengtson, 1989; Missarzhevsky, 1989; Runnegar \& Jell, 1976; Runnegar \& Pojeta, 1985; Yu, 1987) but aplacophoran or polyplacophoran fossils have not been recognised. One Middle Cambrian problematic fossil, Wiwaxia corrugata (Matthew, 1899) from the Burgess Shale of Canada, contains a toothed feeding apparatus, possibly a radula, and may have been an early sclerite-covered mollusc (Conway Morris, 1985). Butterfield (1990) has recently suggested, however, that it may be a polychaete, reiterating an earlier opinion of Walcott (1911).

During the last decade fused associations of minute sclerites have been described from the earliest Cambrian of China and interpreted as microchitons ( $\mathrm{Yu}$, 1987, 1990). These have been seized upon as the missing
Fig. 1. Evolution of molluscan classes, modified from Wingstrand (1985). The tergomyan branch can be loosely equated with the Monoplacophora of many authors.

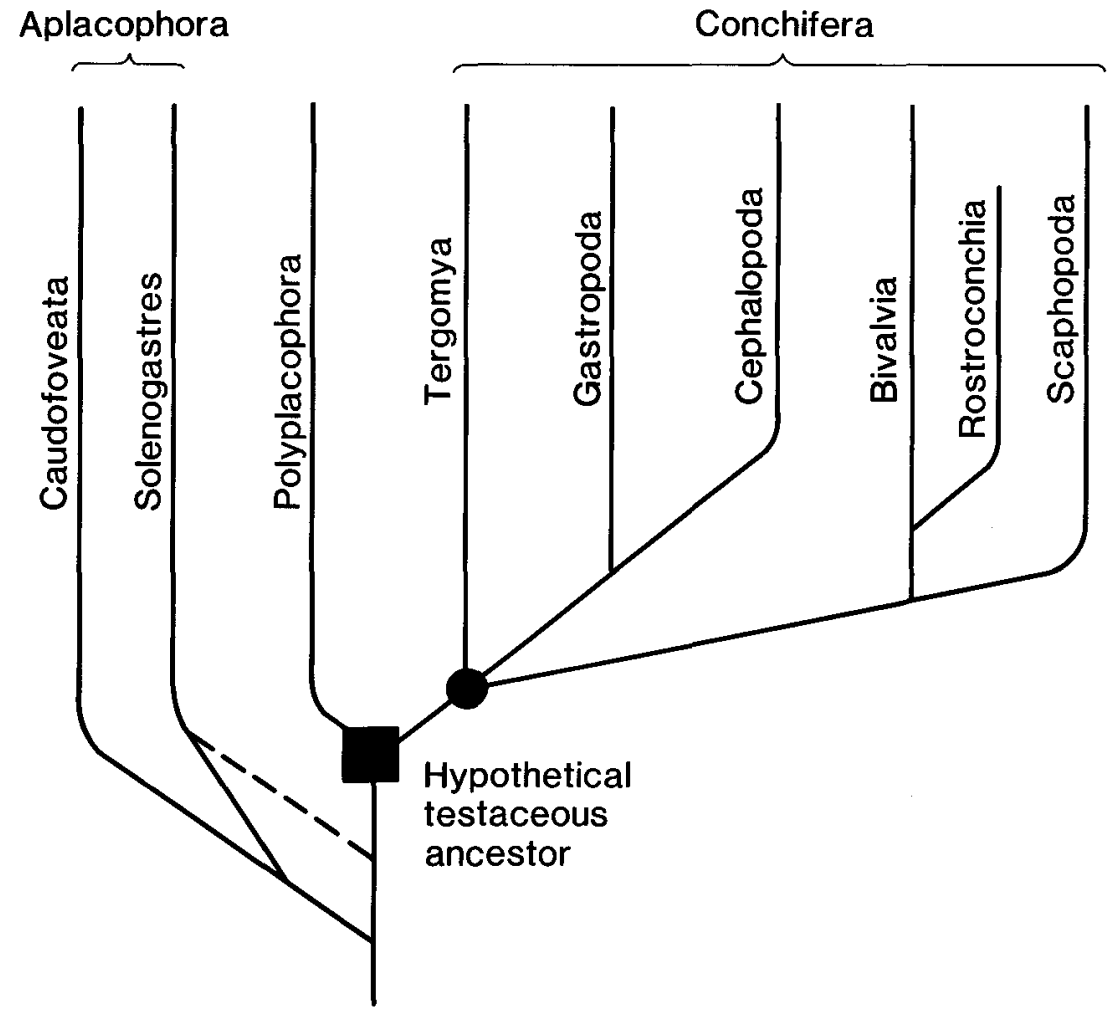




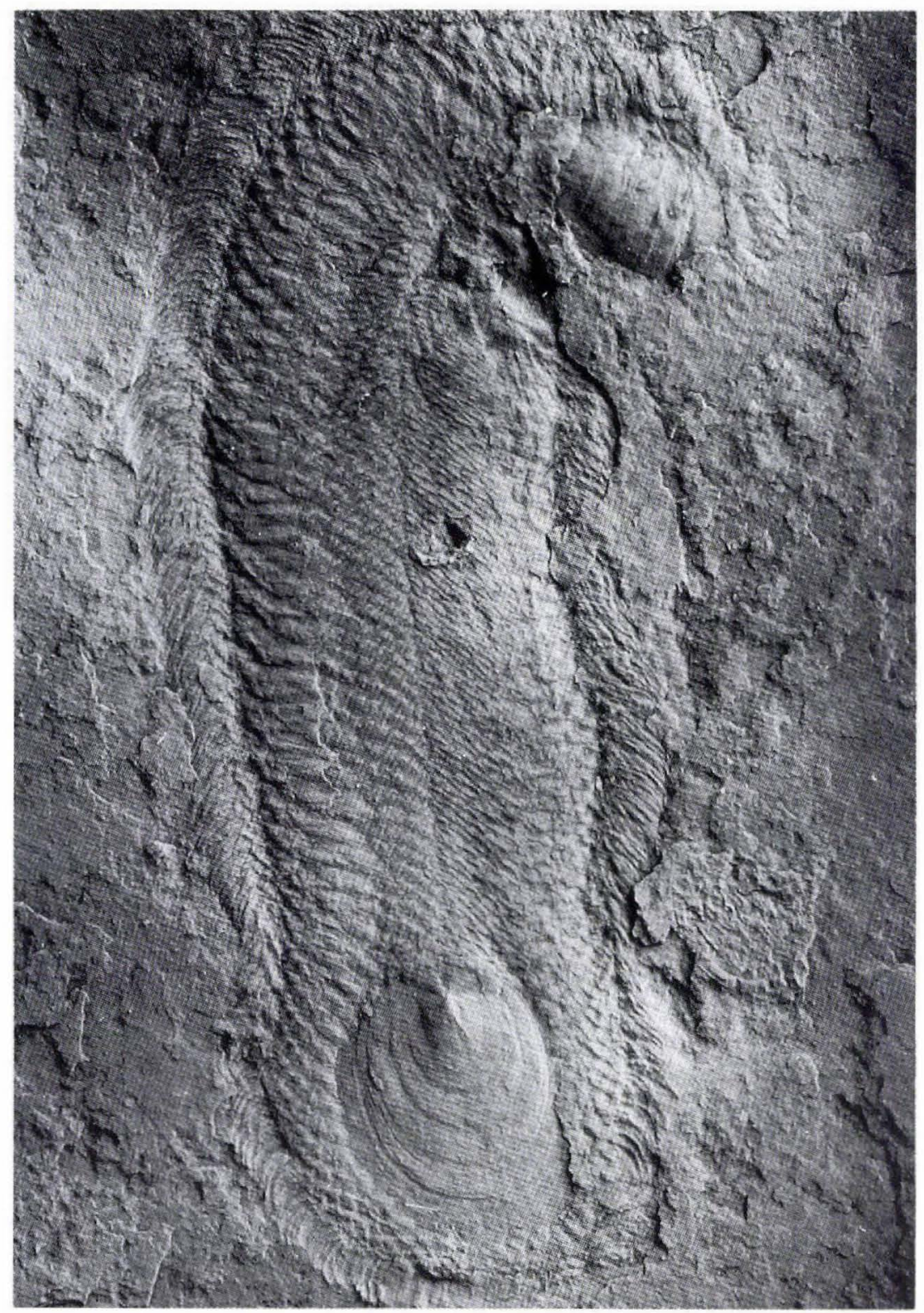

Fig. 2. Articulated halkieriid from the Buen Formation, Early Cambrian, of Sirius Passet, Peary Land, central North Greenland, MGUH 19.728 from GGU collection $340103, \times 2.7$. The anterior is turned to the right, obscuring some details of the anterior shell. Note the prominent posterior shell with an anterior apex and concentric growth lines indicating accretionary growth. Three zones of sclerites are present. The margins are rimmed by siculate sclerites which are delimited from the rest of the body by a lateral groove which is well seen on the left. Palmate sclerites in the axial area occur to either side of a median groove. A conspicuous zone of cultrate sclerites is present between the lateral groove and the zone of palmate sclerites.

early polyplacophoran-link in molluscan evolution (e.g. Haszprunar, 1988; Yu, 1990), though detailed morphological study has demonstrated that any resemblance to chitons is extremely superficial (Qian \& Bengtson, 1989). Thus, conclusive fossil evidence for the early differentiation of the Polyplacophora is still wanting.

The recent discovery of articulated halkieriids from the Lower Cambrian of North Greenland (Conway Morris \& Peel, 1990; see also Conway Morris et al., 1987 and Peel, 1990; Fig. 2) is significant on several counts. The articulated material conclusively demonstrates the organisation in the living animal of a number of small sclerites (originally described from the Cambrian of Bornholm, Denmark, under the name Halkieria Poulsen, 1967) which are frequently conspicuous as isolated fossils in Lower Cambrian collections. About 2000 of these sclerites are present in the scleritome. To a large extent, this juxtaposition of the spiny sclerites confirms earlier predictions (Bengtson \& Conway Morris, 1984) and can be compared with the distribution of the relatively larger, and numerically much fewer, sclerites in the Middle Cambrian Wiwaxia (Conway Morris, 1985).

Completely unexpected, however, is the occurrence 
in the halkieriid animal of two large shells, located one at each end of the armoured worm-like body. These shells superficially resemble molluscan shells, not the least on account of their accretionary growth which contrasts markedly with the secretion at a fixed size of the individual sclerites. A variety of grossly similar capshaped shells of problematic affinity is known from the Early Cambrian (cf. Qian \& Bengtson, 1989), although material identical with the anterior and posterior shells of the Greenland halkieriids does not appear to have been described.

Conway Morris (1985) suggested that Wiwaxia may be related to early molluses, and a similar interpretation of the articulated halkieriids from Greenland will no doubt prove attractive to many. The halkieriid specimens seem to combine the two skeletal elements that current models for early molluscan evolution require, namely a covering of spinose sclerites loosely analagous to the spicules of aplacophorans, and larger shells which may be compared to polyplacophoran valves. In addition, a mechanism for formation of the terminal shells is offered by reference to Early Cambrian cap-shaped shells such as Maikhanella Zhegallo, 1982, which appear to have formed from coalesced spinose sclerites (Missarzhevsky, 1989; Bengtson, 1990).

Other cap-shaped shells showing similar scaly struc- ture include Canopoconus Jiang, 1982 and Purella Missarzhevsky, 1974; their occurrence together with siphogonuchitid sclerites (Qian \& Bengtson, 1989) ultimately may allow reconstruction of additional scleritomes based on the halkieriid model.

It is clearly premature to interpret the halkieriid animal as a progenitor of Wingstand's (1985) 'hypothetical testacean ancestor' (Fig. 1) or as a morphological intermediary between aplacophorans and polyplacophorans on the basis of the first preliminary report, although a close relationship to the molluscs is a strong possibility (Conway Morris \& Peel, 1990). A radula-like feeding organ of the type described in Wiwaxia by Conway Morris (1985) has not been recognised. Neither is the function of the anterior and posterior plates elucidated; they bear little morphological resemblance in detail to known polyplacophoran valves or indeed to other molluscan shells.

Bengtson (1990) suggested that the terminal plates in the halkieriid animal may have served to protect the entrances of a U-shaped burrow occupied by the halkieriid worm. It is also possible that the anterior valve may have offered increased protection to the head region of the active worm while the larger posterior shell could have roofed a rudimentary mantle cavity containing respiratory organs located around the anus.
Fig. 3. Untorted univalved molluscs (referred to the Class Tergomya by Peel. $1991 \mathrm{~b}$ in this volume) representing a major lineage within the now abandoned Class Monoplacophora. A, B, Tryblidium reticulatum Lindström, 1880, Silurian, Högklint Formation, Gotland, Sweden, MGUH 16.469 , in dorsal and lateral (with the apex to the left) views, $\times 3.5$. C, Pilina cheyennica Peel, 1977, internal mould showing the serially arranged muscle scars on the dorsum. Late Ordovician Chimneyhill Limestone, Oklahoma, U. S. A., YPM 74, holotype, $\times 1.5$.

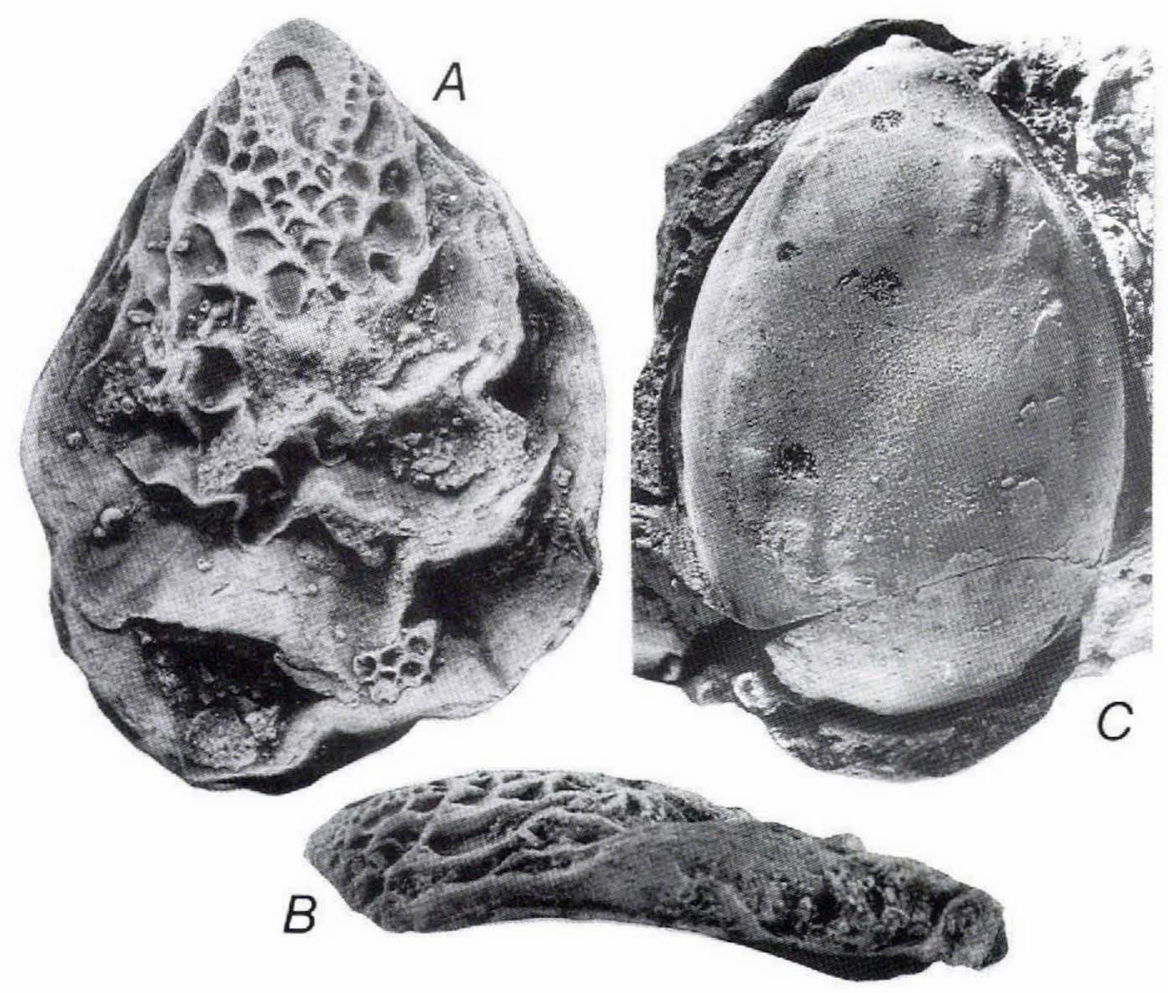


Fig. 4. Helcionelloids from the Cambrian of North Greenland. A, Latouchella holmdalense Peel, 1988, MGUH 18.681 from GGU collection 225535, $\times 10 . \mathrm{B}$, Eotebenna arctica Peel, 1989, MGUH 18.701 from GGU collection $315109, \times 7 . \mathrm{C}$, Perssuakiella troelseni Peel, 1988, MGUH 18.687 from GGU collection $225537, \times 15$.
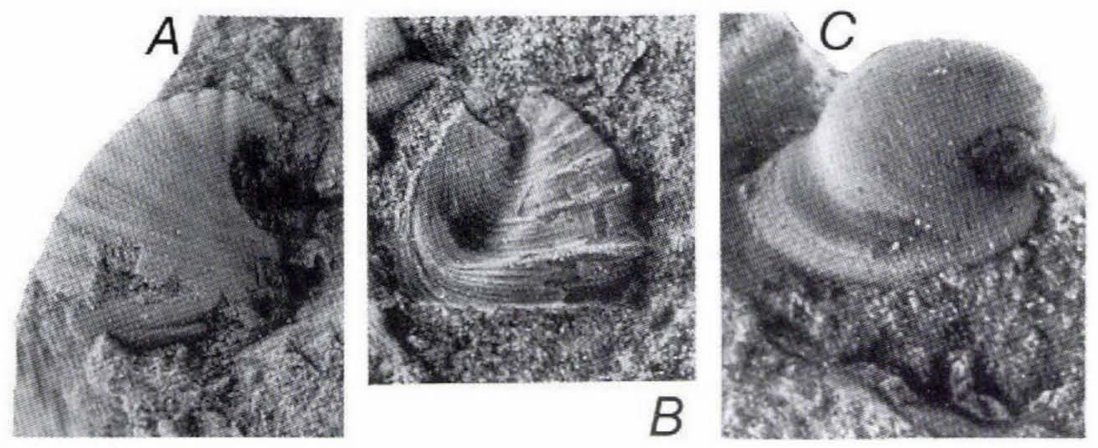

The Greenland halkieriids provide an invaluable templet for the reconstruction of many other Early Cambrian metazoans currently known only from their scattered constituent skeletal elements. Their discovery will inevitably stimulate future search for ancestral molluscs within the Cambrian fossil record. However, the unexpected association of terminal shells and spinose sclerites also offers a warning to human speculation, stressing the need for "... a combination of vivid imagination, scrupulous pedantry and deep humility" (Bengtson, 1990, p. 766) if we are to successfully unravel Nature's complexity.

The molluses described in the two papers in this volume are descendants of the "hypothetical testaceous ancestor' in Wingstrand's (1985) diagram (Fig. 1). All of them have been placed within the Class Monoplacophora by some recent authors (e.g., Runnegar \& Pojeta, 1974, 1985; Pojeta \& Runnegar, 1976; Runnegar \& Jell, 1976). Knight \& Yochelson (1960) in the Treatise on Invertebrate Paleontology noted that this molluscan taxon described by Knight (1952) was characterised by a general bilateral symmetry, with pairing of the gills, shell-attachment muscles and other anatomical structures, a single dorsal shell and the absence of the process of torsion which is characteristic of the gastropods. The concept is based around rare, and only recently discovered living species assigned to the genus Neopilina Lemche, 1957 and similar fossils, including the Ordovician-Silurian genus Tryblidium Lindström, 1880 and Pilina Koken \& Perner, 1925 (Fig. 3), known for more than a century but generally assumed to be gastropods (interestingly, the concept was established on the basis of fossil material and confirmed some few years later with the description of the living specimens, see Knight, 1952; Lemche, 1957; Lemche \& Wingstrand, 1959; Wingstrand, 1985).

In recent years the content of the Class Monoplacophora has been extended significantly to include a wide variety of presumed untorted, fossil, univalved molluscs (cf. Runnegar \& Pojeta, 1974, 1985; Runnegar \& Jell, 1976) many of which have been assigned to other molluscan classes by other workers.

It is the main thesis of the first paper in this volume (Peel, 1991b) that the Class Monoplacophora should be abandoned and that two principal classes of untorted
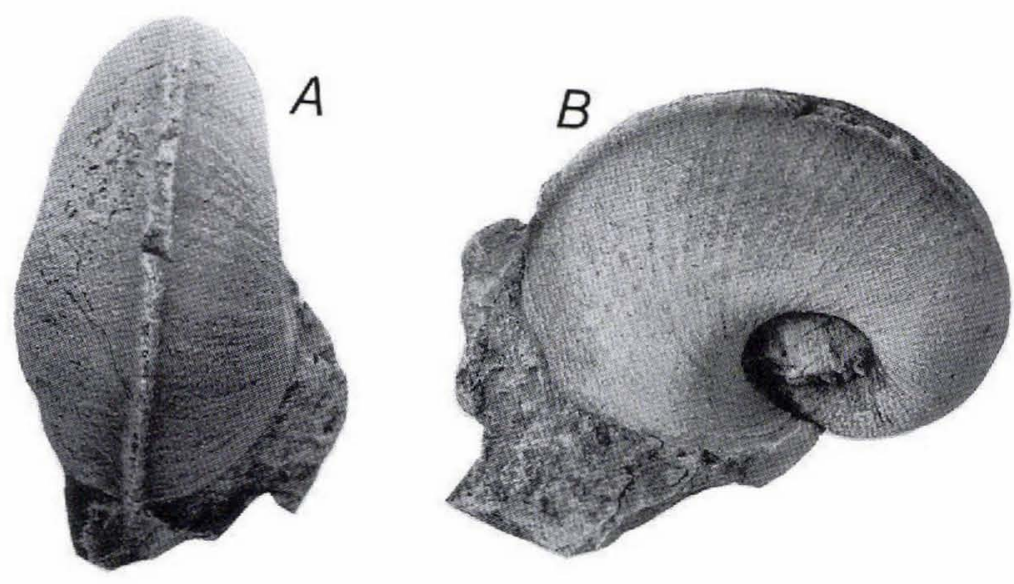

Fig. 5. Bucania groenlandica sp. nov., a bellerophontacean gastropod described by Peel (1991c, fig. $18 \mathrm{D}-\mathrm{F}$ ) in this volume from the Silurian Washington Land Group of North Greenland. MGUH 20.842 from GGU collection 301319, × 1.33. A, dorsal view showing the narrow slit (below) which generates a selenizone forming the upper surface of the median dorsal keel; the slit is a characteristic feature of most bellerophontacean gastropods. B, oblique lateral view showing the sediment-filled umbilicus; anterior is to the left. 
univalved molluses should be recognised (other classes, less conspicuous in the fossil record, also exist but are only briefly mentioned in the present context). These two classes were given the names Tergomya and Helcionelloida by Peel (1991a) and their establishment follows functional morphological interpretation of a variety of apertural features in the Helcionelloida. The Tergomya includes Neopilina and its close relatives in which the shell apex lies anteriorly (Fig. 3), whereas members of the Class Helcionelloida are characterised by a univalve shell with the apex at the posterior (Fig. 4).

A functional morphological approach is also followed in the second paper (Peel, 1991c) where structural modification of the median dorsal slit is discussed in a group of Ordovician-Silurian bellerophontacean gastropods related to the genera Bucania Hall, 1847, Megalomphala Ulrich in Ulrich \& Scofield, 1897 and Salpingostoma Roemer, 1876 (Fig. 5). Bellerophontacean gastropods are conspicuous in the Palaeozoic and are distinguished from most other members of the class by being coiled symmetrically within a single plane. This symmetry is a central argument in the thesis of some authors (including Runnegar \& Pojeta, 1974, 1985) that members of the group were not gastropods (i.e. torted molluscs) but untorted molluscs. Some bellerophontiform molluscs do appear to have been untorted (and as such are referred to the Order Cyrtonellida of the Class Tergomya by Peel 1991b) but most others, including the genera and species described herein from Greenland and the Baltic region, are considered to be gastropods.

Acknowledgements. GGU denotes collections of Grønlands Geologiske Undersøgelse, the Geological Survey of Greenland, Copenhagen; MGUH and YPM indicate specimens in the type collections of the Geological Museum, University of Copenhagen, and Yale Peabody Museum, New Haven, Connecticut, respectively.

\section{References}

Bengtson, S. 1990: The solution to a jigsaw puzzle. Nature 345, 765-766.

Bengtson, S. \& Conway Morris, S. 1984: A comparative study of Lower Cambrian Halkieria and Middle Cambrian Wiwaxia. Lethaia 17, 307-329.

Butterfield, N. J. 1990: A reassessment of the enigmatic Burgess Shale fossil Wiwaxia corrugata (Matthew) and its relationship to the polychaete Canadia spinosa Walcott. Paleobiology 16, 287-303.

Conway Morris, S. 1985: The Middle Cambrian metazoan Wiwaxia corrugata (Matthew) from the Burgess Shale and Ogygopsis Shale, British Columbia. Phil. Trans. R. Soc. London B307, 507-586.
Conway Morris, S. \& Peel, J. S. 1990: Articulated halkieriids from the Lower Cambrian of north Greenland. Nature 345, 802-805.

Conway Morris, S., Peel, J. S., Higgins, A. K., Soper, N. J. \& Davis, N. C. 1987: A Burgess shale-like fauna from the Lower Cambrian of North Greenland. Nature 326, 181-183.

Haszprunar, G. 1988: On the origin and evolution of major gastropod groups, with special reference to the Streptoneura. Jour. Molluscan Stud. 54, 367-441.

Knight, J. B. 1952: Primitive fossil gastropods and their bearing on gastropod classification. Smithson. Misc. Colls 114 (13), 1-55.

Knight, J. B., \& Yochelson, E. L. 1960: Monoplacophora. In Moore, R. C. (ed.) Treatise on invertebrate paleontology, I, Mollusca 1, I77-I84. Lawrence: Univ. Kansas Press and Geol. Soc. Am.

Lemche, H. 1957: A new living deep-sea mollusc of the Cambro-Devonian Class Monoplacophora. Nature 179, 413-416.

Lemche, H. \& Wingstrand, K. G. 1959: The anatomy of Neopilina galatheae Lemche, 1957. Galathea Rept 3, 9-71.

Missarzhevsky, V. V. 1989: [Oldest skeletal fossils and stratigraphy of Precambrian and Cambrian boundary beds]. Trudy Ordena Trydov. Kras. Zhameni geol. Inst. Akad. Nauk SSSR 443, 237 pp. [in Russian].

Peel, J. S. 1990: Studying the early history of life in Greenland. Rapp. Grønlands geol. Unders. 148, 54-56.

Peel, J. S. 1991a: Functional morphology of the Class Helcionelloida nov., and the early evolution of the Mollusca. In Simonetta, A. \& Conway Morris, S. (ed.) The early evolution of Metazoa and the significance of problematic taxa, 157-177. Cambridge: Cambridge Univ. Press and Univ. Camerino.

Peel, J. S. 1991b: The Classes Tergomya and Helcionelloida, and early molluscan evolution. Bull. Grønlands geol. Unders. 161 (this volume).

Peel, J. S. 1991c: Salpingostomatiform and related bellerophontacean gastropods from Greenland and the Baltic region. Bull. Gronlands geol. Unders. 161 (this volume).

Pojeta, J., Jr., \& Runnegar, B. 1976: The paleontology of rostroconch molluscs and the early history of the Phylum Mollusca. [U. S.] geol. Surv. Prof. Pap. 968, 88 pp.

Qian Yi \& Bengtson, S. 1989: Palaeontology and biostratigraphy of the Early Cambrian Meishucunian Stage in Yunnan Province, South China. Fossils and Strata 24, 156 pp.

Runnegar, B., \& Jell, P. A. 1976: Australian Middle Cambrian molluscs and their bearing on early molluscan evolution. Alcheringa 1, 109-138.

Runnegar, B., \& Pojeta, J., Jr. 1974: Molluscan phylogeny: the paleontological viewpoint. Science 186, 311-317.

Runnegar, B., \& Pojeta, J., Jr. 1985: Origin and diversification of the Mollusca. In Trueman, E. R. \& Clarke, M. R. (ed.) The Mollusca 10, Evolution, 1-57. Orlando: Academic Press.

Runnegar, B., Pojeta, J., Taylor, M. E. \& Collins, D. 1979: New species of the Cambrian and Ordovician chitons Matthevia and Chelodes from Wisconsin and Queensland: evidence for the early history of polyplacophoran mollusks. Jour. Paleont. 53, 1374-1394. 
Salvini-Plawen, L. von 1981: On the origin and evolution of the Mollusca. Origine dei grandi Phyla dei Metazoi, Atti dei Convegni Lincei, Accad. Naz. dei Lincei 49, 235-293.

Salvini-Plawen, L. von 1985: Early evolution and the primitive groups. In Trueman, E. R. \& Clarke, M. R. (ed.) The Mollusca 10, Evolution, 59-150. Orlando: Academic Press.

Smith, A. G. 1960: Amphineura. In Moore, R. C. (ed.) Treatise on invertebrate paleontology, I, Mollusca 1, I41-176, Lawrence: Univ. Kansas Press and Geol. Soc. Am.

Walcott, C. D. 1911: Middle Cambrian annelids. Smithson. Misc. Colls 57, 109-144.

Wingstrand, K. G. 1985: On the anatomy and relationships of Recent Monoplacophora. Galathaea Rept 16, 7-94.

Yochelson, E. L. 1966: Mattheva, a proposed new class of mollusks. [U. S.] geol. Surv. Prof. Pap. 522-B, 11 pp.

Yochelson, E. L. 1978: An alternative approach to the interpretation of the phylogeny of ancient mollusks. Malacologia 17, 165-191.
Yochelson, E. L. 1979: Early radiation of Mollusca and mollusc-like groups. In House, M. R. (ed.) The origin of the major invertebrate groups, 323-358. New York: Academic Press.

Yu Wen 1987: Yangtze micromolluscan fauna in Yangtze Region of China, with notes on Precambrian-Cambrian boundary. Stratigraphy and palaeontology of systematic boundaries in China. Precambrian-Cambrian Boundary (1), 19-344. Nanjing: Nanjing Univ. Publ. House.

Yu Wen 1991: The first radiation of shelled molluscs. Paleontologia cathayana 5, 139-170.

John S. Peel, June 1991. 


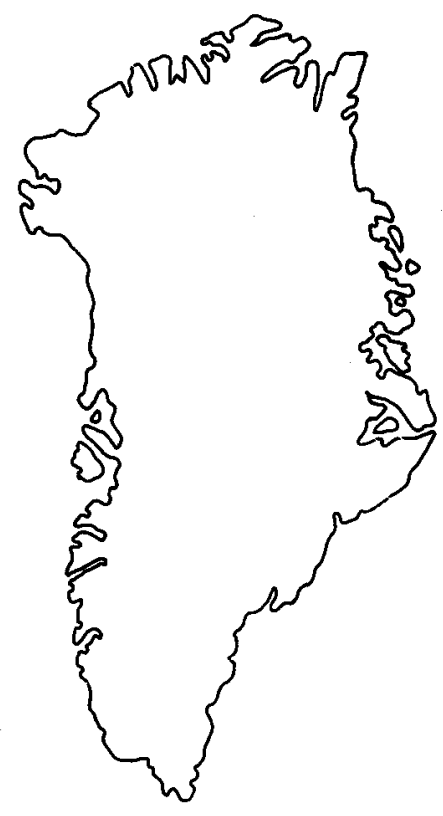

\title{
The Classes Tergomya and Helcionelloida, and early molluscan evolution
}

\author{
John S. Peel
}

The broad spectrum of shell morphologies assigned to the molluscan Class Monoplacophora, and widespread inconsistency in application, have motivated abandonment of the term in formal systematics. Two classes, Tergomya and Helcionelloida, are recognised to include two of the major groups of untorted molluscs formerly united within the Monoplacophora by some recent authors.

The concept behind recognition of the Classes Tergomya and Helcionelloida is examined from the point of view of functional morphology. In the exogastric Tergomya, which includes the present day Neopilina Lemche, 1957 and its relatives, the apex of the generally low, cap-shaped shell is located anteriorly and the shell expands towards the posterior. More specialised tergomyans include tall hypseloconellaceans and strongly coiled cyrtonellaceans. Three orders are recognised: Tryblidiida, Cyrtonellida and Hypseloconida (nov.). The Class Helcionelloida includes endogastrically coiled shells in which the apex lies at the posterior and the shell expands anteriorly. Helcionelloids are probably ancestral to the Classes Rostroconchia and Scaphopoda, and may have given rise to the first cephalopods.

Recognition of Tergomya and Helcionelloida suggests that the Sub-phyla Diasoma and Cyrtosoma of recent authors may be polyphyletic; their use is discontinued.

Models for the evolution of the molluscs are discussed from the point of view of the early fossil record.

J. S. P., Geological Survey of Greenland, $\emptyset_{\text {ster Voldgade 10, DK-1350 Copenhagen }}$ $K$, Denmark.

The definition of the Monoplacophora by Knight (1952), on the basis of a suite of Palaeozoic fossils, in many ways acknowledged the expectation of molluscan workers for almost a century by establishing a taxon approximating to the 'archimollusc', the theoretical ancestor of the other shelled Mollusca favoured by many workers (cf. Morton, 1979, p. 12; Pojeta, 1980; see also Salvini-Plawen, 1980, 1981, 1985). Discovery of the living monoplacophoran Neopilina Lemche, 1957 placed Knight's description on a firm footing, adding detailed anatomical knowledge to a fossil group presumed extinct since the Devonian (Lemche, 1957; Lemche \& Wingstrand, 1959; Wingstrand, 1985). Not surprisingly, the last three decades have seen considerable activity in the study of molluscan evolution, with the untorted, univalved molluscs referred to the Class Monoplacophora figuring prominently in theoretical studies, and with an ever increasing total of fossil monoplacophorans being described. As with most rapidly developing scientific fields, the study of fossil monoplacophorans has taken many twists and turns, with frequent new discoveries, and with conflicting views emerging concerning the scope of the class within the available fossil record.

\section{Monoplacophora: historical usage}

Monoplacophorans were first described as fossils more than a century ago, but their significance was not at that time appreciated. Specimens from the Silurian of Gotland, Sweden, described by Lindström (1884) remain some of the best known and best preserved taxa, figuring prominently both in palaeontological studies (e.g., Knight, 1952; Knight \& Yochelson, 1960; Peel, 1977a) and in the study of living forms by Lemche (1957) and Lemche \& Wingstrand (1959). It is appropriate that Lemche (1957) derived the name of Neopilina from one of these Gotland forms, Tryblidium unguis Lindström, 1880, which Koken \& Perner (1925) had earlier made type species of the new genus Pilina (Fig. 1).

Lindström (1884) described Pilina unguis and the contemporary Tryblidium reticulatum Lindström, 1880 as patelliform gastropods, noting the similarity of the multiple paired muscles of the two Gotland species with some specimens of extant patelliform gastropods in which the normally continuous muscle scar on the shell interior is broken into segments (Lindström, 1884, pl. 1, 

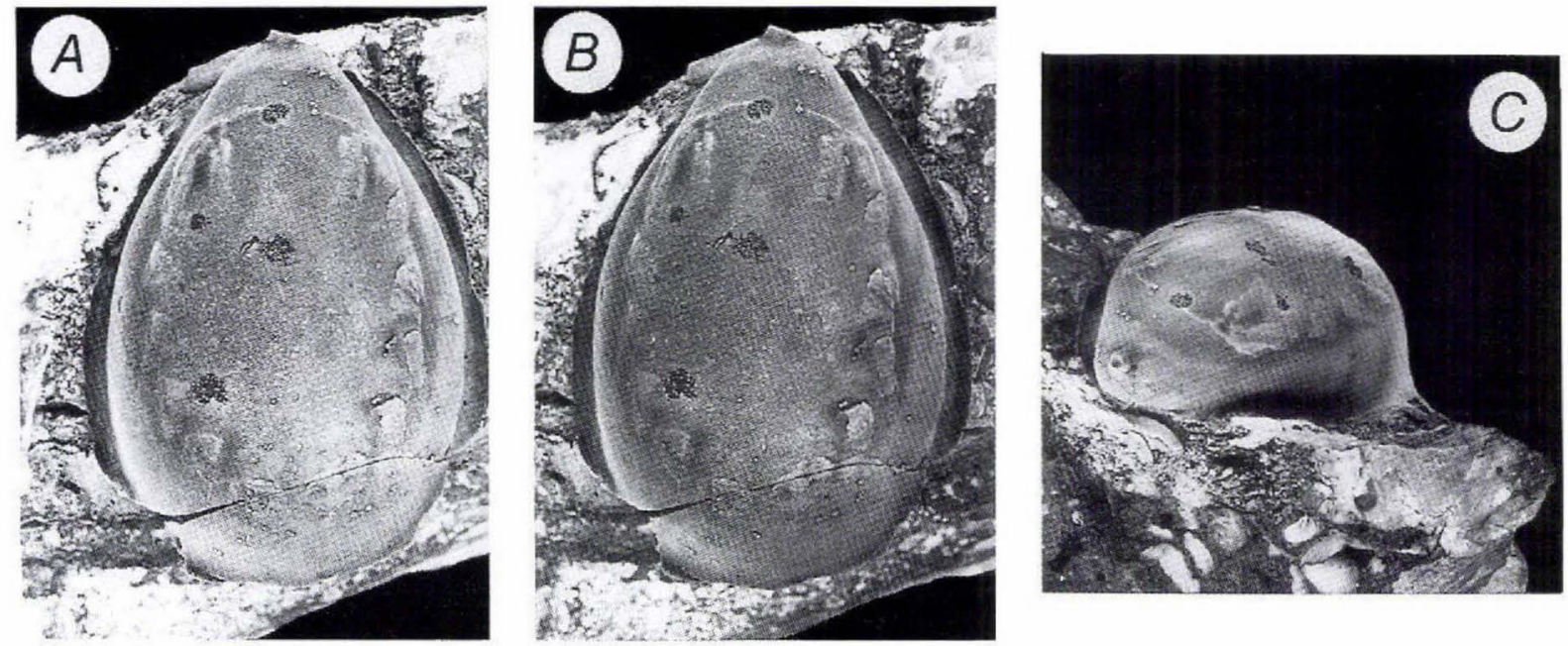

Fig. 1. Pilina cheyennica Peel, 1977, from the Late Ordovician Chimneyhill Limestone, near Ada, Oklahoma, U.S.A., YPM 74, holotype. A, B, stereo-pair of internal mould of a tryblidiacean tergomyan in dorsal view, oriented with anterior at the top and showing the paired, raised muscle scars; the small anterior tubercle represents the earliest growth stages, $\times 1.3$. C, oblique anterior view, $\times 1$. Note the external moulds of small bryozoan colonies which encrusted the interior of the dead shell.

fig. 32). Lindström's descriptions clearly indicated the essential shell characteristics of these 'original' mono-

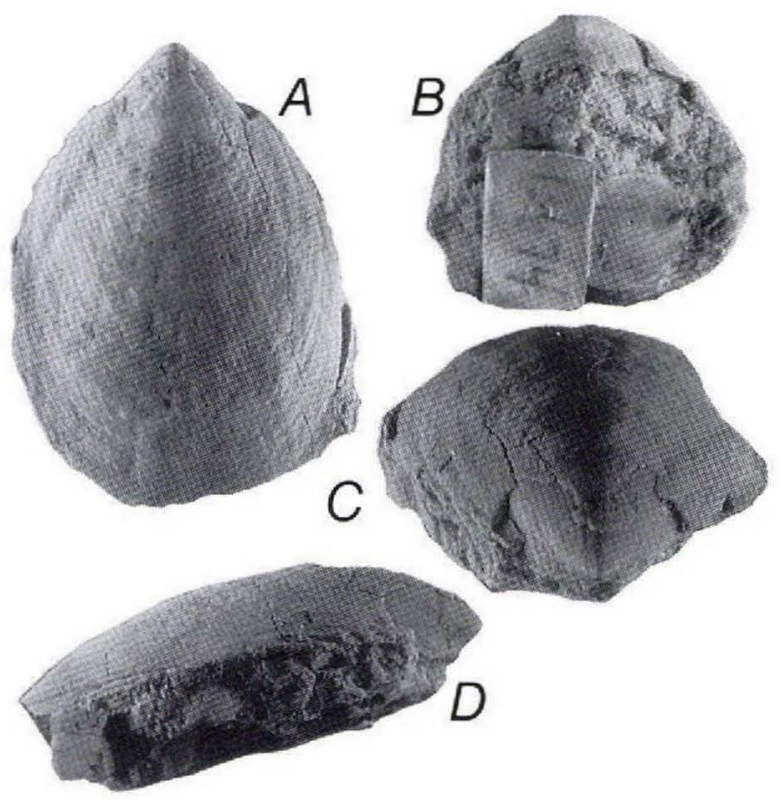

Fig. 2. Tryblidium arcticum Poulsen, 1974, a tryblidiacean tergomyan from the early Silurian of Washington Land, western North Greenland, MMH 13.674, holotype, × 1. A, dorsal view. B, apico-ventral view showing the concave sub-apical surface below the overhanging apex. C, apico-dorsal view. D, lateral view showing the concave apertural plane with the resultant lateral emargination interpreted as the locus of the inhalant stream. placophorans: the univalve, bilaterally symmetrical shell with the apex located near to the margin and the series of paired muscle scars on the shell interior, usually preserved as paired elevations on moulds of the shell interior (cf. Peel, 1977a and Figs 1,2). Study of living Neopilina indicates that the monoplacophoran apex lies anteriorly and the shell thus expands towards the rear, i.e. the shell is exogastrically coiled. The anteriormost pair of muscles are large and composite, while subsequent pairs of muscles are subequal in size.

Lindström (1884) coined the term Tryblidia in referring collectively to various species resembling the Gotland forms and these monoplacophorans are usually placed within an Order Tryblidiida Lemche, 1957; they are frequently referred to as tryblidiaceans, tryblidians etc.

Wenz (1940) introduced the term Monoplacophora as an informal name for the tryblidiaceans to contrast their univalved shell with the multivalved shell of the Polyplacophora (cf. Geyer, 1986).

Knight (1952, p. 45) formally recognised the Monoplacophora as an order within the Sub-class Isopleura of an embracive Class Gastropoda. As the name suggests, the Isopleura retained "both in the shell and in the soft anatomy the primitive bilateral symmetry of the class." In addition to the Monoplacophora, Knight recognised the Polyplacophora (chitons) and Aplacophora as orders within the Isopleura, while the Sub-class Anisopleura contained the torted 'gastropods' which comprise the Class Gastropoda of current usage.

Knight (1952) established three families within the 
Fig. 3. Archinacella(?) cf. A.(?) elongata (Cullison, 1944) from the Early Ordovician Poulsen Cliff Formation, Washington Land, western North Greenland, MGUH 18.970 from GGU collection 206483, $\times 4$. This supposed gastropod is shown in oblique dorso-lateral view (A), in dorsal view with the posterior apex located uppermost in the illustration (B), in oblique apico-dorsal view (C) and in lateral view with the strongly coiled apex overhanging the posterior margin (D).
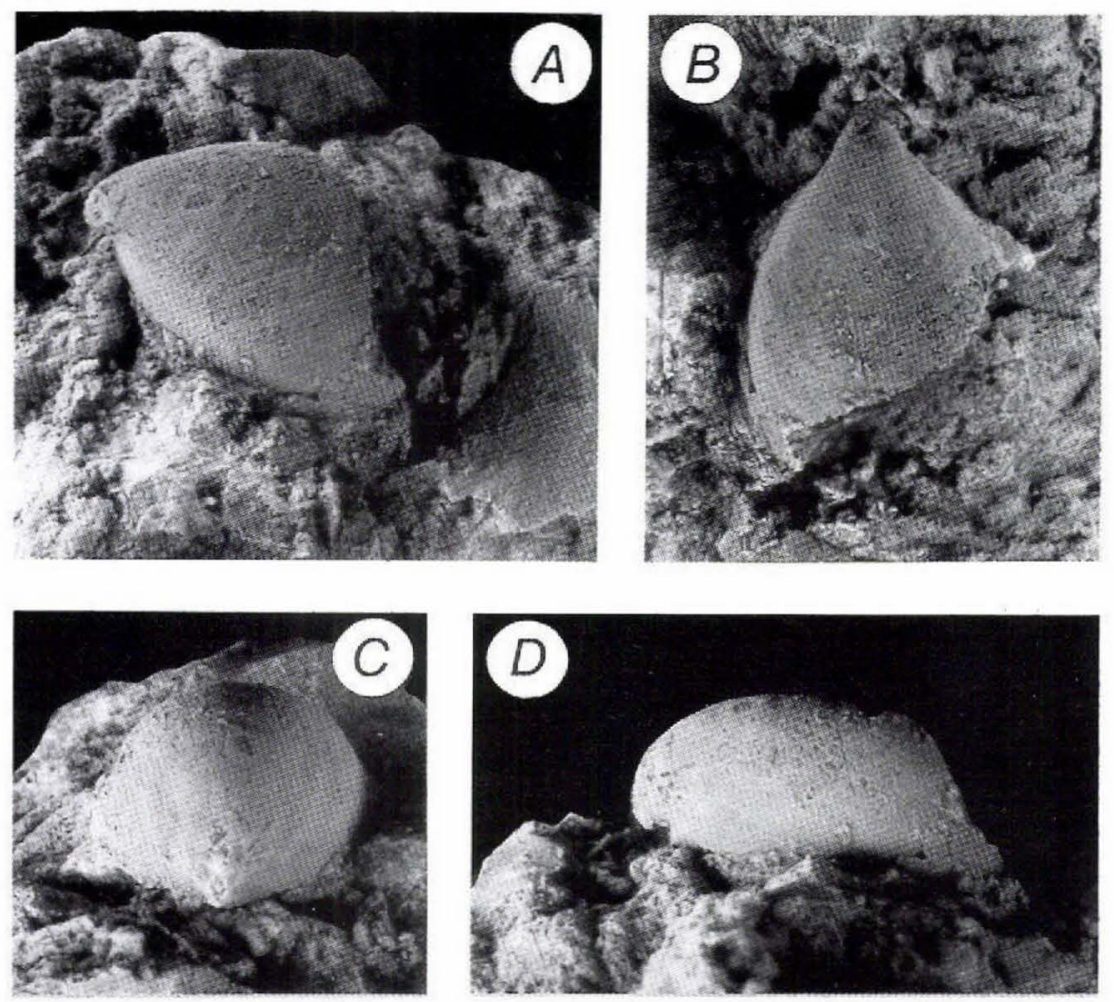

Monoplacophora, namely Tryblidiidae, Hypseloconidae and Archinacellidae.

In the Treatise on Invertebrate Paleontology Knight \& Yochelson (1960) included within the Class Monoplacophora three orders which many workers now assign to three distinct classes of Mollusca. Most genera within their Order Tryblidioidea (= Tryblidiida) are what might be termed 'traditional monoplacophorans' such as Pilina and Tryblidium (Figs 1,2). Their archinacelloideans (= Archinacellida; Fig. 3) are gastropods according to Starobogatov (1970), Harper \& Rollins (1982), Yochelson (1988) and Peel (1990a), with Harper \& Rollins also placing the cyrtonellacean tryblidioideans of Knight \& Yochelson (1960) in this class. Members of
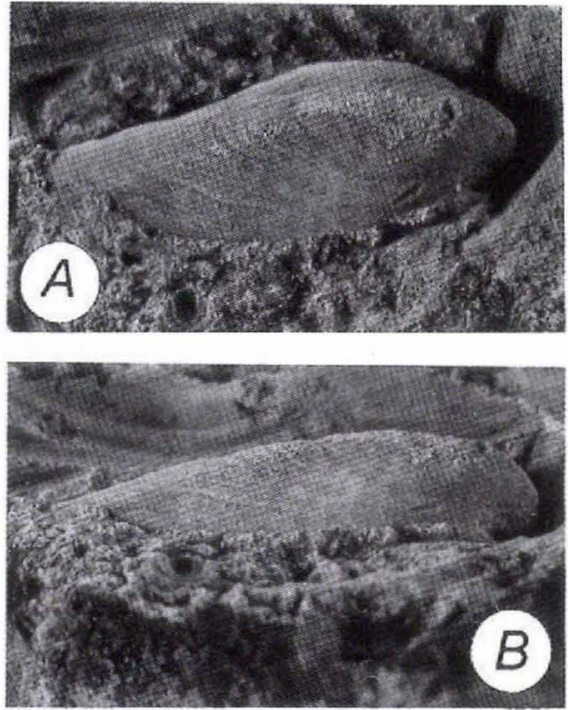

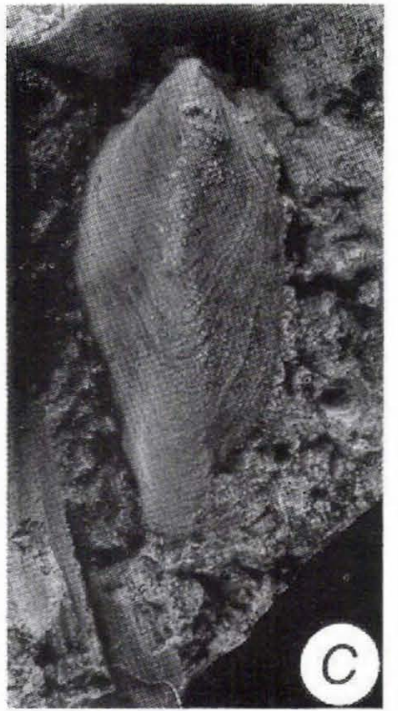

Fig. 4. Stenothecoides groenlandicus Peel, 1988 from the late Middle Cambrian Holm Dal Formation, Peary Land, central North Greenland, MGUH 18.676 from GGU collection $225561, \times 6$. Oblique-lateral, lateral and plan views of a possible right valve. 


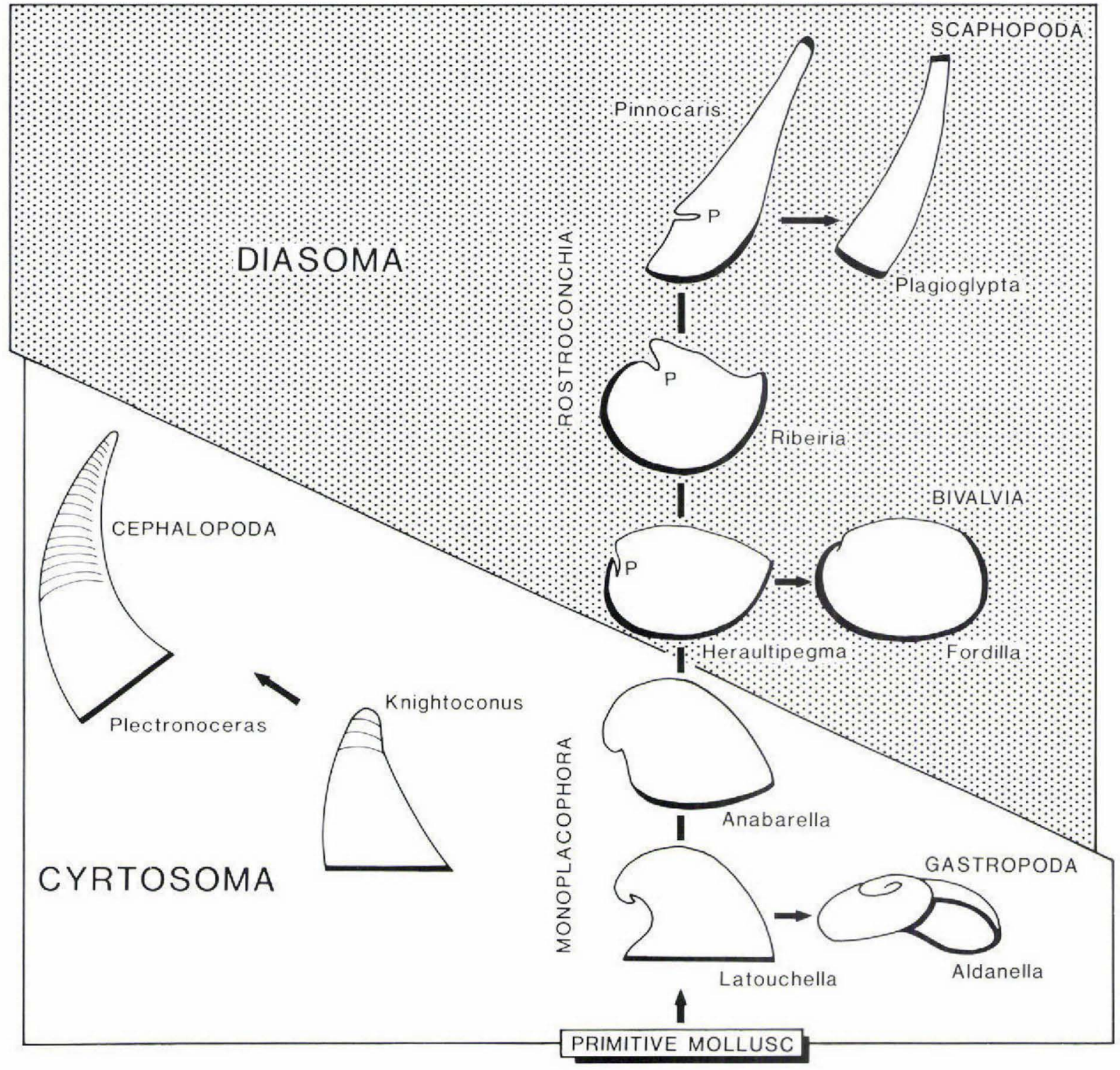

Fig. 5. Origin of the univalved and bivalved molluscs according to Runnegar \& Pojeta (1974). Classes forming the Sub-phylum Diasoma (Rostroconchia, Bivalvia and Scaphopoda) are derived from the Class Monoplacophora. The Sub-phylum Cyrtosoma consists of the classes Monoplacophora, Gastropoda and Cephalopoda. Open apertures are indicated by thick black lines; p, pegma (redrawn from Runnegar \& Pojeta, 1974, fig. 4). Runnegar \& Pojeta (1974) considered the monoplacophorans Latouchella and Anabarella to be coiled exogastrically, i.e., with the shell coiled clock-wise when viewed laterally with anterior to the left as illustrated, while Knightoconus and its descendant cephalopods are endogastric, coiling anti-clockwise with the anterior to the left (ef. Fig. 12). In the present paper Latouchella and Anabarella are considered to be endogastric with the anterior to the right, as illustrated, while Knightoconus is interpreted as pseudo-endogastric, with the anterior to the left.

the Order Cambridioidea belong to the Class Stenothecoida (Fig. 4).

Horny $(1965 a, b)$, in part of a prolific series of papers concerning fossil monoplacophorans, proposed two sub-classes within the Monoplacophora, one of which (Sub-class Tergomya) corresponds to the traditionally recognised tryblidiacean lineage. The Sub-class Cyclomya included the archinacelloideans and the more strongly coiled cyrtonellacean tryblidioideans of Knight \& Yochelson (1960). In the Tergomya, muscle scars form a ring located posterior to the shell apex, such that the apex lies outside of the muscle field, as in Pilina 

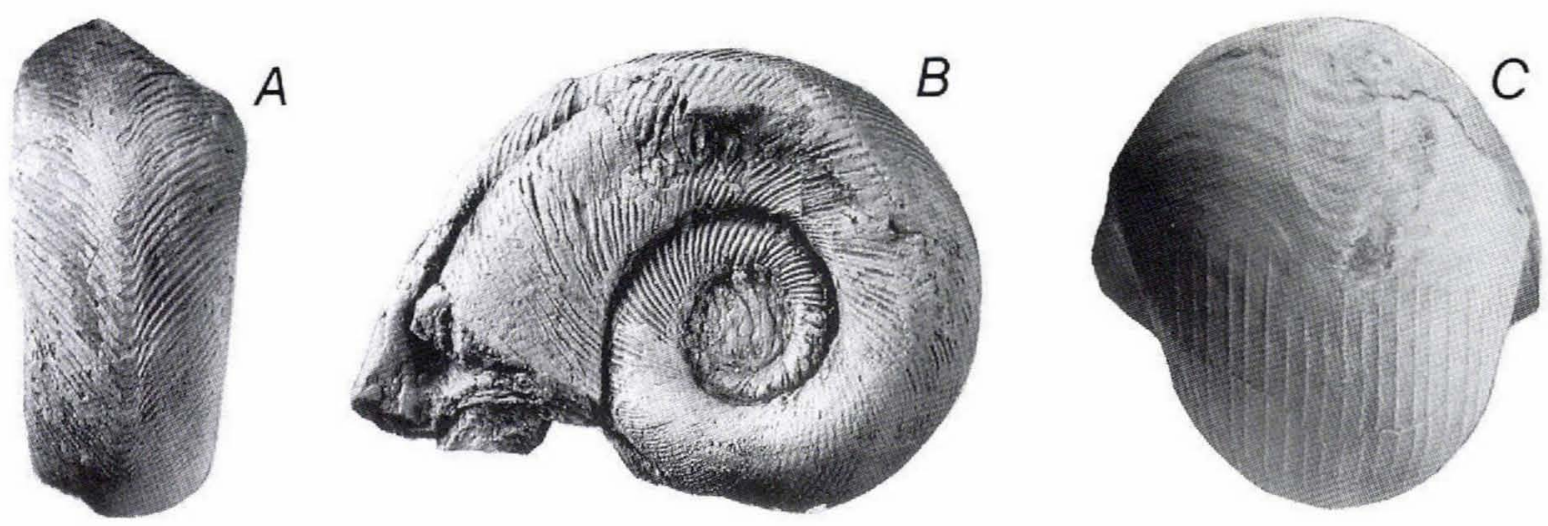

Fig. 6. Bellerophontiform molluscs. A, B, Modestospira poulseni Yochelson, 1964 from the Lower Ordovician Orthoceras Limestone of Store Duegaard, Bornholm, Denmark. Holotype, MMH 9.953, $\times 2$, in dorsal and lateral views. Modestospira is characterised by its loosely coiled whorls, wide umbilici (B) and the median dorsal sinus (A). C, Euphemites jacksoni (Weir, 1931) from the Carboniferous (Namurian) of Congleton Edge, Cheshire, U.K. Topotype, MGUH 16.783, $\times 4$. In this globose bellerophontacean a broad slit generates a selenizone which, atypically for the group, is only visible in the latest part of the whorl due to the deposition of a strongly ribbed outer shell layer. In Plectonotus (Fig. 25A) this outer shell layer is not present and the selenizone is visible throughout the final whorl.

(Fig. 1; see also Fig. 13 and discussion below). In cyclomyans, which are often more strongly coiled, the shell apex lies within the muscle field.

The model of molluscan evolution presented by Runnegar \& Pojeta (1974) and developed in a subsequent series of papers (e.g. Pojeta, 1980; Pojeta \& Runnegar, 1976; Runnegar, 1978, 1983; Runnegar \& Jell, 1976; Runnegar \& Pojeta, 1985) depended largely on the adoption of a wide concept for the Class Monoplacophora which forms the stem-group for the other major taxa (Fig. 5) "thus expanding the original concept of the class to embrace most or all stem group molluses that possessed an undivided shell (Conchifera)" (Runnegar in Bengtson et al., 1990, p. 233). Apart from tryblidiaceans such as Pilina, Tryblidium and Neopilina, Runnegar \& Pojeta (1985) formally assigned the helcionellids, hypseloconids, bellerophontids, archinacellids, pelagiellids, tuarangiids and cyrtonellids to the class.

The Class Stenothecoida of Yochelson (1968, 1969, 1978) and Aksarina (1968; under the name Probivalvia; cf. Fig. 4), was dismissed by Runnegar \& Pojeta (1974) as a group of bivalved monoplacophorans, without formal placement. Pojeta \& Runnegar (1976, fig. 14) seemingly accept the class, but its constituent members are not included within the classifications given by Runnegar (1983) or Runnegar \& Pojeta (1985).

One aspect of this large-scale expansion of the concept of the Class Monoplacophora, the assumption that all bellerophontiform molluscs (i.e. those strongly coiled, bilaterally symmetrical molluscs which morph- ologically resemble the genus Bellerophon de Montfort, 1808; Fig. 6) were untorted, has lead to protracted debate in the literature. One school accepts the hypothesis of Runnegar \& Pojeta (1974) that all bellerophontiform molluses are untorted (see also SalwiniPlawen, 1980, 1981). Another school insists that they are torted and hence gastropods (cf. Harper \& Rollins, 1982) while a third group supported herein argues that the bellerophontiform molluscs include representatives of both torted and untorted molluses (Berg-Madsen \& Peel, 1978; Linsley, 1977, 1978; Yochelson, 1978, 1979; Horny, in press $\mathrm{a}, \mathrm{b}$ ). Interpretation of muscle scars in bellerophontiform molluses has played a central part in this controversy.

While most of these groups assigned to the Monoplacophora by Runnegar \& Pojeta (1985) share a pre-
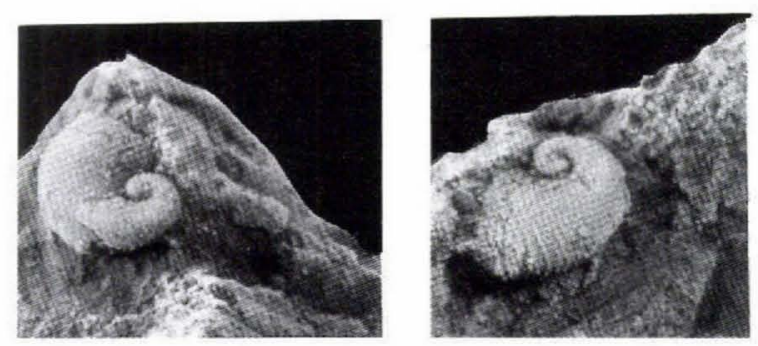

Fig. 7. Costipelagiella kochi Peel, 1988 from the late Middle Cambrian Holm Dal Formation, Peary Land, central North Greenland, MGUH 18.695 from GGU collection 225561, oblique apico-lateral views, $\times 20$. 

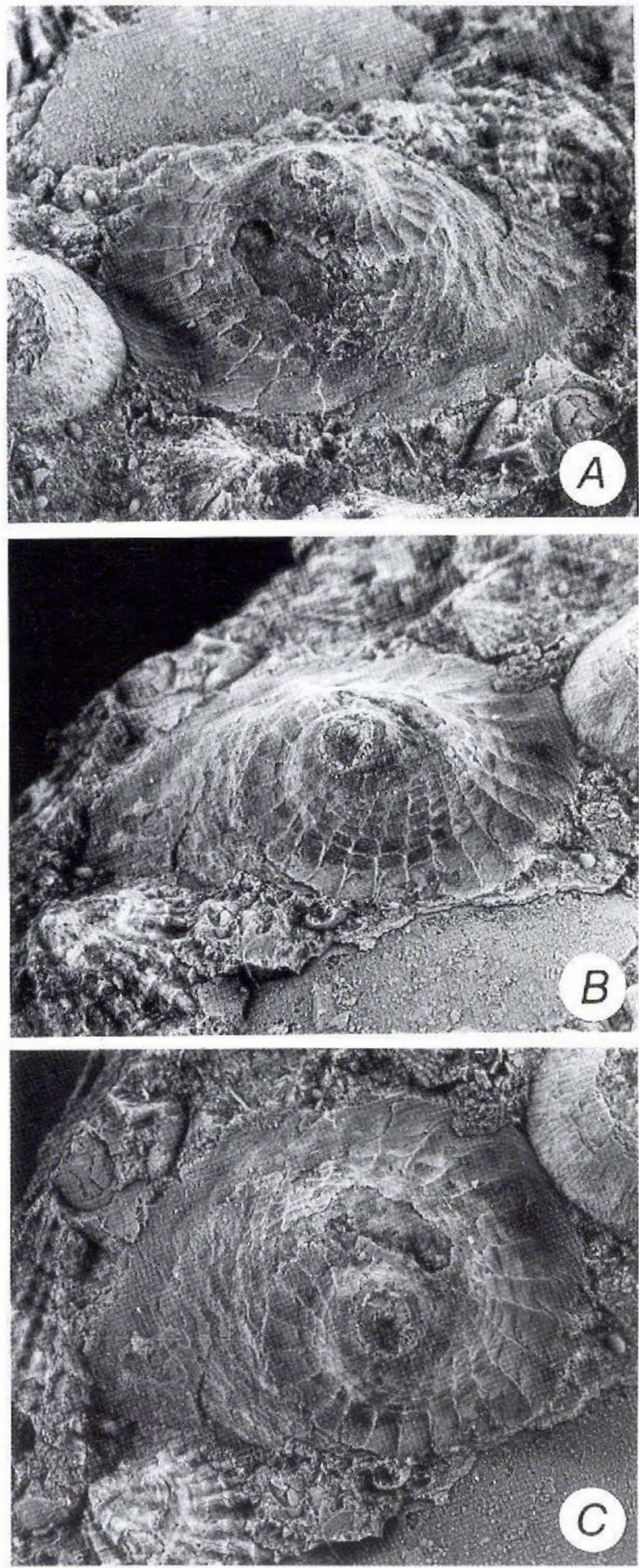

Fig. 8. Clisospira ellitsgaardi Peel, 1986 from the Early Silurian Cape Schuchert Formation, Kap Schuchert, Washington Land, western North Greenland, MGUH 16.778 from GGU collection 216482, holotype, $\times 6$. This member of the Class Paragastropoda is shown in oblique lateral views $(\mathrm{A}, \mathrm{B})$ and in apical view; note the sinistral coiling in contrast to the dextral coiling characteristic of most gastropods. sumed basic untorted anatomy (except for the torted bellerophontids and archinacellids) and univalved shell (except for the tuarangiids), they clearly represent a broad array of adaptations in the earliest Palaeozoic history of the Mollusca. Indeed, Linsley \& Kier (1984) considered pelagiellids (Fig. 7) to be part of their new Class Paragastropoda, together with the sinistrally coiled clisospirids (Fig. 8), macluritids and euomphalids, while MacKinnon (1982, 1985), Berg-Madsen (1987) and Krasilova (1987) thought that tuarangiids were bivalves.

Salwini-Plawen $(1980,1981)$ introduced the name Class Galeroconcha to include the Orders Tryblidiida (which he equated with Monoplacophora) and Bellerophontida (as Belleromorpha) which were considered to be untorted molluscs, although the Amphigastropoda Simroth, 1904 has a similar scope (see also Wenz, 1940 and Geyer, 1986). Galeroconcha is not used by SalwiniPlawen (1985; fig. 42).

Harper \& Rollins (1982) reviewed the characters used by earlier workers in attempting to delimit the untorted monoplacophorans from the torted gastropods. They restricted the Class Monoplacophora to the tryblidiacean lineage, the Sub-class Tergomya of Horny (1965a, b), considering Horny's cyclomyans to be gastropods. By direct statement or implication, they excluded from this restricted Monoplacophora ten families of supposedly untorted molluses which were placed in three orders within the Class Monoplacophora as defined by Runnegar \& Jell (1976) and Runnegar \& Pojeta (1985).

Geyer (1986) maintained a Class Monoplacophora but recognised that the helcionellids may represent a higher taxon separate from the tryblidiaceans.

\section{Monoplacophora: current usage}

It is apparent that the term Class Monoplacophora has not enjoyed stability since its inception. Thus, Peel (1991a) followed Wingstrand (1985) and others in recommending that Monoplacophora be abandoned as a class on account of this diverse and confusing usage. Peel could not accept the embracive usage of Class Monoplacophora employed by Runnegar \& Jell (1976), Runnegar in Bengtson et al. (1990) and others. The Class Monoplacophora might have been restricted so as to be equivalent to the Class Tergomya of current usage, but this would scarcely alleviate the confusion in meaning present among contemporary writers. Sympathy is expressed for the plea of Horny (in press a) “...urgently interceding for the preservation of [Monoplacophora]" and restating his concept of Tergomya and Cyclomya as monoplacophorans. While the latter restatement is partly accepted, the intercession is reluctantly rejected. 
Peel's (1991a) abandonment of the term Class Monoplacophora is restated and the Class Tergomya is further stabilised with the description of three constituent orders, below.

'Monoplacophoran' is an excellent term to cover the variety of untorted molluscs in a general sense, as an evolutionary grade, but this wide application is considered to be too great to accomodate within a single class. Haszprunar (1988) used the term at Super-class level, but to contain only a single Class Tryblidiida. Terms such as monoplacophoran, monoplacophore or monoplacophorous may prove to be useful descriptors for untorted molluscs with a single coiled or cap-shaped shell in general discussion.

Peel (1991a) developed ideas expressed in an earlier paper (Peel, 1988b) and recognised two major lineages of monoplacophorous molluses separated mainly on the basis of their direction of shell coiling. The Sub-class Tergomya of Horny $(1965 \mathrm{a}, \mathrm{b})$ was elevated to a full class to essentially replace Monoplacophora in the restricted sense of Harper \& Rollins (1982), i.e. the Pilina and Tryblidium morphological group. The alternative term Tryblidiida has been employed by Wingstrand (1985), Haszprunar (1988) and others at a similar systematic level to the use of Tergomya, but without defini- tion. Tryblidiida, however, has also been widely used as an order of the Class Monoplacophora and, as such, attributed to Lemche (1957) by many authors (e.g. Horny 1965a, b; Runnegar \& Jell, 1976; Runnegar \& Pojeta, 1985); this ordinal usage is preferred here. The concept of the Class Tergomya as expressed by Peel (1991a) is one of exogastrically coiled, untorted, univalved molluscs, usually with paired muscle insertions on the shell interior.

Peel (1991a) proposed a Class Helcionelloida to include the genera Latouchella Cobbold, 1921 (Figs 9, 10), Helcionella Grabau \& Shimer, 1909 (Fig. 11) and their relatives which he distinguished from the tergomyans mainly in terms of their endogastric coiling (see Fig. 12).

In the present paper, the concept of exogastric Tergomya and endogastric Helcionelloida is further developed. The scope of the Tergomya is expanded from the original Pilina and Tryblidium group to take account of strongly coiled cyclomyans not discussed in the original proposal; three orders of Tergomya are recognised, one of which is new.

The idea of a major division within the untorted, bilaterally symmetrical, univalved molluscs (i.e. Monoplacophora in the sense now abandoned) based on dif-
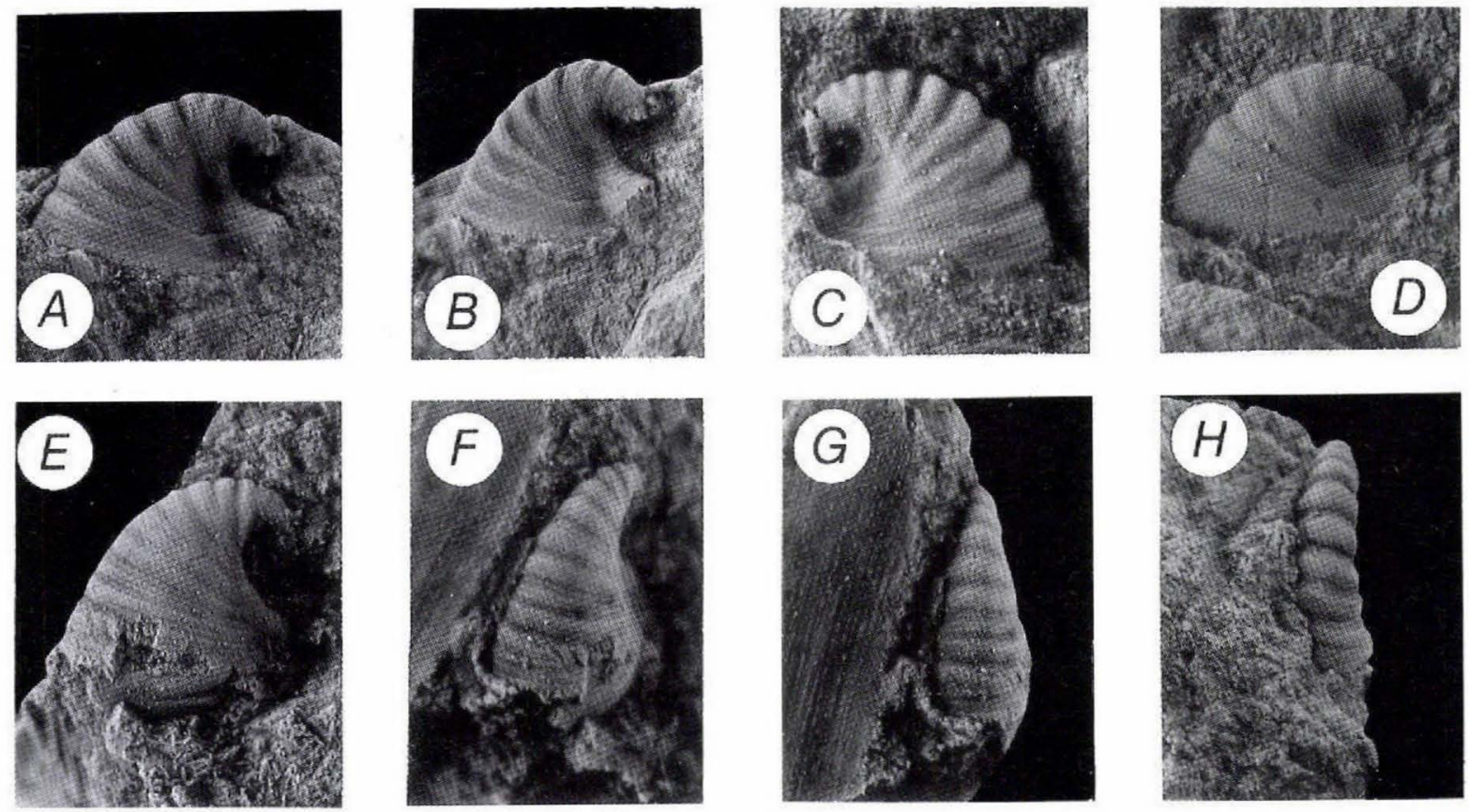

Fig. 9. Latouchella holmdalense Peel, 1988 from the late Middle Cambrian Holm Dal Formation, Gustav Holm Dal, Peary Land, central North Greenland, GGU collection 225535, × 10. A, B, H, MGUH 18.678, the holotype in lateral, postero-lateral and anterior views, showing the prominent apertural fold on the posterior, sub-apical surface. C, MGUH 18.679 in lateral view with the anterior to the right. D, MGUH 18.680 in lateral view with the anterior to the left. E-G, MGUH 18.681 in lateral, antero-lateral and anterior views. 

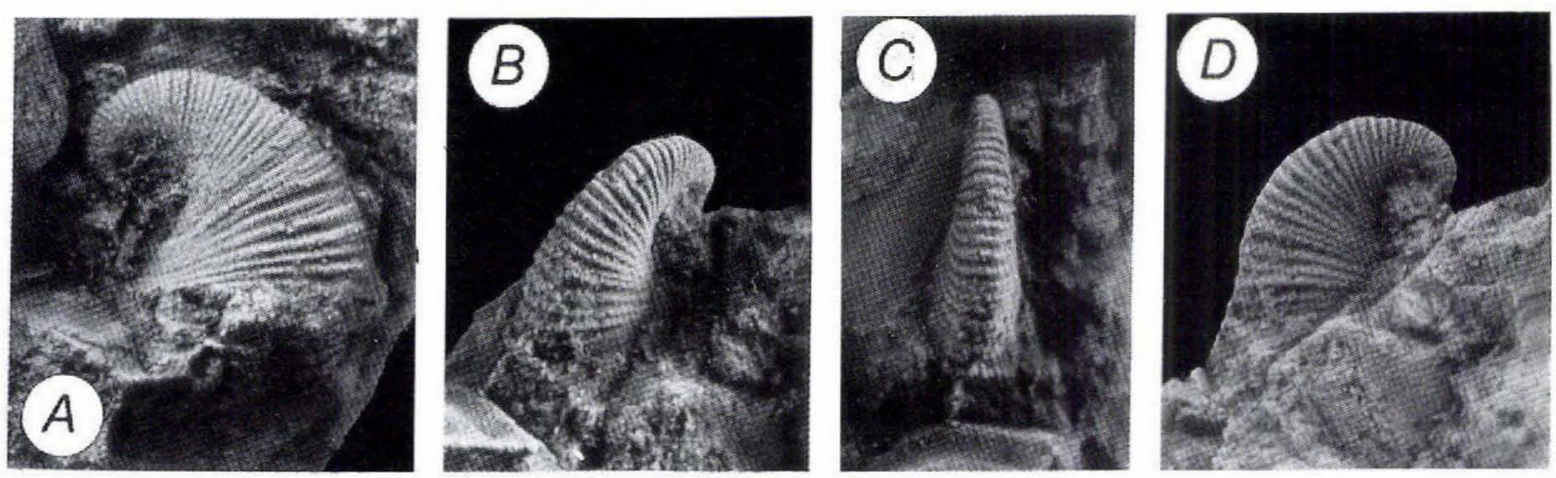

Fig. 10. Latouchella pearylandica Peel, 1988 from the late Middle Cambrian Holm Dal Formation, Gustav Holm Dal, Peary Land, central North Greenland, GGU collection 225561. A, MGUH 18.683 in lateral view with a shallow lateral emargination indicated by the concavity of the comarginal plications, $\times 10$. B-D, MGUH 18.684 , the holotype in antero-lateral, anterior and lateral views, $\times 13$.

ferences in shell coiling is not new, although insufficient information has been published previously to give it credence or the ideas have not been fully developed. Yochelson (1978; 1979), Geyer (1986) and Peel \& Yo- chelson (1987) reconstructed helcionellids with endogastrically coiled shells, anticipating the formalisation proposed by Peel (1991a) and here.

Doguzhaeva (1981, p. 210) foresaw a dichotomy in a
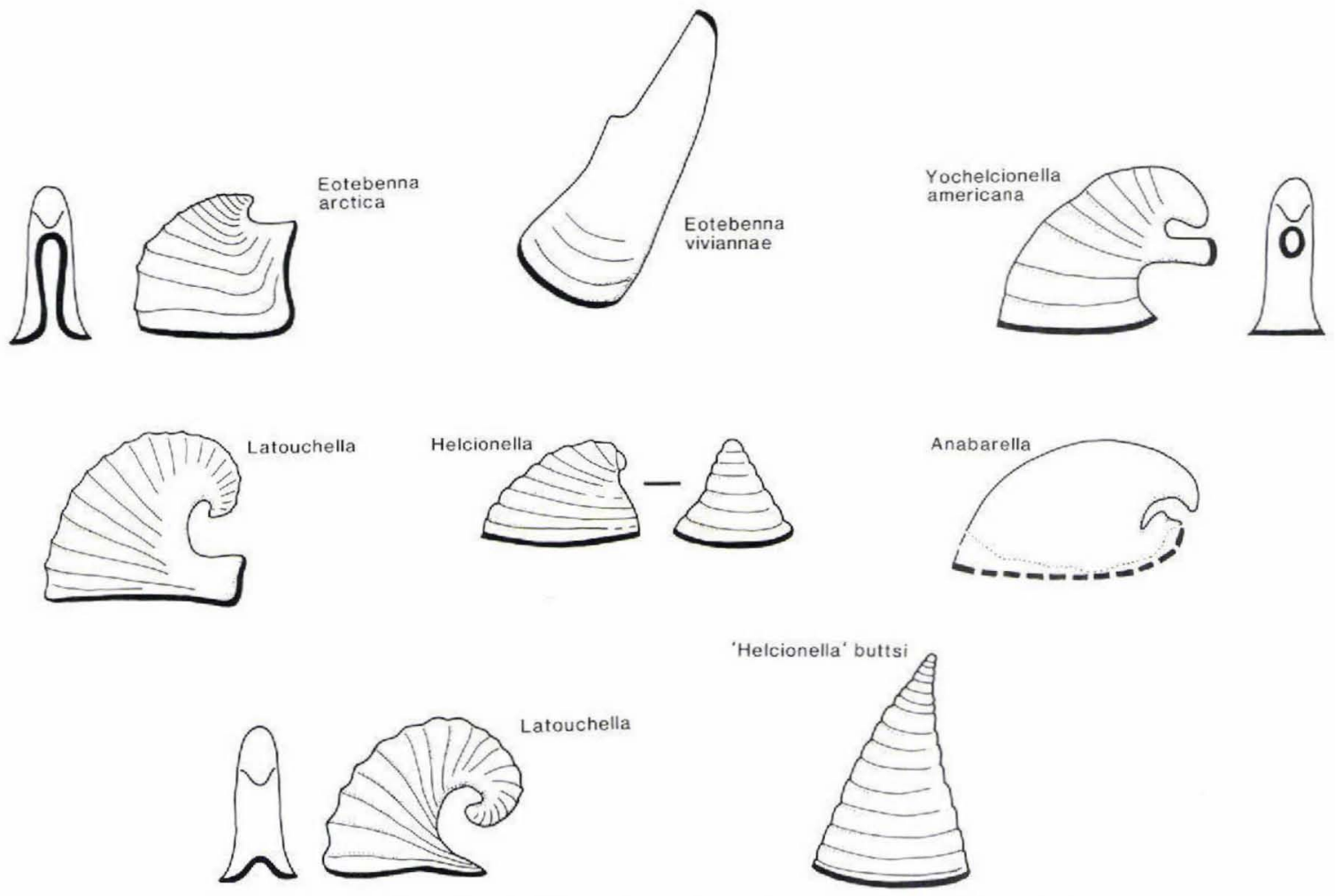

Fig. 11. Morphological variation within the Class Helcionelloida. All specimens are drawn in lateral view with the anterior to the left. Helcionella is shown in anterior and lateral views. Schematic drawings show the extent of the emargination in the posterior, sub-apical apertural margin in Latouchella, Eotebenna arctica and in Yochelcionella. The drawing of Anabarella is based on Runnegar (1983, fig. 4A); the preserved margin is shown by the stippled line and the inferred aperture by the heavy broken line. Apertural margins are indicated by thick black lines. 
Fig. 12. Reconstructions of the helcionelloid Latouchella. A, Runnegar \& Pojeta (1974), with inhalant water currents entering the shell anteriorly prior to postero-lateral exhalation. $B$, reconstruction favoured here. Inhalant currents enter the endogastric shell laterally while the exhalant stream leaves the mantle cavity along the median posterior margin. This reconstruction forms the basis of the Class Helcionelloida.
A

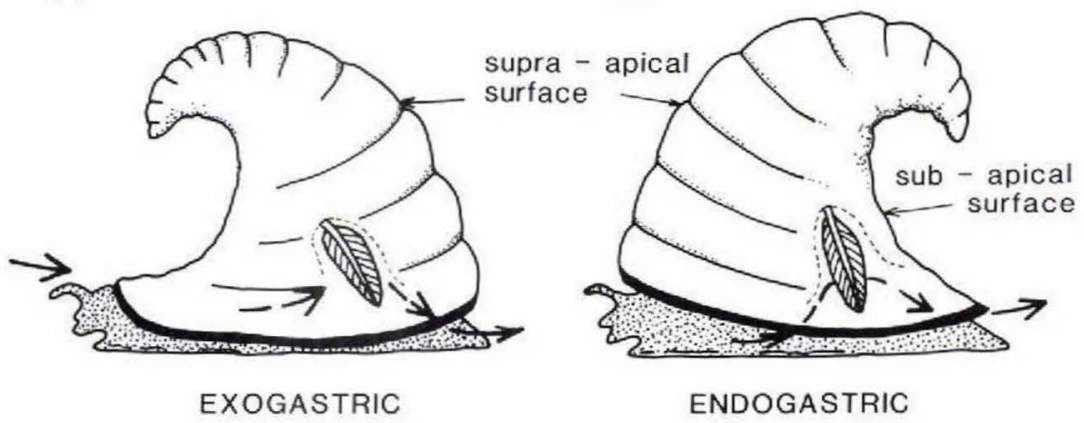

different context in proposing an Order Romaniellida for supposedly endogastric monoplacophorans (see Fig. 17 , below). Her interpretation of an anal sinus in the sub-apical wall of Early Ordovician Romaniella Doguzhaeva, 1972 from the Soviet Union caused her to reinterpret this genus as endogastric and not exogastric, and to speculate that "...future studies of Monoplacophora will probably lead to the separation of ... three branches of development - three sub-classes within the Class Monoplacophora" [translated from Russian].

Doguzhaeva (1981) commented that Latouchella has much in common with Romaniella in terms of shell form and should not be treated as a gastropod as suggested by Knight et al. (1960), although contemporary authors already considered it to be untorted (cf. Runnegar \& Jell, 1976). Uncertainty surrounding the status of Romaniella extends to many other cap-shaped and isostrophically coiled shells of similar age. It appears to be an unusual tergomyan; its reported broad emargination is not an unequivocal indicator of posterior since laterally compressed forms tend toward the development of lateral shields of the shell. Indeed, Stasek (1972, fig. $11 \mathrm{~A}$ ) inferred a hypothetical 'monoplacophoroid' ancestor to the Class Bivalvia with similar lateral shields and resultant, broad, anterior and posterior emarginations.

Doguzhaeva (1981) considered Romaniella to be some form of predecessor to the Order Archinacellida but archinacellids are here considered to be gastropods (see discussion below).

Yochelson et al. (1973, p. 286), while discussing the origin of cephalopods from tall monoplacophorans, correctly concluded that "one can not determine the anterior or posterior of a curved...or indeed any cap-shaped shell simply by observing the shell curvature." Peel (1988b) extended the discussion by noting that the position of the apex relative to the anterior and posterior margins in such shells also may be quite unconnected with the direction of coiling, as partly illustrated by Rozov (1969, fig. 5) in considering exogastrically coiled shells (see also discussion below).

The need for functional morphological analyses of shell form in monoplacophorans of the type developed within the Class Bivalvia (e.g., Stanley, 1975; Allen, 1985; Vermeij \& Dudley, 1985) and the Class Gastropoda (e.g. Linsley, 1977, 1978; Peel, 1974, 1984; Vermeij, 1975) to constrain interpretations of direction of coiling is evident. A number of relevant studies exist, e.g., Horny (1970) and Peel (1977a) discussed inhalant emarginations in fossil Tergomya while Rollins \& Batten (1968), Peel (1980a), Linsley \& Peel (1983) and Peel \& Yochelson (1987) discussed more strongly coiled species. Linsley \& Kier (1984) based their proposal of the molluscan Class Paragastropoda on functional morphological analysis while Peel (1991a) used this approach as the basis for formalising the separation of the two classes Tergomya and Helcionelloida.

\section{The question of size}

Absolute size is one biological parameter which is often neglected in functional morphological interpretations of molluscs. Within the Gastropoda, shells with similar morphologies occur in widely separated environments where absolute size may be a limiting parameter. Thus, gastropod faunas which are supported by algal or other foliage at the present day rarely exceed 2 $\mathrm{mm}$ in length (Warmke \& Almodovar, 1963; Brasier, 1975), a size limitation which encouraged Peel (1977b, $1978,1984)$ to recognise possible foliage-supported gastropod faunas in the Silurian.

Runnegar \& Jell (1976; see also Runnegar \& Pojeta, 1985 ) noted the small size of early Cambrian molluscs, noting a subsequent increase in size as a conspicuous trend in molluscan evolution. To some extent this common size range of $1-2 \mathrm{~mm}$ in the Early Cambrian may 
be a function of preservation or sampling bias since phosphatisation within coiled and cap-shaped forms is commonly restricted to near the apex. Thus, examination of phosphatic acid residues (a common form of study) may present an imperfect indication of true size ranges. Dzik (1991) demonstrated that centimetre-sized helcionelloids do occur in the earliest Cambrian of the U.S.S.R. even though most of their systematics is based on phosphatised internal moulds up to ten times smaller (cf. Missarzhevsky, 1989; Yu, 1987). Nevertheless, in a general sense, the observation of Runnegar \& Jell (1976) appears to be correct and many of the Early and Middle Cambrian molluscs discussed here fall within this 1-2 mm size range (cf. Figs 23, 24, 27, 29, 31).

Specimens of this small size experience different physical and biomechanical constraints than molluscs ten times larger (and perhaps one hundred times more voluminous) and can only be interpreted functionally with great uncertainty when the larger morphologies serve as the functional reference point. The relationship to surface tension is critical, for example, in interstitial faunas (Swedmark, 1968).

In the present context mantle cavity reconstructions are discussed for a number of small helcionelloids, often invoking models based on larger bellerophontacean gastropods. The validity of some of these reconstructions remains to be tested from the point of view of fluid mechanics. For example, it may prove unlikely that water could have been transported through the narrow snorkel of Yochelcionella (cf. Figs 28, 32, below), although the often minute distal opening of many small present-day scaphopods suggests that it was possible. Clearly, if the conduit in Yochelcionella was too narrow for water transport, the entire basis for the reconstruction is lost and the snorkel must be interpreted using another functional model.

The precept is followed that the mantle cavity reconstructions discussed below are possible in organisms of this small size. This approach is therefore the same as that employed by Runnegar \& Pojeta $(1974,1985)$ and Pojeta \& Runnegar (1976), although the conclusions offered below concerning the reconstruction of the helcionelloids are diametrically opposed. In the case of Yochelcionella, the former authors interpreted the function of the snorkel as inhalant while herein it is considered exhalant. Both interpretations assume that water transport was possible.

\section{Class Tergomya}

The best known tergomyan lineage, the Tryblidiida, can be traced back from the present day Neopilina, through familiar fossil forms such as Pilina (Fig. 1) to the morphologically very similar Late Cambrian and Early Ordovician genus Proplina Kobayashi, 1933. Univalves from older Cambrian strata (e.g. Kalbyella BergMadsen \& Peel, 1978 from the Middle Cambrian of Denmark and Australia) may extend the antiquity of this record.

Tryblidiidans are often considered to be the close descendants of the ancestral group of other conchiferous molluscs but possible members of the Tryblidiida are conspicuously less common in the Early and Middle Cambrian than members of the Class Helcionelloida.

\section{Cyclomya - gastropods or monoplacophores?}

In association with the description of the Helcionelloida and Tergomya, Peel (1991a) recounted that Harper \& Rollins (1982) had assigned the second of Horny's (1965a, b) sub-classes of the now abandoned Monoplacophora, the Sub-class Cyclomya, to the Class Gas- tropoda. However, the status of most cyclomyan genera was not discussed by Peel in order to stress the fundamental difference in coiling between the endogastric Helcionelloida and the exogastric Tergomya. Exceptions were provided by the small group of genera centred around Archinacella Ulrich \& Scofield, 1897, which were assigned to the Gastropoda in agreement with Starobogatov (1970), Harper \& Rollins (1982), Yochelson (1988) and Peel (1990a), and by the Superfamily Hypseloconellacea of Stinchcomb (1986) which Peel considered to comprise atypically coiled tergomyans.

The decision to place the Hypseloconellacea within the Tergomya, and not within the Cyclomya as suggested by Harper \& Rollins (1982), was based on ontogenetic studies of Knightoconus by Webers \& Yochelson (1989) and Webers et al. (in press). Knightoconus and Hypseloconus were interpreted by Peel (1991a) as pseudo-endogastrically coiled tergomyans in which the unusually high shell (for a tergomyan) encompassed a change of coiling from the initial exogastric form to an ontogenetically later endogastric form (see discussion below). 
Acceptance of Hypseloconus as a tergomyan may offer a clue to the affinities of other supposed cyclomyans, in particular members of the Order Cyrtonellida Horny, 1963a in which the muscle scars have been excellently described by Horny (1963a; 1965a, b; see also Horny, 1990; in press a, b).

According to Horny (1965a, b), the fundamental difference between tergomyans and cyclomyans is the relationship between the circle of muscle scars and the apex of the shell. In tergomyans the apex lies outside of the dorsally placed muscle field while the apex lies within
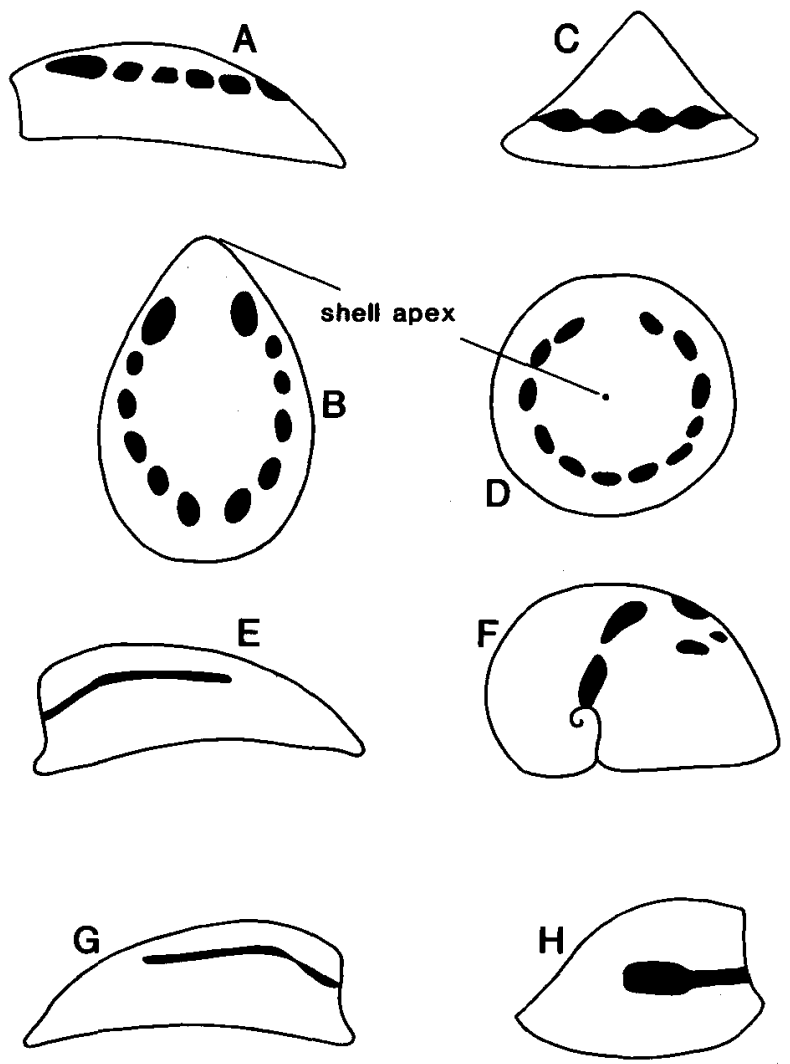

Fig. 13. Muscle scar patterns of 'tergomyan and cyclomyantype' (cf. Horny, 1965a, b). A, B, internal mould of an untorted tryblidiid tergomyan shell exemplified by Pilina in lateral and dorsal views in which the circle of muscle scars lies on the dorsal surface and does not contain the shell apex ('tergomyan-type'). C, D, a cap-shaped shell in which the circle of muscle scars is arranged concentrically around the shell apex ('cyclomyan-type'). E, Archinacella interpreted as an untorted mollusc with the anterior to the left and the muscle scar of 'cyclomyan-type' passing below the shell apex. F, a cyrtonellid with muscle scars of 'cyclomyan-type', anterior to left. G, Archinacella interpreted as a gastropod with the apex at the posterior and the anterior to the left. $\mathrm{H}$, the patelliform gastropod Metoptoma oriented with the anterior to the left, for comparison with Archinacella.

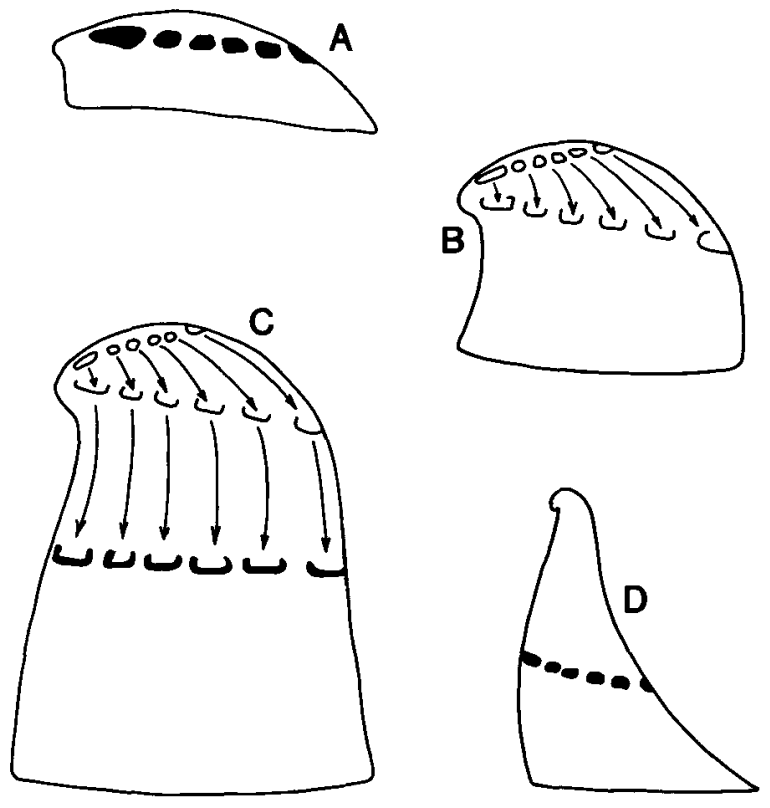

Fig. 14. Hypothetical derivation of a hypseloconid tergomyan such as Knightoconus (D) from a tryblidiid tergomyan such as Pilina (A). Increase in the tightness of coiling and height of the shell leads to migration of muscle scars from the 'tergomyantype' (A) to 'cyclomyan-type' (B-D). The change is emphasised by the change in coiling pattern from exogastric in the early growth stages to pseudo-endogastric in the adult (D).

the muscle scar circlet in cyclomyans (Fig. 13A-D). The difference is striking when the tergomyan Pilina is compared with the supposed cyclomyan Archinacella of similar shell form (cf. Fig. 13A, E). Archinacella, however, is now considered to be a gastropod and not an untorted mollusc, with the result that the apex is not located anteriorly (Fig. 13E), as in Pilina (Fig. 13A), but posteriorly (Fig. 13G). The muscle scars of Archinacella thus resemble the sub-apical posterior muscle scars of limpet gastropods such as Metoptoma Phillips, 1836 or Lepetopsis Whitfield, 1882 (cf. Knight et al., 1960, fig. 143; see Fig. 13H).

Most cyclomyans are morphologically distinct from the low, elongate shells of Pilina; the tall shells of hypseloconellaceans and the strongly coiled shells of cyrtonellids (Fig. 13F) naturally require different patterns of muscle attachment than that present in Pilina. As shell growth parameters change, so will the disposition of muscle attachment sites, in response to changed biomechanical requirements. Muscle scars in Knightoconus can scarcely avoid changing from a tergomyan pattern in the juvenile to a cyclomyan pattern in the adult, as the tall pseudo-endogastric shell develops (Fig. 14A-D). Likewise, strong coiling through several whorls and a low rate of whorl expansion in some cyrtonellids will 
almost inevitably result in the acquistion of muscle scars of cyclomyan type (Fig. 15), although more rapidly expanding forms with fewer whorls such as Cyrtonella Hall, 1879 may well retain muscle scars which are more prominent on the dorsal surface (Rollins, 1969; Wingstrand, 1985, fig. 19).

Increase in coiling can clearly explain derivation of hypseloconellacean and cyrtonellid muscle scar patterns from a tryblidiid shell (Figs 14, 15). However, the elongate tryblidiid form with its dorsal circlet of muscle scars may itself represent a strongly modified morphology rather than an ancestral form. Pronounced anterior displacement of the apex to produce a low, elongate shell of Pilina type, resulting from a rapidly expanding logarithmic spiral, may encourage migration of muscle scars from an originally circum-apical (cyclomyan) distribution to supra-apical (tergomyan) pattern (Fig. 16). Unfortunately, centralisation of an originally anterior apex could equally well lead to the assumption of a cyclomyan muscle field from an original tergomyan pattern.

\section{The ancestral condition}

Arguments concerning which morphology came first, the chicken or the egg, the cyclomyan or the tergomyan condition, must invoke other criteria than simple shape. A significant aspect in these discussions is geological age since some of the oldest cyclomyans (e.g. the hypseloco-
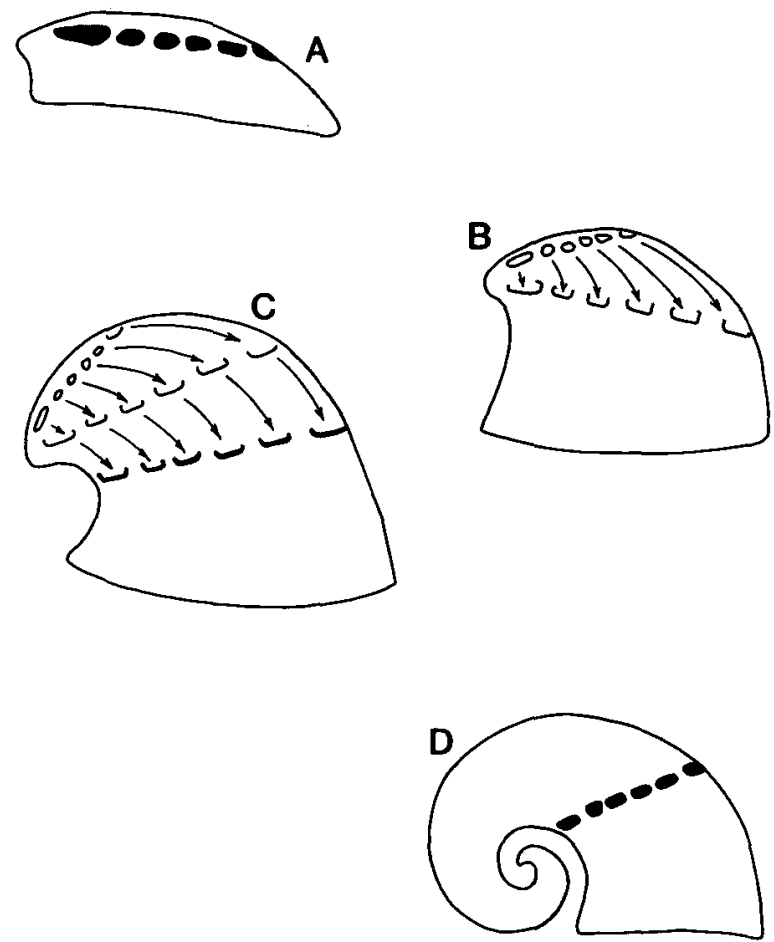

Fig. 15. Hypothetical derivation of a cyrtonellid tergomyan (D) from a tryblidiid tergomyan (A). Tightening of the shell spiral and increased shell growth lead to derivation of muscle scars of 'cyclomyan-type' (D) from the original 'tergomyan-type' (A).
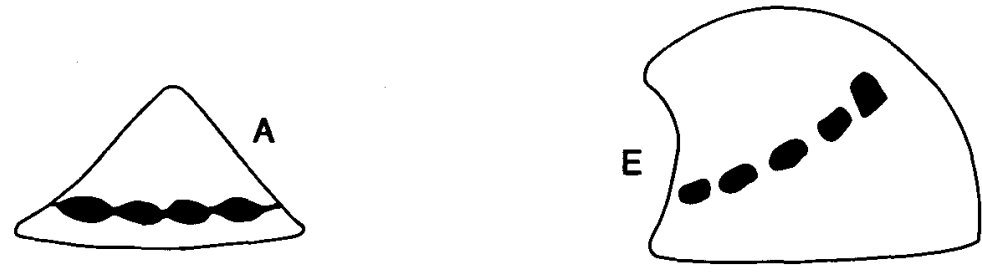

1
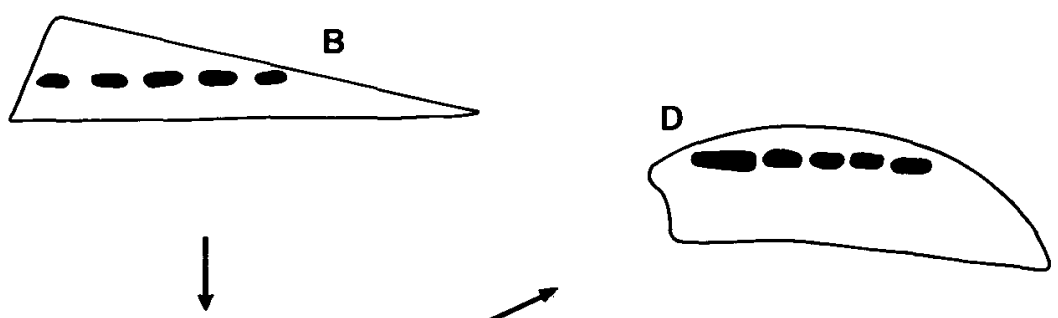

Fig. 16. Hypothetical derivation of a low, elongate, tryblidiid tergomyan (D) from a cap-shaped shell with muscle scars of 'cyclomyan-type' (A). Displacement of the apex to the anterior (A-C) and increase in coiling (D) tend to displace the circle of muscle scars addorsally. $E$, hypothetical member of the Order Kirengellida Rozov, 1975 in which muscle scars of 'cyclomyan-type' are associated with a tall, slightly coiled shell form. 
Fig. 17. Radiation of untorted molluscs ('monoplacophorans') from the ancestral kirengellid form according to Rozov (1975) and Doguzhaeva (1981).

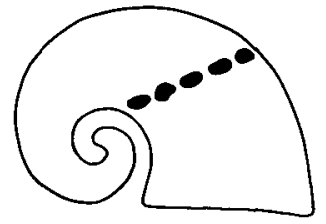

Cyrtonellida

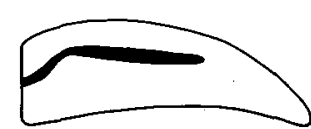

Archinacellida

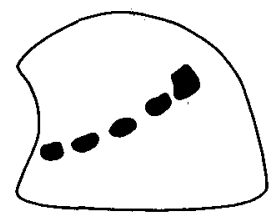

Kirengellida

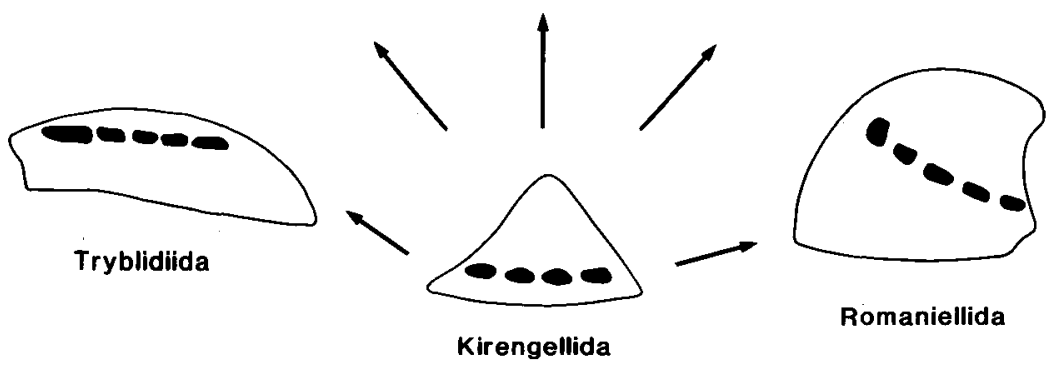

nids from the late Middle Cambrian Holm Dal Formation of North Greenland described by Peel, 1988b) appear prior to the common appearence of univalves such as Proplina with muscle scars in a tergomyan pattern. However, the imperfections of the fossil record are notorious, as adequately documented by the absence of recognised tryblidiid tergomyans between the Devonian and the Cenozoic.

Rozov (1975) proposed that the 'primitive' monoplacophoran form was a cap-shaped or slightly coiled shell with muscle scars arranged concentrically around the apex (cf. Fig. 16A, E). He placed these shells in his new Order Kirengellida and derived other 'monoplacophoran' orders from this stock. Thus, he considered tryblidiids and archinacellids to be derived by anterior displacement of the apex and flattening of the shell, while cyrtonellids increased the degree of coiling. All orders were assumed to be exogastric (and consideration of helcinelloids was not given) but Doguzhaeva (1981) extended the concept by proposing that her new Order Romaniellida represented an endogastric branch from the original kirengellid stock (Fig. 17).

The model of Horny (1965a) implies derivation of the cyclomyan form with a central apex from an elongate ancestor to the Tergomya. The model also accords well with hypotheses recently stated by Salvini-Plawen (1985; see also Runnegar \& Pojeta, 1985 and Wingstrand, 1985; see also Peel, 1991b) concerning the derivation of molluscs from a spiculate worm similar to living Aplacophora.

In a grossly simplistic sense, the morphological sequence from spiculate aplacophoran to multivalved polyplacophoran (by coalescence of spicules into a sequence of plates) may be argued to find its logical continuation in the fusion of individual elements within the series of polyplacophoran valves to form the univalved, elongate tergomyan shell, with the serial muscle scars, gills and other organs representing the primitive condition. As noted by Wingstrand (1985, p. 61), however, such a direct sequence is neither necessary nor desirable; polyplacophorans and tergomyans were probably derived from a similar spiculate stock by separate events of spicule fusion. The halkieriid described by Conway Morris \& Peel (1990; see also Peel, 1990b) and discussed in this volume (Peel, 1991b) possibly represents a third independent event even though its overall morphology suggests a tantalizing intermediate stage between the spiculate progenitor and eight-valved polyplacophorans Rolfe (1981) has demonstrated that the supposed seven-valved polyplacophoran Septemchiton Bergenhayn, 1955 in fact has eight valves, although seven-valved forms still persist in the model of SalwiniPlawen, 1985). Again, the known geological distribution of both undoubted polyplacophorans and tryblidiidan tergomyans shows a complicating late appearence of both groups near the Cambrian-Ordovician boundary. The simple model also neglects the effect of changing shell shape on differentiation of muscle scars.

\section{Sub-class Cyclomya abandoned}

The morphological scenario painted above casts doubt on the usefulness of the term Cyclomya in a phylogenetic classification, as a group of equivalent status to the Sub-class Tergomya, since it can be expected that 'cyclomyan' shells developed independently at different times and from different stocks within the Tergomya, in response to changes in coiling parameters. In 
particular, the Hypseloconellacea may have little in common with the members of the Order Cyrtonellida.

The terms Tergomya and Cyclomya have not gained wide acceptance as sub-classes of the Class Monoplacophora since their proposal by Horny $(1965 \mathrm{a}, \mathrm{b})$ and were not employed by Starobogatov (1970), Runnegar \& Jell (1976) or Runnegar \& Pojeta (1985, but see Stasek, 1972; Morton, 1979). While Tergomya is now established at class level, Cyclomya is not employed. Consequently, the two orders which Horny (1965b) referred to the Cyclomya are relocated. The Order Cyrtonellida Horny, 1963a is transferred to the Class Tergomya and the Order Archinacellida Knight \& Yochelson, 1958 sensu Horny, 1965b is transferred to the Gastropoda.

\section{Gastropods or retractile tergomyans}

Most exogastrically coiled untorted molluscs can be readily placed within the cyrtonellid Tergomya. However, the sinuitids (Sinuites Koken, 1896, Strangulites Horny, 1962 and Sylvestrosphaera Peel, 1980a) preserve muscle scar patterns which are difficult to reconcile with this assignment yet are not immediately reconcilable with the torted gastropod Bellerophon. The muscle attachment areas are not distributed around the whorl, as in Cyrtonella or Sinuitopsis (Fig. 18D-F), but consist of a single curved scar, or a pair of scars joined by a thin strand, near each umbilical shoulder, more than half a whorl back from the shell mouth (Fig. 18A-C). In position they resemble the scars of Bellerophon, although
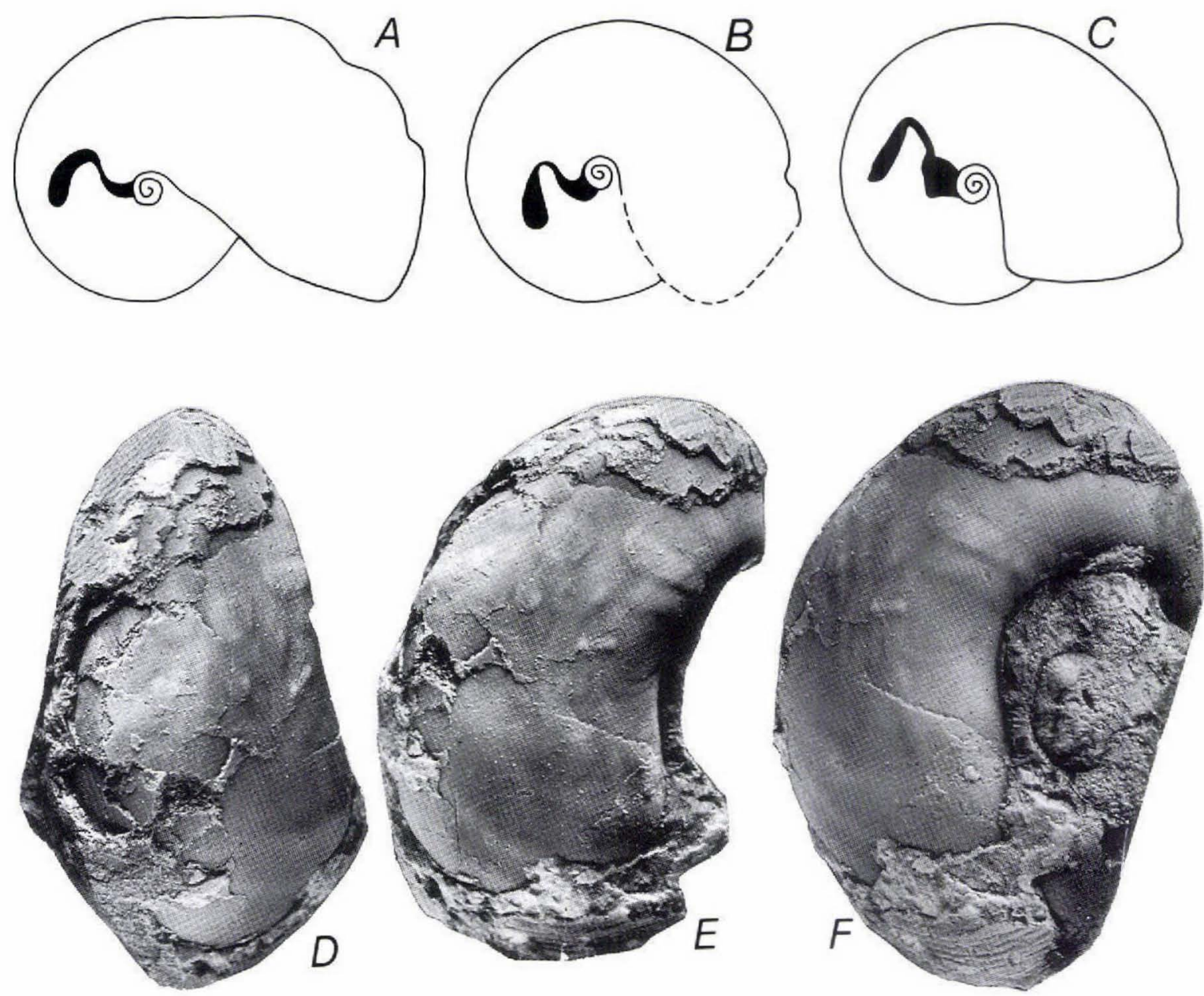

Fig. 18. Muscle scars in Sinuites (A), Strangulites (B) and Sylvestrosphaera (C), all shown in lateral view with the presumed anterior to the right (after Horny, 1990 and Peel, 1980a). D-F, Sinuitopsis neglecta Perner, 1903, partly exfoliated internal mould from the Lower Ordovician Zahotany Formation, Czechoslovakia, specimen P2 L 28633, $\times 3.5$. Note the deeply impressed multiple muscle scars represented by elevations on the internal mould; the lateral scar in F is repeated (photographs by Radvan J. Horny). 
each of the single pair of muscle scars in the latter genus is V-shaped (cf. Peel, 1982). A suggestion by Peel (in Runnegar \& Jell, 1980; Peel, 1980a, 1987; see discussion by Horny, 1990) that three pairs of muscle scars may have been present in Sinuites has not been substantiated by later work (Horny, 1990; in press a, b; personnal communication, 1990; J. S. Peel, unpublished observations).

Knight (1947) described muscle scars in Bellerophon and Sinuites. He gave no indication that he considered the muscle scars in the two genera in any way to be different although both were considered to be gastropods and readily separable from the untorted Cyrtonella with its paired dorsal muscle scars. In 1976 Peel argued strongly for the similarity between muscle scars in these two genera, based on Knight's descriptions (see also Berg-Madsen \& Peel, 1978) and an undescribed illustration of Sinuites ammonoides Koken, 1897 from the Baltic Ordovician (Koken \& Perner, 1925, pl. 18, fig. 16). However, Peel (in Runnegar \& Jell, 1980; Peel, 1980a, 1987) recanted his belief that Sinuites was a gastropod, considering the muscle scar pattern to indicate an untorted mollusc, a monoplacophoran of the then current usage. The muscle scars in Sinuites were considered to more closely resemble the muscle scars of Cyrtonella and other cyrtonellid tergomyans (cf. Horny, 1963, 1965a, b) than the muscle scars of Bellerophon (cf. Peel, 1982), although this opinion was undoubtedly influenced by the now abandoned interpretation of three pairs of muscle scars in Sinuites.

Peel (1980a) described two pairs of muscle scars joined by a thin strand on the umbilical shoulders of a new Silurian genus, Sylvestrosphaera (Figs 18C, 19), noting its similarity to Sinuites (the dorsal area in the only known specimen was too poorly preserved to contribute decisively to the discussion concerning the third pair of muscles at that time believed to be present in Sinuites). Horny (1990) described similar muscle scars in Strangulites (Fig. 18B), placing all three genera within the Family Sinuitidae Dall in Zittel-Eastmann, 1913, confirming the earlier suggestion of Peel (1980a).

The deep placement of the muscle scars within Sylvestrosphaera lead Peel (1980a) to infer the ability to retract into the shell, by comparison with Bellerophon (cf. Linsley, 1978 and Peel, 1987, a much delayed publication). Horny (1990) extended this interpretation to Sinuites and Strangulites, noting that cyrtonellids such as Cyrtonella and Cyrtolites probably clamped against the sediment surface instead of withdrawing into the shell.

Horny (1990) refrained from assigning the sinuitids to a molluscan class, although Peel (1980a) had argued that Sylvestrosphaera and Sinuites were retractile monoplacophorans (= Tergomya) and not bellerophontiform gastropods such as Bellerophon. This statement should be viewed in the light that Runnegar \& Jell (1976) and Runnegar \& Pojeta (1985) considered all bellerophontiform molluscs (i.e., cyrtonellids, sinuitids and true bellerophontaceans) to be untorted monoplacophorans while Harper \& Rollins (1982) considered them all to be torted gastropods. As stated previously (cf. Peel, 1976), the bellerophontiform molluscs are considered to be a mixture of untorted (cyrtonellid Tergomya) and torted forms (bellerophontacean Gastropoda) but the status of the sinuitids is less clear.

The muscle scars in sinuitids resemble the cyrtonellid Tergomya in terms of the shape of the scars and the presence of more than a single pair of muscle scars in Sylvestrosphaera. They resemble the muscle scars of bellerophontacean Gastropoda in comprising only a single pair of muscle scars in Sinuites and Strangulites (but not Sylvestrosphaera) and in their deep placement, although Horny (in press a) describes deeply placed scars from the cyrtonellid tergomyan Sinuitopsis. However, differences in the shape of muscle scars in sinuitids when compared with the single pair of muscle scars in Bellerophon may be illusory, since described specimens of the latter genus with muscle scars are of Carboniferous age and therefore significantly younger than the Ordovician and Silurian sinuitids. It is thus readily argued that the Bellerophon condition represents a further simplification of the sinuitid muscle scar pattern and that the two groups are closely related. This argument is strengthened by the description by Horny (in press b) of muscle scars in Sinuites from the Lower Ordovician of Bohemia which show continuous migration tracks comparable to those seen in Bellerophon. As noted by Horny (in press a), muscle scars in the tergomyan Sinuitopsis (Fig. 18D-F) relocate by saltation (see also Multifariites Bjalyi, 1973).

Muscle scars which appear comparable to the Bellerophon condition have also been described in Salpingostoma Roemer, 1876 and Megalomphala Ulrich \& Scofield, 1897 of similar age range to the sinuitids (Peel, 1972, 1976; 1991c; see Fig. 19). However, the whorl cross-section in these genera is morphologically quite distinct from the relatively globose, convex whorl profile of sinuitids and Bellerophon, and differences in muscle scar patterns may reflect variation in shell morphology.

It is imperative to bear in mind the warnings by Peel (1980a), Harper \& Rollins (1982) and others about the dangers inherent in attaching undue significance to differences in muscle scar patterns between morphologically disparate coiling forms.

Linsley (1978) and Peel (1980a, 1987; see also Morton, 1979) pointed to the torsion potential of retractile 


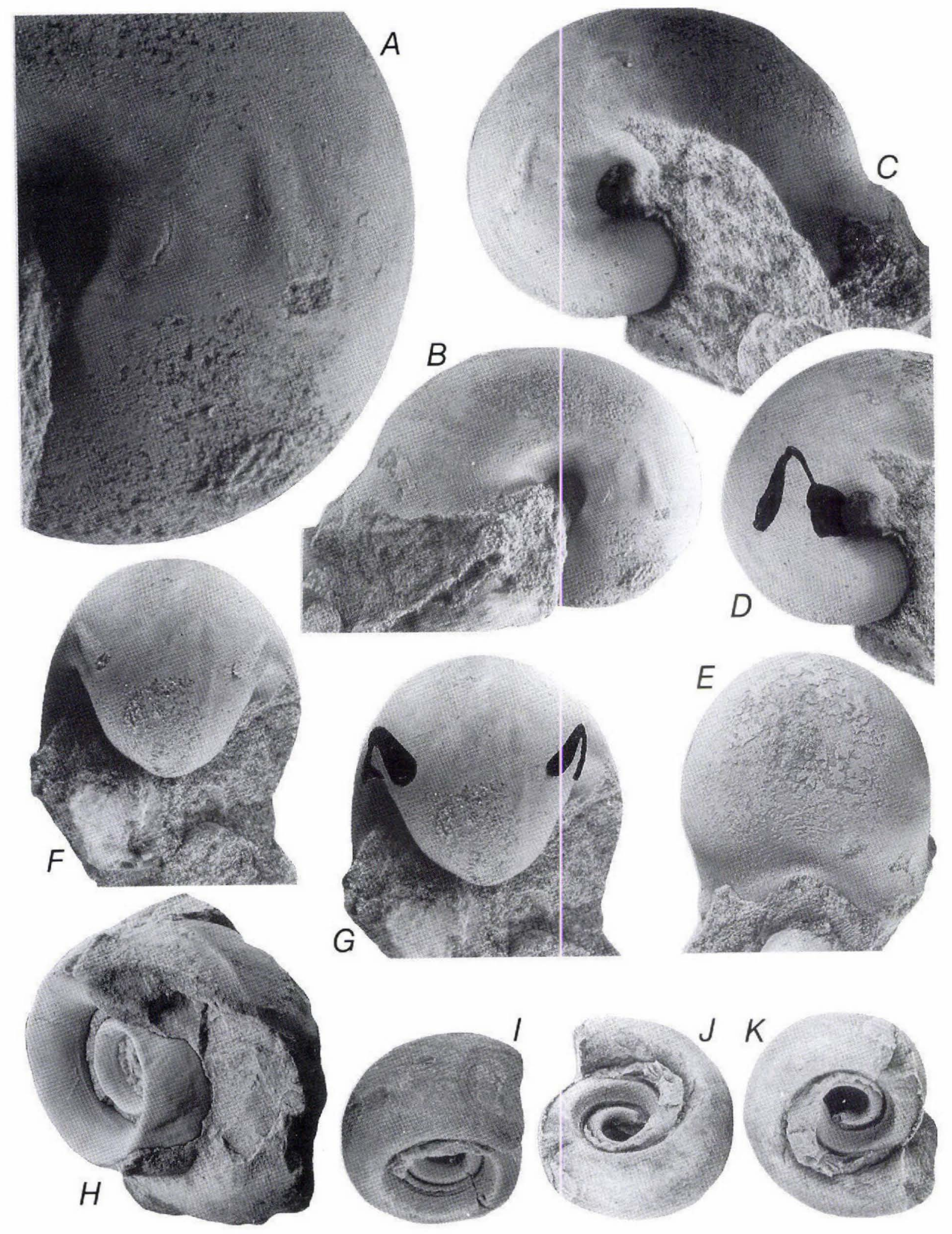


TERGOMYA

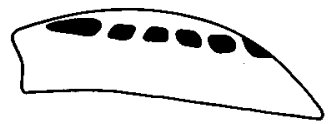

Tryblidiida

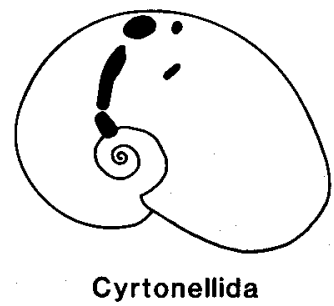

I
1
$T$
$O$
$R$
$S$
I
O
$N$
I
I
I

GASTROPODA

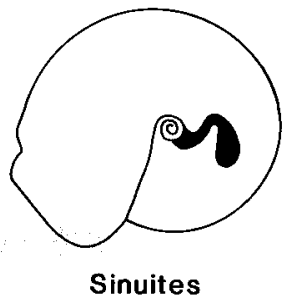

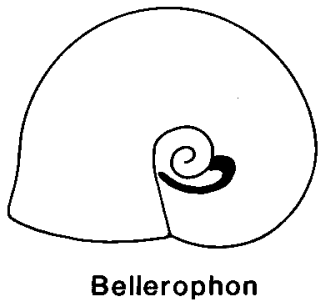

Fig. 20. Morphological sequence from Tergomya to bellerophontacean gastropod showing the possible origin of torsion. Musculature of 'tergomyan-type' in the Tryblidiida becomes 'cyclomyan' due to increased coiling in the Cyrtonellida. Concentration of muscle attachment areas moving by gradual anterior displacement (rather than the saltation characteristic of cyrtonellids) in the umbilico-lateral area of Sinuites and Bellerophon characterises the post-torsional molluscs.

monoplacophorans (= Tergomya) and its relevance to discussions of the origin of the Gastropoda. Their independent conclusion that it was unlikely that torsion occurred in a cap-shaped shell of the type characteristic of tryblidiid tergomyans stands in contrast to the opinion of Haszprunar (1988).

Interpretation of Sinuites and Sylvestrosphaera as intermediates between cyrtonellid tergomyans such as $\mathrm{Si}$ nuitopsis and bellerophontacean gastropods (Fig. 20) offers an attractive morphological series, although the Silurian Sylvestrosphaera is geologically too young to have filled this role phylogenetically (Peel, 1980a). The shape of the muscle scars in sinuitids, and in particular the composite form of the muscle scars in Sylvestropshaera, may suggest that these molluscs were untorted

Fig. 19. Muscle scars in the sinuitid Sylvestrosphaera lemchei Peel, 1980 and the bellerophontacean gastropod Megalomphala taenia (Lindström, 1884). A-G, Sylvestrosphaera lemchei, holotype, internal mould, OUM Geology, C. 16792, internal mould from the Late Silurian of Britain. A, detail of the muscle scar shown in $\mathrm{B}, \times 9 ; \mathrm{B}, \mathrm{C}$, lateral views with muscle scars, $\times 3$ and $\times 3.25$, respectively; $D$, as $C$ with muscle scar shaded, $\times 2.5 ; \mathrm{E}$, dorsal profile showing the broad anterior emargination and slightly constricted aperture, $\times 2.5$; F, posterior view showing muscle scars on each umbilical shoulder, $x$ $2.5 ; \mathrm{G}$, as $\mathrm{F}$ but with muscle scars shaded, $\times 2.5$. The use of anterior and posterior is based on the interpretation of Sylvestrosphaera as a gastropod. $\mathrm{H}-\mathrm{K}$, Megalomphala taenia, internal moulds from the Silurian of Gotland. H, MMH 13.037 in oblique antero-lateral view showing an elongate ridge associated with the muscle scar on the umbilical wall near the suture with the earlier whorl. A spiral ridge from the muscle scar in an earlier growth position is visible on the innermost visible whorl, $\times 1$. I-K, USNM 188177 in oblique lateral views showing similar ridges associated with musculature in the left (I) and right $(\mathrm{J}, \mathbf{K})$ umbilici, $\times 1$. whereas Bellerophon, with its single pair of muscle scars elongated concentric to the axis of coiling, was torted. The biomechanical advantages of reducing muscle attachment to a single area on each umbilical shoulder may be equally valid for retractile tergomyan and gastropod alike.

It might also be proposed that the deep placement of muscle scars in sinuitids is a gastropod character but the ability to retract has equal protective advantages for both coiled tergomyans and gastropods (Peel, 1980a), as confirmed by the description of deeply placed muscle scars in Sinuitopsis by Horny (in press a).

The dilemma that it may be impossible to distinguish coiled retractile tergomyans from bellerophontacean gastropods on the basis of the number and placement of muscle scars alone (Peel, 1980a) possibly may be resolved by employing other shell characters, such as the shape of the muscle scars. Horny (1990; in press a, b) pointed out differences in the morphology and method of relocation of muscle scars in cyrtonellid tergomyans and Bellerophon; he considered sinuitids to show greater similarity to Bellerophon on account of the gradual, non-saltating, relocation of muscle scars.

Other shell features cited in discussions of torsion in the bellerophontiform molluscs were reviewed by Harper \& Rollins (1982; see also Yochelson, 1967) who admittedly found most of them to be individually nondiagnostic (the similar quandary facing attempts to delimit the Gastropoda as a class on the basis of a single shell feature is well known and merely demonstrates the need for a less simplistic model). Features such as the dorso-lateral supposedly inhalant emarginations of trilobed bellerophontaceans (Peel, 1974, 1977b, 1978, 1984) and Knightites Moore, 1941 (Knight, 1952) are difficult to dismiss as indicators of gastropod affinities (see discussion below), although the location of inhalant 
currents in sessile, morphologically bell-shaped, bellerophontacean gastropods may reflect other influences. Similarly, Horny (in press, a) describes umbilical sinuses in Sinuitopsis strongly indicative of tergomyan affinities. Functional morphological analysis of the type employed by Linsley (1977, 1978), Linsley \& Peel (1983; see also Peel, 1974) and others offers a potential solution.

At the present time, the sinuitids are considered to be torted retractile molluscs and, as such, they are assigned to the Gastropoda, largely following arguments presented by Horny (1990; in press a, b). Sinuitids represent part of a morphological continuum (Fig. 20) and placement of the torsion event in this series is to some extent arbitrary - a situation reminiscent of the separation of the classes Helcionelloida and Rostroconchia, discussed below. Sylvestrosphaera out of the three sinuitid genera is less confidently assigned to the Gastropoda than Sinuites and Strangulites. This lack of confidence is based partly on the clearly composite nature of each umbilico-lateral muscle scar complex and the unusual, inflated, shape of the whorl profile (Fig. 19E). Sylvestrosphaera is also considerably younger than other described sinuitids with muscle scars but is unfortunately only known from a single specimen (Peel, 1980a).

\section{Tergomyan classification}

Peel (1991a) presented a severe diagnosis of the Class Tergomya, based exclusively on members of the Pilina and Tryblidium morphological group, in order to stress the conceptual difference between exogastric tergomyans and the endogastric Helcionelloida. Discussion of the scope of both classes below the class level was purposely omitted, apart from general discussion concerning placement of hypselloconellaceans and members of the Archinacella group, noted above. Transfer of the Order Cyrtonellida to the Class Tergomya (discussed above) and proposal of the new Order Hypseloconellida require emendation of the original diagnosis.

\section{Class Tergomya}

Diagnosis (emended). Generally bilaterally symmetrical molluscs in which the calcareous shell is usually planispirally coiled through about half a whorl to two or more whorls. The shell is often cap-shaped or ovoid, with an anterior apex which may vary from sub-central to overhanging the anterior margin; in other forms the shell may be a tall curved cone or coiled into a plane spiral with the coiled early growth stages carried ante-

\section{Class Tergomya}

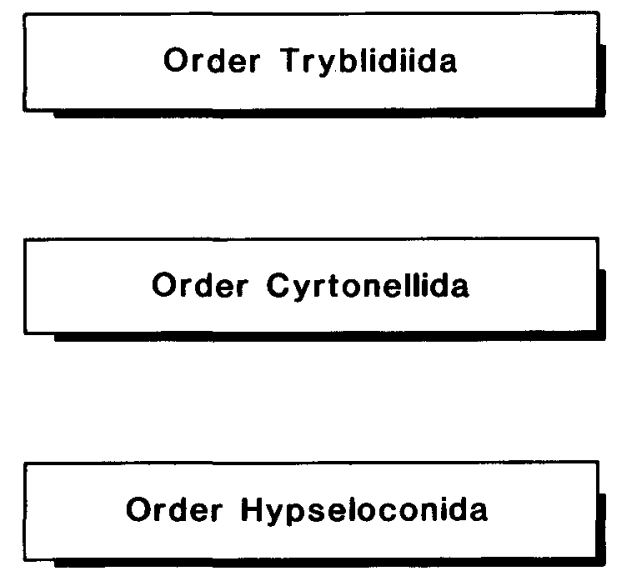

Fig. 21. Classification of the Class Tergomya.

riorly. The aperture is generally planar but may be slightly arched in lateral view in some cap-shaped forms (e.g., Pilina). Paired muscle scars on the shell interior of ovoid shells are typically grouped into a ring on the dorsal, supra-apical, surface with the apex lying outside of this ring. In strongly coiled shells and in unusually tall shells, paired muscle scars form a circle around the apex, varying in location from near the aperture to about half a whorl back from the apertural margins. Ornamentation consists of radial and/or comarginal elements; prominent comarginal rugae are not widely developed.

Discussion. At this time, three orders are recognised within the Class Tergomya (Fig. 21): Tryblidiida, Cyrtonellida and Hypseloconida (new).

\section{Order Tryblidiida Lemche, 1957}

This order includes those cap-shaped and ovoid shells related to Neopilina, Pilina and Tryblidium in which muscle scars are distributed in the tergomyan pattern of Horny (1965a, b; cf. Knight \& Yochelson, 1960, in part; Horny, 1963b, c; 1970; Figs 13, 20). Runnegar \& Jell (1976) placed the Archinacelloidea Knight \& Yochelson, 1958 within their concept of the Tryblidiida but Archinacella and its relatives are here considered to be gastropods (Starobogatov, 1970; Harper \& Rollins, 1982; Yochelson, 1988; Peel, 1990a). 


\section{Order Cyrtonellida Horny, 1963a}

The Order Cyrtonellida includes planispirally coiled shells (Fig 15D, 18D-F) such as Cyrtolites Conrad, 1838, Cyclocyrtonella Horny, 1962, Yochelsonellis Horny, 1962, Cyrtonella and Sinuitopsis Perner, 1903 (Horny, 1963a, 1965a, b; Rollins \& Batten, 1968; Rollins, 1969) in which several pairs of muscle scars form a circle around the shell, generally near to the aperture (Fig. 20). Starobogatov (1970) recognised an Order Sinuitopsida (alongside Orders Tryblidiida and Cyrtonellida) but this is here united with the Cyrtonellida. Runnegar \& Jell (1976; see also Runnegar \& Pojeta, 1985) placed the helcionelloids and hypseloconellaceans within their concept of Cyrtonellida while genera here regarded as members of the order were distributed between the Cyrtonellida and the Order Bellerophontida of their usage (most bellerophontidans are here considered to be gastropods).

The Orders Kirengellida Rozov, 1975 and Romaniellida Doguzhaeva, 1981 are not recognised and most of their genera are transferred to the Cyrtonellida.

\section{Order Hypseloconida (new)}

The Hypseloconida is diagnosed as containing tall, slightly coiled, cyrticonic shells which are interpreted as pseudo-endogastrically coiled by comparison with Knightoconus. The single Superfamily Hypseloconellacea Stinchcomb, 1986 includes the genera Hypseloconus, Knightoconus, Shelbyoceras Ulrich \& Foerste in Bridge, 1930 (cf. Stinchcomb \& Echols, 1966), Cambrioconus Stinchcomb, 1986, Cornuella Stinchcomb, 1986, Archeoconus Stinchcomb, 1986 and Yochelsonella Flower, 1968. Gasconadeoconus Stinchcomb, 1986 and Protoconus Stinchcomb, 1986 do not appear to be hypseloconids, although originally included within the Superfamily Hypseloconellacea by Stinchcomb (1986). The latter author placed his superfamily within the Order Archinacelloidea of the Class Monoplacophora but, as noted elsewhere, archinacelloids are considered to be gastropods.

\section{Class Helcionelloida}

Runnegar \& Pojeta (1974) viewed the univalved and bivalved molluscs as belonging to two sub-phyla for which they proposed the names Cyrtosoma and Diasoma (Fig. 5). In the Sub-phylum Cyrtosoma, the shell is usually univalved and the gut bent into a $U$-shape or twisted on account of torsion; this sub-phylum includes the classes Monoplacophora of their usage, Gastropoda and Cephalopoda. The gut is essentially straight in the Sub-phylum Diasoma and the shell may be univalved or bivalved. The classes Rostroconchia, Bivalvia and Scaphopoda were assigned to the Diasoma by Runnegar \& Pojeta (1974; see also Pojeta, 1980; Pojeta \& Runnegar, 1976; Runnegar, 1978, 1983; Runnegar \& Pojeta, 1985).

Runnegar \& Pojeta (1974) derived the sub-phylum Diasoma from a group of univalved molluscs termed helcionellaceans which they assigned to the Class Monoplacophora. As noted above, they included a variety of molluses within this class in addition to traditionally accepted monoplacophorans such as the tryblidiaceans Pilina, Tryblidium and the living Neopilina which Peel (1991a) placed within the Class Tergomya.

Runnegar \& Pojeta characterised helcionellaceans in terms of the genus Latouchella (Figs 9-11), although this group of Early and Middle Cambrian molluscs de- rives its name from Helcionella (Fig. 11). Helcionella is relatively more rapidly expanding and less strongly coiled than Latouchella.

In the Treatise on Invertebrate Paleontology Knight et al. (1960) placed helcionellaceans within the archaeogastropod Prosobranchia (Class Gastropoda) but Runnegar \& Pojeta (1974) followed contemporary authors in considering helcionellaceans to be untorted molluscs. As with the tryblidiaceans (= Class Tergomya of present usage), Runnegar \& Pojeta considered the helcionellaceans to be exogastrically coiled, i.e. the apex of the coiled shell was located anteriorly and the shell expanded posteriorly. Thus, the generally concave subapical surface was located anterior of the apex while the convex supra-apical surface was posterior (Fig. 12A).

Peel (1991a) considered that helcionellaceans represented a major lineage of untorted univalved molluses distinct from the Tergomya and established a new class, the Class Helcionelloida. Peel considered helcionelloids to be endogastrically coiled (Fig. 12B), as suggested by Yochelson (1978; 1979), Geyer (1986) and Peel \& Yochelson (1987), and thus distinct from the exogastric Tergomya. This conclusion was supported by interpretation of morphological features of the helcionelloid shell in terms of functional adaptation. The shell apex was 
considered to be posterior and the shell expanded anteriorly in the Helcionelloida, as is the case also with the gastropods. Unlike gastropods, however, helcionelloids are interpreted as untorted molluscs.

\section{Order Eomonoplacophora}

In a recent publication, not available to Peel (1991a), Missarzhevsky (1989) proposed Eomonoplacophora to contain Helcionella and its relatives, in a summary of Soviet Lower Cambrian helcionelloids. Missarzhevsky cited the importance of knowledge of muscle scars in classifying taxa within the Class Monoplacophora of his usage, approximately the Class Tergomya of this paper. He criticised Runnegar \& Jell (1976) for only employing gross morphology as the basis for much of their classification, quoting as an example the unfortunate placement of Protowenella Runnegar \& Jell, 1976, Multifariites Bjalyi, 1973 and Bellerophon within the same supposedly monoplacophoran order. Missarzhevsky placed Bellerophon with the gastropods, Multifariites with the Monoplacophora (= Tergomya) but found no conclusive evidence as to where he should place Protowenella.

Missarzhevsky (1989, p. 22) recommended that Monoplacophora should be restricted to those forms in which muscle scars clearly indicated this systematic position. He proposed Eomonoplacophora as an informal group of undefined systematic range to include Cambrian shells of monoplacophoran aspect but without preserved muscle scars. He defined several families on general morphological grounds.

Missarzhevsky expressed his conviction that Eomonoplacophora followed the general monoplacophoran body plan and were not gastropods. He suggested that muscle scars were not known in Eomonoplacophora on account of muscle insertion into an epithelial layer rather than directly to the shell. He considered direct muscle attachment to the shell to be a later evolutionary development in molluscan evolution.

Later in the same work, Missarzhevsky $(1989$, p. 171) formally erected Eomonoplacophora as a new order of the Class Monoplacophora.

Missarzhevsky interpreted members of the Eomonoplacophora as exogastric, in keeping with the placement within the Class Monoplacophora. Thus, he considered emarginations in the apertural margin of the concave sub-apical surface to be anterior and those in the supra-apical surface to be posterior (cf. Missarzhevsky, 1989, fig. 6). Following Runnegar \& Pojeta (1974), the snorkel in Yochelcionella was also interpreted as anterior by Missarzhevsky (1989).

While Missarzhevsky's recognition of the integrity of the helcionelloids is to be applauded, his interpretation of the group as exogastric can not be sustained. In consequence, the term Eomonoplacophora is not employed even though its generic content (but not its concept) corresponds quite closely to that of the Class Helcionelloida. Concept apart, it would also be confusing to maintain Eomonoplacophora for the present endogastric Helcionelloida after purposely replacing the exogastric Monoplacophora with Tergomya.

\section{Classification of helcionelloids}

Two recent classifications of helcionelloid genera are available, but both view helcionelloids in different conceptual frameworks than that expounded here.

Runnegar \& Jell (1976) assigned the families Helcionellidae, Scenellidae, Palaeacmaeidae, Yochelcionellidae, Procarinariidae, Hypseloconidae and Cyrtolitidae to their Superfamily Helcionellacea of the Order Cyrtonellida, Class Monoplacophora. Procarinariidae was replaced by the new family name Stenothecidae by Runnegar \& Jell (1980) for the same group of genera (Anabarella Vostokova, 1962; Mellopegma Runnegar \& Jell, 1976, Stenotheca Hicks, 1872), but excluding the bivalve Procarinaria Perner, 1911.

Runnegar \& Jell (1976) commented that the Palaeacmaeidae may not be untorted molluses and this family does not appear in the list of helcionellacean families subsequently published by Runnegar \& Pojeta (1985). Yochelson \& Stanley (1981) interpreted Palaelophacmaea Donaldson, 1962, placed in the Family Palaeacmaeidae by Runnegar \& Jell (1976), as a coelenterate (Hydrozoa).

In the present classification, the endogastric Helcionellacea and the exogastric Cyrtonellida are referred to separate classes (respectively Helcionelloida and Tergomya), in direct conflict with the classifications of Runnegar \& Jell (1976) and Runnegar \& Pojeta (1985). Thus, the Helcionellacea as recognised here is removed from the Cyrtonellida and does not contain the Family Cyrtolitidae which Runnegar \& Jell (1976) placed here, although Runnegar \& Pojeta (1985) placed it within another monoplacophoran order of their usage, Bellerophontida. Cyrtolitidae and Hypseloconidae are here considered to be Tergomya, although the latter family was also assigned to the Helcionellacea by Runnegar \& Jell (1976) and Runnegar \& Pojeta (1985).

The Scenellidae of Runnegar \& Jell (1976) contains a variety of cap-shaped shells of moderate height ranging in age from Early Cambrian to Early Ordovician. The description of well preserved muscle scars in a specimen assigned to Scenella Billings, 1872 by Rasetti (1954) is of potentially great interest to interpretations of musculature in the Helcionelloida, as noted by Runnegar \& Jell 
(1976) and Runnegar \& Pojeta (1974). However, the status of Rasetti's specimens both as members of Scenella and the Class Helcionelloida remains problematic. Yochelson \& Gil-Cid (1984) suggested that Scenella was a chondrophore; this opinion is not endorsed although the status of many species assigned to the genus (also the genus Marocella Geyer, 1986) is problematic.

The systematic position of several Late Cambrian and Early Ordovician genera from the Soviet Union, Kirengella Rozov, 1968, Lenaella Bjalyi, 1973, Moyerakania Rozov, 1970 and Romaniella Doguzhaeva, 1972, which Runnegar \& Jell (1976) assigned to the Scenellidae, remains uncertain; they appear to be tergomyans in which the muscle scar patterns reflect the relatively high, strongly coiled shell. Peel (1988b) described material from the late Middle Cambrian of Peary Land, North Greenland, which he assigned to Kirengella (inadvertently spelt Kiringella in perpetuation of an error in the American translation of Rozov's paper of 1968) within the Superfamily Hypseloconellacea (now order Hyseloconida of the Tergomya). Interestingly, Doguzhaeva (1981) interpreted Romaniella as endogastric on the basis of a shallow sinus in the sub-apical surface which she considered to indicate the location of the anus. Doguzhaeva placed Romaniella in a new Order Romaniellida of the Monoplacophora, pointing out its great similarity with Latouchella.

The helcionellids, yochelcionellids and stenothecids of Runnegar \& Jell (1976) and Runnegar \& Pojeta (1985) are readily retained within the Class Helcionelloida.

Missarzhevsky (1989, pp. 23-24 and table 2) recognised eight families of Eomonoplacophora for Soviet Lower Cambrian helcionelloids, five of which were new. Missarzhevsky (1989) employed a finer division that that employed by Runnegar \& Jell (1976) and Runnegar \& Pojeta (1985), although Helcionellidae and Yochelcionellidae are maintained. Mellopegmidae is proposed as a new family to contain Mellopegma and Isitella Missarzhevsky, 1989. The former genus was placed within the Stenothecidae by Runnegar \& Jell (1980) together with Anabarella which Missarzhevsky (1989) placed within the Family Coreospiridae Knight, 1952; Runnegar \& Jell (1976) placed Coreospira Saito, 1936 within their Helcionellidae! Missarzhevsky (1989) recognised the affinity of Protowenella Runnegar \& Jell, 1976 with the helcionelloids, endorsed here (see discussion below), while Runnegar \& Pojeta (1985) had assigned it to their Order Bellerophontida of the Class Monoplacophora.

No sub-division of the Class Helcionelloida is presented here. It is stressed that a number of the Late Cambrian and Early Ordovician fossils variously re- ferred to the Monoplacophora and bellerophontiform Mollusca (as both Monoplacophora and Gastropoda, or both) in published literature may be members of the classes Tergomya, Gastropoda and possibly Helcionelloida.

\section{Functional morphology of the Class Helcionelloida}

Morphological features of the shell aperture in the Class Helcionelloida, such as emarginations and the presence in some forms of a snorkel, support the reconstruction of an essentially posterior mantle cavity in an endogastric shell. The mantle cavity was probably located posteriorly, essentially beneath the sub-apical surface. Water currents usually entered the mantle cavity laterally, passing over postero-laterally arranged gills prior to leaving the mantle cavity as a single, median posterior stream (Peel, 1991a; Fig. 12B; see also discussion of size in functional morphological interpretation, above).

The shell in Helcionella is low, and ovoid in plan view, reminiscent of tryblidiacean tergomyans such as Pilina and Neopilina, although these are commonly several times larger. While considered to be endogastric (contra the exogastric tergomyans) Helcionella may have possessed a mantle cavity extending along the lateral surfaces (Fig. 22).

In strongly coiled and lateral compressed helcionelloids such as Latouchella, the mantle cavity was probably concentrated in the posterior portion of the shell in similar fashion to its more restricted distribution in the gastropods and cephalopods, due to life in the narrow cone-like shell. This reduction of the mantle cavity, and possibly also a concomitant reduction in the number of pairs of gills relative to Helcionella, probably also occurred in hypseloconellacean tergomyans such as Hypseloconus and Knightoconus.

\section{The mantle cavity in Latouchella}

Robison (1964) reported longitudinal ridges on the interior of the sub-apical surface of Latouchella in silicified specimens from the Middle Cambrian of the western United States. Runnegar \& Jell (1976) described similar material in a size range of 1 to $5 \mathrm{~mm}$ from the Middle Cambrian of Australia, some of which is described here (Fig. 23).

Phosphatic internal moulds (length 1-2 mm) of $L a$ touchella described here from the Middle Cambrian Henson Gletscher of Peary Land, central North Greenland preserve deep grooves on the sub-apical surface, corresponding to the internal ridges of the silicified 

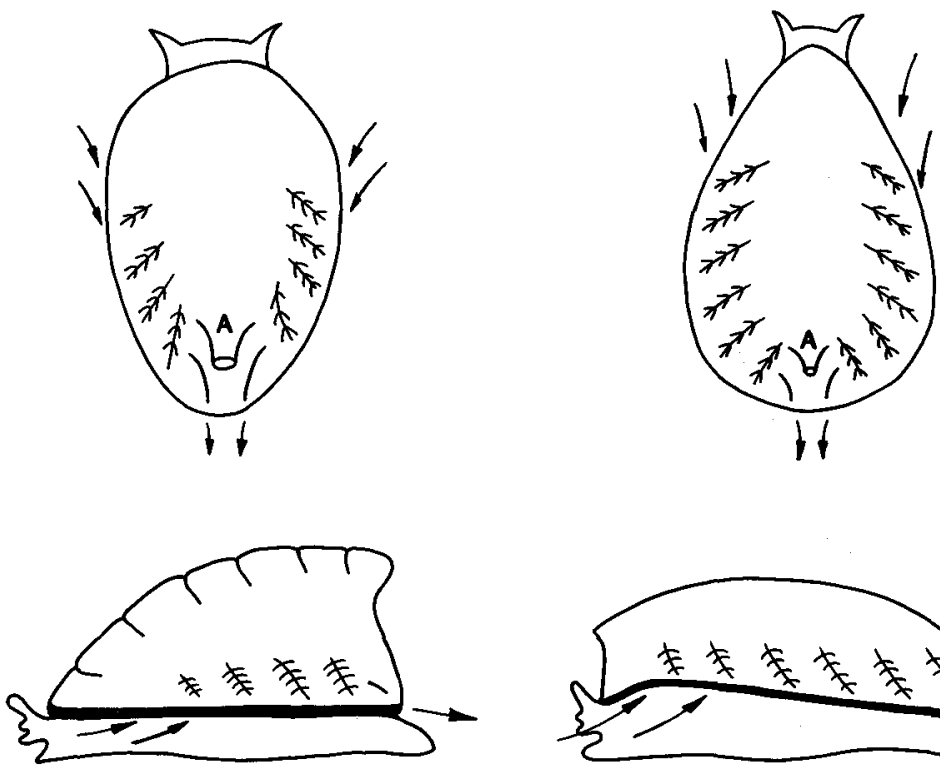

Helcionella

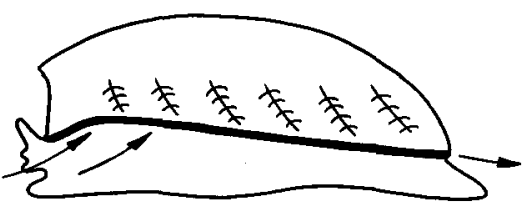

Pilina
Fig. 22. Reconstructions of the mantle cavity in Helcionella and a tryblidiacean tergomyan such as Pilina. Both molluscs are drawn in dorsal and lateral views. There is no direct evidence as to the number of pairs of gills present in Helcionella but the form of the shell suggests that the mantle cavity may have extended relatively far forward when compared to more strongly coiled helcionelloids such as Latouchella. Pilina is restored with six pairs of gills; inhalant currents enter the shell anterolaterally by way of pronounced emarginations (cf. Fig. 2D). Thick black line, apertural margin; $\mathrm{A}$, anus. material (Fig. 24). The grooves are not present at the earliest growth stages, although subsequent deposition of calcium carbonate on the shell interior may have obscured their presence.

The grooves are arranged symetrically in pairs about the median plane of symmetry (Fig. 24A, D); as few as a single pair and as many as three pairs have been observed. In the latter case, the inner pair originates nearer to the shell apex while the outer pairs commence more distally (Fig. 24D-G), although this may not be a result of simple ontogenetic increase in the number of ridges. The individual ridges responsible for producing the grooves on the shell interior are not necessarily entire but may be periodically interupted (Fig. 24D-G).

The silicified material from Australia (Fig. 23) shows the ridges terminating just within the aperture; the shape of the structures in cross-section is well-rounded, not acute, with a tendency to be T-shaped (Fig. 23C).

The ridges reflect folds in the overlying soft-tissue of the mantle cavity wall and probably served to separate lateral inhalant water currents from a median exhalant stream. This mantle cavity configuration is similar to that described in the bellerophontacean gastropods Plectonotus Clarke, 1899 and Tritonophon Öpik, 1953 by Peel $(1974 ; 1984$; see also the description of Knightites Moore, 1941 by Knight in Moore, 1941 and Knight, 1952). In Plectonotus and Tritonophon, which range in length from about 1 to $3 \mathrm{~cm}$, conspicuous trilobation of the dorsal area (Fig. 25) reflects separation of the two lateral inhalant currents from the median exhalant cur- rent (Fig. 26). The degree of trilobation in many large specimens of Plectonotus is so great that internal moulds are often marked by deep spiral channels separating the three dorsal lobes (Peel, 1974; Fig. 25).

The mantle cavity within the dorsally trilobed Plectonotus and Tritonophon probably contains a pair of laterally disposed gills, by analogy with primitive gastropods (Knight, 1952; Peel, 1974, 1977b, 1984; Fig. 26). While the presence of as many as three pairs of ridges in Latouchella might conceivably suggest that a corresponding number of pairs of gills was present, the narrowness of the shell, variation in the number of ridges and the presumably restricted size of the mantle cavity argue against this interpretation. It should be noted, however, that multiple gills are sometimes present in the small posterior mantle cavity of polyplacophorans (cf. Smith, 1960; Yonge, 1960).

The silicified specimens of Latouchella from Australia show no trace of a median emargination in the apertural margin of the sub-apical surface, although such an emargination is conspicuous in many helcionelloids (Runnegar \& Jell, 1976; see also Figs 9-11) and also in the dorsal apertural margin of plectonotiform gastropods (Figs 25, 26).

Silicified specimens of Latouchella with well-preserved apertural margins may show shallow lateral emarginations associated with a tendency for the aperture to become keyhole-shaped (Fig. 23C, D, F-H). The lateral impression of the apertural margins producing the narrower waist in this keyhole-shape in apertural 

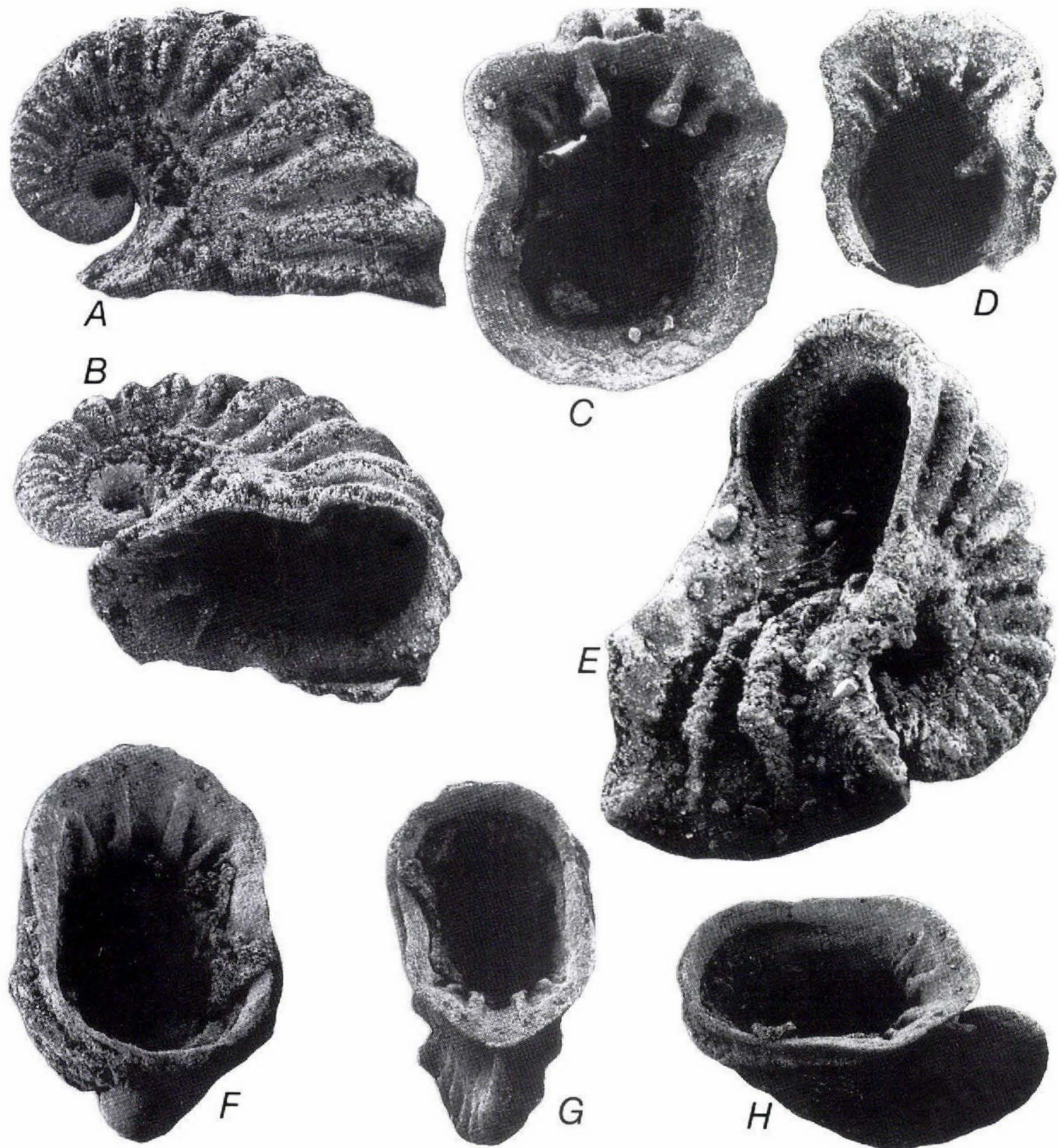

Fig. 23. Internal ridges in the helcionelloid Latouchella controlling water currents in the posterior mantle cavity. Silicified replicas of Latouchella merino Runnegar \& Jell, 1976 from the Middle Cambrian Coonigan Formation, New South Wales, Australia, Australian National University Bulk Collection 10352 (see Runnegar \& Jell, 1976, p. 110), showing ridges on the sub-apical wall. A, B, MGUH 19.557 in lateral and aperturo-lateral views showing two pairs of ridges within the aperture. The prominent comarginal rugae on the shell exterior are restricted to the dorso-lateral areas of the shell, leaving the umbilico-lateral areas smooth. The adumbilical termination of the individual comarginal rugae corresponds with the constriction in the aperture producing the key-hole shape seen in C and D, $\times 10 . \mathrm{C}, \mathrm{MGUH} 19.559$ in apertural view showing the key-hole shape of the aperture and the bulbous thickening of the crests of the two pairs of ridges on the sub-apical wall, $\times 10 . \mathrm{D}, \mathrm{MGUH} 19.556$ in apertural view, as last, $\times 10$. E, MGUH 19.558, oblique lateral view of broken specimen showing the ridges on the interior of the sub-apical wall extending deep into the shell interior, $\times 15$. F-H, MGUH 19.560 in various apertural views to show the two pairs of internal ridges and the shallow sinus in the lower right of the apertural margin in $\mathrm{H}, \times 7$. 

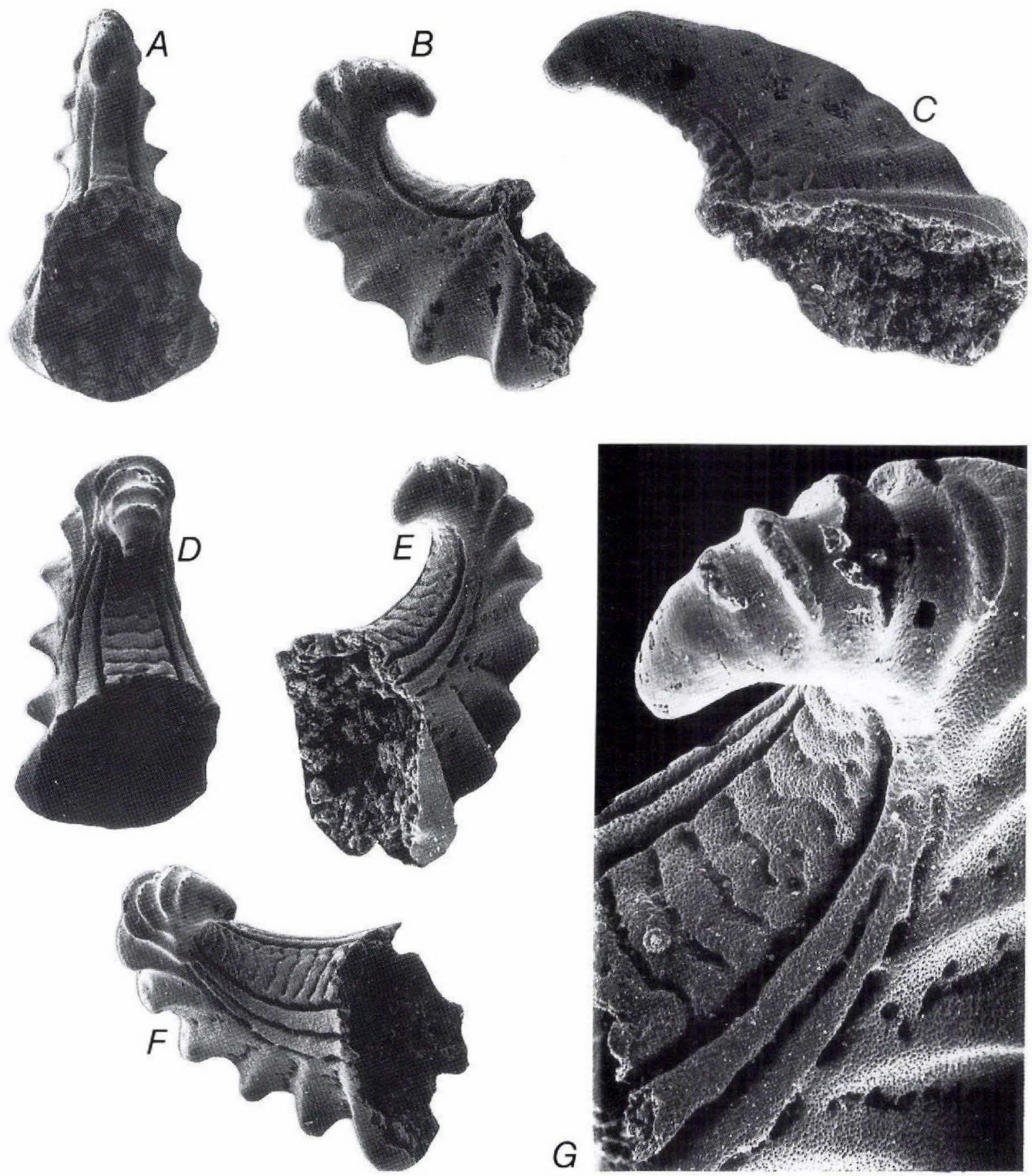

Fig. 24. Internal moulds of the helcionelloid Latouchella showing furrows produced by ridges on the shell interior. The ridges control water currents in the posterior mantle cavity. A-G, Latouchella spp., late Middle Cambrian, Henson Gletscher Formation, Løndal, Peary Land, central North Greenland, GGU collection 271718, internal moulds. A, B, MGUH 19.562, posterior and oblique lateral views showing a single pair of grooves on the sub-apical surface of the internal mould representing ridges on the shell interior, $\times 30$. C, MGUH 19.563, oblique lateral view of a second species of Latouchella showing one of a pair of grooves on the internal mould corresponding to a ridge on the shell interior, $\times 50$. D-G, MGUH 19.561, oblique posterior views of the sub-apical surface showing three pairs of ridges preserved as furrows in the surface of the internal mould, $\times 30$. Note that the outer pair of ridges is discontinuous $(\mathrm{G}, \times 85)$. 
Fig. 25. Silurian plectonotiform bellerophontacean gastropods showing the development of dorsal trilobation as an adaptation to enhance separation of inhalant and exhalant currents within the mantle cavity. A, Plectonotus boucoti Peel, 1974 from near Llandeilo, Wales, U.K., NMW $39.180 \mathrm{G14}, \times 3$. The medial dorsal selenizone is generated by a short slit representing the point of exit of the exhalant stream; inhalant streams enter the mantle cavity antero-laterally under the flanking folds. B, Plectonotus boucoti Peel, 1974, internal mould, Doctors Brook Formation, Nova Scotia, USNM 169590, × 2. C-E, Plectonotus boucoti Pecl, 1974, internal mould, Tonlegee, Cong, Ireland, SM A39164 (C, E) and SM A39165 (D), × 2. F, Tritonophon kivitalonae Peel, 1974, internal mould, Stonehouse Formation, Nova Scotia, GSC 32782, × 2. G, Tritonophon trilobata (Sowerby, 1839), internal mould, Moydart Formation, Nova Scotia, USNM $169594, \times 3$.

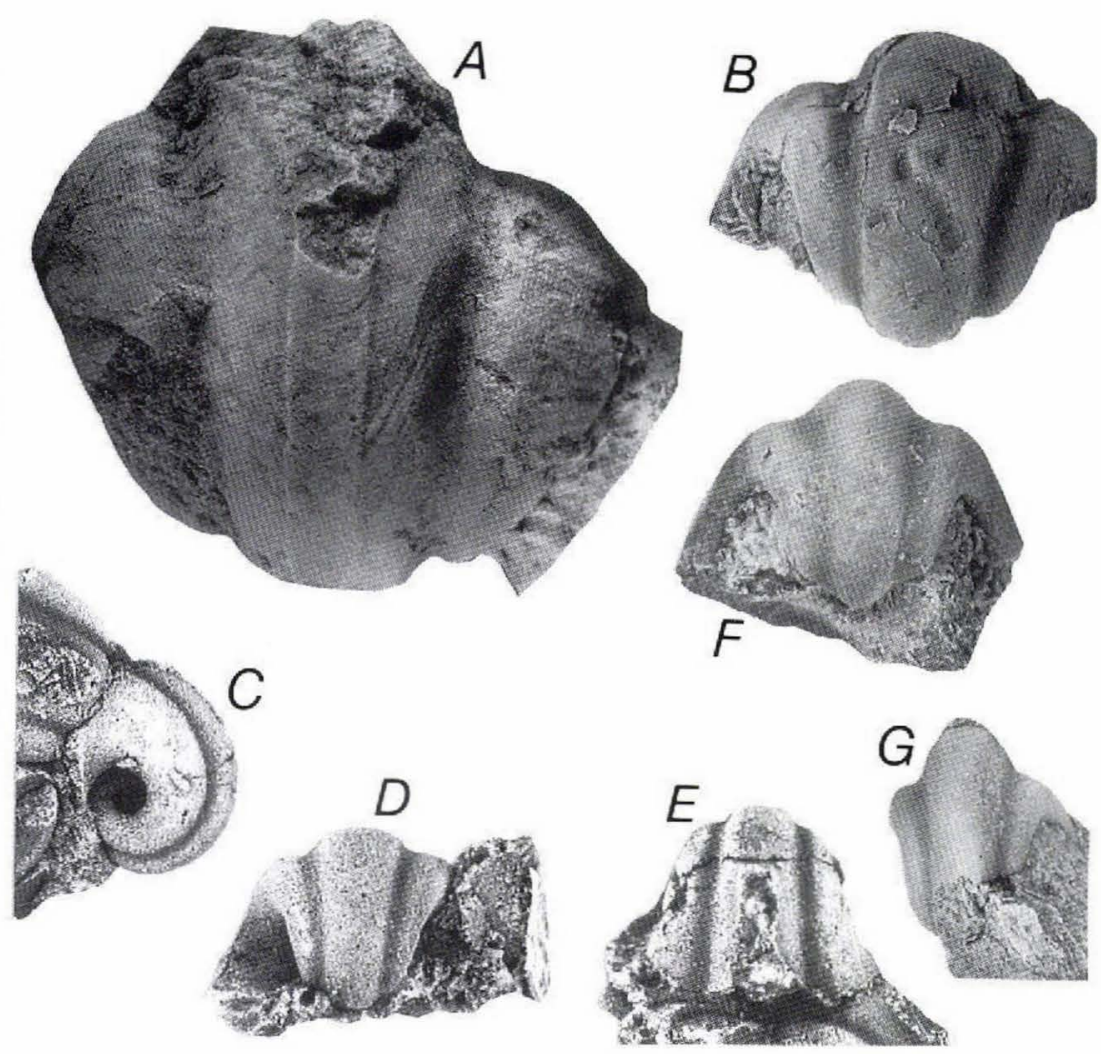

view corresponds to the sudden termination of the prominent comarginal rugae of the supra-apical surface against the essentially unornamented sub-apical surface, when the shell is viewed laterally (Fig. 23A, B).

The keyhole-shape of the aperture suggests that the mantle cavity was located in the area between the narrow waist and the apertural margin of the sub-apical surface, an interpretation supported by the location of the shallow lateral emarginations at the narrow waist. The keyhole-shape may represent incipient separation of an antero-ventral aperture from the more posteriorly located mantle cavity interpreted elsewhere in this discussion as present in Yochelcionella, Eotebenna and Eurekapegma.

Runnegar \& Jell (1976, p. 127) suggested that the ridges on the interior of the sub-apical wall in Latouchella formed an anterior inhalant channel in the exogastrically oriented shell. Following the model of Runnegar \& Pojeta (1974), this interpretation would require that the inhalant current divided along either side of the body mass as it passed over laterally arranged respiratory surfaces, and that exhalant streams left the mantle cavity along each lateral surface (cf. Pojeta \& Runnegar, 1976, fig. 9B; see also Fig. 12A). This orientation is opposite to that accepted here, where inhalant currents are believed to have entered the endogastric shell laterally or postero-laterally and to have united prior to exhalation as a single median, posterior stream (Fig. 12B).

The internal ridges in Latouchella probably reflect mantle cavity folds which helped to separate these lateral inhalant currents from the posterior exhalant stream. Oxygen-rich water entered the mantle cavity along two relatively wide surfaces, achieving maximum supplies for respiration. The force of expulsion of the exhalant current would be increased by the unification of the two lateral inhalant streams, thus carrying oxygen-depleted water away from the shell.

The internal ridges in Latouchella can be discussed in terms of a number of other functions, but these are considered unsatisfactory. A possible role as supports for shell muscle attachment is rejected due to the positive relief of the ridges within the shell interior and their persistence to the apertural margin. Muscle scars are usually impressed into the shell and therefore raised on the internal mould (cf. Horny, 1965a; Peel, 1972, 1976, 1977a, 1980a, 1982; see Figs 1, 18D-F, 19). Longitudinal ridges and other structures are often associated with 

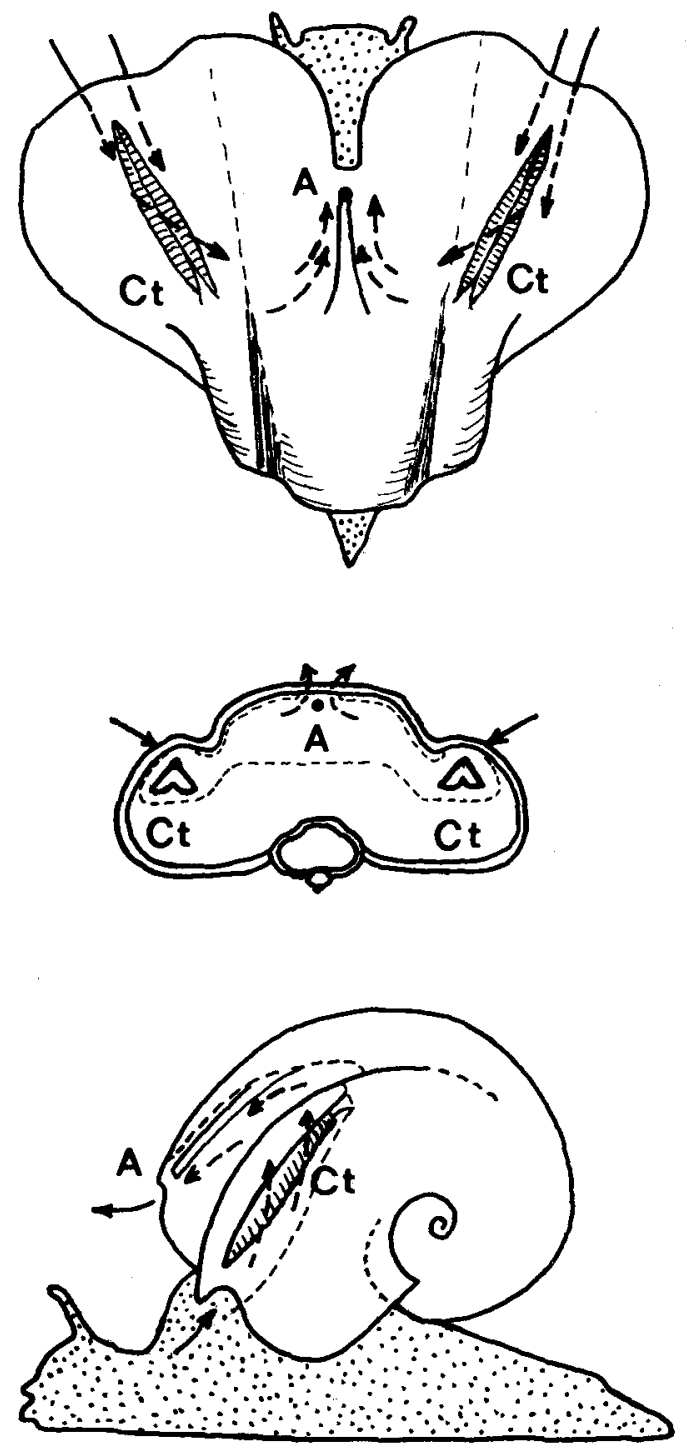

Fig. 26. Reconstruction of the mantle cavity in Plectonotus boucoti Peel, 1974, seen in dorsal, transverse and lateral aspects. Water currents entering the shell beneath the flanking lobes pass over the gills $(\mathrm{Ct})$ prior to expulsion through the median dorsal slit. A, anus (after Peel, 1974).

muscle scars in bellerophonts and gastropods (cf. Peel, 1977a, 1982; Fig. 19) but these show little similarity to the prominent internal ridges described here.

An hypothesis that the ridges may have controlled mantle folds in association with retraction of soft parts into the shell is also rejected. On account of the rapid rate of expansion of the shell and the planar aperture suited to clamping against the substrate, there is little reason to suggest that these helcionelloids were capable of substantial retraction into the shell.
Many gastropods develop columellar folds reminiscent of the structures in Latouchella. Signor \& Kat (1984) reported a high degree of correlation between such folds and the burrowing habit in living high-spired gastropods, enabling the recognition of this mode of life in high-spired gastropods at least as old as Silurian (Peel, 1984). However, there is little in the location of the ridges or the form of the shell in Latouchella to suggest that the ridges performed the muscle-control function documented by Signor \& Kat (1984).

The shell aperture in some living terrestrial pulmonate gastropods and a number of marine gastropods is constricted by lamellae or palatal folds which are often attributed a defensive function; the folds may also strengthen the outer lip against breakage by predators. The ridges described in Latouchella morphologically resemble these apertural lamellae and folds but their distribution on the sub-apical surface is far too restricted to serve the same function.

In conclusion, the spiral ridges in Latouchella are interpreted as controlling mantle folds associated with increasing mantle cavity efficiency. Their presence on the sub-apical surface of the laterally compressed shells is construed as evidence for a posterior location. Hence, shell coiling is believed to be endogastric.

\section{The function of the snorkel in Yochelcionella}

Yochelcionella Runnegar \& Pojeta (1974) has been described from Lower and Middle Cambrian strata throughout the world (Berg-Madsen \& Peel, 1987; Geyer, 1986; Runnegar \& Jell, 1976; Missarzhevsky \& Mambetov, 1981; Pei, 1985; Peel, 1988a, 1991a; Runnegar \& Pojeta, 1980; Voronova et al., 1987). In Greenland, Yochelcionella is abundant in the Paralleldal Formation of latest Early Cambrian age, but it also occurs in the slightly older Henson Gletscher Formation (Peel, $1980 \mathrm{~b}$ and unpublished observations). Species of $\mathrm{Yo}$ chelcionella vary in form from strongly curved and laterally compressed (such as Yochelcionella americana Runnegar \& Pojeta, 1980; see also Peel, 1988a and Fig. 27 herein) to tall and slender cones such as Yochelcionella ostentata Runnegar \& Jell, 1976. The characteristic snorkel is developed on the sub-apical surface in all species.

Pojeta \& Runnegar (1976, fig. 9) discussed the function of the snorkel in Yochelcionella suggesting four possible reconstructions summarised in Fig. 28. In accordance with their earlier model of molluscan evolution (Runnegar \& Pojeta, 1974), they concluded that the shell of Yochelcionella was exogastrically coiled with the anterior snorkel serving as a conduit for water entering the mantle cavity (Fig. 28A). The inhalant current 
Fig. 27. Yochelcionella amer icana Runnegar \& Pojeta, 1980, late Early Cambrian, Forteau Formation, Gros Morne, western Newfoundland, Canada, phosphatic internal moulds. A, dorsal view, GSC $85863, \times 45$. B, GSC 85862 in lateral view showing the prominent snorkel located posteriorly, on the sub-apical surface, $\times 45$. C, GSC 85864, as last, $\times 55$. D, GSC 85865 , as last, $\times 45$.

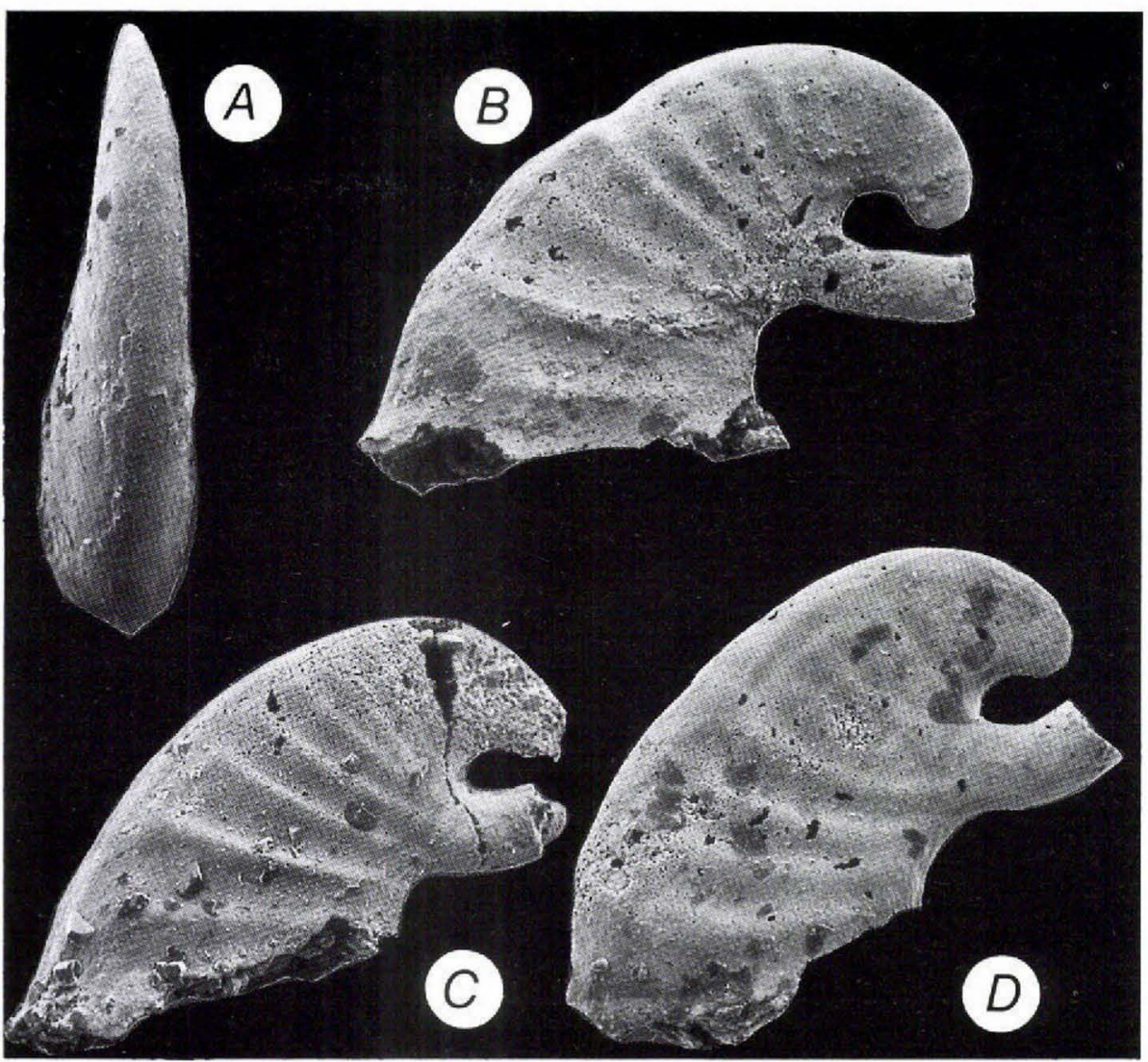

subsequently divided prior to passing over the laterally located respiratory surfaces; exhalant currents left the mantle cavity along each postero-lateral surface. This interpretation was refuted by Yochelson (1978), Geyer (1986), Peel \& Yochelson (1987; see also Berg-Madsen \& Peel, 1987) and Peel (1991a) who considered that the posteriorly located snorkel in the endogastrically coiled shell contained the exhalant stream from the mantle cavity (Fig. 28B, but see discussion of size in functional morphological interpretations, above).

The mantle cavity in Yochelcionella is considered to be mainly restricted to the posterior region of the shell, particularly in those species with relatively narrow, cone-shaped shells. Oxygen-rich water enters the mantle cavity along two relatively wide postero-laterally surfaces, providing maximum supplies for respiration. Unification of the two lateral streams and concentration of the single exhalant current in the narrow snorkel carries oxygen-depleted water away from the shell.

Interpretation of the snorkel as the conduit for the inhalant current, as suggested by Pojeta \& Runnegar (Fig. 28A), restricts intake of oxygenated water to a single narrow stream which is diminished further by being divided into streams passing along each side of the mollusc. Thus, the narrowness of the snorkel in the model of Pojeta \& Runnegar (1976) inhibits the supply of oxygenated water to the mantle cavity while this same narrowness in the reconstruction favoured by Peel (1991a) is interpreted as an adaptation to carry oxygendepleted water away from the mantle cavity.

Some infaunal bivalves employ a narrow siphon for both inhalation and exhalation and this dual function is also ascribed to presumed sessile species of Yochelcionella and Eotebenna, as discussed below. However, the majority of species of both these taxa appear to be active members of the epifauna. As with modern epifaunal gastropods and some protobranch bivalves, a stream of water through the mantle cavity offers better water supply.

\section{Snorkel development in Eotebenna}

Eotebenna was originally described on the basis of two species from the Middle Cambrian of Australia (Runnegar \& Jell, 1976). Peel (1989; 1991a) has described a Lower Cambrian species (length about $4 \mathrm{~mm}$ ) from the Henson Gletscher Formation of Freuchen Land, central North Greenland and a late Middle Cam- 

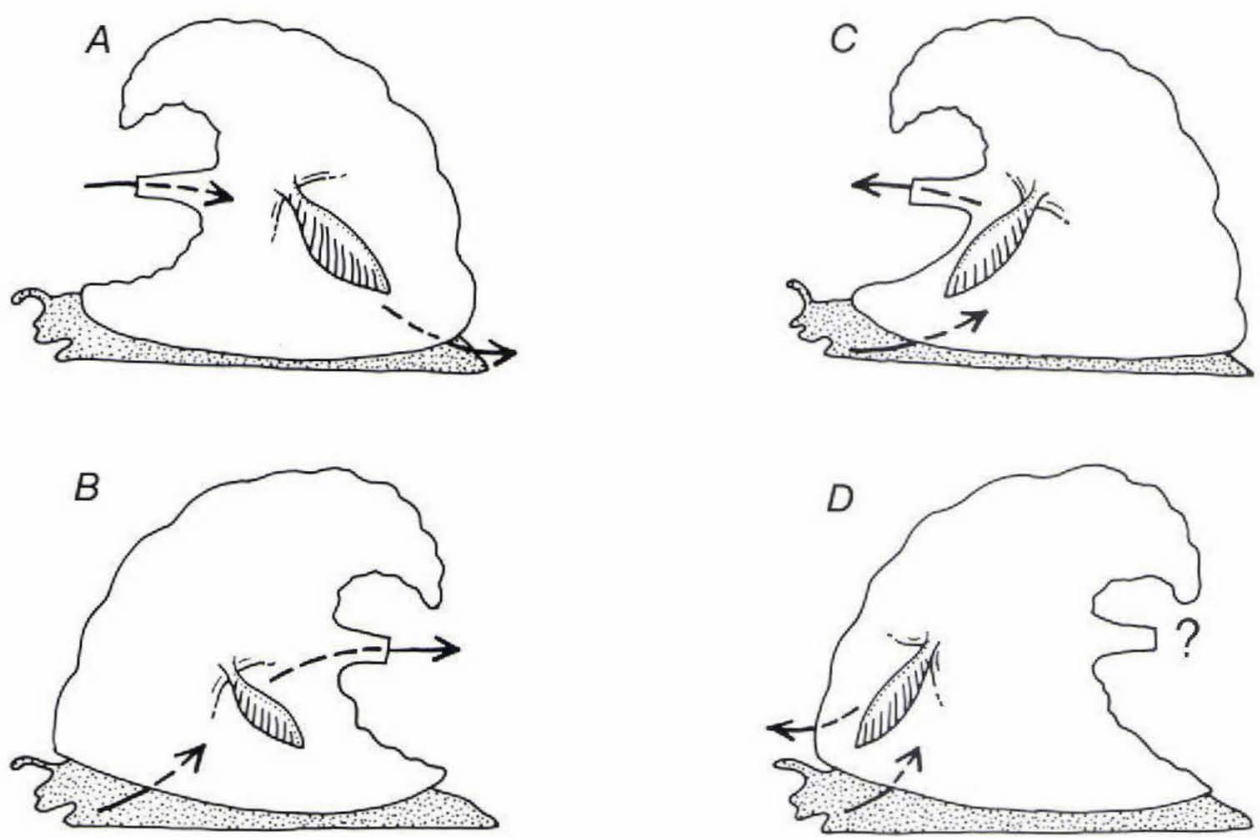

Fig. 28. Possible reconstructions of Yochelcionella. A, Yochelcionella interpreted as an exogastric untorted mollusc (same shell orientation as Tergomya) in which the the single inhalant current enters the mantle cavity through the snorkel and divides to pass over the laterally disposed gills prior to postero-lateral exhalation. This is the reconstruction favoured by Runnegar \& Pojeta (1974 and subsequent papers) which is rejected here. B, Yochelcionella interpreted as an endogastric untorted mollusc (helcionelloid) with water currents entering the mantle cavity laterally and passing over the gills prior to expulsion as a single median stream through the posterior snorkel. This is the reconstruction favoured by Geyer (1986), Peel \& Yochelson (1987) and Peel (1991a) and adopted herein. C, Yochelcionella interpreted as an exogastric gastropod. Water currents enter the mantle cavity antero-laterally and are exhaled through the anterior snorkel; gastropods, however, are typically endogastric and this restoration is rejected. D, Yochelcionella interpreted as an endogastric gastropod. Water currents enter the mantle cavity antero-laterally and are expelled anteriorly; the posterior snorkel has no obvious function in terms of respiration. This interpretation is also rejected here (modified after Pojeta \& Runnegar, 1976).

brian species from the Andrarum Limestone of Bornholm, Denmark (Figs 29-31).

Missarzhevsky (1989, pl. 31, fig. 6) assigned to Eotebenna an Early Cambrian (Botomian) species from
Central Asia, originally described as Yochelcionella recta Missarzhevsky in Missarzhevsky \& Mambetov, 1981. The specimen is only illustrated in lateral view, making interpretation difficult. There is at least super-
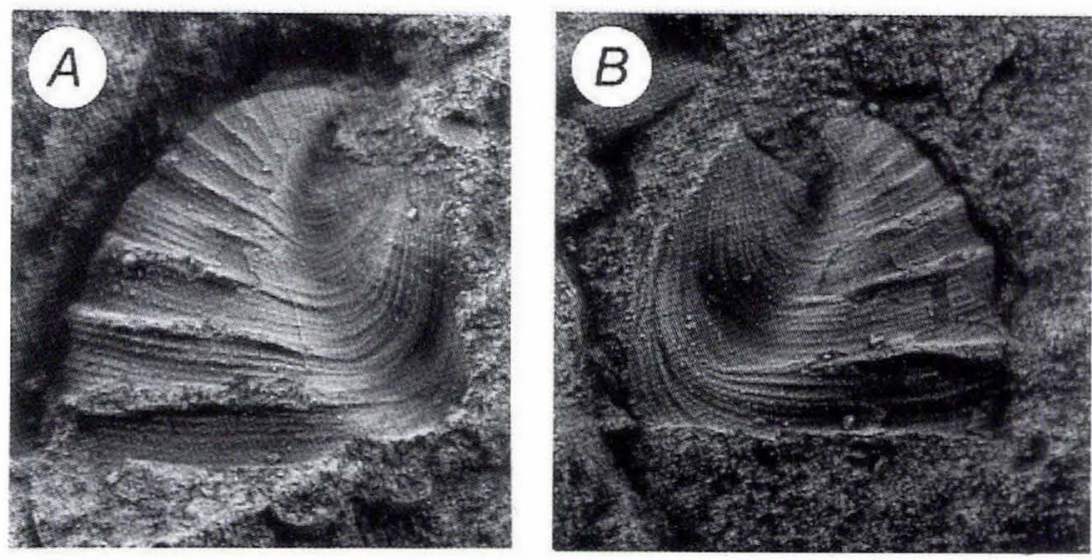

Fig. 29. Eotebenna arctica Peel, 1989 from the late Early Cambrian Henson Gletscher Formation, south-east Freuchen Land, central North Greenland, GGU collection 315109 , $\times$ 10. A, MGUH 18.702, lateral view with anterior to left. B. MGUH 18.701 , lateral view with anterior to right. Note the prominent sail-like snorkel-fold on the sub-apical surface. 
ficial resemblance to Eotebenna pontifex Runnegar \& Jell, 1976 from the Middle Cambrian of Australia but it is not immediately apparent from the illustration why this unusual species was rejected from Yochelcionella.

Eotebenna is also characterised by the development of a snorkel but it differs from Yochelcionella in that the small perforation at the distal end of the snorkel is usually connected to the shell aperture by a narrow slit. Thus, the snorkel in Eotebenna more closely resembles a deep fold in the sub-apical apertural margin rather than a discrete tube, and the genus may be considered as a morphological intermediate between species of $\mathrm{La}$ touchella with an apertural fold beneath the apex and Yochelcionella (Fig. 11).

The snorkel in Eotebenna is considered to lie posteriorly and to contain the exhalant current from the mantle cavity, as in Yochelcionella. The shell aperture is antero-ventral; this is also the orientation proposed for the aperture in rostroconchs by Pojeta \& Runnegar (1976) and Pojeta $(1980 ; 1987)$, although their interpretation of Eotebenna would place the aperture posteroventrally.

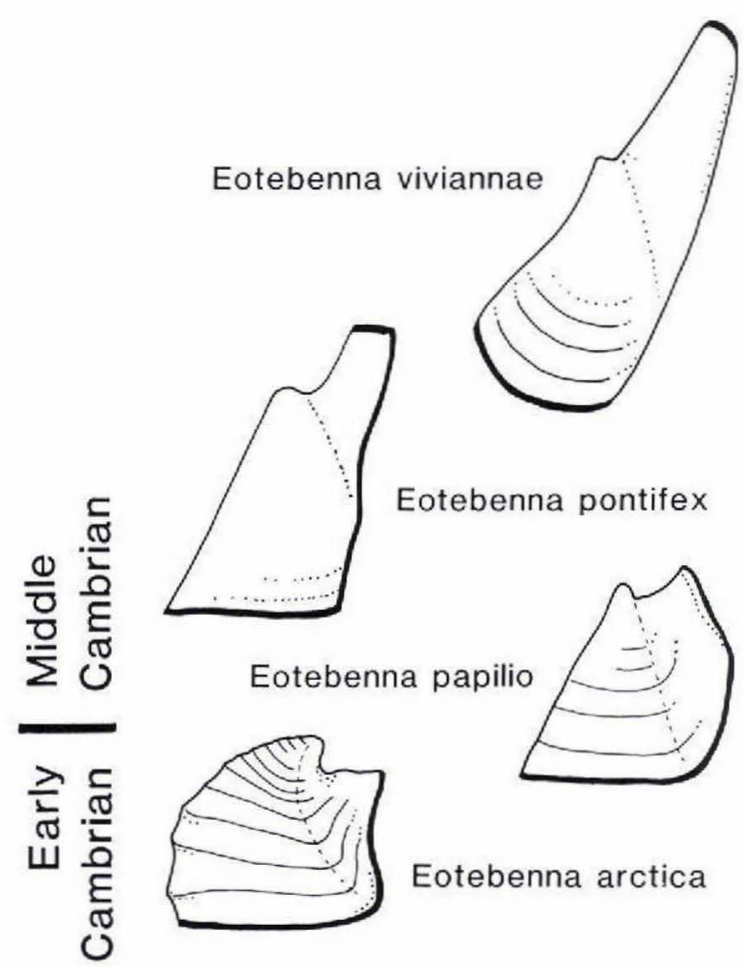

Fig. 30. Morphological series of species of Eotebenna. All species are oriented in lateral view with the anterior to the left; thick black lines indicate the extent of shell openings. The series shows progressive elongation of the shell and increasing separation of the snorkel from the principal aperture, interpreted as a response to greater penetration of the bottom sediment.

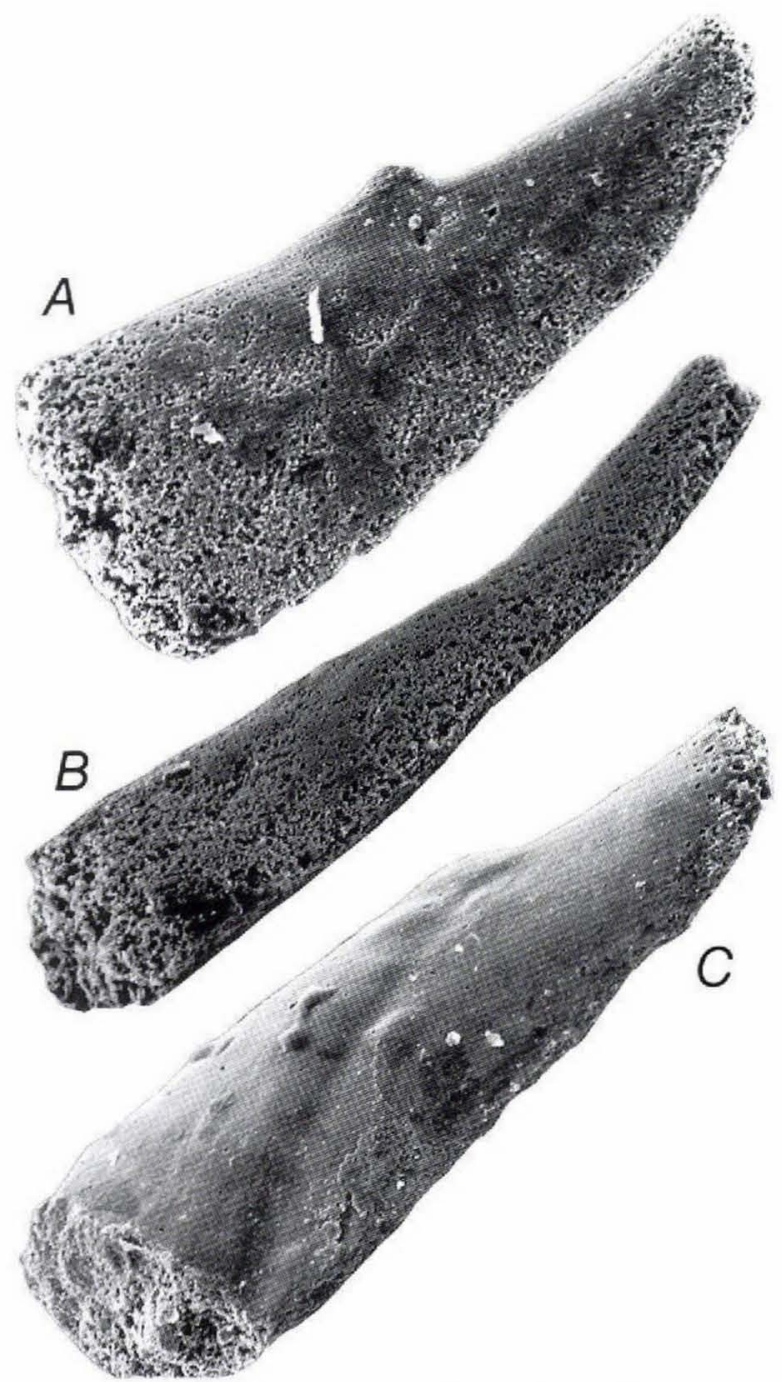

Fig. 31. Eotebenna viviannae Peel, 1991, late Middle Cambrian, phosphatic internal moulds from the Andrarum Limestone, Bornholm, Denmark. A, MGUH 19.565 in lateral view with greatly extended snorkel on the sub-apical surface located to the right, $\times 100 . \mathrm{B}$, as last but rotated to show the line of contact between the lateral areas of the shell, $\times 110$. C, MGUH 19.566 in slightly oblique lateral view with the greatly extended snorkel (right) delimited by a fold producing a groove on the internal mould, crossing from near the apex to the shell aperture (lower left), $\times 100$.

Peel (1991a) recognised a morphological series from Latouchella to the late Early Cambrian Eotebenna arctica Peel, 1989, through the early Middle Cambrian E. papilio Runnegar \& Jell, 1976 and the medial Middle Cambrian E. pontifex to the late Middle Cambrian E. viviannae from Bornholm (Figs 11, 30, 31). The series is characterised by increasing separation of the deepest part of the snorkel-emargination from the aperture, 


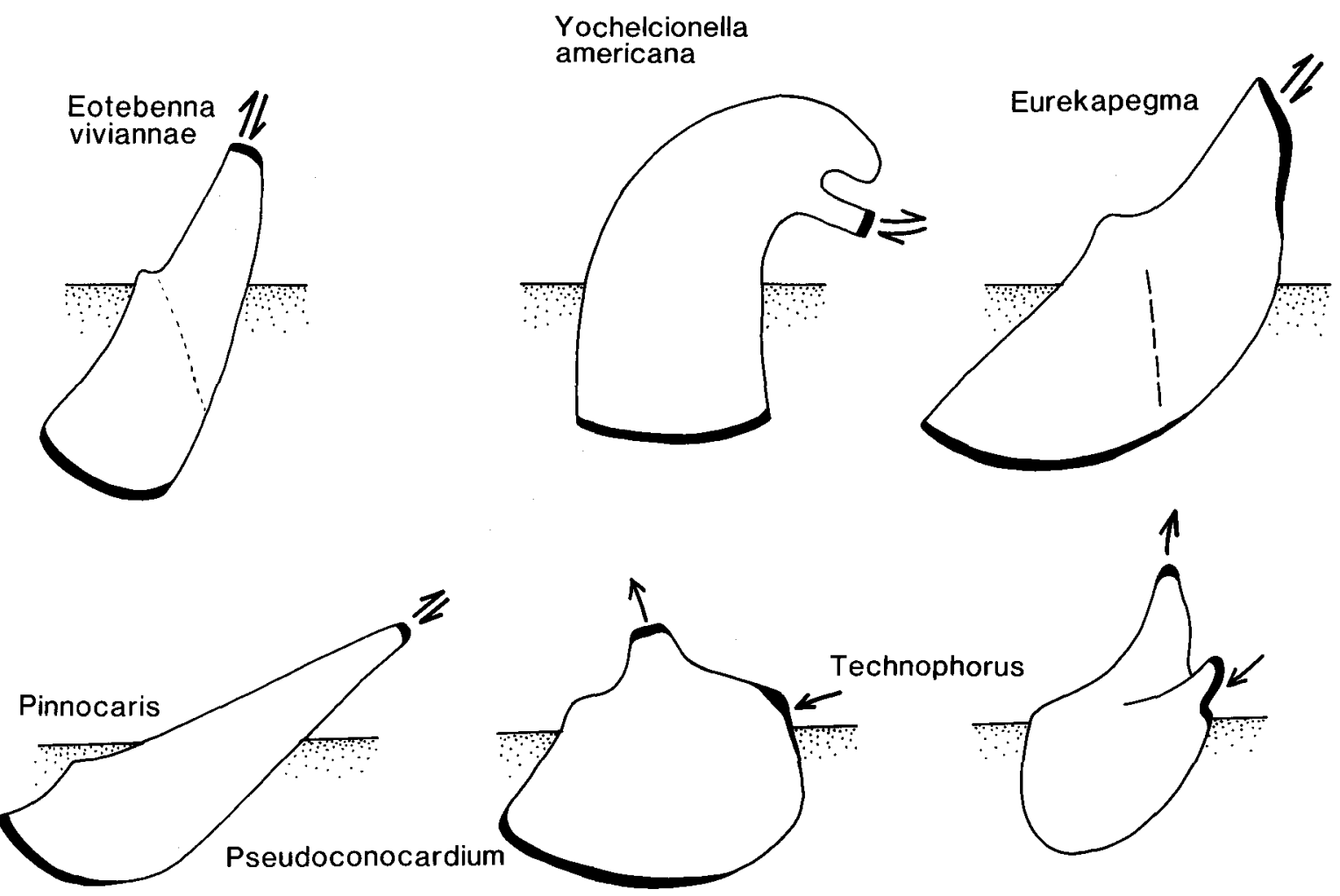

Fig. 32. Reconstructions of the helcionelloids Yochelcionella americana, Eotebenna viviannae and Eurekapegma, and the rostroconchs Pinnocaris, Pseudoconocardium and Technophorus, showing semi-infaunal mode of life. The margins of shell gapes and apertures are indicate by thick black lines, while arrows show inhalant and exhalant water currents. The zygion occuring internally in Eurekapegma is illustrated by a broken line. All shells are oriented with anterior to the left. The large shell gape occupied by the foot (except in Technophorus) is located antero-ventrally within the sediment, indicating that respiration was accomplished via the postero-dorsal shell opening(s). Rostroconchs after Pojeta \& Runnegar (1976).

manifested in elongation of the shell as a result of pronounced allometry, and is interpreted in terms of increasing penetration of the sediment-water interface. However, the anomalous Early Cambrian species from Soviet Central Asia noted above, if an Eotebenna, stresses that this series is morphological and not necessarily phylogenetic.

Early species of Eotebenna probably lived at the sediment-water interface with only slight penetration, but the late Middle Cambrian forms were largely infaunal, with only the shell posterior protruding from the sediment (Fig. 32). This semi-infaunal mode of life probably caused modification of the circulation pattern of water currents within the mantle from that envisaged in older species of the genus and most species of Yochelcionella (cf. Fig. 28B). However, the strongly coiled and laterally compressed Yochelcionella americana may be interpreted in a similar manner to these late Middle Cambrian Eotebenna (Fig. 32). The snorkel in these species may have served both inhalant and exhalant functions, as in scaphopods, many bivalves and rostroconchs, since the antero-ventral aperture was presumably buried within the bottom sediment (Fig. 32). Water supply to the mantle cavity could have been achieved with simultaneous inhalation and exhalation through separate siphons, as in bivalves, but it is perhaps more likely that alternating inhalation and exhalation was employed, as in scaphopods (Yonge \& Thompson, 1976, p. 232).

When restored in this way, Eotebenna viviannae parallels the mode of life inferred for many rostroconchs by Pojeta \& Runnegar (1976) and Pojeta (1987; see Fig. 32 and discussion below) where small posterior and rostral openings above the sediment surface (cf. Runnegar \& Pojeta, 1976; Pojeta, 1987) probably indicate separation of the inhalant and exhalant streams.

\section{The temporary snorkel of Oelandia}

Oelandia was originally described by Westergård (1936) from the Middle Cambrian of Sweden but Peel \& 

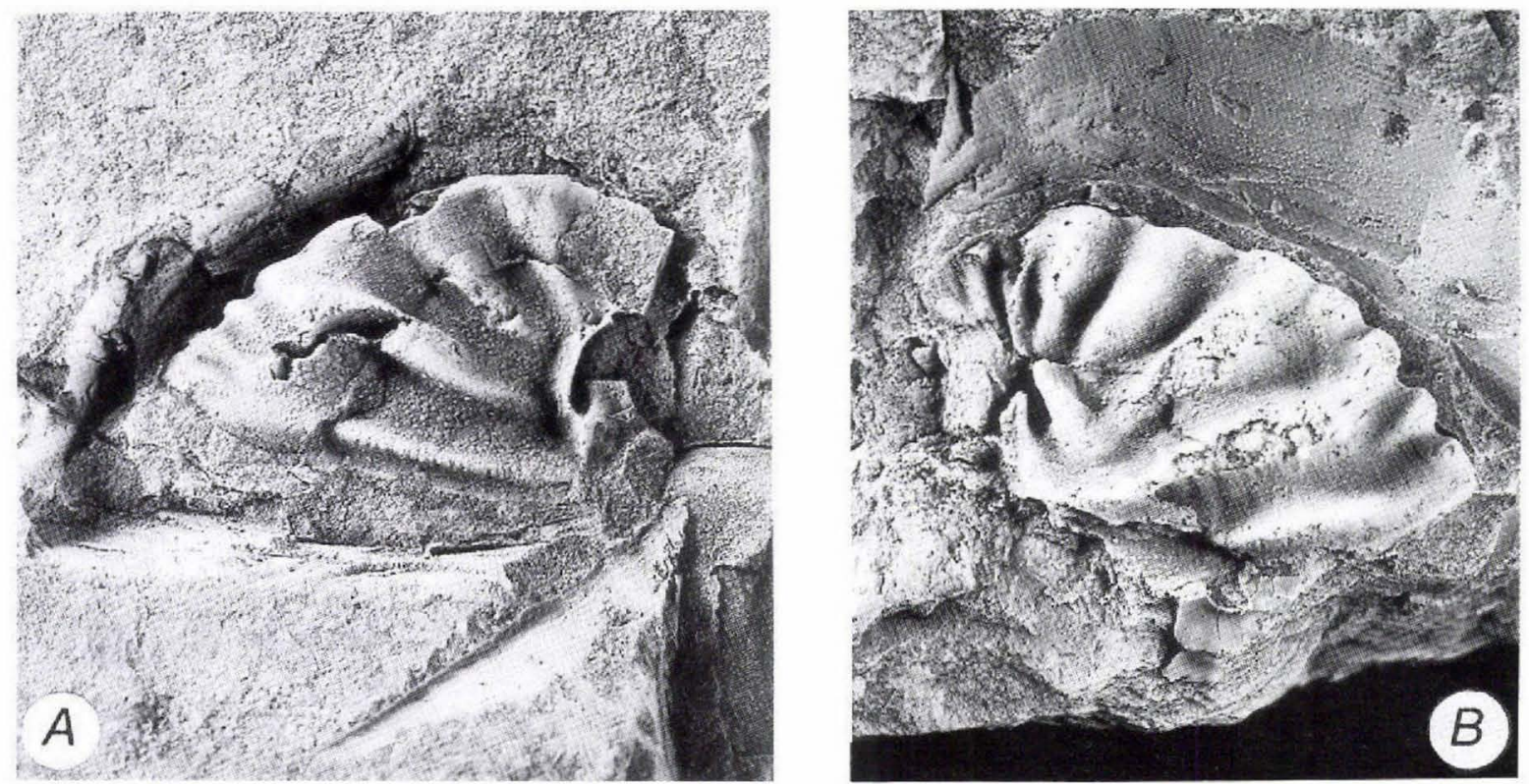

Fig. 33. The helcionelloid Oelandia pauciplicata Westergård, 1936, Middle Cambrian, Öland, Sweden, internal moulds in lateral aspect showing the prominent sediment-filled sub-apical snorkel; the apex of the shell is missing in both specimens. A, LO 5757t, with anterior to the left. The flat-topped snorkel is closed distally (top in figure), probably due to its abandonment with subsequent growth, $\times 6$. B, LO $57578 \mathrm{t}$, with the anterior to the right, $\times 6$.

Yochelson (1987) also noted species from China and North Africa (Geyer, 1986; Yu \& Ning, 1985). An undescribed occurrence has been noted in collections from the Middle Cambrian of Bohemia made by Mr. P. Slehofer and Dr. L. Marek (Czechoslovakian Academy of Sciences, Prague).

Oelandia is unusual among helcionelloids on account of its lack of bilateral symmetry in shell ornamentation. The prominent comarginal plications develop alternately on each lateral area and terminate near the middorsum.

A short tubular structure on the sub-apical wall of new specimens of Oelandia from Sweden (Fig. 33) was compared by Yochelson \& Peel (1987) to the snorkel of Yochelcionella (Fig. 34). A similar structure was illustrated by Geyer (1986, pl. 3, fig. 37) in Oelandia comma (Geyer, 1986) from the Middle Cambrian of North Africa. The tube rises from the plane of the aperture toward the apex and is closed adapically. Peel \& Yochelson (1987) suggested that this closure indicated abandonment of the snorkel with increased growth, its function as the locus of the exhalant current from the mantle cavity possibly being taken over by the median fold in the aperture below the apex. The snorkel in Oelandia may have developed periodically during ontogeny, as do the spines and anterior siphon of some
Fig. 34. Water currents within the mantle cavity of Oelandia and Yochelcionella. Inhalant water streams enter the mantle cavity laterally, and pass over the laterally placed gills prior to exhalation through the posterior snorkel in the sub-apical surface.

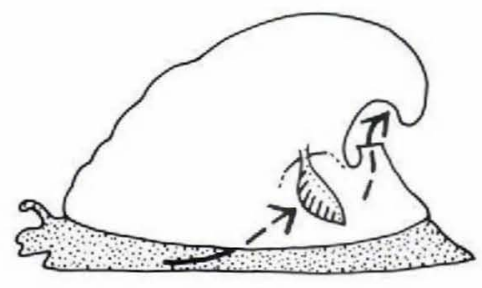

Oelandia

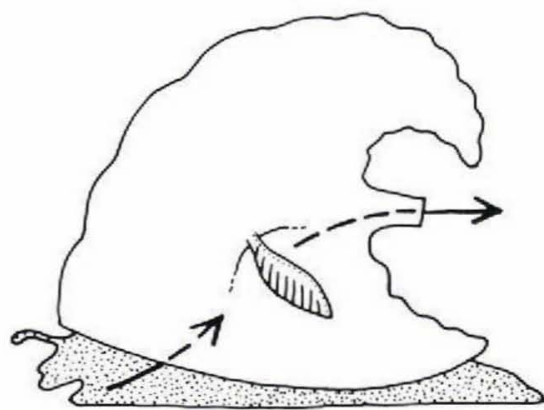

Yochelcionella 
gastropods, but no preserved material shows more than a single tube.

\section{Mode of life of Eurekapegma}

Eurekapegma MacKinnon, 1985, a Middle Cambrian helcionelloid from New Zealand (Figs 32, 35), is characterised by extreme lateral compression, apertural margins convex away from the apex when viewed laterally, and by an internal plate (zygion) connecting opposing lateral areas beneath the apex (MacKinnon, 1985). The zygion might be interpreted as a 'pegma-like' structure reminiscent of that characteristic of rostroconchs, but MacKinnon (1985, fig. 6) considered that it supported internal musculature.

MacKinnon (1985) restored Eurekapegma as semiinfaunal, with the sub-apical surface within the sediment (Fig. 35A). He considered the sub-apical surface to be anterior, in agreement with the model of Runnegar \& Pojeta (1974). However, he proposed that the mantle cavity was located posteriorly, near the supraapical margin, and not concentric around the margins of the shell aperture as suggested by Pojeta \& Runnegar (1976) in Yochelcionella.

Peel (1991a) proposed that the zygion partially delimited the mantle cavity in the sub-apical surface and that Eurekapegma should be restored with the posterior mantle cavity below the sub-apical surface (Fig. 35B). This is the opposite orientation to that suggested by MacKinnon (1985). The shield-like, convex lateral margins in Eurekapegma also suggest a semi-infaunal mode of life, as suggested for some species of Eotebenna (Fig.
32). The closeness of the adapertural termination of the zygion and the almost conjoined apertural margins indicate that water currents probably entered and left the shell on the sub-apical side of the zygion, in similar fashion to the mantle cavity structure proposed for the late Middle Cambrian Eotebenna from Bornholm and many rostroconchs and bivalves in which the larger antero-ventral gape was also buried in the bottom sediment (Fig. 32).

\section{Protowenella, a strongly coiled helcionelloid}

Protowenella is a small (length about 1-2 $\mathrm{mm}$ ) bellerophontiform mollusc which was first described from the Middle Cambrian of Australia by Runnegar \& Jell (1976) and discussed in detail by Berg-Madsen \& Peel (1978) on the basis of material of similar age from Denmark (Fig. 36). Protowenella has been described subsequently from strata of Early and Middle Cambrian age from many parts of the world (e.g. Geyer, 1986; MacKinnon, 1985; Missarzhevsky, 1989). In North Greenland, Peel (1979) reported Protowenella from the uppermost beds of the Henson Gletscher Formation in Løndal, western Peary Land, in strata of Middle Cambrian age.

The small, globose shell of Protowenella is coiled through about one and a half whorls; its shape prompted Runnegar \& Jell (1976) and Runnegar \& Pojeta (1985) to place it as an intermediate form between the helcionelloids and the bellerophontiform molluses in their Order Bellerophontida of the Monoplacophora, together with the globose and strongly

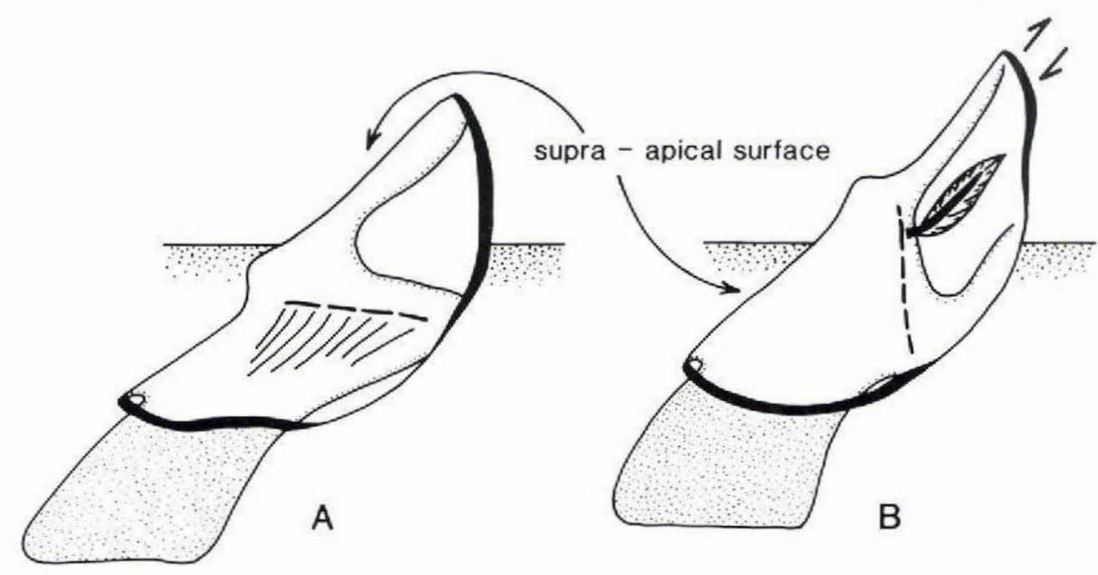

Fig. 35. The mode of life of Eurekapegma, from the Middle Cambrian of New Zealand. A, reconstruction of MacKinnon (1985) in which the exogastric shell is oriented with the sub-apical surface within the sediment. The zygion (dashed line) is considered to provide muscle attachment for the foot (stippled) and the postero-dorsal mantle cavity is located beneath the supra-apical surface. $\mathrm{B}$, interpretation favoured here in which the endogastric Eurekapegma is oriented with the supra-apical surface within the sediment and with the postero-dorsal mantle cavity below the sub-apical surface. Shell gapes are indicated by thick black lines while arrows indicate inhalant and exhalant water currents. 
Fig. 36. Protowenella flemingi Runnegar \& Jell, 1976, the late Middle Cambrian, Kalby Clay, Bornholm, Denmark; MGUH 13.991, internal mould. A, B, lateral views with anterior to right and left, respectively, showing the prominent circumbilical fold, $\times 65$ and $\times 55$. $\mathrm{C}$, as B, showing detail of circumbilical channel, $\times 110$. D, apertural view with posterior at top and anterior at base, showing the prominent circumbilical folds, $\times 85$. E, slightly oblique anterodorsal view showing traces of transverse ornamentation, $\times 65$.
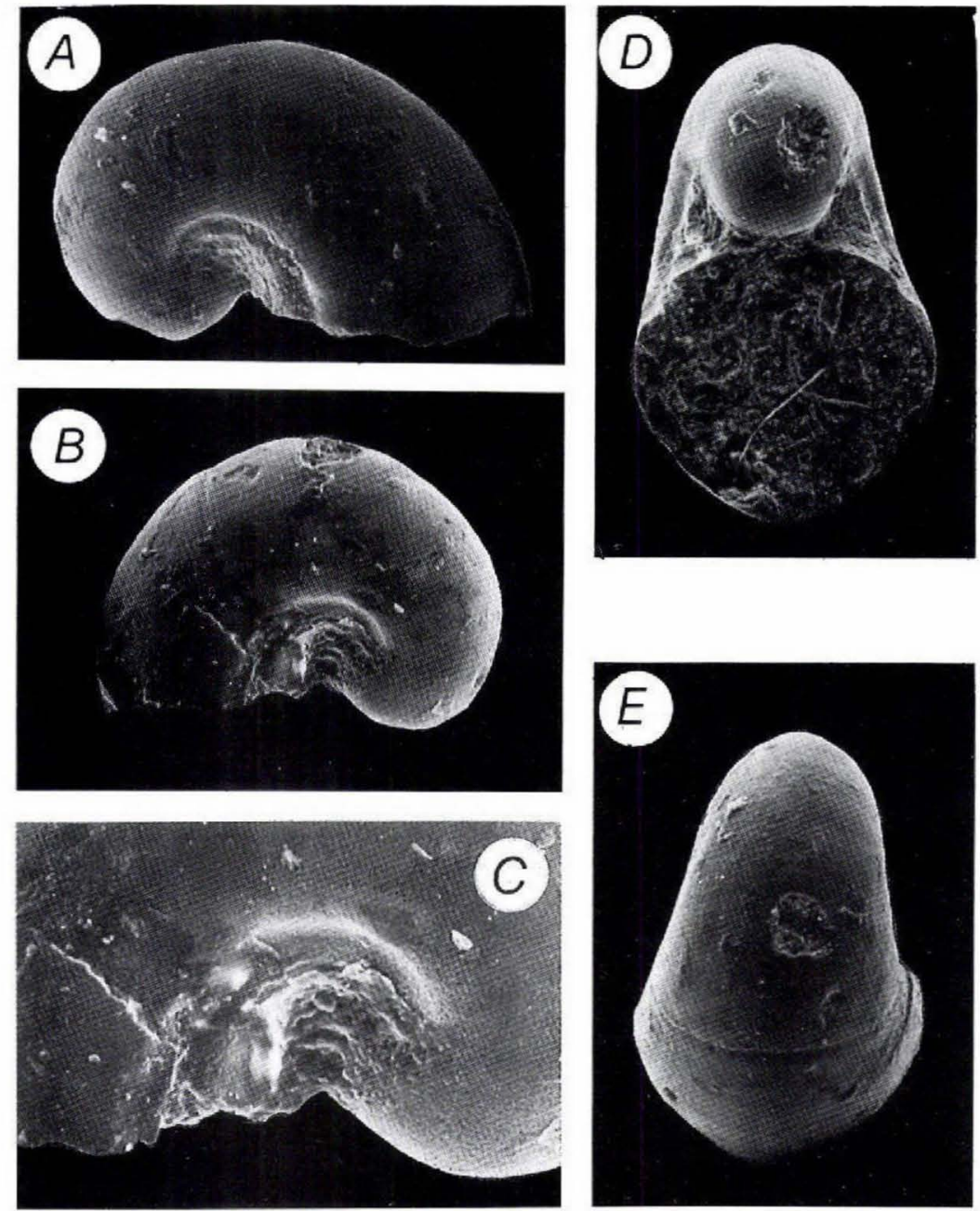

coiled Multifariites, an action strongly criticised by Missarzhevsky (1989).

Berg-Madsen \& Peel (1978) rejected the idea that all bellerophontiform molluscs were untorted monoplacophorans. They considered many to be torted, and therefore gastropods. However, functional interpretation of umbilico-lateral emarginations suggested that Protowenella was untorted and Berg-Madsen \& Peel (1978) consequently assigned it to the Monoplacophora.

Protowenella was assigned to the Class Helcionelloida by Peel (1991a), following abandonment of the Class Monoplacophora. The transfer confirmed the independent conclusion of Missarzhevsky (1989) that Protowenella was related to the Helcionellidae. Missarzhevsky placed the genus in a Family Khairkhaniidae Missarzhevksy, 1989, although his concept of the suprafamilial taxon (to which he gave the name Order Eomonoplacophora) as exogastrically coiled is rejected here (see discussion above).
The lateral emarginations in Protowenella which Berg-Madsen \& Peel (1978) interpreted as marking inhalant water currents are considered comparable to the emarginations noted above in Latouchella, although they are located more deeply within the umbilici on account of the increased inflation of the whorls. Protowenella is thus considered to be endogastric and not exogastric as earlier suggested by Runnegar \& Jell (1976), Berg-Madsen \& Peel (1978) and Missarzhevsky (1989). The functional interpretation by Berg-Madsen \& Peel (1978) of Protowenella as an exogastric tergomyan related to Multifariites remains feasible, but general morphology, the similarity to other helcionelloid taxa and geological age strongly support interpretation of Protowenella as an endogastric helcionelloid.

Danish and Australian specimens assigned to Protowenella can be compared closely to Perssuakiella described from the latest Middle Cambrian Holm Dal Formation (Tavsens Iskappe Group) of central North 

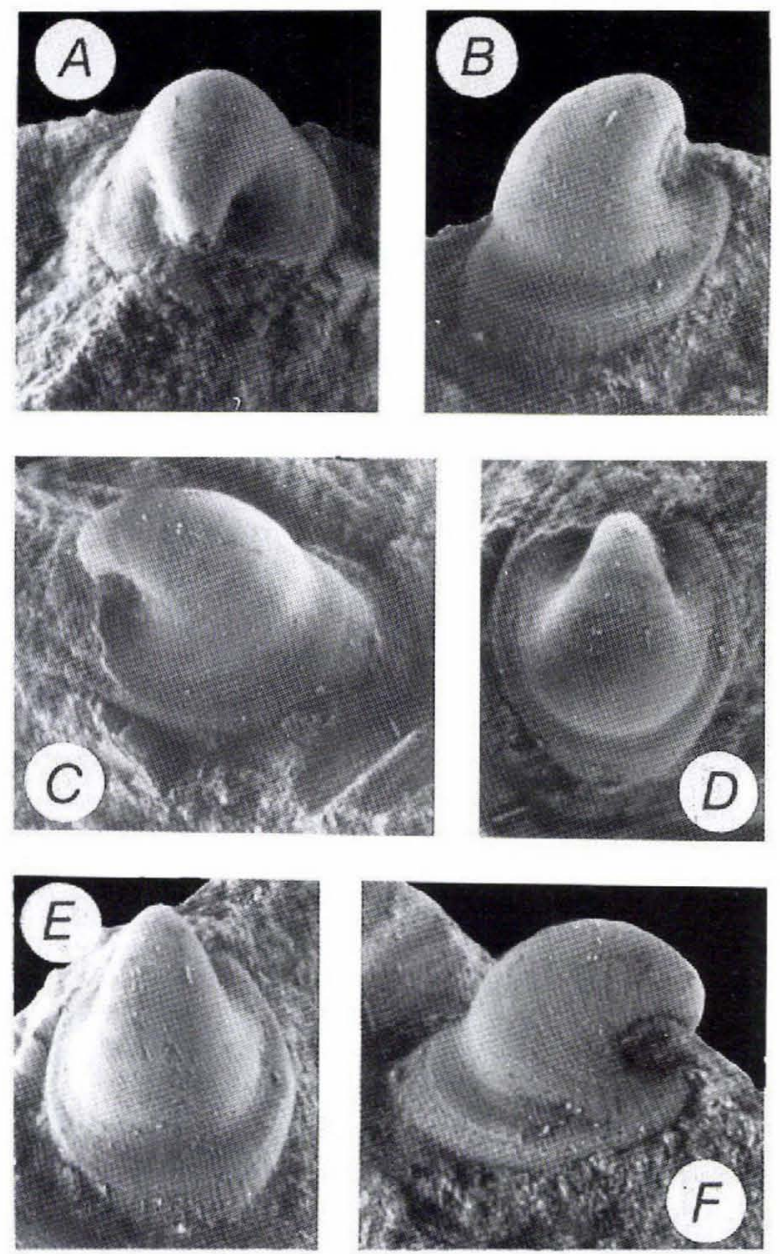

Fig. 37. The helcionelloid Perssuakiella troelseni Peel, 1988, late Middle Cambrian, Holm Dal Formation, Gustav Holm Dal, Peary Land, central North Greenland, MGUH 18.687 from GGU collection 225537, holotype, $\times 15$. A, oblique posterior view. B, C, F, oblique lateral views showing the similarity to Protowenella prior to the expanded aperture. D, dorsal view with posterior uppermost in the photograph. E, oblique dorsal view.

Greenland by Peel (1988b; see Fig. 37). Perssuakiella differs from Protowenella in developing an expanded aperture during the final growth stage, in which feature it resembles the early growth stages of Helcionella. Protowenella-like morphologies can thus be expected to result from preservation of the early growth stages of different helcionelloids.

Tichkaella hamata Geyer, 1986 from the Middle Cambrian of Morocco (Geyer, 1986, pl. 4, fig. 52c) has similar folds on the sub-apical wall to those described in Protowenella and these also may be interpreted as the loci of inhalant currents. Tichkaella resembles Protowenella in terms of its convex dorsal profile but is more loosely coiled.

\section{Helcionelloids and rostroconchs}

Runnegar \& Pojeta (1974) proposed that members of the Class Rostroconchia were derived from helcionelloids and themselves gave rise to the Class Bivalvia (Fig. 5). An anterior apex and coiling toward the rear are a unifying theme within the concept of the Sub-phylum Diasoma. Thus, Runnegar \& Pojeta (1974) homologised helcionelloids with the exogastric tryblidiacean tergomyans, in similar orientation to the majority of bivalves. Rostroconchs, considered to be the only extinct molluscan class by Runnegar \& Pojeta (1974), formed an intermediate link between helcionelloids and bivalves and were assumed to have had a similar original orientation. Pojeta \& Runnegar (1976), Pojeta et al. (1977), Runnegar (1978) and Pojeta $(1985 ; 1987)$ give detailed accounts of rostroconch morphology and evolution.

\section{Rostroconch orientation}

A tubular extension of the shell reminiscent of the helcionelloid snorkel is present in many rostroconchs (Fig. 32). By analogy with scaphopods and bivalves Runnegar \& Pojeta (1974) interpreted this rostrum as lying posteriorly and serving a respiratory function. In contrast, Runnegar \& Pojeta considered that the snorkel of Yochelcionella and Eotebenna performed a similar function, but they located it anteriorly (Fig. 28A, see discussion above).

Similar morphological adaptations to those evident in advanced species of Eotebenna (e.g. Eotebenna viviannae from Bornholm) are present in several rostroconchs and these are also interpreted as having lived partially infaunally (Fig. 32). However, the model of Runnegar 
\& Pojeta (1974) requires that the posterior protrudes from the sediment in rostroconchs while the anterior protrudes in Eotebenna (see Fig. 35 and discussion of Eurekapegma, above).

Runnegar \& Pojeta (1974) noted that many rostroconchs have a large gape which they interpreted as antero-ventral by comparison with living bivalves. A smaller posterior gape often occurs at the tip of the rostrum (Fig. 32). Similar gapes are present in Eotebenna viviannae but the model of Runnegar \& Pojeta requires that the larger gape is postero-ventral and the smaller opening at the tip of the snorkel is anterodorsal; this is the opposite orientation to that which they proposed for rostroconchs.

Following the recognition of the endogastric form in helcionelloids, the large gape and the small snorkel opening of Eotebenna viviannae are now interpreted in the same manner as the corresponding structures in rostroconchs (Fig. 32). Hence, the snorkel of Eotebenna and the rostrum of rostroconchs are both considered to lie at the posterior, while the large gape through which the foot gained contact with the sediment is placed antero-ventrally in both rostroconchs and the helcionelloid genus. As a consequence, similar modes of life can be inferred for Eotebenna viviannae and many rostroconchs on the basis of homologous functional adaptations (Fig. 32).

\section{Pegma-like structures}

Rostroconchs are characterised by the presence of a pegma, a transverse strengthening bar located near the apex. Its appearence in the diasome lineage delimits members of the class from the ancestral helcionelloids (cf. Pojeta, 1985, p. 302; see Fig. 5). By reference to the common supposedly posterior extension of the rostroconch shell, Runnegar \& Pojeta (1974) proposed that the pegma lay anterior to the apex.

A number of helcionelloids preserve structures on the sub-apical surface of the shell interpreted by Runnegar \& Pojeta as 'pegma-like'. Comparison of these structures with the pegma of rostroconchs is a major element in the interpretation of the sub-apical surface of helcionelloids as anterior in the model of Runnegar \& Pojeta (1974). However, the supposed homology between many of these structures and the rostroconch pegma is not convincing or is the subject of debate (Mackinnon, 1985; Peel, 1991a).

MacKinnon (1985) considered the supposed pegma in the Lower Cambrian Heraultipegma, the oldest rostroconch of Runnegar \& Pojeta (Fig. 5), to be produced by phosphatisation around the margin of the sub-apical surface leaving an impression of the shell edge. Kerber
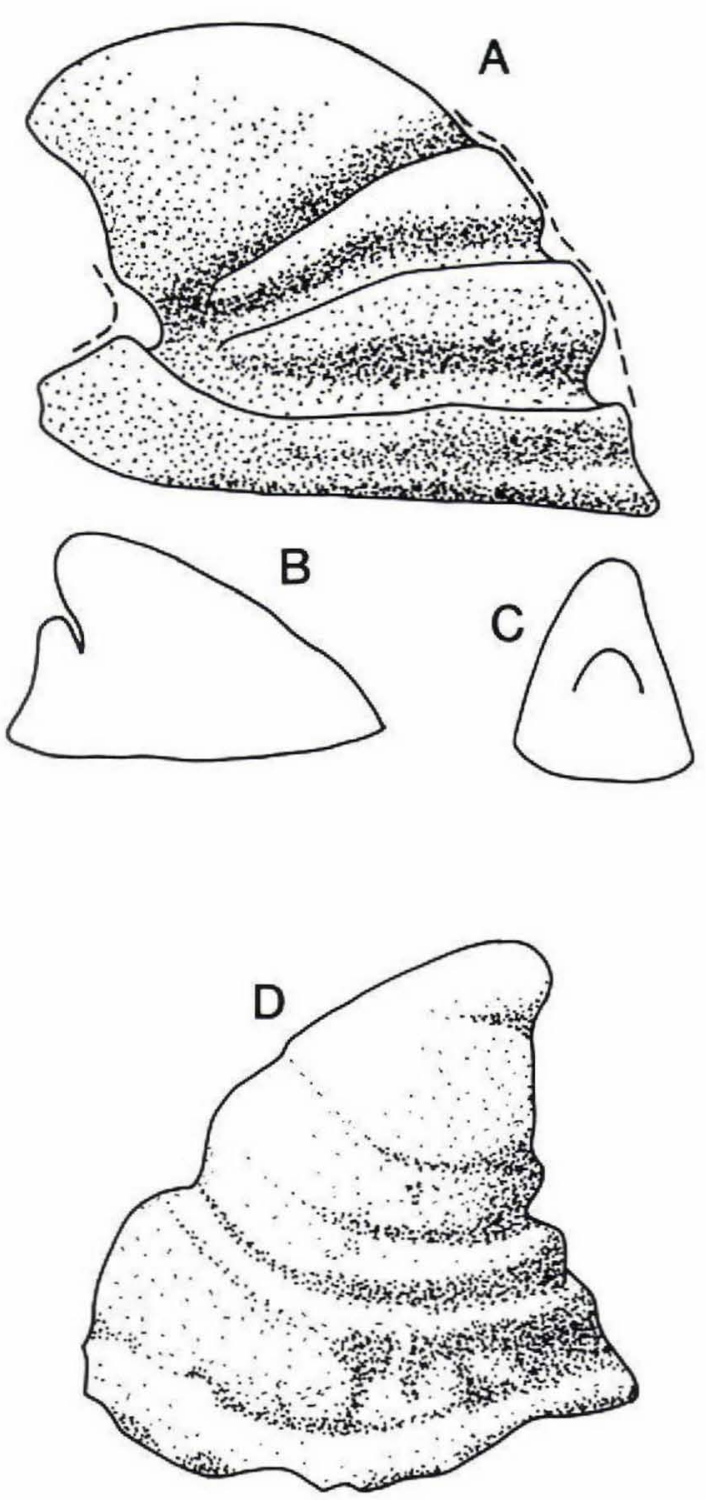

Fig. 38. Pegma-like structures in Mackinnonia, Enigmaconus and Parailsanella. A, lateral view of internal mould of Mackinnonia davidi Runnegar in Bengtson et al., 1990 from the Lower Cambrian of South Australia showing prominent constrictions produced by varix-like thickening on the shell interior. The pegma-like notch below the apex represents part of a continuous comarginal thickening of the shell interior. The original outline of the shell exterior surface is represented by a broken line, $\times 42$ (drawn from Runnegar, 1985, fig. 1A). B, C, Enigmaconus parvus MacKinnon, 1985 from the Middle Cambrian of New Zealand; sketches based on the holotype, a largely exfoliated internal mould, illustrated by MacKinnon (1985) showing the pegma-like notch in lateral and posterior views, $x$ 40. D, Parailsanella acris Zhegallo, 1987 from the Lower Cambrian of the MacKenzie Mountains, Canada; sketch based on the holotype internal mould illustrated by Voronova et al. (1987, pl. 22, fig. 1), × 12 . 
(1988) went further, however, and followed Cobbold (1935) and Müller (1975) in considering Heraultipegma to be an arthropod and not a mollusc. He synonymised Heraultipegma with Watsonella Grabau, 1900, a step supported by Landing (1989), who nevertheless followed Runnegar \& Pojeta (1976) in considering Watsonella to be a rostroconch.

Peel (1991a) noted that sudden changes in growth parameters on the sub-apical surface of helcionelloids can produce deep notches in this surface reminiscent of the rostroconch pegma. Such a notch is visible in the internal mould of a species of Anabarella from the Lower Cambrian of Australia illustrated by Runnegar (1983, fig. 4A) and Runnegar \& Pojeta (1985, fig. 20A; Fig. 11 herein). The species was described as Anabarella argus Runnegar in Bengtson et al. (1990, fig. 164H-N). A similar structure was illustrated by Geyer (1986, pl. 3, figs 35-42) in Oelandia comma from the Middle Cambrian of Spain.

A less deeply incised notch more closely comparable to that in other helcionelliods is present in Anabarella simesi MacKinnon, 1985 from the Middle Cambrian of New Zealand (MacKinnon, 1985, fig. 3a, b). The notch in the Australian species reflects the development of a sub-apical exhalant emargination in this unusually strongly coiled and laterally compressed form. As such, it can be compared with similar apertural folds developed in Eotebenna arctica (Figs 11, 29,30) and Oelandia pauciplicata (Fig. 33).

Runnegar (1985, fig. 1A-E) illustrated an internal mould from the Lower Cambrian of South Australia as Latouchella? $\mathrm{n}$. sp. with pronounced constrictions produced by varix-like thickenings of the shell interior. The specimen was referred to Mackinnonia davidi n. gen. and n. sp. by Runnegar in Bengtson et al. (1990, fig. 159). A deep cleft below the apex resembles the impression of a pegma when the shell is viewed laterally (Fig. 38A). However, the cleft and all the deep channels in the surface of the internal mould are produced by thickenings of the shell interior (the outer surface is smooth) which are continuous around the shell and can not be compared to the rostroconch pegma. Similar specimens occur in the lower member of the Aftenstjernes $\varnothing$ Formation (Brønlund Fjord Group, Early Cambrian) of Peary Land, North Greenland (J. S. Peel, unpublished information). Leptostega? corrugata Runnegar in Bengtson et al. (1990, fig. 160A-G), also from the Lower Cambrian of Australia, shows similar channels on the internal mould probably representing thickenings of the shell interior.

Parailsanella Zhegallo in Voronova et al., 1987, from the Lower Cambrian of the MacKenzie Mountains of Canada, preserves similar structures on the internal mould, interpreted as constrictions on the shell interior (Fig. 38D).

A more convincing pegma-like structure on the subapical surface is present in Enigmaconus MacKinnon, 1985, from the Middle Cambrian of New Zealand (Fig. 38B, C). Enigmaconus, however, has a relatively broad, cone-shaped shell quite different in morphology from the strongly laterally compressed shell of early rostroconchs, making any proposed functional equivalence between the respective transverse bars tenuous. In addition, the pegma-like structure in Enigmaconus is interpreted as posterior, lying on the sub-apical surface, while the pegma of rostroconchs lies anterior to the apex.

Merismoconcha Yu, 1979 preserves transverse furrows on the broadly convex, apparently supra-apical surface of internal moulds which may resemble a pegma-like structure (cf. Kerber, 1988, fig. 19). Kerber (1988) relegated the supposed Class Merismoconchia to a family within the helcionelloids, but the status of this group of problematic Lower Cambrian fossils remains unresolved (cf. Qian \& Bengtson, 1989; Yu, 1989, 1990).

\section{Origin of the cephalopods}

More than a century ago, Schmidt (1888) described a small Lower Cambrian fossil, Volborthella, as the oldest cephalopod. The claims of this and the closely related genus Salterella Billings, 1861 (Fig. 39) to cephalopod ancestry have been restated subsequently by many geologists and biologists. In the context of Greenland geology, Poulsen $(1927,1932,1958)$ described species of Salterella from the Lower Cambrian Wulff River Formation of Inglefield Land, North-West Greenland stating his belief in their cephalopod affinities (cf. Yochelson \& Peel, 1980; Peel \& Yochelson, 1982).

It is now widely accepted that Salterella, Volborthella and related genera are neither cephalopods nor molluscs, but belong to a new phylum to which Yochelson (1977) gave the name Agmata. Fossil agmatans are widespread in Lower Cambrian strata and possess coniform shells containing laminated deposits bearing only a superficial resemblance to the camerate shells of the 

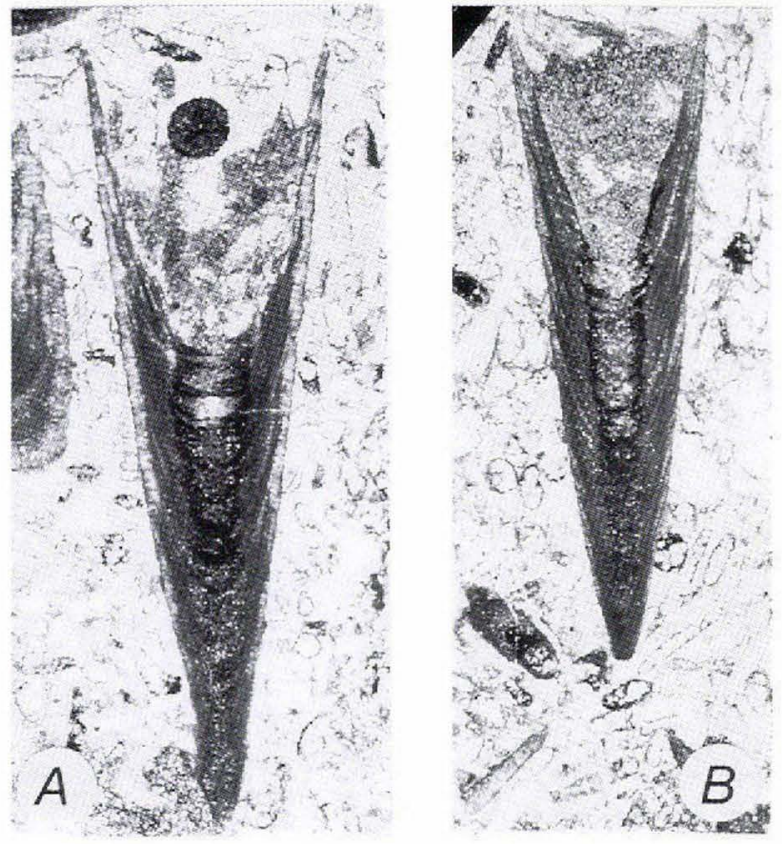

Fig. 39. Salterella maccullochi (Murchison, 1859) from the Lower Cambrian Hyolithus Creek Formation, Kap Weber, North-East Greenland, $\times 10$. Transverse longitudinal sections through the agmatan conch showing the internal lamination and central canal interpreted by some earlier workers as the cephalopod camerae and siphuncle. A, MGUH 15.918; B MGUH 15.920 .

cephalopods (Yochelson 1970, 1981; Fritz \& Yochelson, 1988). A single well documented occurrence of the agamatan genus Ellisell Peel \& Berg-Madsen, 1988, from the Middle Cambrian of Bornholm, Denmark, represents the youngest record of the phylum (Peel \& BergMadsen, 1988).

While agmatans are no longer considered to be closely related to the earliest cephalopods, no consensus has emerged subsequently to explain the origin of the first undoubted cephalopods in the Late Cambrian. The most favoured hypothesis is that cephalopods were derived from tall hypseloconellacean monoplacophorans (here placed within the Order Hypseloconida of the Class Tergomya) with internal septation, by the subsequent acquisition of a siphuncle (Yochelson et al., 1973; see also Webers \& Yochelson, 1989); it can be termed the Knightoconus hypothesis after the hypseloconellacean genus used as a model for the ancestral tergomyan (Fig. 40).

The Knightoconus hypothesis is not without opponents and these mainly base their objections on the need for the siphuncle in the model proposed by Yochelson et al. (1973) to somehow 'penetrate' the se- quence of imperforate septae characteristic of Knightoconus (cf. Chen \& Teichert, 1983; Teichert, 1988; Wade, 1988).

Dzik (1981) suggested that cephalopods were derived from slender, planktonic monoplacophorans which were possibly related to the circothecid hyoliths (Fig. 40). Jell (1978) derived the cephalopods from Yochelcionella, developing the siphuncle from the characteristic snorkel (Fig. 40); this hypothesis was subsequently supported by Pojeta $(1980 ; 1987)$.

Kobayashi (1987) proposed that cephalopods were descended from monoplacophoran molluscs, and he recognised a series from septate Helcionella through Middle Cambrian forms tentatively assigned by Runnegar \& Jell (1976) to the Ordovician genus Pollicina Holzapfel, 1895. Peel (1991a) independently speculated that cephalopods may have been derived from basically endogastric helcionelloids rather than hypseloconellacean tergomyans such as Knightoconus (Fig. 41). He stressed the fundamental difference in coiling between the Tergomya and the Helcionelloida, the whole question of direction of coiling having been overlooked by Kobayashi (1987).

\section{The Knightoconus hypothesis}

Yochelson et al. (1973) derived the first cephalopods from tall monoplacophoran molluses with septate early growth stages, by the subsequent development of a siphuncle. They postulated that a strand of tissue may have retained contact with the earliest portion of the shell as the main body mass migrated anteriorly with growth, and that septa may have formed astride this remnant of tissue which subsequently developed into a siphuncle. Their model was based on the Late Cambrian Knightoconus Yochelson, Flower \& Webers, 1973 in which the apparently endogastric shell bears some morphological similarity to the earliest cephalopod Plectronoceras Ulrich \& Foerste, 1933, described from the Late Cambrian of China (Fig. 40). Knightoconus is a member of the group of supposedly untorted molluscs which Stinchcomb (1986) placed in the Superfamily Hypseloconellacea (Fig. 42); members of this superfamily form the basis of the tergomyan Order Hypseloconida. Knightoconus is distinguished from the nominate genus Hypseloconus Berkey, 1898 mainly on account of its abundant internal septae.

Muscle scars in Hypseloconus were compared by Stinchcomb (1980) with similar muscle scar patterns in tryblidiacean tergomyans such as Pilina (Fig. 1), suggesting that Hypseloconus was indeed endogastric, as deduced by Yochelson et al. (1973). Tergomyans are exogastrically coiled, however, and any phylogenetic 
Fig. 40. Some theories concerning the origin of the earliest cephalopods (Plectronoceras). A, Dzik (1981) suggested that cephalopods were derived from slender, planktonic monoplacophorous molluscs currently classified among the circothecid hyoliths. B, Yochelson et al. (1973) derived cephalopods from endogastric hypseloconellacean Tergomya such as Knightoconus. C, Runnegar \& Jell (1976) considered that tall, slender, secondarily endogastric species of Yochelcionella gave rise to endogastric hypseloconellaceans such as Knightoconus which, following Yochelson et al., were ancestral to the cephalopods. The theory that cephalopods were derived from endogastric helcionelloids is illustrated in Fig. 41. D, Jell (1978) and Pojeta $(1980,1987)$ proposed that tall, slender and secondarily endogastric species of Yochelcionella (such as Y. ostentata) gave rise to cephalopods by conversion of the snorkel into a siphuncle.

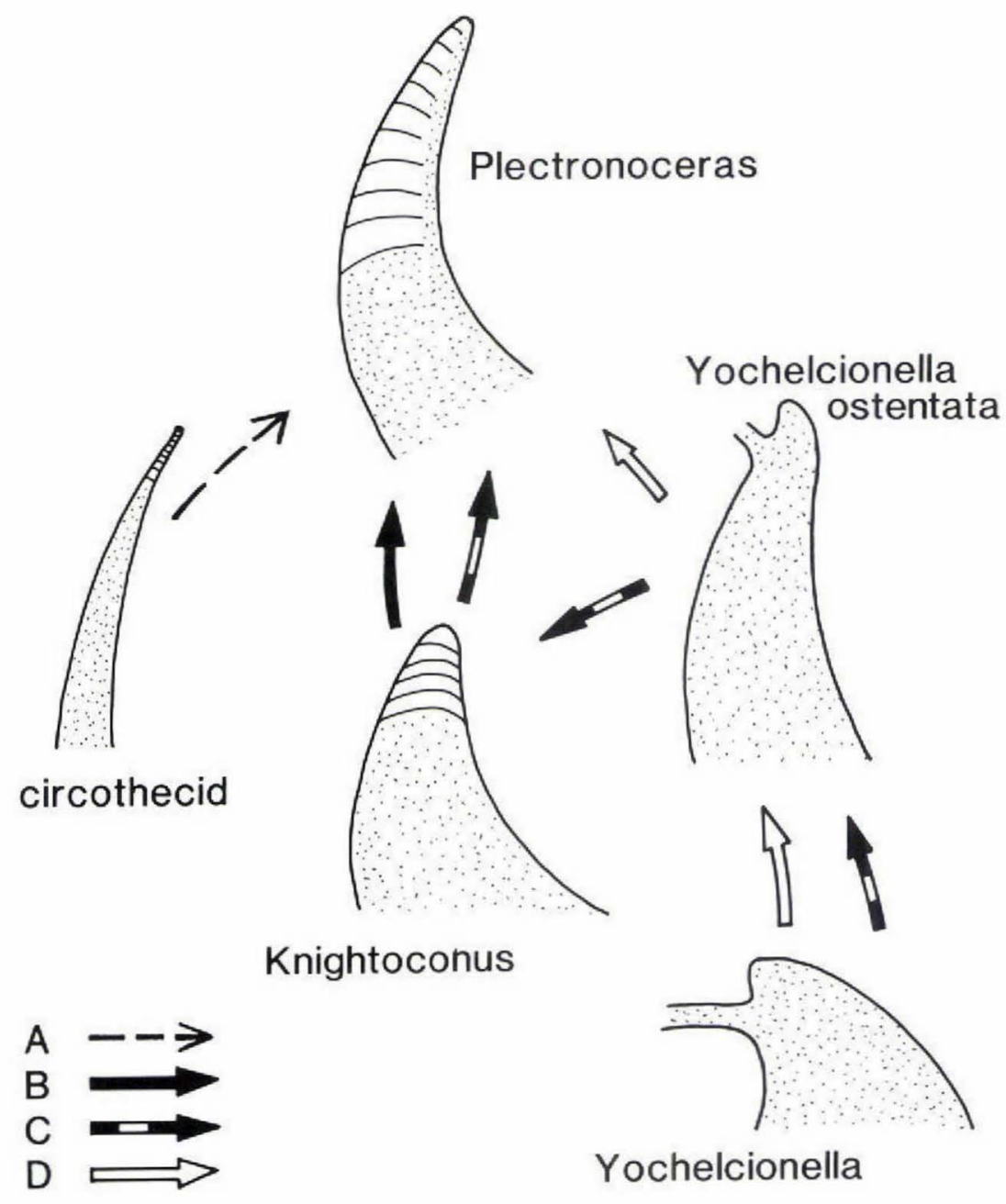

\section{TERGOMYAN}
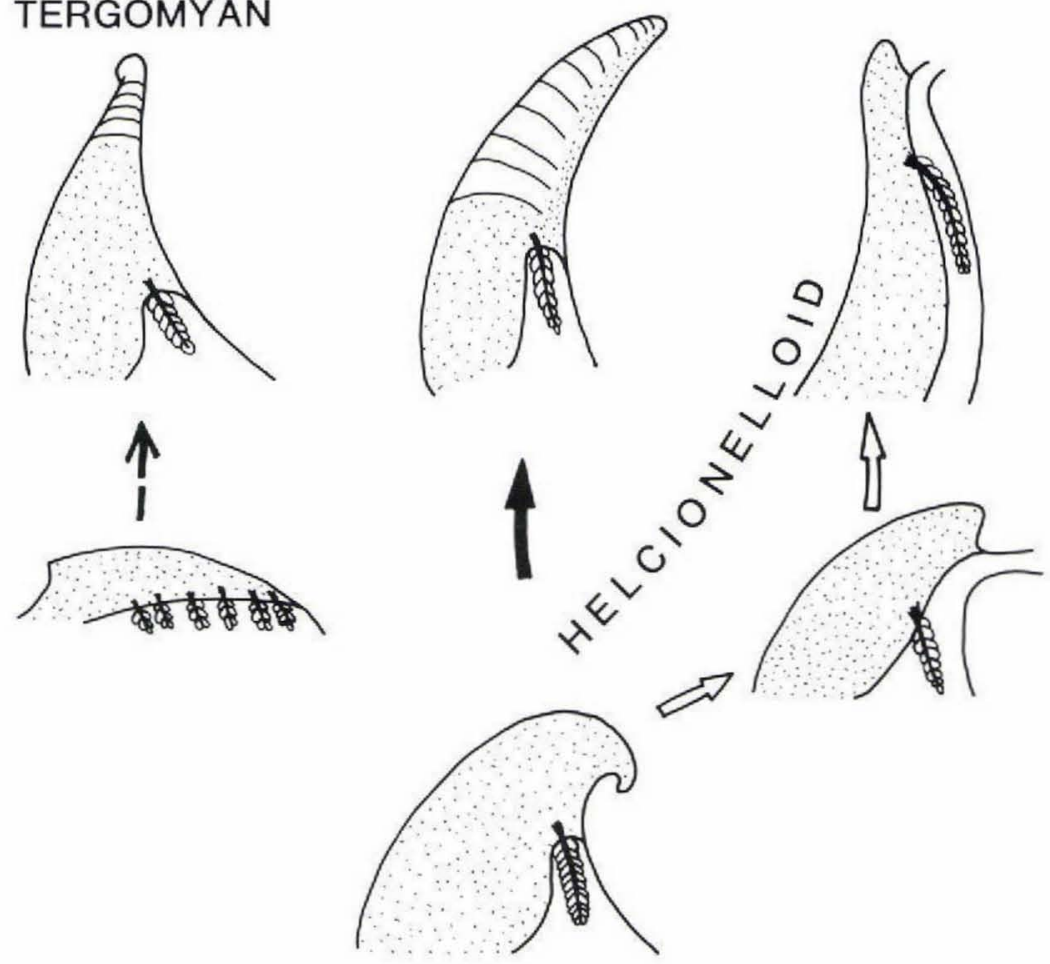

Fig. 41. Derivation of endogastric cephalopods from endogastric helcionelloids compared with the evolution of morphologically similar shell forms within the Tergomya and the helcionelloid Yochelcionella. All specimens are similarly orientated, with anterior to the left and posterior to the right. The mantle cavity and gills are illustrated schematically. 

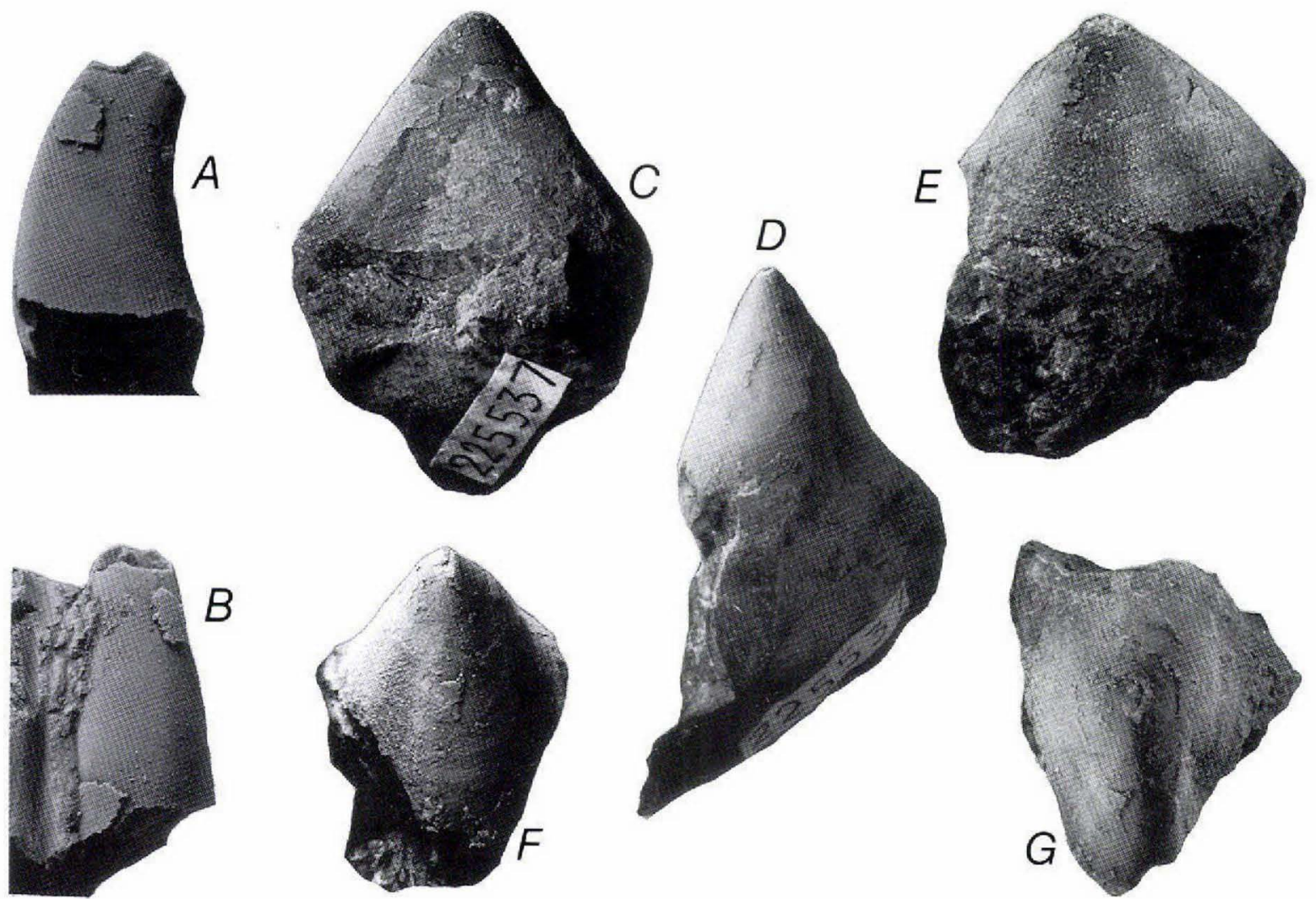

Fig. 42. Hypseloconellid tergomyans from the late Middle Cambrian Holm Dal Formation, Peary Land, central North Greenland. $\mathrm{A}, \mathrm{B}$, internal mould of early growth stages of Hypseloconus sp. in which the apex and the more widely expanded late growth stages are missing, MGUH 18.689 from GGU collection $225529, \times 5$; A, lateral view; B, anterior view. C-G, undetermined hypseloconellacean sp., MGUH 18.691 from GGU collection 225537, × 2; C, lateral view with slightly concave sub-apical surface to right; D, anterior view; E, F, oblique lateral views showing trilobed fold in supra-apical surface; G, apical view with supra-apical surface at bottom.

relationship between them and the apparently endogastric hypseloconellaceans would require a fundamental change in direction of coiling. This discrepancy was resolved by Webers \& Yochelson (1989, fig. 2; see also Webers et al., in press) who described the early growth stages of Knightoconus, clearly demonstrating their exogastric form. Knightoconus changed its direction of coiling during ontogeny to become endogastric in the adult, thus acquiring a pseudo-endogastric shell-form similar to that of Plectronoceras (Fig. 41).

Chen \& Teichert (1983) and Teichert (1988) rejected the theory of Yochelson et al. (1973) that cephalopods were derived from septate Knightoconus stating that it is the siphuncle and not the presence of septa which characterises the Cephalopoda (a statement which Yochelson et al., 1973 did not deny). Septa may be expected in any relatively narrow conical shell in which the animal abandons the narrow early part of the shell and they are developed in a variety of molluscs, including gastropods, helcionelloids and tergomyans. As noted above, the presence of septa in circothecid hyoliths prompted Dzik (1981) to suggest that slender, planktonic monoplacophorans currently placed within this group may have given rise to the Cephalopoda (Fig. 40).

Chen \& Teichert (1983) are undoubtedly correct in their belief concerning the relative importance of the siphuncle and septation in the definition of cephalopods, although the role of septation (or the ability to produce septa) must not be too readily dismissed.

It is the combination of septa and siphuncle which provides the flotation mechanism which was so successfully exploited in cephalopods in the Late Cambrian. More correctly, it is the acquisition of calcareous septa in association with the siphuncle that has allowed recognition of the mechanism of cephalopod flotation in the 
fossil record. A flotation mechanism involving soft tissue alone would leave little trace within the early fossil record (cf. Salvini-Plawen, 1981).

Harper \& Rollins (1982) rejected the model of Yochelson et al. (1973) considering Knightoconus to be a cyclomyan and not an untorted tergomyan (in the sense of Horny, 1965a, b). They believed the Cyclomya to be gastropods; acceptance of the theory of Yochelson et al. (1973) consequently would have required derivation of the untorted cephalopods from the torted Gastropoda and not from some untorted mollusc. This clearly unacceptable derivation of cephalopods from presumed gastropods is avoided here since Knightoconus is interpreted as a specialised tergomyan and not a gastropod; hence it is untorted.

\section{Pseudo-endogastric and pseudo-exogastric}

In reviewing the origin of cephalopods, Runnegar \& Jell (1976, p. 125) speculated that Hypseloconus was able to develop a tall cone because of its endogastric coiling. They considered that endogastric coiling "must have been the most important single character for the production of the Cephalopoda, for it would allow for the development of buoyancy tanks above the body mass". They anticipated the description of the ontogenetic change in the direction of coiling of Knightoconus by Webers \& Yochelson (1989) and Webers et al. (in press), noting how Yochelcionella ostentata from the Middle Cambrian of Australia changed its direction of coiling during ontogeny to acquire a tall shell (Fig. 40). Runnegar \& Jell (1976) suggested that the change in shell curvature resulted from a need to elevate the snorkel and that the curvature was retained in Hypseloconus and Knightoconus after the snorkel was lost.

It is implicit in this argument that Runnegar \& Jell considered Hypseloconus and Knightoconus to be derived from Yochelcionella. However, in the present paper the former two genera are referred to the Class Tergomya while Yochelcionella is assigned to the Class Helcionelloida (cf. Peel, 1991a).

The restoration of Yochelcionella ostentata proposed by Runnegar \& Jell (1976) shows coiling to be originally exogastric and subsequently endogastric; the resultant pseudo-endogastric shell form is thus directly analagous to Hypseloconus and Knightoconus (Fig. 40). Y. ostentata is now interpreted as endogastric in its earlier growth stages, however, with exogastric coiling being developed in its adult stage. Thus, the shell in $Y$. ostentata is pseudo-exogastric and not pseudo-endogastric (Fig. 41), while the hypseloconellacean Knightoconus is pseudo-endogastric.

Following the previously mentioned arguments ex- pressed by Runnegar \& Jell (1976) concerning buoyancy, both pseudo-exogastric and pseudo-endogastric shell forms permit the acquisition of tall and slender cones with a potential for the development of buoyancy above the body mass. This result is also achieved without ontogenetic reversal of coiling direction in straight cones or in shells with a low spiral angle (e.g., $O b$ tusoconus Yu, 1979, see also 'Helcionella' buttsi Resser, 1938; Fig. 11). The development of an orthocline aperture in a straight cone maintains the centre of gravity in a central position above the aperture. Similarly, the development of an opisthocline apertural margin would place the centre of gravity in a similar position in exogastric or endogastric shells with a low spiral angle.

The earliest cephalopods are endogastrically coiled or straight but it is not known if the spectrum of growth forms they represent results from isometric or allometric growth, or from examples of both.

From the point of view of shell coiling, the endogastric shell-form of Plectronoceras, the oldest cephalopod, could have been derived equally from the allometrically coiled, pseudo-endogastric tergomyans such as Knightoconus or from an isometrically coiled helcionelloid which decreased the tightness of coiling of the endogastric shell (Fig. 41), although derivation from a third as yet unrecognised source must not be ruled out. In the first two cases, the deep and narrow, posteriorly located mantle cavity may have contributed to the differentiation of the tissue strand which ultimately developed into the relatively wide siphuncle of the earliest cephalopods. However, as noted by Wade (1988), the siphuncle itself is not developed from the mantle cavity but from the general molluscan cape. The location of the snorkel in Yochelcionella ostentata and morphologically similar species of Eotebenna indicates that the mantle cavity extended almost to the apex; a similar configuration was probably present in some hypseloconellaceans (Fig. 41) and represents a logical trend to obtain the maximum separation of inhalant shell currents from the exhalant stream. The progressive adapertural deposition of septa around the adapical termination of a mantle fold to close off the early growth stages of a slender shell when most of the body mass had migrated adaperturally might thus produce the forerunner to the siphuncle.

\section{The Yochelcionella hypothesis}

While slender species of Yochelcionella such as $Y$. ostentata may offer an important analogy to the 'precephalopod' in terms of shell coiling, as discussed in the previous section, it is unlikely that they were direct 
ancestors of cephalopods as proposed by Jell (1978) and Pojeta (1980, 1987 and Fig. 40 herein).

The reconstruction of $Y$. ostentata favoured by Pojeta \& Runnegar (1976) involves a mantle cavity developed all around the shell aperture with anterior snorkel and laterally disposed gills (Fig. 22A). The development of the snorkel into a siphuncle would place the siphuncle on the opposite side of the shell to that seen in Plectronoceras, the earliest cephalopod, while much of the rest of the mantle cavity would be postero-laterally disposed.

Differentiation of the most adapical part of the elongate mantle cavity into a siphuncle in the reconstruction of $Y$. ostentata favoured here would locate the siphuncle beneath the convex surface (in lateral view) and not beneath the concave surface, as is the case in Plectronoceras (Fig. 41).

\section{The helcionelloid hypothesis}

Kobayashi (1987) derived cephalopods from septate Helcionella by way of tall Middle Cambrian shells tentatively (but incorrectly) referred to Pollicina by Runnegar \& Jell (1976); the same authors also referred grossly similar shells to two species of Stenotheca Hicks, 1872 , indicating that tall shells were developed in several lineages during the Middle Cambrian.

Kobayashi considered Helcionella to be a monoplacophoran. He appears to have accepted the presence of endogastric coiling in Helcionella, following the orientation proposed by Knight et al. (1960) who, however, considered Helcionella to be a gastropod and monoplacophorans to be exogastric. Kobayashi (1987) made no reference to the differentiation of this assumed endogastric coiling from the undoubted exogastric coiling of the Tergomya; neither did he discuss the relationship between Helcionella and the Tergomya.

The new Class Helcionelloida proposed by Peel (1991a) is characterised by endogastric coiling, as distinct from the exogastric coiling of the Class Tergomya. Unaware of Kobayashi's earlier paper, Peel considered the helcionelloids to be possible ancestors of the earliest cephalopods on account of their common endogastric coiling (Fig. 41). In contrast to Kobayashi (1987), Peel (1991a) clearly delimited the relationships of the basic coiling patterns in the major taxa which are fundamental to this hypothesis.

The first cephalopods differentiated into a variety of endogastric and exogastric forms which vary from straight to shallowly curved and tightly coiled (Chen \& Teichert, 1983). However, the dominance of endogastric shells in the earliest fossil record of the class suggests derivation of cephalopods from an endogastric ancestor. Thus, derivation of cephalopods from the endogastric helcionelloids offers a viable alternative to the belief that cephalopods originated from pseudo-endogastric hypseloconidan members of the generally exogastric Tergomya as proposed by Yochelson et al. (1973; cf. Peel, 1991a). As noted above, and as also proposed by Yochelson et al. (1973), progressive adapertural deposition of septa across a tissue strand connecting the body mass to the apex may have eventually resulted in the establishment of a siphuncle.

Helcionelloids are typical of Lower and Middle Cambrian strata while the first cephalopod, Plectronoceras, is of Late Cambrian (late Franconian) age (Chen \& Teichert, 1983). Hypseloconids, favoured by Yochelson et al. (1973) and Webers \& Yochelson (1989) as the stem group for cephalopods, characterise latest Middle Cambrian and younger strata; helcionelloids and hypseloconids are rarely found together, although one such rare occurrence is within the late Middle Cambrian Holm Dal Formation of Peary Land, central North Greenland (Peel, 1988b).

The tall cones of Yochelcionella ostentata and similar species, Knightoconous and other hypseloconids, and the earliest cephalopods represent broadly similar morphological adaptations to possibly analogous environments. Slender species of Yochelcionella are known from Lower and Middle Cambrian strata and rarely exceed $5 \mathrm{~mm}$ in height. The hypseloconids appear in the latest Middle Cambrian (cf. Peel, 1988b) and their massive shells may be ten times larger than Yochelcionella and most helcionelloids. The first Plectronoceras from the Upper Cambrian are less than $1 \mathrm{~cm}$ tall (Yochelson et al., 1973). The variety in shell form both between and within these major taxa suggests that they followed more than one mode of life. 


\section{Diasoma and Cyrtosoma}

The model of molluscan evolution presented by Runnegar \& Pojeta (1974) and subsequently presented in more detailed form by Pojeta \& Runnegar (1976, fig. 14) and Runnegar (1983, fig. 1) refers the univalved and bivalved molluses (the Conchifera of Salvini-Plawen, $1980,1981,1985)$ to the Sub-phyla Diasoma and Cyrtosoma (Fig. 5 and discussion above). Diasomes have univalved (Classes Rostroconchia and Scaphopoda) or bivalved shells (Class Bivalvia) and are characterised by an essentially straight gut. The shell is usually univalved in cyrtosomes and the gut is bent into a U-shape or twisted by torsion. Runnegar \& Pojeta (1974) referred the gastropods, cephalopods and the Class Monoplacophora of their broad usage to the Cyrtosoma.

Approximately equivalent terms to Diasoma and Cyrtosoma employed in neontological circles, but based on other morphological criteria, include Ancyropoda and Loboconcha (for Diasoma) and Rhacopoda and Visceroconcha (for Cyrtosoma; see Lauterbach, 1983a; Salvini-Plawen, 1985; Haszprunar, 1988).

Helcionelloids, interpreted as exogastric monoplacophoran cyrtosomes derived from the tryblidiid lineage, were considered by Runnegar \& Pojeta (1974) to be the ancestors of the Diasoma, indicating that the cyrtosomes are ancestral to the diasomes (Runnegar \& Pojeta, 1985, p. 25). The present re-interpretation of helcionelloids as endogastric inevitably promotes reexamination of this model; the relationship between the Tergomya and the Helcionelloida is discussed in a later section.

\section{The polyphyletic Diasoma}

Peel (1991a) accepted the derivation of the rostronchs from the helcionelloids proposed by Runnegar \& Pojeta (1974). He considered rostroconchs to be originally endogastric, however, in similar fashion to helcionelloids, and not exogastric as proposed by Runnegar \& Pojeta (1974, and later references).

Derivation of rostroconchs from endogastric helcionelloids allows similar structures in both groups to be interpreted as performing the same function, in the same orientation (Fig. 32), while still generally accepting the rostroconch morphological and functional analyses described by Runnegar \& Pojeta (1974) and Pojeta \& Runnegar (1976).

Peel (1991a) accepted the interpretation of the Bivalvia as basically exogastric, as suggested by Runnegar \& Pojeta (1974). He therefore concluded that the Subphylum Diasoma of Runnegar \& Pojeta consists of two distinct, but parallel lineages, with Rostroconchs (and subsequently the scaphopods) evolved from an endogastric helcionelloid ancestor. Hence, Diasoma is not maintained as a monophyletic group since bivalves are presumed to be descendants of an exogastric tergomyan mollusc (cf. Salvini-Plawen, 1985; Stasek, 1972), and not of the endogastric helcionelloids. Haszprunar (1988, p. 403) restated earlier opinions that the bivalve ancestor may have had a more restricted mantle cavity than that of known tryblidiid tergomyans in which the multiple gills are serially arranged. Thus, the peripedial mantle cavity of bivalves with a single pair of gills might be an early molluscan character rather than a secondary simplification from a serial respiratory system. Wingstrand (1985), however, found evidence for serially arranged muscle and gills in early bivalves.

Runnegar \& Pojeta (1985) pointed out that muscle scars are not known in helcionelloids (but see discussion of Scenella sp. undet. below) or the earliest supposed rostroconch of their model (Watsonella crosbyi Grabau, 1900, = Heraultipegma varensalense (Cobbold, 1935), according to Landing, 1989). By analogy to early rostroconchs they suggested that muscles in helcionelloids were concentrated anteriorly and posteriorly of the apex, with a single muscle field in each area crossing the dorsal mid-line from one side of the shell to the other (see Pojeta \& Runnegar, 1976, figs 1, 3). Runnegar \& Pojeta $(1985$, p. 41$)$ further noted that true adductor muscle scars are absent from rostroconchs (with the possible exception of Eopteria Billings, 1865) and that acquisition of these muscles is associated with the "critical event in the origin of the Bivalvia...the appearance of two shell valves with an intervening ligament".

Subsequently, Runnegar \& Pojeta (1985) deduced from the lateral asymmetry of Watsonella (cf. Heraultipegma in Fig. 5), where the supposedly posterior (in their interpretation) supra-apical surface is relatively enlarged, that the posterior adductor muscle scar in the first bivalves should be larger than the anterior adductor scar. In this light, they argue that the large posterior adductor muscle scars of the Early Cambrian bivalves Fordilla Barrande, 1881 and Pojetaia Jell, 1980 are not unexpected.

Following the present interpretation of helcionelloids, the larger muscle attachment area in many rostroconchs (and helcionelloids, if they show a similar musculature but see Scenella sp. undet. below) is anterior and not posterior, as in Pojetaia and Fordilla, thus weakening the similarity proposed by Runnegar \& Pojeta (1985). However, in view of the differences in 
location between the transdorsal muscle scars in rostroconchs (and possibly helcionelloids) and the separate adductor scars of Pojetaia and Fordilla, and associated differences in shell morphology, it is unlikely that the proposed (but here rejected) analogy had any phylogenetic significance. Extant bivalves develop adductor muscle scars of different sizes depending on the relative proportions of the anterior and posterior regions of the shell (cf. Allen, 1985).

As a group of largely infaunal or semi-infaunal molluscs Rostroconchs (Cambrian-Permian) are analagous to the Bivalvia (Cambrian-Recent). However, they were outlived by the bivalves which became increasingly abundant during the post-Palaeozoic. The third class referred to the Diasoma by Runnegar \& Pojeta (1974), the Class Scaphopoda, may represent a specialised remnant of the helcionelloid-rostroconch lineage. Scaphopods (?Middle Ordovician-Recent, cf. Pojeta \& Runnegar, 1979) were probably derived from rostroconchs since helcionelloids are essentially confined to the Early and Middle Cambrian.

\section{Status of the Sub-phylum Cyrtosoma}

The Sub-phylum Cyrtosoma was proposed by Runnegar \& Pojeta (1974) to include the classes Gastropoda and Cephalopoda, together with a broadly defined Class Monoplacophora (Fig. 5). According to Wingstrand (1985), the 'Monoplacophora' forms a stemgroup to the conchiferan molluscs and should be removed from the Cyrtosoma, refuting the opinion of Runnegar \& Pojeta (1985) that the cyrtosomes were the ancestors of the diasomes. The Tryblidiida is a sister group to the other Conchifera in the scheme of SalviniPlawen (1985, fig. 42; see also Lauterbach, 1983a, b, who used the term Neopilinida). However, the remaining Cephalopoda and Gastropoda were considered to form a monophyletic group by Wingstrand, as were the diasomes (Fig. 43).

Wingstrand's concept of the Monoplacophora was essentially identical to the Order Tryblidiida of the Class Tergomya of the present usage, although Runnegar \& Pojeta (1974) employed a much wider definition of the Monoplacophora, including representatives of a number of other molluscan classes. Wingstrand $(1985$, p. 54) noted, however, that "the real troubles come when the pattern of side branches from a tryblidian-like stem is discussed ... No wonder ... that details are missing on this point in most phylogenetical diagrams." His own diagram (Fig. 43) is no exception, although this is readily understood when consideration is given to the host of imperfectly known, but supposedly molluscan lineages
Fig. 43. Evolution of molluscan classes expressed through a diagram simplified from Wingstrand (1985). The Class Tergomya is substituted for Tryblidiida.

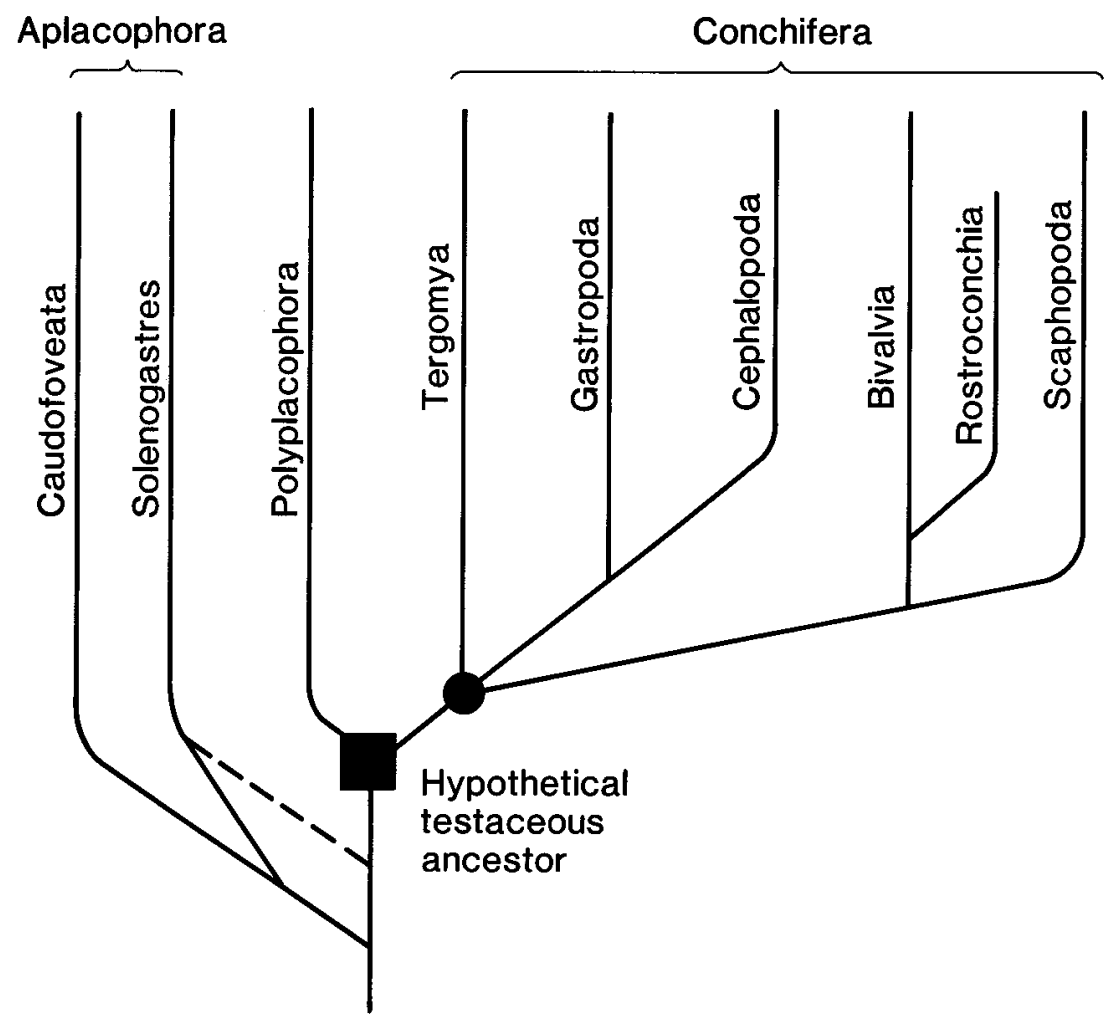




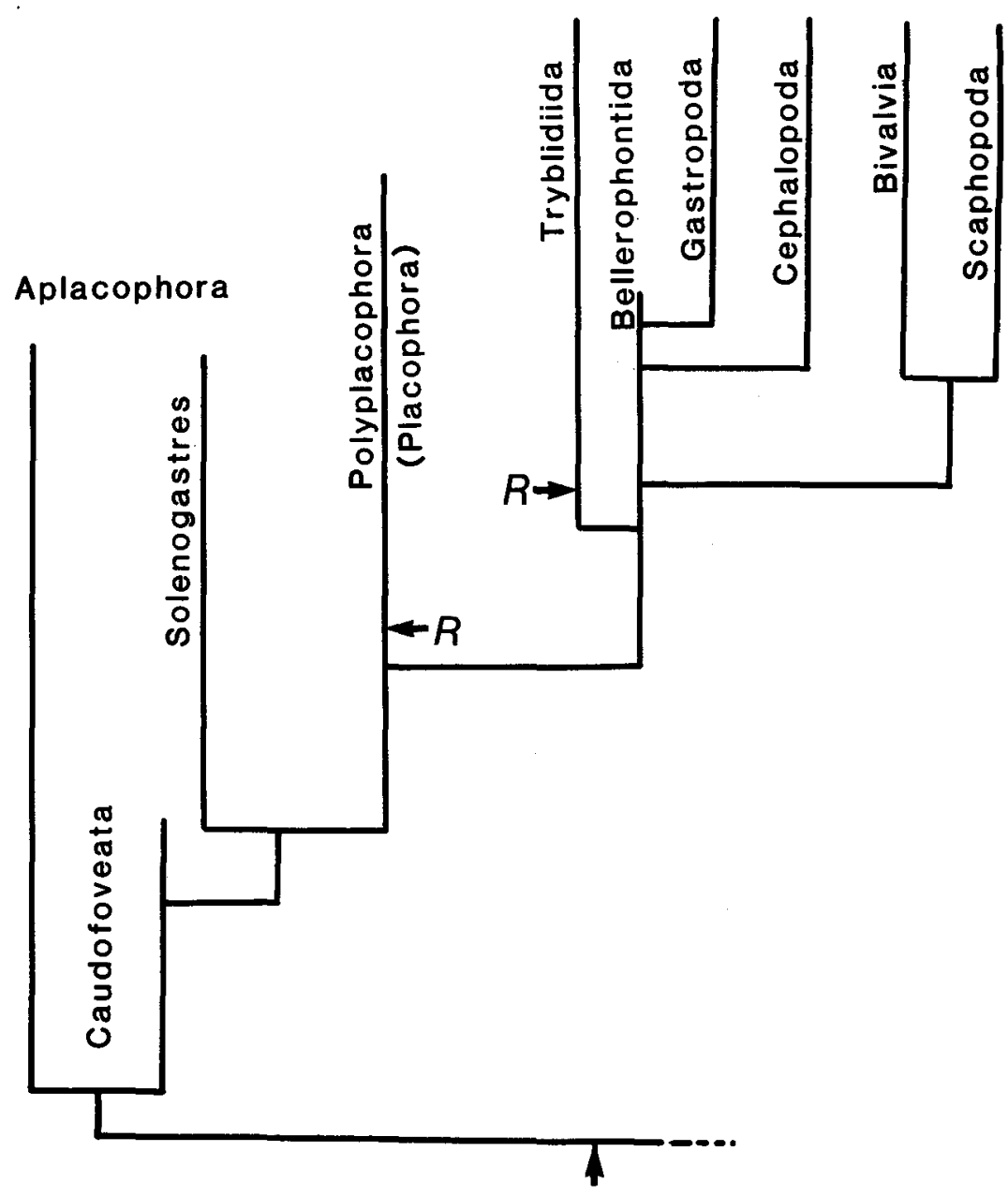

Fig. 44. Molluscan relationships according to Salvini-Plawen (1985, fig. 42). The diagram is modified and simplified, with removal of supposed seven-valved polyplacophorans (see discussion in text). Repetition of gills (R) is considered to have occurred independently in the polyplacophoran and tryblidiid (= tryblidiid tergomyan) branches.

present in Lower and Middle Cambrian strata (cf. Runnegar \& Jell, 1976; Yu, 1987; Missarzhevsky, 1989; Qian \& Bengtson, 1989; Bengtson et al., 1990).

Failure to accept the Monoplacophora of Runnegar \& Pojeta (1974) as a single phylogenetic entity naturally promotes inspection of the integrity of the original Subphylum Cyrtosoma. Any doubts would be reinforced by acceptance of the hypothesis concerning derivation of cephalopods from endogastric helcionelloids, since gastropods were probably derived from exogastric tergomyan-like untorted molluscs resembling the cyrtonellid Tergomya (for an alternative view see Haszprunar, 1988). Derivation of gastropods by torsion in endogastric helcionelloids would produce an exogastric shell and not the familiar endogastric coil of the Gastropoda.
Some morphological similarities between gastropods and cephalopods, such as the posteriorly restricted mantle cavity and the frequently tightly coiled endogastric shell, could in part represent convergence resulting from life within a narrow cone and, as such, are also seen in some helcionelloids. The posterior mantle cavity, however, may also represent an early molluscan feature and its lateral distribution with serial gills in tryblidiid tergomyans would therefore represent a derived condition following the thesis of Salvini-Plawen (1985, fig. 42; see Fig. 44).

In view of the abandonment of Diasoma and the uncertainty surrounding its application, Cyrtosoma is not employed herein in the classification of the Phylum Mollusca. 


\section{Ancestral conchiferans}

A recurring theme in discussions of early molluscan evolution involves the serial distribution of gills and other structures (Salvini-Plawen, 1985; Wingstrand, 1985; Haszprunar, 1988; see also Yochelson 1978, 1979; Runnegar \& Pojeta, 1985). Is the serial repetition of gills present in polyplacophorans and tryblidiid tergomyans a primary character (cf. Wingstrand, 1985), or is it derived from an ancestral condition in which only a few gills are located posteriorly (Salvini-Plawen, 1985)? Complications, inevitably, must be expected since secondary multiplication or reduction of gills and muscle scars may have taken place in response to changes in shell morphologies as molluscs diversified and adapted to their environments. Some measure of the magnitude of these adaptations is indicated by the gill structure of present day gastropod limpets. Fissurellids have a symmetrical pair of bipectinate gills representing the primitive archaeogastropod condition. Acmaeids have only a single gill but may develop secondary gills in the mantle groove around the foot. Both gills are lost in patellids where respiration is accomplished entirely by a series of secondary gills. Limpetoid mesogastropods and neogastropods normally have a single monopectinate gill on the left-hand side of the mantle cavity, while opisthobranch limpets have a single posterior gill. Pulmonate limpets lack gills but the vascularised mantle cavity is thrown into folds resembling gills (Branch, 1985).

The model of Salvini-Plawen $(1980,1981,1985)$ and others involves two episodes of acquisition of serially repeated gills, one with advancement from the aplacophoran level to the polyplacophoran (= Placophora) level, and the second after differentiation of the tryblidiid lineage from the early Conchifera (Fig. 44). Subsequent derivation of the remaining Conchifera maintains a low number of gills with concentration of the mantle cavity in a posterior position (gastropods and cephalopods) or acquisition of a peripedial mantle cavity containing a single pair of gills (bivalves). This model contrasts with that of Wingstrand (1985) and others where the paired muscle scars and gills of tryblidiid tergomyans and polyplacophorans represent a primary molluscan condition (Fig. 43). Thus, according to Runnegar \& Pojeta (1985), helcionelloids are derived from a tergomyan-like ancestor by reduction in the number of gills; the Diasoma, being derived in their model from helcionelloids (Fig. 5), must also be considered to have undergone reduction in the number of gills during their evolutionary history. Interestingly, Wingstrand (1985) recognised clear evidence of serial gills and muscle scars in early bivalves which might appear anomalous if these were derived from helcionelloids with a reduced number of gills as required by Runnegar \& Pojeta (1974).

Fossil tryblidiid Tergomya show some variation in the number of pairs of muscle scars (Knight \& Yochelson, 1960). The fossil record may also provide evidence of secondary reduction of gills within the Tergomya where the morphological series from tryblidiids (with multiple muscle scars and gills, cf. Pilina, Figs 1, 15A) to cyrtonellids (Figs 15D, 18D-F) involves reduction in the number of pairs of muscle scars and (presumably) gills due to the development of a tightly coiled shell. The model of Salvini-Plawen (1985), however, would argue that possession of only a few gills was an original molluscan feature in at least some cyrtonellids; in this model the Bellerophontida were considered to be untorted (i.e. cyrtonellid tergomyans) molluscs ancestral to the gastropods.

A similar trend in muscle and gill reduction is also well known in gastropods. On a cautionary note, however, it should be remembered that muscle scars are known in very few fossil univalve molluscs and critical evidence concerning their relationships is wanting or highly speculative. Similarly, as pointed out by Wingstrand (1985), it is series of muscle scars that are preserved in fossils and not series of gills.

By analogy with cyrtonellid tergomyans and gastropods, laterally compressed and strongly coiled helcionelloids probably had few gills (perhaps only a single pair). This interpretation is possibly strengthened by the small size of helcionelloids (Runnegar \& Pojeta, 1985), although the general small size of Early Cambrian molluscs noted by these authors presumably also applies to the supposedly ancestral tergomyans. The interpreted paucity in the number of gills in helcionelloids is common to the present model, where the mantle cavity is considered to lie posteriorly in an endogastrically coiled shell (cf. Fig. 12B), and to the reconstruction of Runnegar \& Pojeta (1974), where an anterior mantle cavity lies within an exogastric shell (Fig. 12A). The problem is to decide if this condition is an early molluscan feature (cf. the model of Salvini-Plawen, 1985 which did not make reference to helcionelloids and other problematic Cambrian molluscs) or a derived character resulting from reduction in the number of gills after descent from tryblidiid-like Tergomya, as supposed by Runnegar \& Pojeta (1974) and by Wingstrand (1985, although he also did not refer to helcionelloids directly). The issue is central to elucidating the relationship between the Classes Helcionelloida and the Tergomya and focuses attention on the possible occurrence of both 
taxa in the earliest fossil record. The relationship between the two classes can only be elucidated from fossil material by reference to muscle scars and functional morphological assumptions, such as the restricted space available within tall, narrow, shells. As noted above in the discussion of the cyclomyan and tergomyan condition within the Class Tergomya, distribution and variation in muscle scar patterns is also closely related to changes in the coiling parameters of the coiled shell.

\section{Helcionelloid muscle scars}

Undoubted muscle scars are not reported from typical helcionelloids, a feature which prompted Missarzhevsky (1989) to suggest that shell muscles were initially attached into an epithelial layer, with direct attachment to the shell being a later evolutionary development. Missarzhevsky's (1989) idea merits further investigation. Runnegar (1985 and in Bengtson et al., 1990) demonstrated a variety of microscopic structures on phosphatic internal moulds of helcionelloids, many of which replicate the crystal structure of the shell interior. Other structures, e.g. the fine pitting in the internal mould of Latouchella illustrated here as Fig. $24 \mathrm{G}$ (see also MacKinnon, 1985, fig. 1R), are less readily interpreted in this manner. Missarzhevsky's (1989) suggestion served as the basis for his establishment of an Order Eomonoplacophora for the taxa here placed within the Class Helcionelloida but the term is not employed here (see discussion above).

Runnegar \& Pojeta (1985) supported their theory concerning the derivation of helcionelloids from a tryblidiid-like ancestor by reference to Scenella $\mathrm{sp}$. undet. of Rasetti (1974), a Middle Cambrian cap-shaped form from British Columbia in which 6 pairs of muscle scars are preserved (Fig. 45). The muscle scars were held to indicate the anatomy of Neopilina, although Scenella was referred to the Superfamily Helcionellacea in their classification of Cambrian molluscs. As noted elsewhere, the relationship between Rasetti's specimens and the Early Cambrian type species of Scenella is not certain and some authors have even suggested that Scenella is not a mollusc (Yochelson \& Gil-Cid, 1984). Relationship of Scenella sp. undet. to the helcionelloids rather than to the tergomyans is preferred, however, suggesting that helcionelloids showing at least this relatively widely expanded morphology may also have had serially arranged muscle scars and gills (cf. Fig. 22). Supporters of the theory of Salvini-Plawen might argue that these multiple muscle scars in Scenella sp. undet. represent a secondary proliferation or that helcionelloids are derived from the tryblidiid lineage after the development of serial gills and muscle scars characteristic of that group.

Rasetti (1954, plate 12, fig. 5; see Runnegar \& Pojeta, 1985, fig. 11 and Fig. 45 herein) noted that the apex in his specimens of Scenella sp. undet. was excentric and he assumed that it was displaced to the anterior, following Knight (1952). His reconstruction of Scenella is therefore as a tergomyan. Rasetti noted that the pairs of scars were located mainly laterally to, and posterior of, this presumed anterior apex and he related the absence of scars from the sub-apical surface to the presence of the head. The scars are not of uniform size and display slight asymmetry in their distribution (similar asymmetry has been described in Pilina by Peel, 1977a).

Following the current reconstruction of helcionelloids as endogastric molluscs, the apex in Scenella sp. undet. is considered to lie posteriorly. Hence, the absence of scars from the sub-apical region probably does not reflect the position of the head, as suggested by Rasetti (1954), but the location of the mantle cavity.

The uncertainty concerning the systematic position of Scenella sp. undet., its relatively young geological age

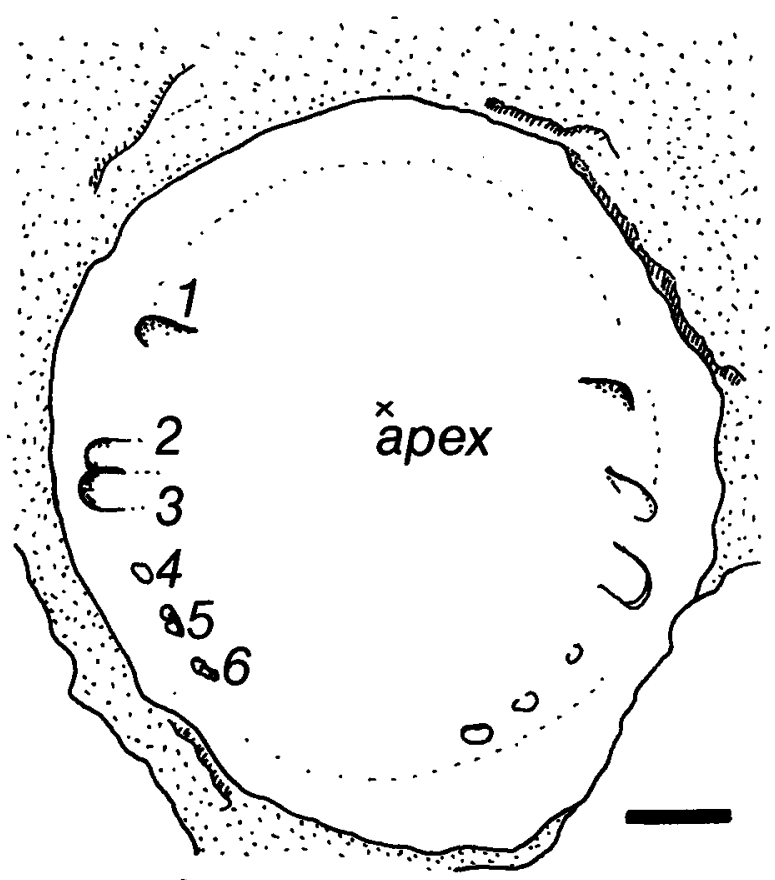

Fig. 45. Scenella sp. undet. of Rasetti (1954, pl. 12, fig. 5). Sketch of USNM 123374, Mt. Whyte Formation, Middle Cambrian, British Columbia, Canada, showing the excentric apex and the paired muscle scars. Rasetti interpreted the apex as anterior, restoring the specimen as a tergomyan, but the apex is here considered to be posterior and Scenella sp. undet. is interpreted as an unusually expanded helcionelloid. Bar is 2 $\mathrm{mm}$. 
(for a helcionelloid), its specialised morphology when compared to other members of the class, and the lack of confirming evidence of musculature from other helcionelloid taxa make Scenella sp. undet. an unreliable indicator of helcionelloid morphology. On the basis of the available evidence, however, it must be tentatively concluded that at least some helcionelloids possessed a serial arrangement of muscle scars and gills, although this need not be analagous with the condition in tryblidiid Tergomya.

\section{The earliest Cambrian molluscs}

Runnegar \& Pojeta (1985) pointed to the occurrence of cap-shaped, limpet-like, shells in the earliest Cambrian of China (cf. Qian \& Bengtson, 1989) which they interpreted as primitive monoplacophorans similar to tryblidiid tergomyans such as Neopilina. These supposedly exogastric limpets were considered to represent a separate calcification event from that which produced the eight-valved polyplacophoran shell (fossils of which are first known from the Late Cambrian) and were not the result of some kind of 'morphological fusion' of a series of ancestral polyplacophoran-like valves into a single shell as otherwise has been postulated (Haszprunar, 1988 , p. 402 , seems to have misinterpreted this statement in claiming that Runnegar \& Pojeta proposed derivation of polyplacophorans from monoplacophoran ancestors). The Meishucun limpets were interpreted by reference to Scenella sp. undet. of Rasetti (1954; see also Runnegar \& Pojeta, 1985, fig. 11) in which the preserved multiple pairs of muscle scars were considered to indicate the anatomy of Neopilina (Fig. 45). As noted above, Runnegar \& Pojeta (1985) derived helcionelloids from tryblidiid tergomyans by secondary reduction of the serially arranged gills, muscle scars and other organs, regarding the helcionelloids as the exogastric probable ancestor of the other shelled molluscs.

Inspection of the Meishucun limpet-like shells figured by Qian \& Bengtson (1989) fails to produce morphologies which can be closely compared to either Scenella sp. undet. of Rasetti or to tryblidiid tergomyans. The most conspicuous elements in the Meishucun molluscan fauna are shells with a scaly or granular surface sculpture, and a variety of coiled shells.

\section{Scaly and granular shells}

This group includes specimens 1-2 $\mathrm{mm}$ in length which are referred to Purella Missarzhevsky, 1974, Xiadongoconus Yu, 1979 and Canopoconus Jiang, 1982. As the shell sculpture implies, these shells are characterised by surface textures suggestive of formation by the coa- lescence of spicules and a similar process has been invoked by Bengtson (1990) to explain the formation of the anterior and posterior shells in articulated halkieriids described from the Lower Cambrian of Greenland by Conway Morris \& Peel (1990; see Peel, 1991b, fig. 2). The Meishucun shells are similar to the halkieriid plates but can not be referred conclusively to a comparable scleritome. The resemblance to tergomyans is superficial and not convincing. In particular, Xiadongoconus preserves an unusual sub-apical fold or extension of the aperture which is more suggestive of a sclerite within a scleritome than of a single univalved molluscan shell.

Other cap-shaped forms from Meishucun, such as Ocruranus Liu, 1979 Eohalobia Jiang, 1982 and Yunnanopleura Yu, 1987, may also represent elements within as yet unrecognised scleritomes, and have little to recommend them as tergomyans or even monoplacophorous molluscs. Some of these, together with co-occurring paracarinachitids, form the basis of the ill-conceived 'Meishucunian polyplacophorans' of Yu (1987, 1989, 1990; Haszprunar, 1988, p. 402), admirably rejected by Qian \& Bengtson (1989; see Peel, 1991b).

\section{Helcionelliform shells}

The second group of Meishucunian coiled shells includes apparent helcionelloids (length up to $2.5 \mathrm{~mm}$ ) tentatively referred to Bemella Missarzhevsky, 1969 and an unusual shell (length up to $2.6 \mathrm{~mm}$ ) called Xianfengella He \& Yang, 1982, with similar planispiral coiling but showing a tendency to develop apertural angulations at the lateral margins of the sub-apical surface in some specimens (cf. Qian \& Bengtson, 1989, fig. 78). In a speculative interpretation, these angulations may represent the locus of inhalant currents to a posterior mantle cavity located sub-apically; this would be in accordance with reconstruction as a helcionelloid since the apertural margin is also excavated to form a possible exhalant sinus beneath the apex. In other respects, however, Xianfengella resembles some members of the Class Stenothecoida but Qian \& Bengtson (1989) were unable to support earlier claims that the genus was bivalved.

The most striking coiled shell from Meishucun is $A r$ chaeospira Yu, 1979 represented by three species (length up to about $2.8 \mathrm{~mm}$ ), although Qian \& Bengtson (1989) point out that species which they tentatively referred to Bemella are closely similar. Archaeospira shows a similar degree of coiling and the same coarse comarginal ornamentation as Latouchella korobkovi (Vostokova, 1962), from the earliest Cambrian of the Soviet Union, but appears to be distinguished from this 
species (and other helcionelloids) by being anisometrically coiled. In standard orientation for a gastropod (which Archaeospira is not), with the aperture facing the viewer and the apex uppermost, Archaeospira is seen to be sinistrally coiled.

In all shell features apart from this anisometric coiling, Archaeospira is typically helcionelloid. The asymmetry can be interpreted, in similar fashion to the asymmetry in pelagiellids (cf. Runnegar \& Pojeta, 1985, fig. 16B; see also Linsley \& Kier, 1984), as slight torsion or reorientation of the shell in an essentially untorted mollusc. Pelagiellids are restored by these authors as exogastrically coiled, with the apex anterior, in accordance with their model for tergomyans and helcionelloids. Archaeospira, interpreted here as an endogastric helcionelloid, would have the apex located posteriorly. Its anisometric coiling allows formation of a sinus immediately adjacent to the coil (cf. Qian \& Bengtson, 1989, fig. 73) and can be viewed as an adaptation to allow the tightly coiled shell to develop an essentially posterior emargination in the otherwise tangential aperture, with minimal interference from the earlier coiled portion of the shell. The relatively great width of the sinus suggests that its purpose was not solely related to improving mantle cavity structure (cf. the broad emargination in some sinuitid gastropods resulting from the development of lateral shield-like extensions to the aperture, Figs 18, 20). As in many pelagiellids, the great rate of whorl expansion produces a shell in which slight asymmetry in coiling has only a small effect on shell balance.

In summary, while helcionelloids are well represented in the earliest Cambrian Meishucun fauna, there are no cap-shaped shells which can be assigned to the Tergomya or considered to be their close ancestors with any degree of confidence. The scaly-ornamented Purella and Canopoconus have bilaterally symmetrical, slightly coiled, relatively high shells showing some similarity to helcionelloids and with a sub-apical emargination which might also support this assignment. It remains to be established, however, whether or not these shells are the univalved shells of molluscs.

Of course, earliest Cambrian molluscs and mollusclike fossils are neither restricted to Meishucun nor to China. Several decades of research in the Soviet Union provided the classic studies of early Cambrian fossils (e.g., Rozanov et al., 1969, translated as Raaben, 1981), most recently synthesised by Missarzhevsky (1989). A greater variety of shells is present than at Meishucun, with primitive bivalves, pelagiellids and coiled gastropod-like forms such as Aldanella Vostokova, 1962. Helcionelloids are conspicuous. As in the Meishucun faunas described by Qian \& Bengtson (1989), convincing tergomyans are absent, but the relationships of many taxa are problematic.
Early Cambrian faunas from South Australia described by Bengtson et al. (1990) include a variety of helcionelloids, pelagiellids and onychochilids. Several internal moulds are assigned to Proplina? spp., a tryblidiid tergomyan genus, but the figured example shows little to commend this identification.

\section{Direction of coiling}

Elucidation of the relationship between tergomyans and helcionelloids requires assessment of the importance assigned to differences in coiling direction in early molluscan evolution. As noted above, the Tergomya show considerable variation in the relationship between shell form and the pattern of muscle scars, with regard to the tergomyan and cyclomyan conditions (Figs 1517), but exogastric coiling is clearly evident in almost all cases, including the pseudo-endogastric Hypseloconida. Within the gastropods, undoubtedly the most diverse molluscan group, endogastric coiling of the shell is also a persistent feature throughout their geological record. Features to suggest that some helcionelloids were not endogastric have not been observed and the form of shell coiling within the group as a whole appears to be uniform. Simple shells without apertural structures obviously yield little direct evidence of orientation, but this comment can be addressed to the shells of tergomyan and gastropod limpets with equal force and to most fossil shells without living relatives. Thus, the endogastrically coiled shell of the helcionelloids is believed to represent a fundamental feature of the class, representing a major difference from the exogastric shell of the Tergomya. Interestingly, the individual conical valves of early polyplacophorans show endogastric coiling, with the apex located posteriorly (cf. Runnegar et al., 1979; Rolfe, 1981).

Interpretations of early mollusc groups such as the Pelagiellida and Onychochilida tend to assume exogastric coiling on account of their development within the conceptual framework that all molluscs of the 'monoplacophoran-grade' were exogastric (cf. Linsley \& Kier, 1984; Runnegar \& Pojeta, 1985). This assumption requires re-assessment in the light of the description of the helcionelloids as endogastric. The tight coiling of the pelagiellids implies only few gills, probably only a single pair, as interpreted in helcionelloids. This strong coiling, their presumed gill structure and early geological appearence promote the idea that pelagiellids may be closely related to the helcionelloids, and therefore endogastric, or represent a parallel development to the Helcionelloida. The circum-apertural structures interpreted as muscle scars by MacKinnon (1985, fig. 10) show some similarity to the folds in the sub-apical surface in Protowenella (Fig. 36). 
The multi-whorled, earliest Cambrian, Aldanella, variously interpreted as a pelagiellid, the first gastropod (or both), a paragastropod or not even a mollusc, may also represent a branch from this early stock (cf. Yochelson, 1978, 1979; Linsley \& Kier, 1984; Runnegar \& Pojeta, 1985; Missarzhevsky, 1989). Ignoring the seductive, but probably fallacious, resemblance to younger gastropods, there is little in the shell form of Aldanella to preclude helcionelloid affinity. Coincidentally, the interpretations of Aldanella as gastropod or helcionelloid share endogastric coiling of the shell, although torsion is assumed to have taken place in the former but not in the latter.

\section{Discussion}

The sparse evidence available from the Middle Cambrian Scenella sp. undet. suggests that at least some helcionelloids possessed a series of muscle scars and gills. Helcionelloids are conspicuous already from the earliest Cambrian and, following arguments inherent in the model of Salvini-Plawen (1985) concerning the secondary acquisition of multiple paired muscle scars in tryblidiid tergomyans, the paired muscle scars in Scenella sp. undet. might be an adaptation to the widely expanded shell form. This would involve at least three episodes of serialisation of muscle scars within early molluscan phylogeny, namely in connection with the origin of the polyplacophorans, the tryblidiid tergomyans and the helcionelloids, unless these groups are related in a manner not foreseen by the model.

A more parsimonious approach would be to follow the thesis of Wingstrand (1985) and others that the serially arranged gills and muscle scars are a fundamental molluscan feature. In this case, secondary reduction in the number of gills becomes a feature of all the other molluscan groups. This theme forms the basis for a graphical representation of the relationships of the mollusc groups discussed in this paper (Fig. 46).

Unfortunately, from the point of view of this representation and Wingstrand's thesis, there is currently scant fossil evidence to support the idea that tryblidiidlike tergomyans with serially arranged muscles and gills were present in the Early Cambrian, as might be expected if they were ancestral to helcionelloids. Helcionelloids are conspicuous in collections of this age and there is a general absence of other cap-shaped shells which might be ancestral to the Tergomya and Helcionelloida. The limitations of the fossil record are legend, of course, but Wingstrand (1985) has rightly pointed out the necessity of rooting phylogenetic discussions in fossil material, rather than solely in the extract of the more than 500000000 years of molluscan evolution represented by the anatomy of the living fauna.

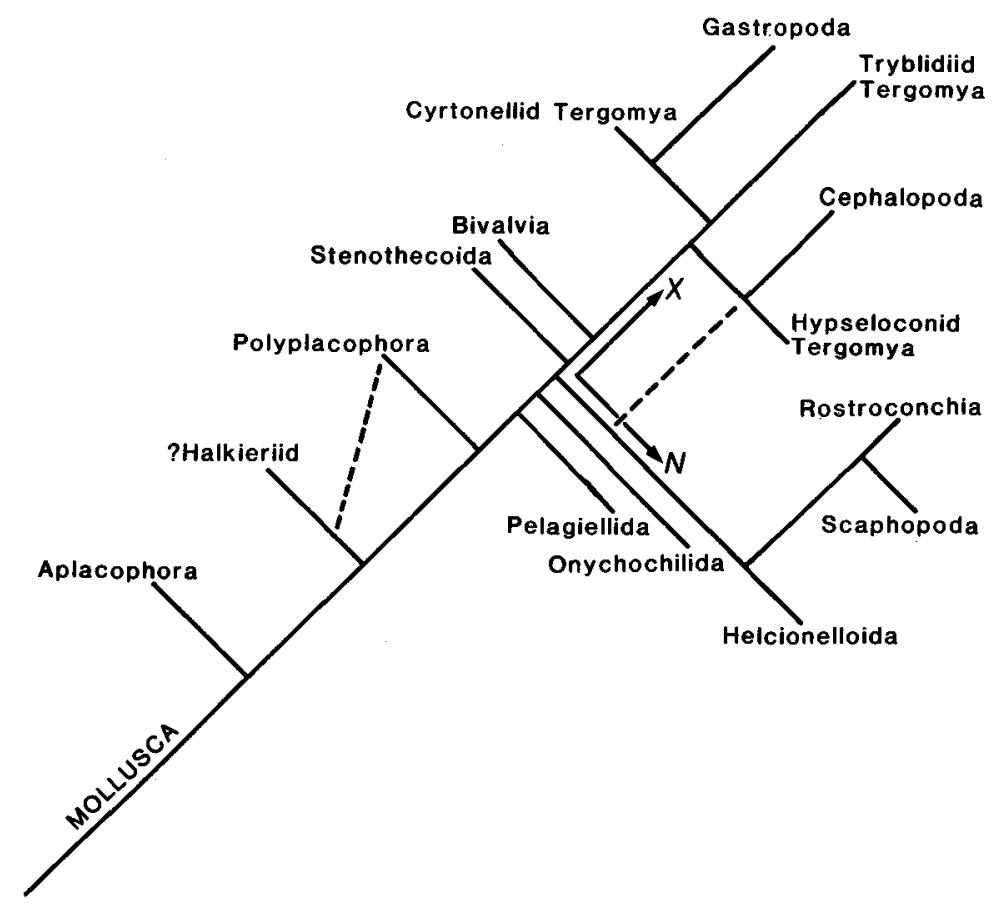

Fig. 46. A graphical representation of the relationship of mollusc groups. The central theme is that molluses show some degree of original serial distribution of muscles, gills and other organs which is often subsequently lost or reduced. This serialisation, however, may have not been as fully expressed as in tryblidiid Tergomya and Polyplacophora. Halkieriids are interpreted as possible early molluscs, representing a parallel (or ancestral?) lineage to the Polyplacophora. Helcionelloida form an early endogastric branch (N) from which Rostroconchia, Scaphopoda and possibly Cephalopoda were derived. Pelagiellida and Onychochilida parallel the helcionelloid branch or may be derived from the helcionelloid lineage if interpreted as endogastric. Stenothecoida and Bivalvia represent unrelated adaptations to the bivalve form, paralleling the trend seen within the endogastric Rostroconchia; the relationship of the Stenothecoida to other molluscan groups is unclear, as is its presumed originally exogastric coiling (X). 
Helcionelloids dominate the Early and Middle Cambrian with tergomyans first becoming conspicuous near the Middle Cambrian - Late Cambrian boundary, with the incoming of the Hypseloconida. Thus, the fossil record arguably promotes the idea that helcionelloids are ancestral to the Tergomya, or that they represent an early offshoot from the ancestral line leading to the Tergomya. Pelagiellids and onychochilids similarly may represent branches fron this line. Supporters of the Salvini-Plawen model can cite this as evidence for the secondary acquisition of serial muscle scars and gills in tergomyans if it is accepted that only few gills are originally present in early helcionelloids (although see discussion of Scenella sp. undet. above) and pelagiellids; it is not unlikely that tryblidiid tergomyans, like gastropod limpets, modified their internal anatomy, including muscles and gills, in response to the limpetoid shell form. However, the change may be an increase in the degree of serialisation rather than the development of serialisation from an ancestor without serially arranged gills and muscle scars.

Applying the same geological measure, polyplacophorans should also be a relatively late development in molluscan evolution, a point of view lacking support in both the models of Salvini-Plawen (1985) and Wingstrand (1985), although favoured by Yochelson (1978, 1979). The recent description of the articulated halkieriid scleritome (Conway Morris \& Peel, 1990; Peel, 1991b) provides a potential solution to this quandary if a role can be allocated to halkieriids in early molluscan evolution (Fig. 46). However, some of the problems associated with the lack of agreement between the various models and the fossil record can be resolved if formation of the dorsal shell by fusion of spicules occurred later in the tergomyan lineage than in the helcionelloid branch, in the same way that the Polyplacophora and possibly the halkieriids (cf. Bengtson, 1990; Peel, 1991b) may also represent separate calcification events (cf. Runnegar \& Pojeta, 1985). This would imply that shell development in the Conchifera, widely considered to be a unifying character, took place on more than one occasion.

Early molluscan evolution, viewed in a palaeontological context, is more complex than the models expressed by Wingstrand (1985) and Salvini-Plawen (1985), although it must be stressed that their respective points of view lie in studies of molluscan groups which have survived to the present. Almost 30 years ago, Yochelson (1963; see also 1978, 1979) expressed the point of view that a radiation of molluscs in the Early Cambrian was eclipsed by more advanced forms such as the cephalopods and bivalves evolving near the Cambrian-Ordo- vician boundary. Placement of the tryblidiid tergomyans (as Monoplacophora) within this second group clearly indicated that these were not considered to be the basic molluscan stock. It is this apparently late appearence (or calcification?) of both tryblidiid tergomyans and polyplacophorans (and also cephalopods and undisputed gastropods) in the fossil record, in this second burst of molluscan evolution, that currently causes difficulties for the models of Wingstrand (1985) and Salvini-Plawen (1985). The passing decades since Yochelson's paper in 1963 have seen a great increase in our knowledge of especially Early Cambrian molluscs and attempts such as those of Runnegar \& Pojeta (1974) and Yu $(1989,1990)$ to extend familiar molluscan classes, such as the gastropods, bivalves, tergomyans and polyplacophorans, back through the Cambrian to these early times. So far, these efforts have met with varying degrees of success in an ancient world where the 'comfortable' molluscan morphologies of present seas comprise a minority in a spectrum of unfamiliar shapes and forms. Most of the early experiments, such as the helcionelloids discussed here, the pelagiellids and the stenothecidans, were short lived, scarcely surviving the Cambrian, although other problematic lineages such as the Rostroconchia, Onychochilida and the Hyolitha survived through most or all of the Palaeozoic (the Hyolitha may or may not be molluscs, see discussion by Runnegar et al., 1975; Marek \& Yochelson, 1976; Sysoyev, 1984). As is often the case (cf. Bengtson, 1991; Ramsköld \& Hou, 1991), new information from early Cambrian fossil groups creates initial confusion, generates opposing standpoints and requires digestion before it can be assimilated ultimately into a larger vista of evolving life. The study of early molluscs is no exception, but this is both the enigma and the fascination of the Cambrian.

Acknowledgements. Peter Jell (Queensland Museum) generously donated specimens of Latouchella merino Runnegar \& Jell, 1976 for study. Radvan Horny (National Museum of Prague) kindly made manuscripts in press available for consultation, translated sections of Missarzhevsky (1989) into English and supplied the photographs of Sinuitopsis in Fig. 18. An earlier version of the manuscript benefitted from reviews by Doug Erwin and Ellis Yochelson (U.S. National Museum of Natural History, Washington D.C.).

Institutions are denoted by the following abbreviations cited in the text: GGU, Geological Survey of Greenland, Copenhagen, Denmark; GSC, Geological Survey of Canada, Ottawa, Canada; LO, Palaeontological type collections of the University of Lund, Sweden. MMH and MGUH, Geological Museum, University of Copenhagen, Denmark; NMW, National Museum of Wales, Cardiff, Wales, U.K.; OUM, Oxford University Museum, U.K.; P2 L, Department of Palaeontology, 
National Museum of Prague, Czechoslovakia; SM, Sedgwick Museum, Cambridge, U.K.; YPM, Yale Peabody Museum, New Haven, Conn., U.S.A.; USNM, U.S. National Museum of Natural History, Washington D.C., U.S.A.; their staffs are acknowledged for the loan of specimens in their care.

Bente Thomas, Bodil Sikker Hansen, Jens Nymose and Jakob Lautrup gave draughting and photographic support. Scanning facilities were provided by the Laboratory for electron microscopy, University of Copenhagen.

\section{References}

Aksarina, N. A. 1968: [New data on the geology and guide fossils of western Siberia] 3, 77-86. Tomsk: Univ. Tomsk, [in Russian].

Allen, J. A. 1985: The recent Bivalvia: their form and function. In Trueman, E. R. \& Clarke, M. R. (ed.) The Mollusca 10. Evolution, 337-403. Orlando: Academic Press.

Bengtson, S. 1990: The solution to a jigsaw puzzle. Nature 345, 765-766.

Bengtson, S. 1991: Oddballs from the Cambrian start to get even. Nature, 351, 184-185.

Bengtson, S., Conway Morris, S., Cooper, B. J., Jell, P. A. \& Runnegar, B. N. 1990: Early Cambrian fossils from South Australia. Mem. Australas. Assoc. Palaeontol. 9, 364 pp.

Berg-Madsen, V. 1987: Tuarangia from Bornholm (Denmark) and similarities in Baltoscandian and Australasian late Middle Cambrian faunas. Alcheringa 11, 245-259.

Berg-Madsen, V., \& Peel, J. S. 1978: Middle Cambrian monoplacophorans from Bornholm and Australia, and the systematic position of the bellerophontiform molluscs. Lethaia 11, 113-125.

Berg-Madsen, V., \& Peel, J. S. 1987: Yochelcionella (Mollusca) from the late Middle Cambrian of Bornholm, Denmark. Bull. Geol. Soc. Denmark 36, 259-261.

Branch, G. M. 1985: Limpets: evolution and adaptation. In Trueman, E. R. \& Clarke, M. R. (ed.) The Mollusca 10. Evolution, 187-220. Orlando: Academic Press.

Brasier, M. D. 1975: An outline history of seagrass communities. Palaeontology 18, 681-702.

Chen Jun-Yuan \& Teichert, C. 1983: Cambrian cephalopods. Geology 11, 647-650.

Cobbold, E. S. 1935: Cambrian faunas from Hérault, France. Ann. Mag. Nat. Hist. 16, 25-49.

Conway Morris, S. \& Peel, J. S. 1990: Articulated halkieriids from the Lower Cambrian of north Greenland. Nature 345 , 802-805.

Doguzhaeva, L. A. 1981: [Sinus in cap-shaped monoplacophorans]. Doklady Akad. Nauk SSSR 1981, 208-211. [in Russian].

Dzik, J. 1981: Origin of the Cephalopoda. Acta Palaeont. Pol. 26, 161-191.

Dzik, J. 1991: Is fossil evidence consistent with traditional views of the early metazoan phylogeny? In Simonetta, A. M. \& Conway Morris, S. (ed.) The early evolution of Metazoa and the significance of problematic taxa. 47-56. Cambridge: Cambridge Univ. Press and Univ. Camerino.
Fritz, W. H. \& Yochelson, E. L. 1988: The status of Salterella as a Lower Cambrian index fossil. Can. J. Earth Sci. 25, 403-416.

Geyer, G. 1986: Mittelkambrische Mollusken aus Marokko und Spanien. Senckenbergiana lethaea 67, 55-118.

Harper, J. A. \& Rollins, H. B. 1982: Recognition of Monoplacophora and Gastropoda in the fossil record: a functional morphological look at the bellerophont controversy. Proc. III N. Am. Paleont. Conv. 1, 227-232.

Haszprunar, G. 1988: On the origin and evolution of major gastropod groups, with special reference to the Streptoneura. Jour. Molluscan Stud. 54, 367-441.

Horny, R. J. 1963a: On the systematic position of cyrtonelloids (Mollusca). Casopis národ. Mus. Praze 132, 90-94.

Horny, R. J. 1963b: Lower Palaeozoic Monoplacophora and patellid Gastropoda (Mollusca) of Bohemia. Sbor. Ústred. Úst. Geol. 38, 7-83.

Horny, R. J. 1963c: New finds of Silurian Drahomirinae (Monoplacophora) in Bohemia and notes on their ontogeny and bionomy. Čas. národ. Mus. Praze 132, 79-89.

Horny, R. J. 1965a: Cyrtolites Conrad, 1838 and its position among the Monoplacophora (Mollusca). Sbor. národ. Mus. Praze 21, 2, 57-70.

Horny, R. J. 1965b: On the systematical position of Cyrtolites Conrad, 1838 (Mollusca). Cas. národ. Mus. Praze 134, 8-10.

Horny, R. J. 1970: Muscle scars and outer shell sculpture of Retipilina Horny (Mollusca, Monoplacophora). Čas. národ. Mus. Praze 137, 9-16.

Horny, R. J. 1990: Muscle scars in Sinuites (Strangulites) (Mollusca) from the Ordovician of Bohemia. Cas. národ. Mus. Praze 155 (for 1986), 109-118.

Horny, R. J. in press a: Shell morphology and muscle scars of Sinuitopsis neglecta Perner (Mollusca, Monoplacophora). Cas. národ. Mus. Praze.

Horny, R. J. in press b: Muscle scars in Sinuites (Mollusca, Gastropoda) from the Lower Ordovician of Bohemia. Cas. národ. Mus. Praze.

Jell, P. A. 1978: Mollusca. McGraw Hill yearbook science and technology, 1976, 269-271. New York: McGraw Hill.

Kerber, M. 1988: Mikrofossilien aus Unterkambrischen Gesteinen der Montagne Noire, Frankreich. Palaeontographica A 202, 127-203.

Knight, J. B. 1947: Bellerophont muscle scars. Jour. Paleont. 21, 264-267.

Knight, J. B. 1952: Primitive fossil gastropods and their bearing on gastropod classification. Smithson. Misc. Colls 114, $13,1-55$.

Knight, J. B., \& Yochelson, E. L. 1960: Monoplacophora. In Moore, R. C. (ed.) Treatise on Invertebrate Paleontology, I, Mollusca 1, I77-I84. Lawrence: Univ. Kansas Press and Geol. Soc. Am.

Knight, J. B., Cox, L. R., Keen, A. M., Batten, R. L., Yochelson, E. L. \& Robertson, R. 1960: Systematic descriptions. In Moore, R. C. (ed.) Treatise on Invertebrate Paleontology, I, Mollusca 1, I169-I310. Lawrence: Univ. Kansas Press and Geol. Soc. Am.

Kobayashi, T. 1987: The ancestory of the Cephalopoda. Proc. Japan Acad. 63, ser. B, 135-138. 
Koken, E. \& Perner, L. 1925: Die Gastropoden des baltischen Untersilurs. Mém. Acad. Sci. Russie, Leningrad 37, 1-326.

Krasilova, I. N. 1987: The oldest representatives of the bivalve mollusks. Paleont. Jour. 1987, 4, 21-26.

Landing, E. 1989: Paleoecology and distribution of the Early Cambrian rostroconch Watsonella crosbyi Grabau. Jour. Paleont. 63, 566-573.

Lauterbach, K. E. 1983a: Gedanken zur Enstehung der mehrfach paarigen Exkretionsorgane von Neopilina (Mollusca, Conchifera). Zeitschr. zool. Syst. \& Evolutionsforsch. 21, 38-52.

Lauterbach, K. E. 1983b: Erörterungen zur Stammesgeschichte der Mollusca, insbesondere der Conchifera. Zeitschr. zool. Syst. \& Evolutionsforsch. 21, 201-216.

Lemche, H. 1957: A new living deep-sea mollusc of the Cambro-Devonian Class Monoplacophora. Nature 179, 413-416.

Lemche, H. \& Wingstrand, K. G. 1959: The anatomy of Neopilina galatheae Lemche, 1957. Galathea Rept 3, 9-71.

Lindström, G. 1884: On the Silurian Gastropoda and Pteropoda of Gotland. K. svenska Vetenskaps Akad. Handl. 19, 250 pp.

Linsley, R. M. 1977: Some 'laws' of gastropod shell form. Paleobiology 3, 196-206.

Linsley, R. M. 1978: Shell form and evolution of the gastropods. Amer. Sci. 66, 432-441.

Linsley, R. M. \& Kier, W. M. 1984: The Paragastropoda: a proposal for a new class of Paleozoic Mollusca. Malacologia 25, 241-254.

Linsley, R. M. \& Peel, J. S. 1983: Gonad pouches in a new clam-like monoplacophoran from the Silurian of Sweden. Lethaia 16, 273-280.

MacKinnon, D. I. 1982: Tuarangia paparua n. gen. and n. sp., a late Middle Cambrian pelecypod from New Zealand. Jour. Paleont. 56, 589-598.

MacKinnon, D. I. 1985: New Zealand late Middle Cambrian molluscs and the origin of Rostroconchia and Bivalvia. $\mathrm{Al}$ cheringa 9, 65-81.

Marek, L. \& Yochelson, E. L. 1976: Aspects of the biology of the Hyolitha (Mollusca). Lethaia 9, 65-82.

Missarzhevsky, V. V. 1989: [Oldest skeletal fossils and stratigraphy of Precambrian and Cambrian boundary beds]. Trudy Ordena Trydov. Kras. Zhameni geol. Inst. Akad. Nauk SSSR 443, 237 pp. [in Russian].

Missarzhevsky, V. V. \& Mambetov, A. J. 1981: [Stratigraphy and fauna of Cambrian and Precambrian boundary beds of Maly Karatau]. Trudy Ordena Trydov. Kras. Zhameni geol. Inst. Akad. Nauk SSSR 326, 92 pp. [in Russian].

Moore, R. C. 1941: Upper Pennsylvanian gastropods from Kansas. Bull. Kansas geol. Surv. 38, 121-163.

Morton, J. E. 1979: Molluscs (5th edition). London: Hutchinson, $264 \mathrm{pp}$.

Müller, K. J. 1975: 'Heraultia' varensalensis COBBOLD (Crustacea) aus dem unteren Kambrium, der älteste Fall von Geschlechtsdimorphismus. Paläont. Zeitschr. 49, 168-180.

Peel, J. S. 1972: Observations on some Lower Palaeozoic tremanotiform Bellerophontacea (Gastropoda) from North America. Palaeontology 15, 412-422.

Peel, J. S. 1974: Systematics, ontogeny and functional mor- phology of Silurian trilobed bellerophontacean gastropods. Bull. geol. Soc. Denmark 23, 231-264.

Peel, J. S. 1976: Musculature and systematic position of Megalomphala taenia (Bellerophontacea, Gastropoda) from the Silurian of Gotland. Bull. geol. Soc. Denmark 25, 49-55.

Peel, J. S. 1977a: Relationship and internal structure of a new Pilina (Monoplacophora) from the Late Ordovician of Oklahoma. Jour. Paleont. 51, 116-122.

Peel, J. S. 1977b: Systematics and palaeontology of the Silurian gastropods of the Arisaig Group, Nova Scotia. Biol. Skr. Dansk Videnskabs. Selsk. 21(2), 89 pp.

Peel, J. S. 1978: Faunal succession and mode of life of Silurian gastropods in the Arisaig Group, Nova Scotia. Palaeontology 21, 285-306.

Peel, J. S. 1979: Protowenella (Mollusca) from the Cambrian of Greenland. Rapp. Grønlands geol. Unders. 91, 92 only.

Peel, J. S. 1980a: A new Silurian retractile monoplacophoran and the origin of the gastropods. Proc. Geol. Assoc. 91, 91-97.

Peel, J. S. 1980b: Yochelcionellids from the Early and Late Cambrian of North Greenland. Rapp. Grønlands geol. Unders. 101, 44 only.

Peel, J. S. 1982: Muscle scars in Bellerophon recticostatus (Mollusca) from the Carboniferous of Ireland. Jour. Paleont. 56, 1307-1310.

Peel, J. S. 1984: Autecology of Silurian gastropods and monoplacophorans. Spec. Pap. Palaeontology 32, 165-182.

Peel, J. S. 1987: Class Gastropoda. In Boardman, R. S., Cheetham, A. H. \& Rowell, A. J. (ed.) Fossil Invertebrates, 304-329. Palo Alto, Oxford, London: Blackwell Scientific Publications.

Peel, J. S. 1988a: Yochelcionella americana (Mollusca) from the Lower Cambrian of Newfoundland. Can. J. Earth Sci. 24, 2328-2330.

Peel, J. S. 1988b: Molluscs of the Holm Dal Formation (late Middle Cambrian), central North Greenland. Meddr Grønland Geosci. 20, 145-168.

Peel, J. S. 1989: A Lower Cambrian Eotebenna (Mollusca) from Arctic North America. Can. J. Earth Sci. 26, 15011503.

Peel, J. S. 1990a: Morphology and systematic position of Tryblidium Canadense Whiteaves, 1884 (Mollusca) from the Silurian of North America. Bull. geol. Soc. Denmark 38, 43-51.

Peel, J. S. 1990b: Studying the early history of life in Greenland. Rapp. Grønlands geol. Unders. 148, 54-56.

Peel, J. S. 1991a: Functional morphology of the Class Helcionelloida nov., and the early evolution of the Mollusca. In Simonetta, A. \& Conway Morris, S. (ed.) The early evolution of Metazoa and the significance of problematic taxa, 157-177. Cambridge: Cambridge Univ. Press and Univ. Camerino.

Peel, J. S. 1991b: Introduction. Articulated halkieriids and microchitons. Bull. Grønlands geol. Unders. 161 (this volume).

Peel, J. S. 1991c: Salpingostomatiform and related bellerophontacean gastropods from Greenland and the Baltic region. Bull. Grønlands geol. Unders. 161 (this volume). 
Peel, J. S. \& Berg-Madsen, V. 1988: A new salterellid (Phylum Agmata) from the upper Middle Cambrian of Denmark. Bull. geol. Soc. Denmark 37, 75-82.

Peel, J. S. \& Yochelson, E. L. 1982: A review of Salterella (Phylum Agmata) from the Lower Cambrian in Greenland and Mexico. Rapp. Grønlands geol. Unders. 108, 31-39.

Peel, J. S. \& Yochelson, E. L. 1987: New information on Oelandia (Mollusca) from the Middle Cambrian of Sweden. Bull. geol. Soc. Denmark 36, 263-273.

Pei Fang 1985: First discovery of Yochelcionella from the Lower Cambrian of China and its significance. Acta Micropalaeont. Sinica 2, 395-400.

Pojeta, J., Jr. 1980: Molluscan phylogeny. Tulane Studies in Geol. Paleont. 16, 55-80.

Pojeta, J., Jr. 1987: Class Rostroconchia. In Boardman, R. S., Cheetham, A. H. \& Rowell, A. J. (ed.) Fossil invertebrates, 358-380. Palo Alto, Oxford, London: Blackwell Scientific Publications.

Pojeta, J., Jr. \& Runnegar, B. 1976: The paleontology of rostroconch molluscs and the early history of the Phylum Mollusca. [U. S.] geol. Surv. Prof. Pap. 968, 88 pp.

Pojeta, J., Jr. \& Runnegar, B. 1979: Rhytiodentalium kentuckyensis, a new genus and species of Ordovician scaphopod, and the early history of scaphopod mollusks. Jour. Paleont. 53, 530-541.

Pojeta, J., Jr., Gilbert-Tomlinson, J. \& Shergold, J. H. 1977: Cambrian and Ordovician rostroconch molluscs from northern Australia. Bull. Bur. Mines Min. Res., Geol. Geophys. (Austr.) 171, 1-54.

Poulsen, C. 1927: The Cambrian, Ozarkian and Canadian faunas of Northwest Greenland. Meddr Grønland 70(1), 2, 233-343.

Poulsen, C. 1932: The Lower Cambrian faunas of East Greenland. Meddr Grønland 87(6), $66 \mathrm{pp}$.

Poulsen, C. 1958: Contribution to the palaeontology of the Lower Cambrian Wulff River Formation. Meddr Grønland 162(2), $25 \mathrm{pp}$.

Qian Yi \& Bengtson, S. 1989: Palaeontology and biostratigraphy of the Early Cambrian Meishucunian Stage in Yunnan Province, South China. Fossils and Strata 24, 156 pp.

Raaben, M. E. (ed.) 1981: The Tommotian Stage and the Cambrian lower boundary problem, 359 pp. New Delhi: Amerind Publ. Co. [English translation of Rozanov et al., 1969].

Ramsköld, L. \& Hou Xianguang 1991: New early Cambrian animal and onychophoran affinities of enigmatic metazoans. Nature 351, 225-228.

Rasetti, F. 1954: Internal shell structures in the Middle Cambrian gastropod Scenella and the problematic genus Stenothecoides. Jour. Paleont. 28, 59-66.

Robison, R. A. 1964: Late Middle Cambrian faunas from western Utah. Jour. Paleont. 38, 510-566.

Rolfe, W. D. I. 1981: Septemchiton - a misnomer. Jour. Paleont. 55, 675-678.

Rollins, H. B. 1969: The taxonomic position of Cyrtonella mitella (Hall) (Mollusca, Monoplacophora). Jour. Paleont. 43, 136-140.
Rollins, H. B. \& Batten, R. L. 1968: A sinus-bearing monoplacophoran and its role in the classification of primitive molluscs. Paleont. 11, 132-140.

Rozanov, A. Yu., Missarzhevsky, V. V., Volkova, N. A., Voronova, L. G., Krylov, I. N., Keller, B. M., Korolyuk, I. K., Lendzion, K. , Michniak, R., Pykhova, N. G. \& Sidorov, A. D. 1969: [The Tommotian Stage and the problem of the lower boundary of the Cambrian]. Trudy Geologicheskogo Inst. Akad. Nauk SSSR 296, 380 pp. [in Russian., see Raaben (1981) for the English translation].

Rozov, S. N. 1968: A new genus of Late Cambrian mollusks of the Class Monoplacophora (southern part of the Siberian platform). Doklady Akad. Nauk SSSR 183, 214-217. [translated from Novy rod pozdnekembriyskikh mollyuskov iz klassa monoplakofor (yuzhnaya chast' Sibirskoy platformy). Doklady Akad. Nauk SSSR 183, 1427-1430].

Rozov, S. N. 1969: Morphology and terminology of Monoplacophora. Paleont. Jour. 1969, 4, 548-551.

Rozov, S. N. 1975: A new order of the Monoplacophora. Paleont. Jour. 1975, 1, 39-43.

Runnegar, B. 1978: Origin and evolution of the Class Rostroconchia. Phil. Trans. R. Soc. London B 284, 319-333.

Runnegar, B. 1981: Muscle scars, shell form and torsion in Cambrian and Ordovician univalved molluscs. Lethaia 14, 311-322.

Runnegar, B. 1983: Molluscan phylogeny revisited. Mem. Assoc. Australas. Palaeont. 1, 121-144.

Runnegar, B. 1985: Shell microstructure of Cambrian molluscs replicated by phosphate. Alcheringa 9, 245-257.

Runnegar, B., \& Jell, P. A. 1976: Australian Middle Cambrian molluses and their bearing on early molluscan evolution. Alcheringa 1, 109-138.

Runnegar, B., \& Jell, P. A. 1980: Australian Middle Cambrian molluscs: corrections and additions. Alcheringa 4, 111-113.

Runnegar, B., \& Pojeta, J., Jr. 1974: Molluscan phylogeny: the paleontological viewpoint. Science 186, 311-317.

Runnegar, B., \& Pojeta, J., Jr. 1980: The monoplacophoran mollusk Yochelcionella identified from the Lower Cambrian of Pennsylvania. Jour. Paleont. 54, 635-636.

Runnegar, B., \& Pojeta, J., Jr. 1985: Origin and diversification of the Mollusca. In Trueman, E. R. \& Clarke, M. R. (ed.) The Mollusca 10, Evolution, 1-57. Orlando: Academic Press.

Runnegar, B., Pojeta, J., Morris, N. J., Taylor, J. D. \& McClung, G. 1975: Biology of the Mollusca. Lethaia 8, 181-191.

Runnegar, B., Pojeta, J., Taylor, M. E. \& Collins, D. 1979: New species of the Cambrian and Ordovician chitons Matthevia and Chelodes from Wisconsin and Queensland: evidence for the early history of polyplacophoran mollusks. Jour. Paleont. 53, 1374-1394.

Salvini-Plawen, L. von 1980: A reconsideration of systematics in Mollusca (phylogeny and higher classification). Malacologia 19, 247-278.

Salvini-Plawen, L. von 1981: On the origin and evolution of the Mollusca. Origine dei grandi Phyla dei Metazoi, Atti dei Convegni Lincei, Accad. Naz. dei Lincei 49, 235-293. 
Salvini-Plawen, L. von 1985: Early evolution and the primitive groups. In Trueman, E. R. \& Clarke, M. R. (ed.) The Mollusca 10, Evolution, 59-150. Orlando: Academic Press.

Schmidt, F. 1888: Über ein neuentdeckte unterkambrische Fauna. Mém. Acad. Sci., St. Petersbourg, 7 ser. 36, 1-29.

Signor, P. W., \& Kat, P. W. 1984: Functional significance of columellar folds in turritelliform gastropods. Jour. Paleont. 58, 210-216.

Smith, A. G. 1960: Amphineura. In Moore, R. C. (ed.) Treatise on Invertebrate Paleontology, I, Mollusca 1, I41-I76. Lawrence: Univ. Kansas Press and Geol. Soc. Amer.

Stanley, S. M. 1975: Adaptive themes in the evolution of Bivalvia (Mollusca). Ann. Rev. Earth Planet. Sci. 3, 361385.

Starobogatov, Ya. I. 1970: Systematics of Early Paleozoic Monoplacophora. Paleont. Jour. 1970, 3, 293-302.

Stasek, C. R. 1972: The molluscan framework. In Florkin, M. \& Scheer, B. T. (ed.) Chemical Zoology, 1-44. New York: Academic Press.

Stinchcomb, B. L. 1980: New information on Late Cambrian Monoplacophora Hypseloconus and Shelbyoceras (Mollusca). Jour. Paleont. 54, 45-49.

Stinchcomb, B. L. 1986: New Monoplacophora (Mollusca) from Late Cambrian and Early Ordovician of Missouri. Jour. Paleont. 60, 606-626.

Stinchcomb, B. L. \& Echols, D. J. 1966: Missouri Upper Cambrian Monoplacophora previously considered cephalopods. Jour. Paleont. 40, 647-654.

Swedmark, B. 1968: The biology of interstitial mollusca. Symp. Zool. Soc. London 22, 135-149.

Sysoyev, V. A. 1984: The morphology and systematic position of the hyoliths. Paleont. Jour. 1984, 2, 1-10.

Teichert, C. 1988: Main features of cephalopod evolution. In Clarke, M. R. \& Trueman, E. R. (ed.) The Mollusca 12, Palaeontology and neontology of cephalopods, 11-75. Orlando: Academic Press.

Vermeij, G. J. 1975: Evolution and distribution of left-handed and planispiral coiling in snails. Nature 254, 419-420.

Vermeij, G. J. \& Dudley, E. C. 1985: Distribution of adaptations: a comparison between the functional shell morphology of freshwater and marine pelecypods. In Trueman, E. R. \& Clarke, M. R. (ed.) The Mollusca 10. Evolution, 461-478. Orlando: Academic Press.

Voronova, L. G., Drosdova, N. A., Esakova, N. B., Zhegallo, E. A., Zhuravlev, A. Yu., Rozanov, A. Yu., Sayutina, T. A. \& Ushatinskaya, G. T. 1987: [Lower Cambrian fossils of the MacKenzie Mountains (Canada)]. Trudy Paleont. Inst. Akad Nauk SSSR 224, 88 pp. [in Russian].

Wade, M. 1988: Nautiloids and their descendants: cephalopod classification in 1986. Mem. New Mexico Bur. Mines Min. Res. 44, 15-25.

Warmke, G. L. \& Almodovar, L. R. 1963: Some associations of marine molluses and algae in Puerto Rico. Malacologia 1, 163-177.

Webers, G. F. \& Yochelson, E. L. 1989: Late Cambrian molluscan faunas and the origin of the Cephalopoda. In Crame, J. A. (ed.) Origins and evolution of the Antarctic biota. Spec. Publ. geol. Soc. London 47, 29-42.
Webers, G. F., Pojeta, J., Jr., \& Yochelson, E. L. in press: Cambrian Mollusca from the Minaret Formation, Ellsworth Mountains, West Antarctica. In Webers, G. F., Craddock C. \& Splettstoesser, J. (ed.) The geology and paleontology of the Ellsworth Mountains, west Antarctica. Mem. geol. Soc. Amer. 170.

Wenz, W. 1940: Ursprung und frühe Stammesgeschichte der Gastropoden. Arch. Molluskenk. 72, 1-10.

Westergård, A. H. 1936: Paradoxides oelandicus beds of Öland with the account of a diamond boring through the Cambrian at Mossberga. Sver. geol. Unders. C, 394, 66 pp.

Wingstrand, K. G. 1985: On the anatomy and relationships of Recent Monoplacophora. Galathaea Rept 16, 7-94.

Yochelson, E. L. 1963: Problems of the early history of the Mollusca. Proc. XVI Internat. Congr. Zool. Washington D.C. 2, 187 only.

Yochelson, E. L. 1967: Quo vadis, Bellerophon? In Teichert, C. \& Yochelson, E. L. (ed.) Essays in paleontology and stratigraphy, 141-161. Lawrence: Univ. Kansas Press.

Yochelson, E. L. 1968: Stenothecoida, a proposed new class of Cambrian Mollusca. Abstr. Internatl Paleont. Union, Prague, Czechoslovakia, 34 only.

Yochelson, E. L. 1969: Stenothecoida, a proposed new class of Cambrian Mollusca. Lethaia 2, 49-62.

Yochelson, E. L. 1970: The Early Cambrian fossil Salterella conulata Clark in eastern North America. [U.S.] Geol. Surv. Prof. Pap. 683-B, B1-10.

Yochelson, E. L. 1977: Agmata, a proposed extinct phylum of Early Cambrian age. Jour. Paleont. 51, 437-454.

Yochelson, E. L. 1978: An alternative approach to the interpretation of the phylogeny of ancient mollusks. Malacologia 17, 165-191.

Yochelson, E. L. 1979: Early radiation of Mollusca and mollusc-like groups. In House, M. R. (ed.) The origin of the major invertebrate groups, 323-358. New York: Academic Press.

Yochelson, E. L. 1981: A survey of Salterella (Phylum Agmata). U.S. Geol. Survey Open-file Report 81-743, 244-248.

Yochelson, E. L. 1988: A new genus of Patellacea (Gastropoda) from the Middle Ordovician of Utah: the oldest known example of the superfamily. Mem. New Mexico Bur. Mines Min. Res. 44, 195-200.

Yochelson, E. L. \& Gil-Cid, D. 1984: Reevaluation of the systematic position of Scenella. Lethaia 17, 331-340.

Yochelson, E. L. \& Nuelle, L. M. 1985: Strepsodiscus (Gastropoda) in the Late Cambrian of Missouri. Jour. Paleont. 59, 733-740.

Yochelson, E. L. \& Peel, J. S. 1980: Early Cambrian Salterella from North-west Greenland. Rapp. Grønlands geol. Unders. 101, 29-36.

Yochelson, E. L. \& Stanley, G. D. 1981: An early Ordovician patelliform gastropod, Palaelophacmaea, reinterpreted as a coelenterate. Lethaia 15, 323-330.

Yochelson, E. L., Flower, R. H., \& Webers, G. F. 1973: The bearing of the new Late Cambrian monoplacophoran genus Knightoconus upon the origin of the Cephalopoda. Lethaia 6, 275-310.

Yonge, C. M. 1960: General characters of Mollusca. In Moore, 
R. C. (ed.) Treatise on Invertebrate Paleontology I, Mollusca 1, 13-I36, Lawrence: Univ. Kansas Press and Geol. Soc. Amer.

Yonge, C. M., \& Thompson, T. E. 1976: Living marine Molluscs. London: Collins, $288 \mathrm{pp}$

Yu Wen 1987: Yangtze micromolluscan fauna in Yangtze Region of China, with notes on Precambrian-Cambrian boundary. Stratigraphy and palaeontology of systematic boundaries in China. Precambrian-Cambrian Boundary (1), 19-344. Nanjing: Nanjing Univ. Publ. House.
Yu Wen 1989: Did the shelled mollusks evolve from univalved to multivalved forms or vice versa? Developments in Geoscience. Contribution to 28th International Geological Congress, 1989, Washington D.C., U.S.A., 235-244. Chinese Acad. Sci., Beijing: Science Press.

Yu Wen 1990: The first radiation of shelled molluscs. Palaeontologia cathayana 5, 139-170.

Yu Wen \& Ning Hui 1985: Two Cambrian monoplacophorans from Borohore, Xinjiang. Acta Palaeont. Sin. 24, 47-50. 


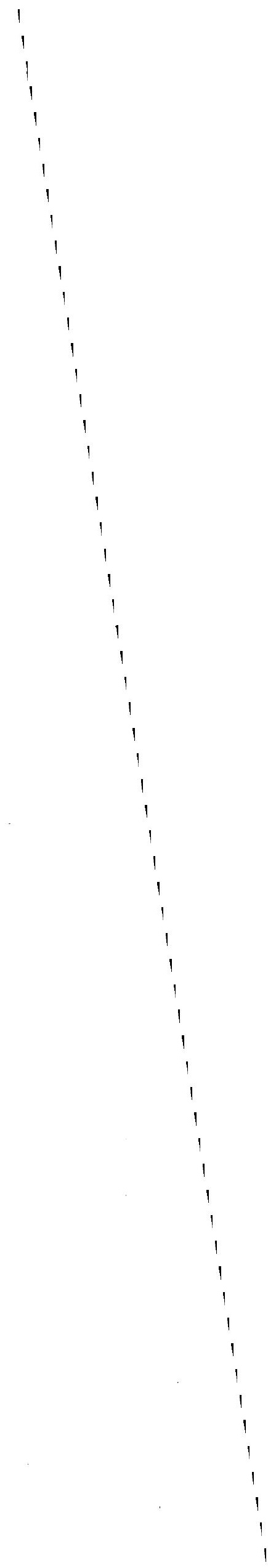




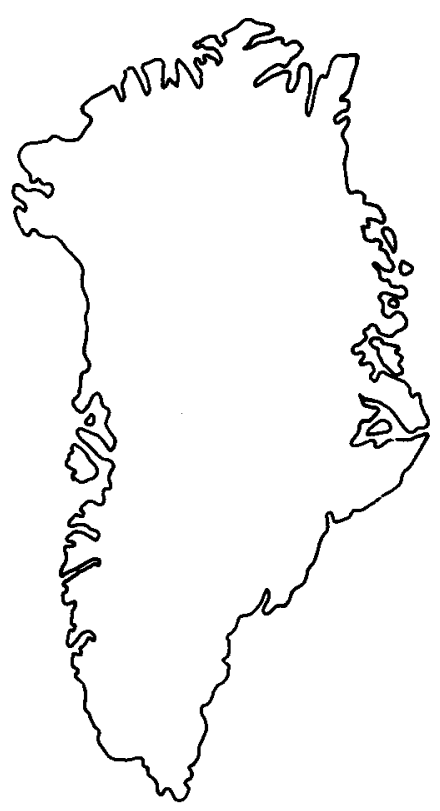

\title{
Salpingostomatiform and related bellerophontacean gastropods from Greenland and the Baltic region
}

\author{
John S. Peel \\ The development of a median dorsal perforation, termed a trema, in bellerophonta- \\ cean gastropods is discussed with reference to Silurian species from Greenland and \\ Sweden. The description for the first time of a single trema in the genera Bucania and \\ Megalomphala indicates that acquisition of a trema is not in itself diagnostic of the \\ genus Salpingostoma, as previously supposed, although the latter genus is still recog- \\ nised. \\ Salpingostoma and Megalomphala are redescribed on the basis of Ordovician type \\ and topotype material from Estonia. The new species Salpingostoma martinssoni, \\ Megalomphala gotlandica, $M$. marjorae, $M$. wilfredi and Bucania stephnae are de- \\ scribed from the Silurian of Gotland, Sweden. Megalomphala dawesi and Bucania \\ groenlandica are proposed from the Silurian of North Greenland, while Salpingos- \\ toma septentrionale is reassigned to Megalomphala. \\ Offleya, known only from the Silurian of North Greenland, is considered to be \\ closely related to Phragmolites and both genera are transferred to the Sub-family \\ Bucaniinae. The status of the bellerophontacean genera Tremanotus and Boiotremus, \\ in which a series of dorsal tremata is present, is reviewed.
}

J. S. P., Geological Survey of Greenland, $\emptyset$ ster Voldgade 10, DK-1350 Copenhagen $\mathrm{K}$, Denmark.

The group of molluscs resembling Bellerophon de Montfort, 1808 (Fig. 1) is conspicuous throughout the Palaeozoic and its members are characterised by a bilaterally symmetrical, un-chambered shell which is coiled within a single plane. The occurrence of a median dorsal emargination in the aperture of these bellerophontiform molluscs has played a central role in discussions of their systematic position ever since their first description. Robert Plot (1686), in what Challinor (1945) considered to be the earliest reference to the group, clearly recognised that the specimen before him, a Bellerophon from the Carboniferous of North Staffordshire, United Kingdom, could not be assigned to a living animal. Any relationship to the similarly coiled living Nautilus Linné, 1758 was rejected since the fossil specimen preserved a feather-like pattern on the dorsum not present in the living cephalopod. Plot's illustration demonstrates that this feather-like pattern is the selenizone, generated by the median dorsal slit, and the growth lines which gradually curve from the lateral areas in towards this band (Fig. 1E).

By the middle of the last century it was widely accepted that Bellerophon and related taxa were gastropods, although placement within the class was not 5* agreed (see discussion by Yochelson, 1967). However, ideas formulated by de Koninck (1842-44) and Meek (1866; see also Lindström, 1884) that the median dorsal emargination in bellerophontiform molluscs indicated a relationship with pleurotomarian prosobranch gastropods gathered support to become the prevailing doctrine.

Wenz (1940) questioned the assignment of all the bellerophontiform taxa to the Gastropoda, by reference to a specimen of Cyrtonella mitella (Hall, 1862) from the Devonian of Michigan, U.S.A., a form without a median dorsal emargination, in which he described paired dorsal muscle scars believed to indicate a lack of torsion. Wenz (1940) placed Bellerophon and its relatives together with tryblidiaceans such as Pilina Koken \& Perner, 1925 and Tryblidium Lindström, 1880 within the Sub-class Amphigastropoda, characterised by a lack of torsion. Thus, Wenz anticipated the concept of the Class Monoplacophora in the wider sense of at least some later authors (e.g., Runnegar \& Pojeta, 1974).

Knight (1947) refuted the general conclusion of Wenz (1940) which was based on the atypical (for the bellerophontacean group) Cyrtonella. He described muscle scars in the slit-bearing Carboniferous Bellerophon and 

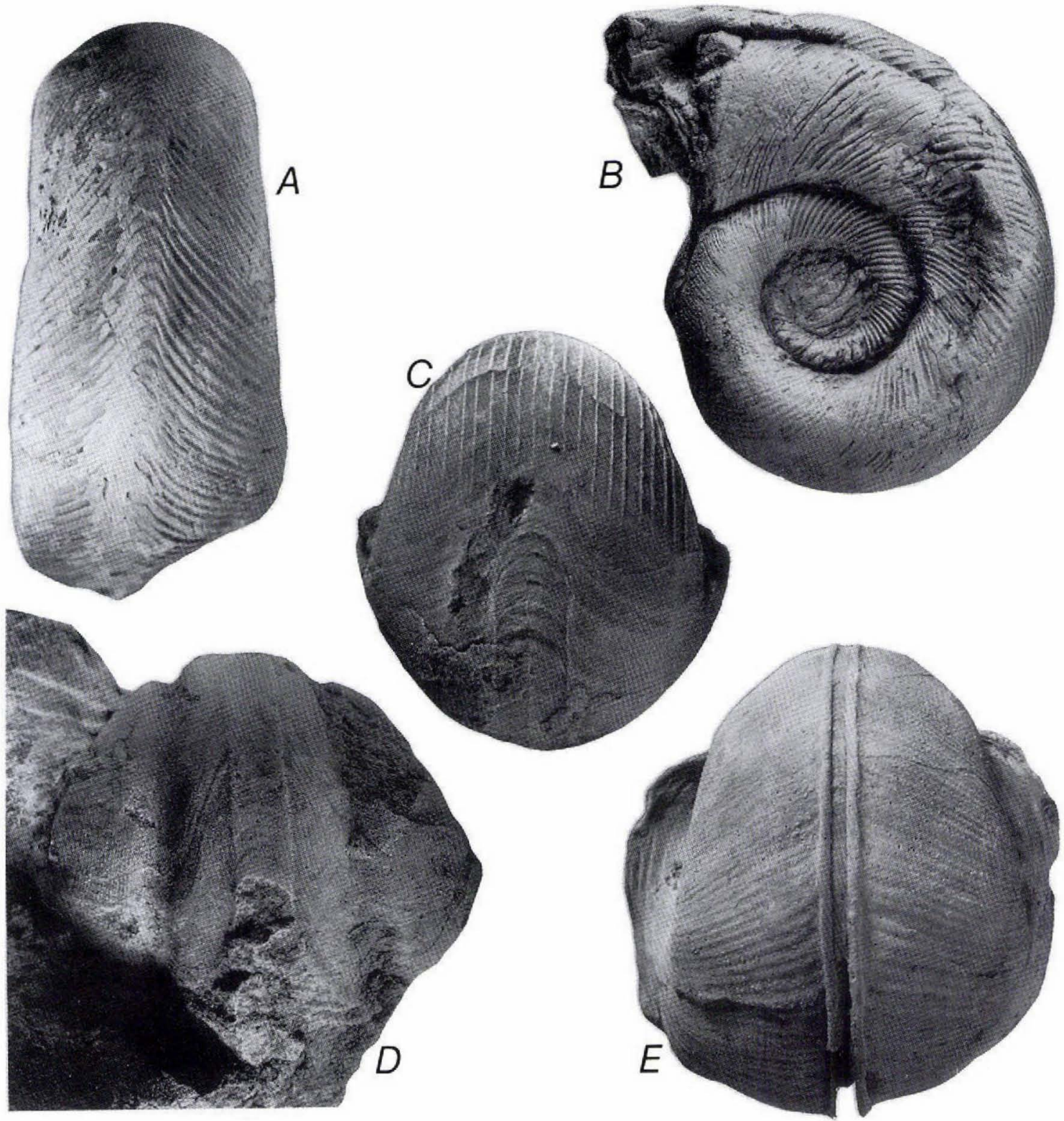

Fig. 1. Bellerophontacean gastropods. A, B, Modestospira poulseni Yochelson, 1964 from the Lower Ordovician Orthoceras Limestone of Store Duegaard, Bornholm, Denmark. Holotype, MMH 9.953, $\times 2$, in dorsal and lateral views. Modestospira is characterised by its loosely coiled whorls, wide umbilici (B) and the median dorsal sinus (A). C, Euphemites jacksoni (Weir, 1931) from the Carboniferous (Namurian) of Congleton Edge, Cheshire, U.K. Topotype, MGUH 16.783, $\times 4$. In this globose bellerophontacean a broad slit generates a selenizone which, atypically for the group, is only visible in the latest part of the whorl due to the deposition of a strongly ribbed outer shell layer. D, Plectonotus boucoti Peel, 1974 from the Lower Silurian, near Llandeilo, Wales, U. K., NMW $39.180 \mathrm{G14}, \times 2$, in dorsal view to show the well developed selenizone and slit and the strongly trilobed dorsum. E, Bellerophon de Montfort, 1808. Lower Carboniferous, Belgium, MGUH 20.837, $\times 2$. Silica replica showing the median dorsal selenizone ornamented with lunulae and bounded between spiral cords. The combination of the selenizone and the growth ornamentation on the dorso-lateral areas formed the feather-like structure noted by Plot (1686). 
the sinuate Ordovician Sinuites Koken, 1896 which he considered to indicate torsion, by comparison with living primitive pleurotomarian prosobranch gastropods. Knight (1947) transferred Cyrtonella to the Tryblidiacea, which he accepted as untorted following Wenz (1940), but considered Bellerophon, Sinuites and their relatives, including Cyrtolites Conrad, 1838, to be gastropods.

The description of Neopilina by Lemche (1957; see also Lemche \& Wingstrand, 1959 and Wingstrand, 1985), following closely on the major study of early molluscs by Knight (1952), added new impetus to the search for ancestral molluses or their Neopilina-like descendants (such as Pilina and Tryblidium) in the fossil record. At first, the role of shell musculature in the form of muscle scars on the shell interior, occupied a central position in this discussion, with new and conflicting information stimulating a controversy about the position of the bellerophontiform molluscs and the scope of the Class Monoplacophora which continues to this day (Peel, 1991a, b abandoned the term Class Monoplacophora in formal systematics, placing Neopilina and its immediate relatives in a new Class Tergomya).

A functional morphological approach to the interpretation of the dorsal median emargination in bellerophontiform molluses was taken by Knight (in Moore, 1941; 1952) in his analysis of Knightites Moore, 1941, from the Carboniferous of Kansas, U.S.A., confirming the association with exhalation from the mantle cavity. The same theme was followed by Peel (1974) with regard to the dorsally trilobed genera Plectonotus Clarke, 1899 (Fig. 1D) and Tritonophon Öpik, 1953 which were also considered to be gastropods.

Rollins \& Batten (1968) added a new perspective to the debate by describing a dorsal emargination in a strongly coiled Devonian bellerophontiform mollusc with multiple paired muscle scars which they assigned to Sinuitopsis Perner, 1903 (Horny, 1990, in press a, has recently described musculature in the type species of Sinuitopsis from the Ordovician of Bohemia). Thus, the seeds of doubt were cast concerning the significance of the dorsal emargination as a simple indicator of gastropod affinities; the homology between the slit and supposed torsion of the isostrophic Bellerophon and the slit-bearing, torted, but anisostrophic pleurotomarians was threatened, at least in the eyes of some protagonists, with Bellerophon being interpreted as a slit-bearing, but untorted, mollusc (Runnegar \& Pojeta, 1974; Runnegar \& Jell, 1976, but see discussion by Harper \& Rollins, 1982). The significance of the discussion was heightened by the traditional role taken by the form of the dorsal emargination in the classification of belle- rophontiform molluscs (e.g. Knight et al., 1960; Horny, 1963).

Linsley $(1977 ; 1978)$ and McNair et al. (1981) developed a framework for the interpretation of gastropod shell form based on the examination of living faunas. Their conclusions inevitably require adjustment as new parameters are added (cf. Harper \& Rollins, 1982, p. 228 ) but still provide a set of ground rules for functional analysis of gastropod and gastropod-like molluscs. Their conclusions are naturally derived from their experience as gastropod workers. A background in other molluse groups, such as the Bivalvia, might lead to different interpretations, as seems to be exemplified by the model of molluscan evolution developed by Runnegar \& Pojeta (1974) and discussed by Yochelson (1978) and Peel (1991a, b).

A median dorsal emargination in bellerophontiform molluscs can no longer be interpreted as automatically indicative of gastropod affinity; such emarginations are also present in the coiled shells of some untorted cyrtonellid Tergomya (cf. Peel, 1991b). Neither is the function of the emargination exclusively in terms of providing the locus of the exhalant current from the mantle cavity, although this role is always dominant. In forms such as Sinuites the increased size of the median sinus reflects the development of prosocyrt shell margins which extend along the side of the body as protective lateral shields (Horny, 1990, in press b). Similar shields are described in Beyrichidiscus Linsley \& Peel, 1983 from the Silurian of Gotland and also in helcionelloids such as Anabarella or the supposed ancestral rostroconch Watsonella (see Runnegar \& Jell, 1976; Peel, 1991b).

The same sanitary arguments related to the development of a median emargination in bellerophontiform gastropods can be applied with equal weight to untorted bellerophontiform molluscs (Rollins \& Batten, 1968) and to other molluscan groups such as the helcionelloids Eotebenna Runnegar \& Jell, 1976 and Yochelcionella Runnegar \& Pojeta, 1980, referred to a new Class Helcionelloida by Peel, (1991a, b). To a large extent, acquisition of the resultant sinus, slit or trema is influenced by other shell features such as rate of expansion and mode of life. Inevitably, realisation of the functional benefits of the median dorsal emargination has tended to undo some of the emphasis previously placed on the form of the emargination in the classification of fossil gastropods (Yochelson, 1984; Yochelson \& Nuelle, 1985).

This paper evaluates a specific modification of the median dorsal emargination which has been used as a 


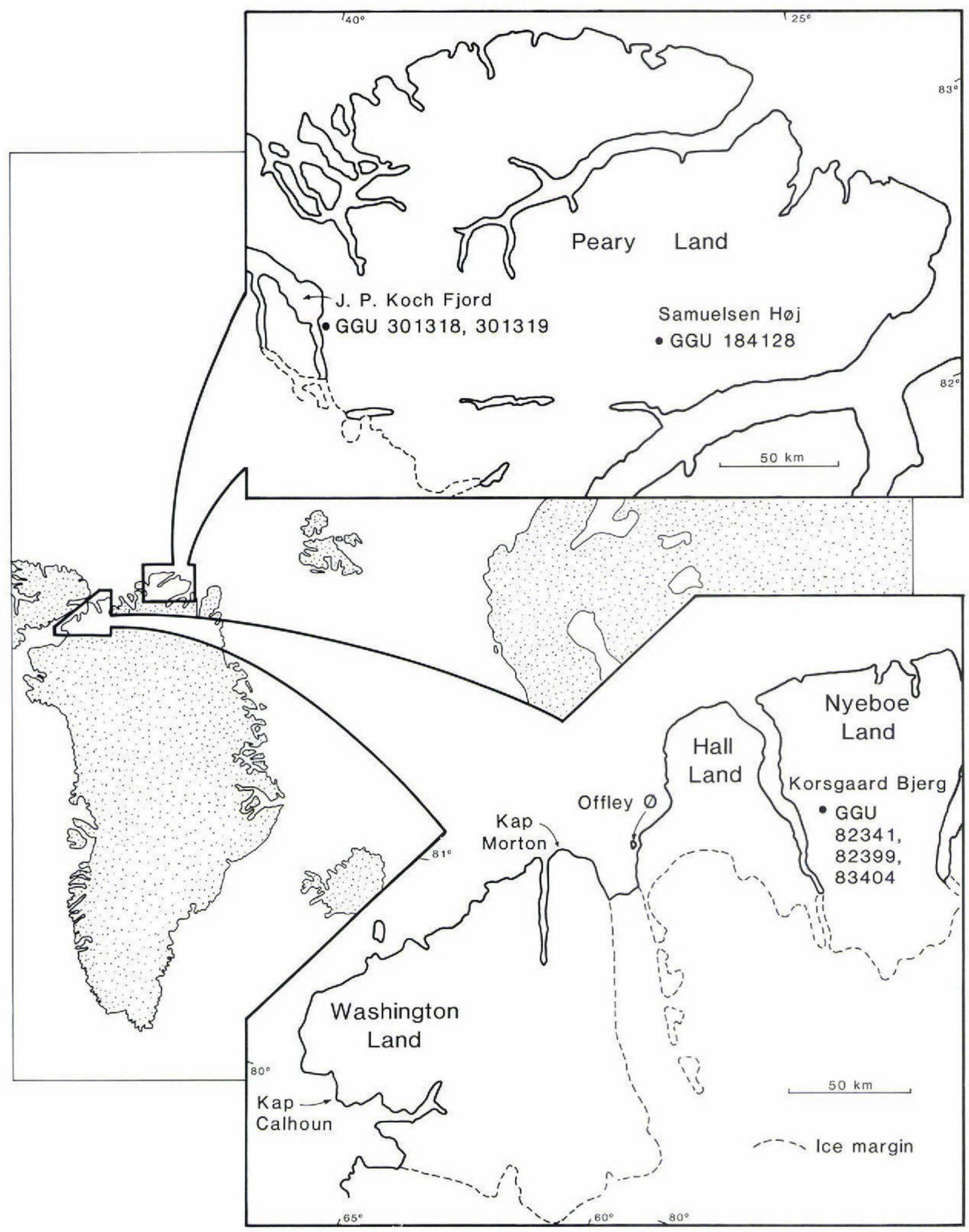

Fig. 2. Localities in North Greenland mentioned in the text. 

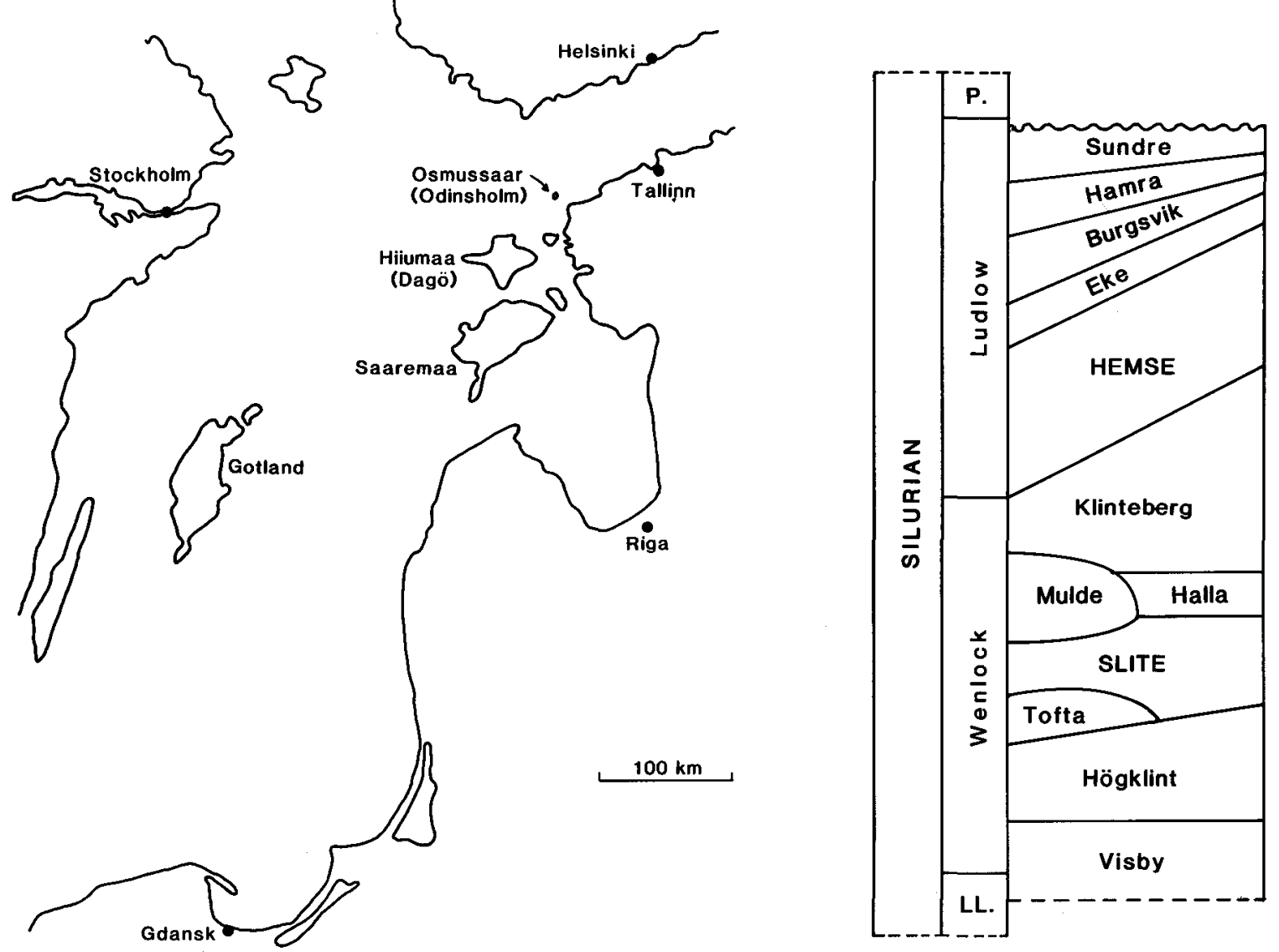

Fig. 3. Localities in the eastern Baltic mentioned in the text together with a summary of the Silurian stratigraphy of Gotland (after Bassett et al., 1989). Formations are listed in lower case, groups in upper case. LL, Llandovery; P, Pridoli.

basis for the recognition of at least two genera of bellerophontacean gastropods, namely the development of dorsal perforations or tremata. One genus (Tremanotus Hall, 1865) derives its name directly from the presence of a row of tremata, while another genus (Salpingostoma Roemer, 1876) is traditionally delimited from its supposed ancestor (Bucania Hall, 1847) by conversion of the slit to a single elongate trema in the later growth stages.

Bellerophontaceans with a single dorsal trema and some associated taxa from the Silurian of North Greenland (Fig. 2) and Gotland, Sweden (Fig. 3), are described below and their generic relationships assessed. A necessary preliminary is the redescription of the type species of two of the principal genera, namely Salpingostoma and Megalomphala Ulrich in Ulrich \& Scofield, 1897, from the Ordovician of Estonia.

It is concluded that modification of the median dorsal emargination to form a trema is not in itself a diagnostic generic character since the feature occurs in Salpingostoma, Megalomphala and Bucania. However, both genera proposed with reference to their trema (tremata), namely Salpingostoma and Tremanotus, can still be recognised. Boiotremus Horny, 1962, described as a descendant of Tremanotus, is probably its junior synonym.

Offleya Poulsen, 1974, an unusual bellerophontacean only described from the Lower Silurian of North Greenland, is revised and considered to be more closely related to Phragmolites Conrad, 1838 than to Salpingostoma. All three genera, however, are referred to the Sub-family Bucaniinae.

Salpingostoma septentrionale Poulsen, 1974, also from the Silurian of North Greenland, is re-assigned to Megalomphala. Seven new species of Bucania, Megalomphala and Salpingostoma are proposed. 


\section{The tremate condition in Salpingostoma and related bellerophontacean gastropods}

\section{Bucania, Megalomphala and Salpingostoma}

Ulrich \& Scofield (1897) proposed the Family Bucaniidae to include several earlier described genera and a number of new forms. A restricted Bucania Hall, 1847, type species Bucania sulcatina (Emmons, 1842), was characterised by generally wide umbilici and ornamentation in which revolving and transverse growth elements are conspicuous. Ulrich in Ulrich \& Scofield (1897) proposed Megalomphala for a group of bellerophontaceans that Koken (1889) had referred to as the 'Gruppe des Bellerophon contortus'.

"The general form of the shell and volutions in these species is precisely as in the typical section of Bucania, as here restricted and defined. They may, however, be distinguished at once by the total absence of revolving surface striae" (Ulrich in Ulrich \& Scofield, 1897, p. 850 ).

The type of Megalomphala was stated to be Bellerophon contortus Eichwald, 1860 from the Ordovician of the island of Dagö (Hiiumaa), Estonia (Fig. 3). Ulrich considered both Megalomphala and Bucania to be typically Ordovician genera, although he followed Koken (1889) in including Bellerophon taenia Lindström, 1884, from the Silurian of Gotland within Megalomphala.
The type material of Megalomphala contorta is deposited in Leningrad and was not examined by Knight (1941), who reproduced Eichwald's (1860) original figure. This figure was also reproduced by Wenz (193844), Knight et al. (1960, fig. 96, 2a, b) and Vostokova (1960). The figure illustrates an unusual ornamentation of strongly prosocyrt growth lines, delimiting some form of lateral apertural shields (Fig. 4B), the shape of which is difficult to reconcile with the implied close relationship to Bucania, where growth lines usually slope obliquely backwards (adapically) from the suture towards the median dorsal area on account of the tangential aperture. Within the bellerophontiform molluscs, similar lateral shields to the aperture are principally known from Sinuites Koken, 1896 which bears little morphological resemblance to Megalomphala contorta (Horny, 1990; see also Horny, in press b).

Knight (1941) and Knight et al. (1960) chose not to refer back to the various North European Ordovician species referred to Megalomphala by Koken \& Perner (1925), although it is evident that these latter authors must have been familiar with Eichwald's species.

Megalomphala is re-described here on the basis of the type specimen of Bellerophon contortus from Leningrad, and interpreted with reference to Silurian speci-
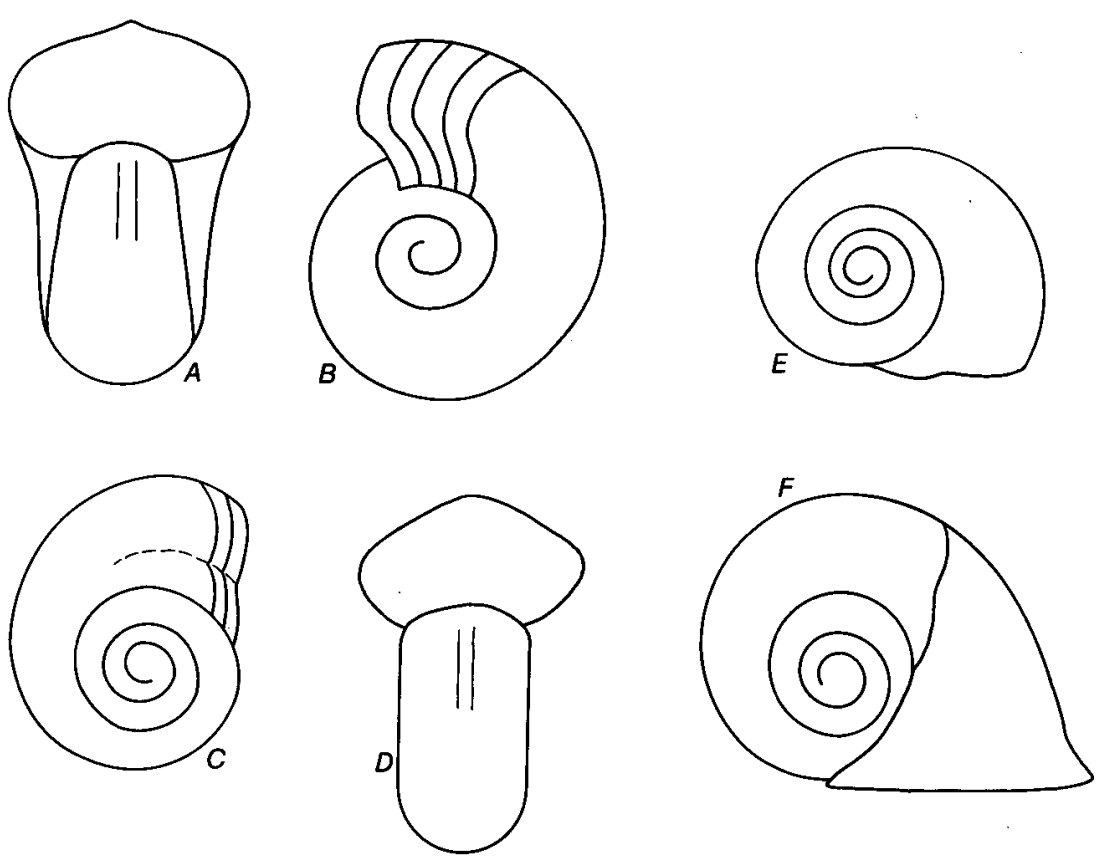

Fig. 4. Megalomphala Ulrich in U1rich \& Scofield, 1897. A, B, schematic drawing of the illustration given by Eichwald (1860) and reproduced by Knight (1941), Wenz (1938-44), Vostokova (1960) and Knight et al. (1960). Note the aperture is incorrectly shown to be radial and prosocyrt, with lateral shields, when viewed laterally. C, D, schematic drawing of the holotype of Megalomphala contorta (Eichwald, 1860) based on Fig. 24C. Note the aperture is tangential, opisthocline, with a shallow emargination developed at the angular whorl periphery. E, Megalomphala in life position with the tangential aperture parallel to the sediment interface. F, Megalomphala as illustrated in E restored in life position after the development of a bell-shaped aperture. Note the anterior and posterior expansion of the aperture. 
mens from Greenland and Sweden. Photographs of the type specimen from Leningrad were kindly made available by Soviet colleagues. Ellis L. Yochelson loaned plaster casts of the same specimen made by himself and currently deposited in the U.S. National Museum of Natural History.

The single feature used by Ulrich in Ulrich \& Scofield (1897) to delimit the genus from Bucania, namely the absence of spiral ornamentation in Megalomphala, is a useful if not completely reliable indicator, although all of the Silurian species described below and most of the Ordovician species of Megalomphala described by Koken \& Perner (1925) appear to preserve a simple transverse ornamentation of growth lines. However, a new species of Bucania described below from the Silurian of Gotland, Sweden, lacks any form of spiral ornament. So also does $B$. robusta (Whiteaves, 1904) which was originally described as a species of Megalomphala (cf. Whiteaves, 1906) but is here re-assigned to Bucania.

In delimiting Megalomphala, emphasis is placed on the loose coiling (i.e. the slight degree of overlap of successive whorls), high number of whorls (5 or 6), slow rate of whorl expansion and corresponding extremely wide umbilici which, together with the bucaniiform configuration of a broad median dorsal sinus and narrow slit, seem to be characteristic. These characters are valuable in separating the genus from another problematic Ordovician genus, Salpingostoma Roemer, 1876, as discussed below.

The sickle-shaped growth ornamentation of the frequently repeated drawing of Megalomphala made by Eichwald (1860) results from inadequate appreciation of perspective during draughting. Growth lines do not swing forward from the suture with the previous whorl to produce the lateral shields (Fig. 4B). Rather, they curve strongly backwards (adapically) from the suture across the umbilical wall towards the peripheral dorsolateral shoulders (Fig. 4E-F, see also Figs 24C, E, F, below). As the growth lines cross this prominent angulation they become transverse to the whorl, gradually curving backwards towards the median dorsal slit (Figs 4, 24A).

The combination of the peripheral angulation and the slight changes in curvature of the growth lines produces the 'sickle' shape, but this lacks any significant prosocyrt curvature of the type implied by Eichwald's artist (Fig. 4B). Thus, the growth lines of Megalomphala are typically bucaniiform in shape.

An added consequence of the combination of the curvature of the growth lines and the peripheral angulation in Megalomphala is the formation of shallow emarginations at each dorso-lateral angulation (Fig. 4C). These emarginations are readily interpreted as marking the location of the inhalant water currents to the mantle cavity, by reference to the functional interpretations of the bellerophontacean gastropods Knightites and Plectonotus and Tritonophon made by Knight (1952) and Peel $(1974,1984)$. Indeed, effective separation of the inhalant currents from the de-oxygenated median dorsal exhalant current may have promoted the development of the angular dorso-lateral margins seen in many species of Megalomphala.

Ulrich \& Scofield (1897) also placed Salpingostoma, with type species Bellerophon megalostoma Eichwald, 1840 from the Ordovician of Estonia, within the Family Bucaniidae to "... include shells whose inner volutions correspond in nearly every respect with the whole shell of the most typical species of Bucania, and it is only in full grown entire examples that the peculiarities of the genus are apparent. These consist in the abrupt development of a thick and greatly expanded aperture and in the anterior closing of the long dorsal apertural slit" (Ulrich \& Scofield, 1897, p. 897).

Salpingostoma megalostoma is poorly known, the type material in the University of Leningrad, U.S.S.R., consisting solely of a single broken aperture (see Fig. 19, below). However, well preserved topotype material in the collections of the Paleozoological Department of Naturhistoriska Riksmuseet, Stockholm, Sweden, indicates a shell with about four whorls (Figs 20-22, below), producing relatively narrower umbilici than in Megalomphala. The earliest three and a half whorls have a lenticular profile with width greater than height. Pronounced expansion of the dorsum is evident in the fourth whorl, ultimately forming the bell-shaped final growth stage. The expansion is initially to the anterior, producing a highly vaulted dorsum, but also takes place to each side and to a lesser extent to the rear, producing increased impression of the previous whorl. The margin of the aperture flares and becomes explanate in the final growth stage.

The dorsum in Salpingostoma megalostoma shows a median slit which generates a well-developed selenizone. The slit fails to penetrate the youngest quarter of the whorl (it is not closed as Ulrich \& Scofield suggested), leaving a single, elongate, dorsal perforation (trema) about one sixth of the whorl circumference in length. It is the anterior expansion of the shell and this single trema which serve to delimit Salpingostoma from Bucania. Both genera usually show ornamentation of crenulate lamellae which may produce a spiral or reticulate pattern, and a similar number of whorls.

In summary, the separation of the three genera Bucania, Megalomphala and Salpingostoma suggested by Ulrich \& Scofield (1897) appears well founded, with only moderate revision of the characters used for delim- 


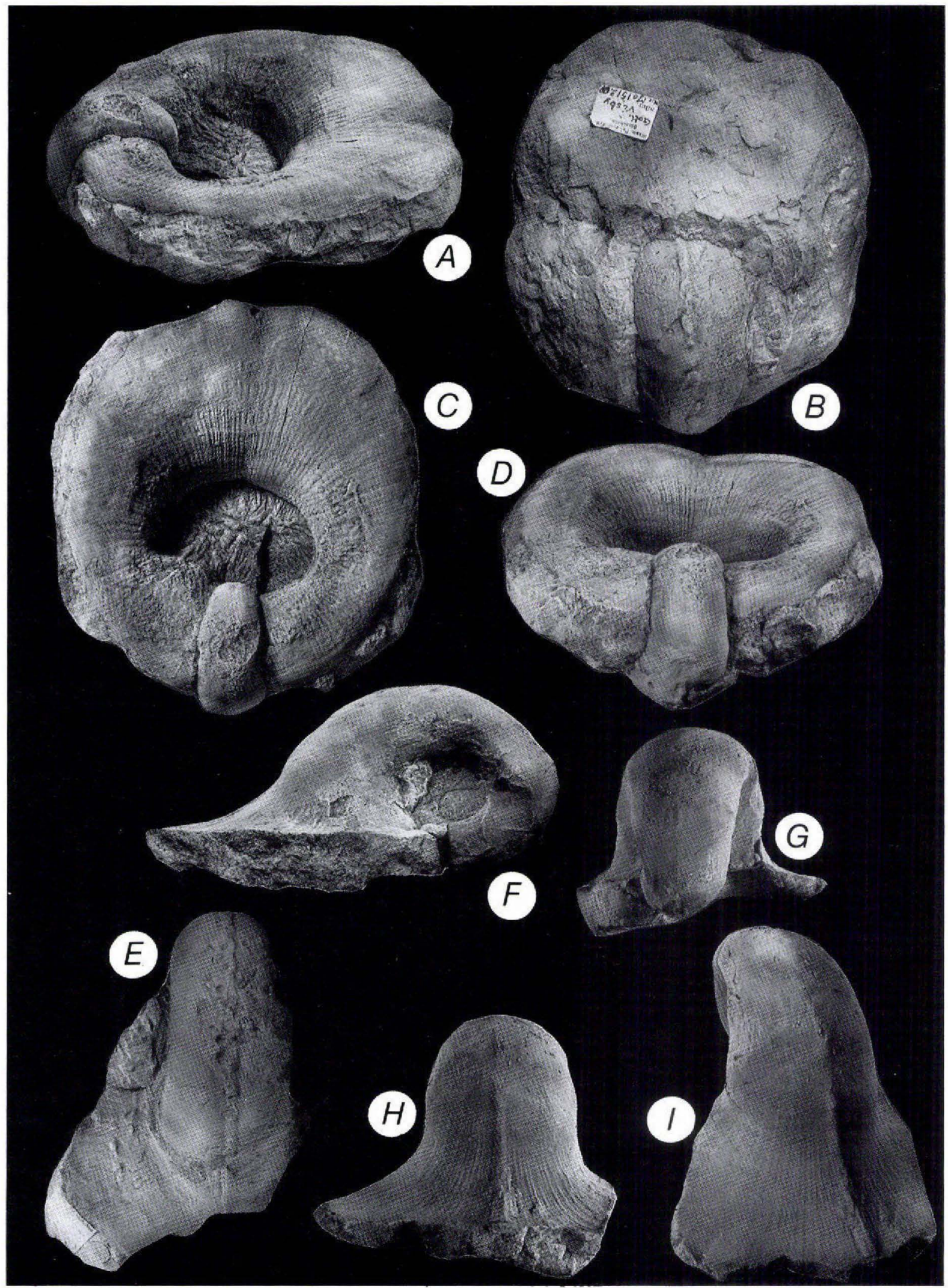


itation. It was not without surprise, therefore, that description of the currently available Silurian material from Greenland and Sweden demonstrates that one supposedly diagnostic character, the absence of the slit in the latest growth stage in association with expansion of the aperture, occurs in species assigned to all three genera.

\section{The Tremanotus problem}

Tremanotus Hall, 1865 is another genus placed within the Family Bucaniidae by Ulrich \& Scofield (1897). Tremanotus, based on the species $T$. alpheus Hall, 1865 from the Silurian of Illinois, U.S.A., is a large, loosely coiled bellerophontacean gastropod with an expanded aperture and a series of perforations (tremata) along the median dorsal plane prior to the final flaring of the apertural margins. The type species was re-described by Knight (1941), with reference to well preserved material from the Silurian of New York State described by Clarke \& Ruedemann (1903). Species answering to this general description are widespread in Silurian and Devonian strata from North America (Peel, 1972) to Europe (Horny, 1963) and Australia (Tassell, 1976), although only fragmentary examples are currently known from the Silurian of North Greenland (J. S. Peel, unpublished observation).

Two species have been described from the Silurian of Gotland, Sweden, Tremanotus longitudinalis Lindström, 1884 (Fig. 5) and Tremanotus compressus Lindström, 1884 (Fig. 6).

Horny $(1962,1963)$ described a new genus Boiotremus, with type species Tremanotus fortis Frech, 1894

Fig. 5. Tremanotus longitudinalis Lindström, 1884, Lower Silurian, Visby Formation, Visby, Gotland, Sweden, internal moulds preserved in mudstone, $\times 0.70$. A-D, Mo 151209 , oriented up-side-down in A, C, D. A, D, oblique apertural views showing the widely expanded aperture carrying the impre ed ornamentation of the upper surface of the shell. Note the $\mathrm{n}_{\mathrm{t}}$ argins of the aperture curve upwards and that there is an anterior sinus; $\mathrm{B}$, dorsal view with the expanded aperture buried in sediment, showing the median dorsal tremata; $\mathbf{C}$, apertural view, anterior at the top, showing the absence of tremata in the explanate portion of the expanded aperture. $\mathrm{E}$, Mo 26903, internal mould in antero-dorsal view, here designated as lectotype, being the specimen illustrated by Lindström (1884, plate 4, figs 2, 3) from the Lower Visby Formation at Visby. Subsequent to engraving of Lindström's illustration, this specimen has lost part of the widely expanded brim. F-I, Mo 26934, internal mould with most of the aperture broken away. F, lateral view; $\mathbf{G}$, posterior view; $\mathbf{H}$, anterior view; $\mathbf{I}$, oblique antero-dorsal view. from the Lower Devonian of central Europe, which supposedly differed from Tremanotus in possessing tremata throughout ontogeny; those on the dorsum of the final whorl were open but previous tremata were closed by a calcareous plug. Horny considered Tremanotus to be characterised by tremata only in the final growth stage, without any indication of their presence in earlier growth stages, basing his observations on a sequence of 10 species of Tremanotus and Boiotremus distributed through Silurian and Devonian strata in Bohemia.

Horny (1963, p. 97) related the development of tremata to the acquisition of an expanded aperture. He considered the absence of the tremata in the early stages of Tremanotus to indicate a phylogentic relationship with the sinuitid bellerophontaceans (in which the median dorsal emargination consists of a sinus, without slit or selenizone) rather than the slit-bearing bellerophontids (in Fig. 1, the bellerophontacean Modestospira Yochelson, 1964 shows a sinus while Bellerophon, Plectonotus Clarke, 1899 and Euphemites Wartin, 1930 show a sinus passing into a slit which generates a selenizone). Boiotremus was considered to represent the further development of this trend from sinuitids to Tremanotus with formation of tremata throughout ontogeny (cf. Horny, 1963, fig. 10).

Motivated by the presence of the single dorsal trema in Salpingostoma, Horny (1963) grouped this genus, together with Tremanotus and Boiotremus, into a Family Salpingostomatidae Koken, 1925, standing close to the sinuitid bellerophontaceans. This contrasts with the placement of the Tribe Salpingostomatides (containing Salpingostoma and Tremanotus) within the Sub-family Bucaniinae of the Family Bellerophontidae by Knight $e t$ al. (1960).

Peel (1972) accepted Horny's separation of Tremanotus and Boiotremus but pointed out that Salpingostoma was a typical bucaniinid, with a slit developed throughout ontogeny until the final fraction of the final whorl. He could not reconcile the supposedly basically sinuitid emargination of Tremanotus with the slit-bearing Salpingostoma, and abandoned the Family Salpingostomatidae sensu Horny (1963). Salpingostoma was returned to the Bucaniinae but a new Sub-family Tremanotinae Peel, 1972 of the Family Sinuitidae Dall in Zittel-Eastman, 1913 was proposed to accomodate Boiotremus and the nominate genus, following the morphological arguments proposed by Horny (1963).

Peel (1972) briefly reviewed North American tremanotinids using the number, size and separation of the dorsal tremata as the character for distinguishing between Tremanotus and Boiotremus. Species from Bohemia referred to Tremanotus by Horny (1963) are characterised by a low number of widely spaced open tremata, 


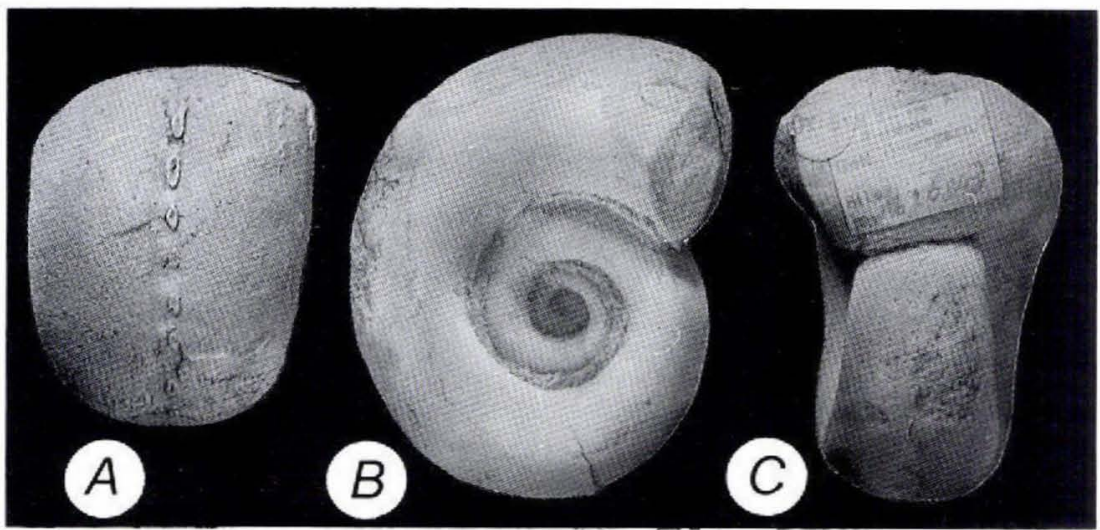

Fig. 6. Tremanotus compressus Lindström, 1884, Silurian, Hemse Group, Östergarn, Gotland, Sweden. Mo 26843, internal mould lacking the aperture, here designated as lectotype, being the specimen figured by Lindström (1884, plate 4 , figs 8,9$)$. A, dorsal view of latest preserved growth stage showing the numerous and closely spaced tremata, $\times 1 ; \mathrm{B}$, lateral view showing the similar coiling to the contemporaneous Megalomphala taenia (Lindström, 1884), × 1.2; C, apertural view, $\times 1$.

while the open tremata in Boiotremus are more numerous and closely spaced. Peel adopted this approach since most North American material available to him was in the form of internal moulds in dolomite, lacking any trace of the development of tremata in early whorls.

Tassell (1976) placed Boiotremus in synonymy with Tremanotus, commenting that Horny's separation of the former was based on a misunderstanding of Knight's (1941) redescription of the type species of Tremanotus. Knight (1941, p. 354) stated that "from six to eight tremata remaining open... with the still earlier ones filled", although there is no indication that tremata are developed throughout ontogeny.

Through the kindness of Dr. Radvan J. Horny (National Museum, Prague) it has been possible to examine Bohemian tremanotinids during a visit to Czechoslovakia in May 1990. The material in question is well-described by Horny and his assertion that specimens which he assigned to Tremanotus show no preserved trace of early tremata is correct. However, most of the specimens in question are preserved as internal moulds which lack traces of the closed tremata on the surface of the mould, or shell in the appropriate part of the whorl. In contrast, most of the Boiotremus species are very well preserved and show tremata throughout ontogeny.

The absence of traces of closed tremata in Bohemian Tremanotus probably reflects the presence of a thin layer of shell material deposited on the shell interior after the individual tremata were abandoned and closed. This would also explain the absence of tremata in the early stages of many of the North American specimens preserved in dolomite which were discussed by Peel (1972). However, it was not possible to conclusively demonstrate the presence of closed tremata in any specimens from Bohemia assigned to Tremanotus by Horny (1963). Thus, at the present time, the synonymisation of Boiotremus with Tremanotus undertaken by Tassell (1976) is not restated with conviction, although there is evidence to suggest that such a step is justified. It is possible that separation of the two genera may be feasible on the basis of the size and separation of open tremata, as practised by Peel (1972).

While doubt exists about the number of recognisable genera of tremanotinins, it is clear that species assigned to the sub-family share with Salpingostoma, and some species of Megalomphala and Bucania, the lack of a slit penetrating the final growth stage of the apertural margin.

Following the criteria proposed by Horny (1963), both Lindström's (1884) species from the Silurian of Gotland, Sweden should be assigned to Boiotremus. Indeed, Horny (1963) considered Tremanotus longitudinalis Lindström, 1884 to be a typical representative of his new genus (Fig. 5).

The Gotland material is not redescribed here, partly on account of the generic uncertainty, but also due to the need for clarification of the relationship of the Swedish species to two previously described British species, namely Tremanotus dilatatus (Sowerby in Murchison, 1839) and T. aymestriensis (Sowerby in Murchison, 1839). Lindström (1884) was to some extent aware of this close relationship but the descriptions available to him from Sowerby (in Murchison, 1839) were wanting to such a degree that even the generic relationships of the illustrated British specimens were uncertain. Newton (1892a) described a new species of Tremanotus (under the emended, but invalid, spelling Trematonotus Fischer, 1883) in ignorance of Lindström's publication, before later in the same volume acknowledging his oversight and placing $T$. longitudinalis and his own $T$. britannicus into synonymy with $T$. dilatatus (Newton, 1892b).

Reed (1920-21) considered both of Lindström's (1884) species of Tremanotus to be possible junior synonyms of the British species described by Sowerby in Murchison (1839) but without comment. Unfortu- 
nately, the latter material is neither adequately described nor illustrated, at the present time; in particular, the respective type specimens are poorly preserved. Until such revision can be attempted, it is considered unwise to synonymise Lindström's (1884) well-described and well-illustrated species with their probable, but poorly known, British counterparts. However, as an aid to future revision, lectotypes are here selected for the two Gotland species (Figs 5, 6).

\section{The tremate condition}

The presence of tremata in Tremanotus has played an historically important role in the classification of the bellerophontaceans as prosobranch gastropods. Meek (1866) claimed that Tremanotus offered as nearly a positive demonstration of the affinities of the Bellerophongroup as probably can be expected when, by reference to $T$. chicagoensis (McChesney, 1859), he drew parallels between the tremate condition in Tremanotus and that in fossil and living pleurotomarian prosobranch gastropods. Lindström (1884, p. 71) followed Meek's (1866) lead, stressing the considerable similarity in terms of shell ornamentation and the dorsal tremata between Tremanotus and the abalone Haliotis Linné, 1758. At the same time, Lindström stressed the importance of the presence of a dorsal sinus or slit in determination of gastropod affinity in isostrophic molluscan shells.

There is little debate concerning the principal function of the dorsal emargination in bellerophontacean gastropods and for more than 150 years it has been recognised as providing a conduit for the expulsion of waste products in a similar manner to the pleurotomarian slit (e.g., de Koninck, 1842-44; Meek, 1866; Lindström, 1884; Knight, 1952; Yochelson, 1967; Peel, 1974). There is, of course, considerable debate as to whether or not the presence of such an emargination alone is indicative of gastropod affinities, as discussed by Harper \& Rollins (1982) and others, and elsewhere in this paper. However, accepting the association of at least most bellerophontacean median dorsal emarginations with the exhalant function, it is evident that only at the point at which this exhalant current emerges is it necessary for the shell wall to be penetrated or invaginated.

Combination of continuous growth and the presence of an exhalant emargination in the apertural margin inevitably results in the continued presence of an emargination throughout shell ontogeny, as witnessed by the abundant growth lines representing earlier growth stages in the bellerophontacean shell. Thus, the parallel-sided emargination of Bellerophon (Fig. 1E) and Bucania (Figs 7E, 12B) generates a well-developed sele- nizone throughout ontogeny, while the V-shaped sinus of Modestospira only produces a series of invaginated growth lines en echelon (Fig. 1A, B).

Gastropod shells continue to grow throughout life, although the parameters of the logarithmic spiral vary ontogenetically as shown in the plectonotiform bellerophontaceans by Peel (1974). In old shells the rate of growth may slow down significantly and is often accompanied by, or even largely restricted to, massive thickening around the aperture, as seen in for example Bucania squamosa Lindström, 1884 (Fig. 11). If active growth of the shell spiral ceases, or almost so, the site of exhalation of excretory products and de-oxygenated water no longer needs to relocate relative to the shell, and exhalation can be achieved at a single site, through a single perforation, instead of a sinus or slit. Thus, sinuate or slit-bearing forms might be expected to develop an entire margin in their final growth stages while retaining the 'active' part of their former apertural emargination as a single trema.

The general absence of a single dorsal exhalant perforation in normally coiled slit-bearing or sinuate bellerophontaceans and pleurotomarians argues that this mechanism fails to explain the relatively rare occurrence of the tremate condition in the Gastropoda. As a simple result of declining growth and the presence of a median dorsal emargination, it might be expected to be common in forms with deep emarginations, but this is not so. However, the mechanism may be relevant in Silurian Megalomphala where the final bell-shaped growth stage shows only slight departure from the logarithmic spiral characteristic of the rest of the shell, and the slit is absent only from the final fraction of the whorl.

The same mechanism can be invoked also in Bucania squamosa but the shell is more expanded here and also massively thickened. If thickening also reflects life in more high energy environments, the simple anterior margin without a slit may contribute to shell strength, as discussed below, although concentration of thickening just in the apertural regions in some forms, with the rest of the shell being much thinner, suggests that massive apertural shell deposition did not serve a defensive role.

The lack of descriptions of trema formation in Ordovician species of Megalomphala and Bucania is unexplained. However, detection of the phenomenon requires well preserved material with unbroken apertures. Even the extensive Gotland collections in Naturhistoriska Riksmuseet, Stockholm, contain very few such specimens and here the occurrence of a trema was also overlooked by previous workers.

The formation of a single trema in Salpingostoma, instead of the open slit present during earlier growth 

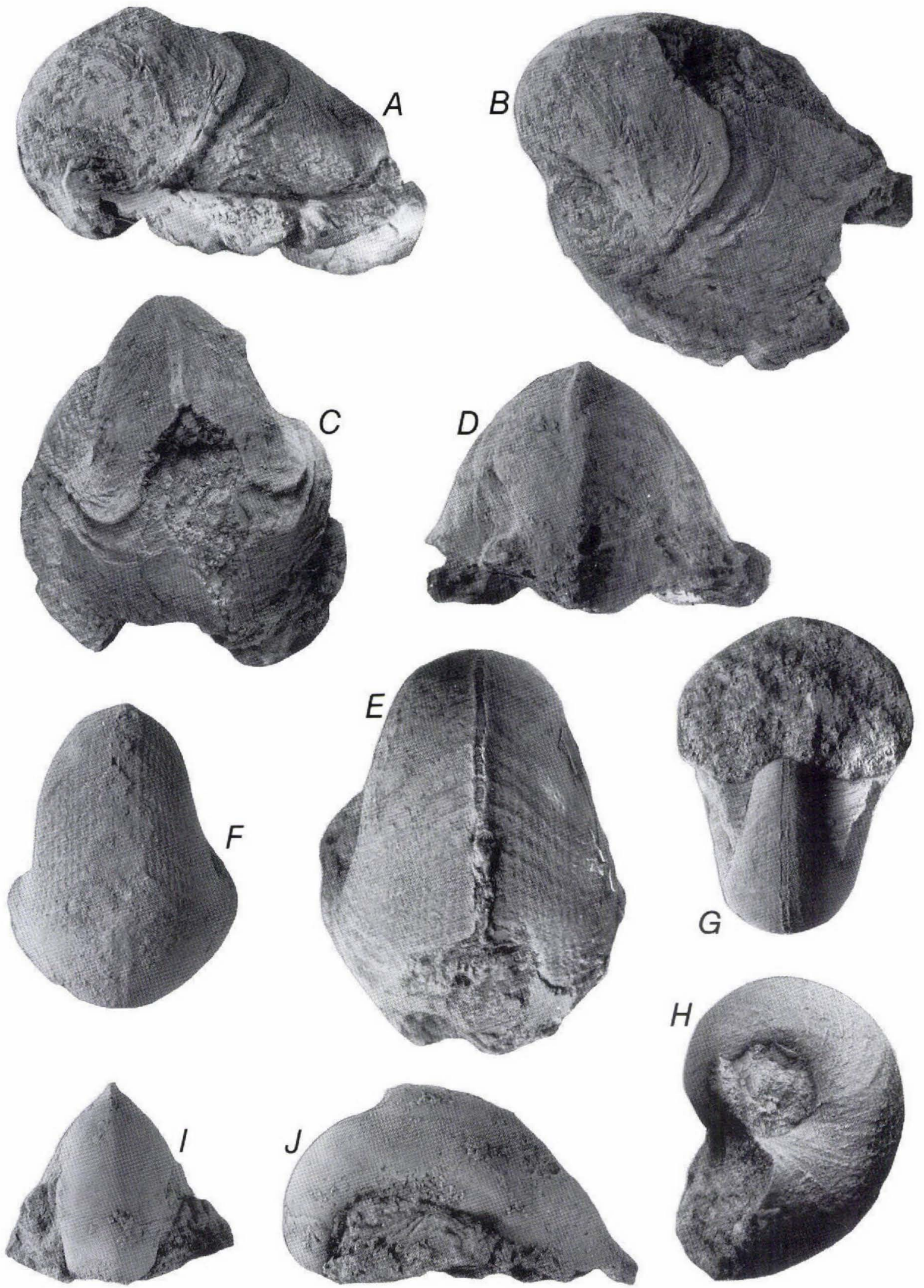
stages, can be more directly related to the bell-shaped final growth stage which tends to be more pronounced that in Megalomphala. Apertural flaring occurs only once in connection with the final growth stage. The slit does not penetrate to the anterior apertural margin simply because spiral shell growth has effectively ceased, being replaced by the addition of growth increments to the apertural margins in a plane almost perpendicular to the coiling direction (Fig. 20). Thus, the exhalant stream comes to occupy a stationary position relative to the coiled shell.

A partial analogy is offered by the key-hole limpets (Fissurellacea) where the perforation at or near the apex remains essentially static while successive growth increments are added to the apertural margin of the conical or widely expanding shell.

The presence of series of tremata throughout life in Tremanotus (and eventually also Boiotremus), Haliotis and some other pleurotomarians can not be directly explained in this manner. The living Haliotis represents an adaptation of a pleurotomarian stock to achieve a limpet-like existence. As with Tremanotus, only the last few tremata are open, with earlier ones closed by shell secretion. The presence of tremata instead of a slit in the massive shells of Haliotis clearly serves to strengthen the shell in the wave-battered, high energy environments in which it lives (cf. Yonge \& Thompson, 1976). Many Tremanotus, however, occupied quiet environments and have relatively thin shells with widely phaneromphalous umbilici unsuited to life in high energy conditions. In Gotland, Tremanotus longitudinalis occurs in life position in the mudstones of the Visby

Fig. 7. Bucania squamosa (Lindström, 1884), Silurian, Gotland, Sweden. A-D, lectotype, Mo 26456, the original of Lindström (1884, plate 5, figs 17-19), Högklint Formation at Lutterhorn (= Lauterhorn), Fårö, $\times 1.5$. A, lateral view of the rather coarsely preserved specimen showing coarse growth rugae in the final growth stage; $\mathrm{B}$, dorso-lateral view, note crenulate growth lines; $\mathrm{C}$, dorsal plan view showing the expanded and massively thickened final growth stage, the form of the deep median emargination and the raised selenizone with preserved lunulae; D, dorsal profile in posterior view. E, paralectotype, Mo 26457 , the specimen illustrated by Lindström (1884, plate 5, fig. 20-21, but shown in a different view), same locality and horizon as lectotype, $\times 4$. F-H, Mo 26707, Slite Group at Dämbar (= Dämba), Fårö, $\times 3.5$. F, dorsal view; G, apertural view, with aperture broken back to leave traces of the umbilical wall to either side of the earliest visible growth stage; H, lateral view. I, J, Mo 26787 , internal mould from Slite Group at Stora Myra, Martebo, showing the acute median dorsal crest produced by sediment filling between the upturned lamellose margins of the slit, $\times 1$.
Formation, as confirmed also by the dorso-ventral compression of many specimens in the collections of Naturhistoriska Riksmuseet, in an environmental setting quite unlike the rocky shores frequented by extant haliotids.

Ulrich \& Scofield (1897, p. 898) concluded that the absence of the median dorsal emargination from the apertural margin was an incidental result of apertural expansion, perhaps resulting from a need to avoid fracture. Examination of Boiotremus fortis (Frech, 1894), the type species of Boiotremus Horny, 1963, suggests a more direct relationship to the periodic and abrupt flaring of the aperture which characterises this Devonian species (Horny, 1963, pl. 27, fig. 3) which in terms of gross coiling morphology is very similar to Offleya inexpectata (Fig. 41). The flared stages in $B$. fortis occur immediately adapically of each trema and expand abruptly at 90 degrees to the shell spiral, forming a frill around the whorl about as wide as the diameter of the whorl itself. The couplet of flared stage and trema is repeated every few degrees of rotation around the circumference of the shell, suggesting saltation in growth from one flared stage to the next, but not implying that exhalation necessarily took place through the trema immediately adapical of the current aperture.

Evidence of previous flared stages is normally restricted to the appropriate trema and a transverse rugation representing the root of the broken away flared aperture. However, specimens with earlier flared stages preserved are known. In $B$. fortis there is clearly no point in any continuous emargination (i.e. slit) passing through this flare due to the frequent periodicity of the trema-flared aperture couplet.

In other Tremanotus species the scars of flared stages are often less conspicuous but usually can be recognised (cf. Lindström, 1884). The resultant frill need not have been wide or heavily calcified; neither should it be confused with the bell-shaped growth stage of the adult shell. The great thickening around the brim of the shell aperture in the final growth stage probably results from repeated secretion of flared lamellae without significant separating periods of spiral growth of the shell.

\section{Phragmolites, Conradella and Offleya}

Ulrich \& Scofield (1897, p. 905)) recognised the identity of their new genus Conradella with Phragmolites Conrad, 1838. They chose not to use the name Phragmolites since it was "objectionable because it gives an incorrect idea of the fossil. Conrad believed his $P$. compressus to be a chambered shell ... Had the name ever attained currency, we would feel ourselves bound to revive it, on the score of priority, despite its inappropri- 
ateness, but as no one, as far as we learn, ever adopted it, we thought it best to view the name as one that has failed of being established because of incorrect and insufficient definition."

Ulrich \& Scofield (1897) placed Conradella and their new genera Tetranota, Kokenia (renamed Kokenospira Bassler, 1915 non Kokenia Holzapfel, 1895) and Megalomphala, together with Bucania Hall, 1847, Salpingostoma Roemer, 1876, Tremanotus Hall, 1865 and $O x$ ydiscus Koken, 1889 (an objective synonym of Tropidodiscus Meek \& Worthen, 1866) in the Family Bucaniidae.

Koken \& Perner (1925, p. 69) employed Conradella for three Baltic Ordovician species, apparently considering the taxon to be a subgenus of Megalomphala. These two genera were placed together with Bucania and Oxydiscus in a 'gruppe' Bucaniinae of the Family Bellerophontidae.

Knight (1941) described both Phragmolites and Conradella in his treatise on gastropod genotypes. Knight noted that Conrad (1838) failed to figure his new genus Phragmolites and that the type or types were seemingly lost. Accordingly, Knight based his description on a specimen figured by Hall (1847), commenting that Hall was undoubtedly familiar with the types since he and Conrad were colleagues at the time that Conrad described his species. Indeed, Knight (1941, p. 242) stated that Hall's description might have been based on Conrad's type material and that the latter's material might form part of the Hall collection, from the Middle Ordovician of New York State.

Observations concerning the possible synonymy of Conradella, described on the basis of specimens from the Middle Ordovician of Minnesota, with Phragmolites lay outside the scope of Knight's (1941) study. Wenz (1938-44) placed Conradella as a junior synonym of Phragmolites within the Family Bucaniidae, an action echoed by Vostokova (1960).

Knight et al. (1960) placed Conradella as a junior synonym of Phragmolites, within the Sub-family Tropidodiscinae Knight, 1956 of the Bellerophontidae. Other genera included Tropidodiscus Meek \& Worthen, 1866, Charalostrepsis Knight, 1948 and Temnodiscus Koken, 1896. Characters of the sub-family were stated to be the narrowness of the shell, great depth of the slit and the common presence of a posterior train. The Sub-family Bucaniinae, as recognised by Knight et al. (1960), was divided into a Tribe Bucaniides (Eobucania Kobayashi, 1955, Bucania, Tetranota, Kokenospira and questionably Megalomphala) and a Tribe Salpingostomatides (Tremanotus and Salpingostoma).

The Sub-family Tropidodiscinae as employed by Knight et al. (1960) is not an homogenous group, as already demonstrated by Horny $(1962 ; 1963)$ in his removal of Temnodiscus and establishment of the new Sub-family Temnodiscinae of the Family Sinuitidae. Temnodiscus lacks the deep slit supposedly characteristic of tropidodiscinids. Joleaudella Patte, 1929, which Knight et al. (1960) placed as a junior synonym of Tropidodiscus, was considered to be a cymbulariinid by Peel $(1977$, p. 19). These two genera are essentially only similar to Tropidodiscus in terms of their narrow (i.e., laterally compressed) shells.

Phragmolites, while commonly being laterally compressed, should also be removed from the Tropidodiscinae since the shape of its median sinus is quite unlike that seen in Tropidodiscus itself. In the latter genus growth lines curve strongly backwards (adapically) from the suture, producing a deep V-shaped sinus which gradually deepens to form a deep, narrow slit. In Phragmolites, the growth lines indicate that the aperture was tangential, without the strong convexity characteristic of the growth lines of Tropidodiscus. The median sinus is very wide and shallow and passes quite angularly into the narrow median slit. This type of emargination is also developed in Bucania and Megalomphala. Phragmolites also differs from Tropidodiscus in having whorls with a more rounded profile, lacking the sub-triangular shape characteristic of the latter form, a feature which doubtless is reflected in the shape of the sinus.

In consequence, Phragmolites Conrad, 1838 is transferred from the Tropidodiscinae to the Sub-family Bucaniinae, to lie in close proximity to Bucania, Salpingostoma and Megalomphala. Offleya Poulsen, 1974, originally assigned to the Tribe Salpingostomatides by Poulsen (1974), is considered to be more closely related to Phragmolites than to Salpingostoma.

\section{Systematic conclusions}

The description of a trema in the body whorl of Megalomphala and Bucania demonstrates that this feature alone has little significance as a delimiting generic feature in Salpingostoma. A trema may be expected to occur in other bellerophontaceans of similar morphology, or possibly also in slit-bearing pleurotomarians. Likewise, it may occur in some species assigned to a genus, and not in others.

Recognition of Salpingostoma as a distinct genus is not affected by this conclusion, since the genus offers a combination of characters which serve to clearly distinguish it from either Bucania or Megalomphala. These include the bell-shaped final growth stage, the relative width of the umbilici and the number of whorls. It is possible, however, that some species currently assigned to Salpingostoma in published literature on the basis of 
the trema alone, may be better placed in Bucania. It is equally likely that Salpingostoma represents a grade of evolution in separate lineages of Bucania, although this thesis remains to be demonstrated. All three genera are placed within the Sub-family Bucaniinae, as are Phragmolites and Offleya.

Tremanotus is a distinctive genus, notwithstanding the possible synonymy of Boiotremus. The couplet of a trema and a flared aperture has been observed in nuclei (possibly of $T$. compressus) some few millimetres in length from Gotland, placing them within Boiotremus in the sense of Horny $(1962,1963)$. On this basis alone, it is not possible to determine if the individual trema in each couplet represents a modified slit or the deepest part of a sinus. Ulrich \& Scofield (1897, pl. 67, figs 7-10) illustrated Ordovician Phragmolites fimbriata (U1rich \& Scofield, 1897; as a species of Conradella) in which repeated flared apertures are associated with an uninterrupted slit and selenizone, demonstrating that trema formation is not an inevitable consequence of apertural flaring of the type seen in Boiotremus fortis.

If Horny's model of acquisition of tremata in Tremanotus only during the late growth stages proves correct, and his sequence Tremanotus to Boiotremus can be maintained, it is probable that the tremanotinin lineage is derived from a sinuate ancestor (cf. Peel, 1972), although no obvious ancestral sinuate form has been described. If tremata are developed throughout ontogeny in Tremanotus, and Boiotremus is thus its junior synonym, then the Sub-family Tremanotinae Peel, 1972 equally well may be placed near the Bucaniinae; this step is tentatively preferred here.

\section{Systematic palaeontology}

Class Gastropoda Cuvier, 1797

Sub-class Prosobranchia Milne Edwards, 1848

Order Archaeogastropoda Thiele, 1925

Sub-order Bellerophontina Ulrich \& Scofield, 1897

Superfamily Bellerophontacea M'Coy, 1851

Family Bellerophontidae M'Coy, 1851

Sub-family Bucaniinae Ulrich \& Scofield, 1897

\section{Genus Bucania Hall, 1847}

Type species. Bellerophon sulcatinus Emmons, 1842, from the Middle Ordovician at Chazy, New York, U.S.A.

\section{Bucania squamosa (Lindström, 1884)}

Figs 7-11

1884. Bellerophon squamosus Lindström, p. 78, pl. 5, figs $17-24$

Lectotype. Here designated as Mo 26456, the specimen figured by Lindström (1884, plate 5, figs 17-19), Lower Silurian Högklint Formation at Lutterhorn (the present day Lauterhorn) on Fårö, Gotland, Sweden.

Figured material. In addition to the lectotype, from the Högklint Formation, Mo 26457, Mo 151206 (and 151207 , the other half of the same specimen) from Lauterhorn, and Mo 26494 from Lauters. From the Slite Group, Mo 26467, Mo 26496 and Mo 26731 at Lansa, Mo 26707 from Dämbar (= Dämba), Mo 151192 from Slite and Mo 26787 from Stora Myra, Martebo.

Additional material. About 20 other specimens in the collections of Naturhistoriska Riksmuseet from the same localities and horizons as the figured material.

Description. A species of Bucania Hall, 1847 somewhat removed from the morphological sphere of the type species. At least four whorls are present but the nucleus is not known. The whorl profile is slightly elliptical in earlier whorls but the dorso-lateral surface quickly becomes strongly arched such that the maximum whorl width is attained near to the abrupt transition to the flattened umbilical walls. The dorsum is anteriorly expanded in the final half whorl, resulting in the production of a sub-triangular cross-section. The umbilici are wide and open until the final growth stage, where they are partly closed by great thickening of the posterolateral lips. Whorl embracement is slight, prior to the final growth stage, and sutural indentation is deep.

The final growth stage is widely expanded, with a narrow brim. The posterior margin of the aperture extends backwards as far as the opposite wall of the umbilici. The extreme margin of the expanded outer lip is sub-circular or antero-posteriorly elongate in plan, with a pronounced median dorsal emargination anteriorly. The brim is considerably thickened.

The dorsum is sinuate. A wide sinus occupies much of the dorso-lateral surface and passes into a deep, narrow slit which generates a selenizone. In lateral view the apertural margins in the late growth stages of the lectotype tend to be lobate, with prosocyrt growth lines which curve adaperturally from the suture with the previous whorl prior to passing, often angularly, into the wide dorsal sinus. In earlier growth stages the growth 


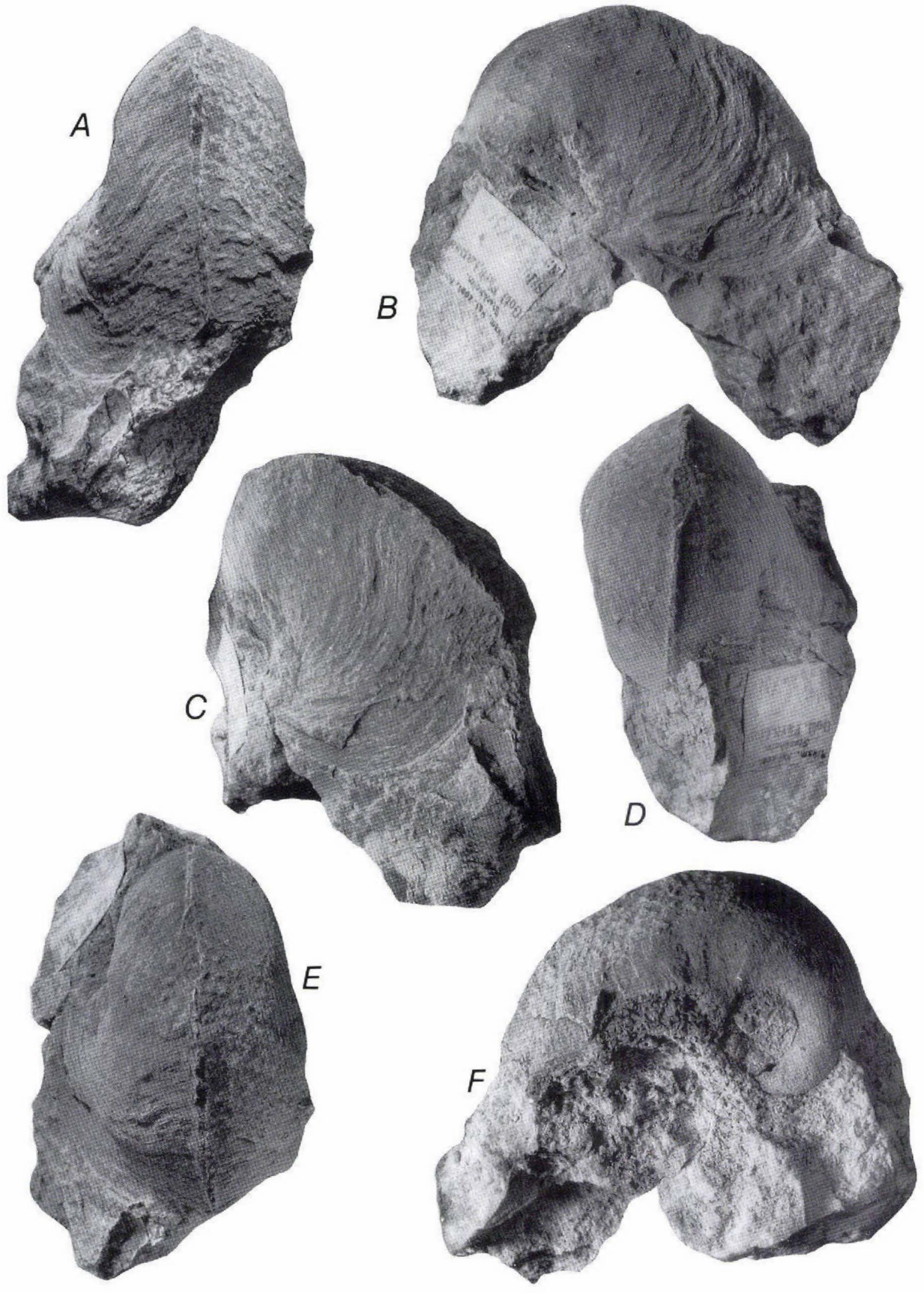


Fig. 9. Bucania squamosa (Lindström, 1884), Silurian, Gotland, Sweden. A-E, Mo 26787, Högklint Formation, Lauters, by the old harbour, $\times 1.25$. A, dorso-lateral view of immature specimen showing well-developed crenulate growth ornamentation; B, oblique postero-dorsal view; C, dorsal profile from posterior showing the irregularly broken lamellose margins to the selenizone; D, dorsal view; E, dorsal profile from the anterior to show the broad emargination passing into the slit (obscured and damaged). F, Mo 26467, Slite Group, Lansa, Fårö, detail of dorsal surface showing the form of the crenulate growth lamellae and the median dorsal crest carrying the selenizone; note lunulae at the upper right, $\times 3$.

lines slope obliquely backwards (adapically) from the suture, reflecting the tangential aperture. The sides of the inner part of the dorsal sinus are usually straight, or shallowly concave; their junction with the slit is angular, rather than a gradual increase in curvature. The selenizone is raised on a median dorsal keel with concave sides during the last half whorl. Its surface is ornamented with closely spaced, shallowly concave (adaperturally) lunulae. An open slit is absent during the final growth stage of large specimens, from a short distance prior to the greatly thickened brim. The single dorsal trema so formed is approximately one quarter of the final whorl in length.

Ornamentation consists of transverse growth lamellae with crenulated margins which often produce a pseudoreticulate pattern. In later growth stages, the lamellae often become massively rugose. The shell is thin in early growth stages, with a tendency for thickening of the umbilical walls. It becomes massively thickened in the late growth stages of large individuals, especially around the aperture. Shell structure is unknown.

Discussion. Bucania squamosa (Lindström, 1884) is morphologically quite far removed from the type species of Bucania, Bucania sulcatina from the Ordovician of New York State, as described by Ulrich \& Scofield (1897) and Knight (1941). Rather it belongs to the group of species which Ulrich \& Scofield (1897, p. 884) referred to as the section of Bucania lindsleyi (named for Bellerophon lindsleyi Safford, 1869). In this group of species the whorl profile is less strongly elliptical with a tendency to be medially inflated, the umbilici are nar-
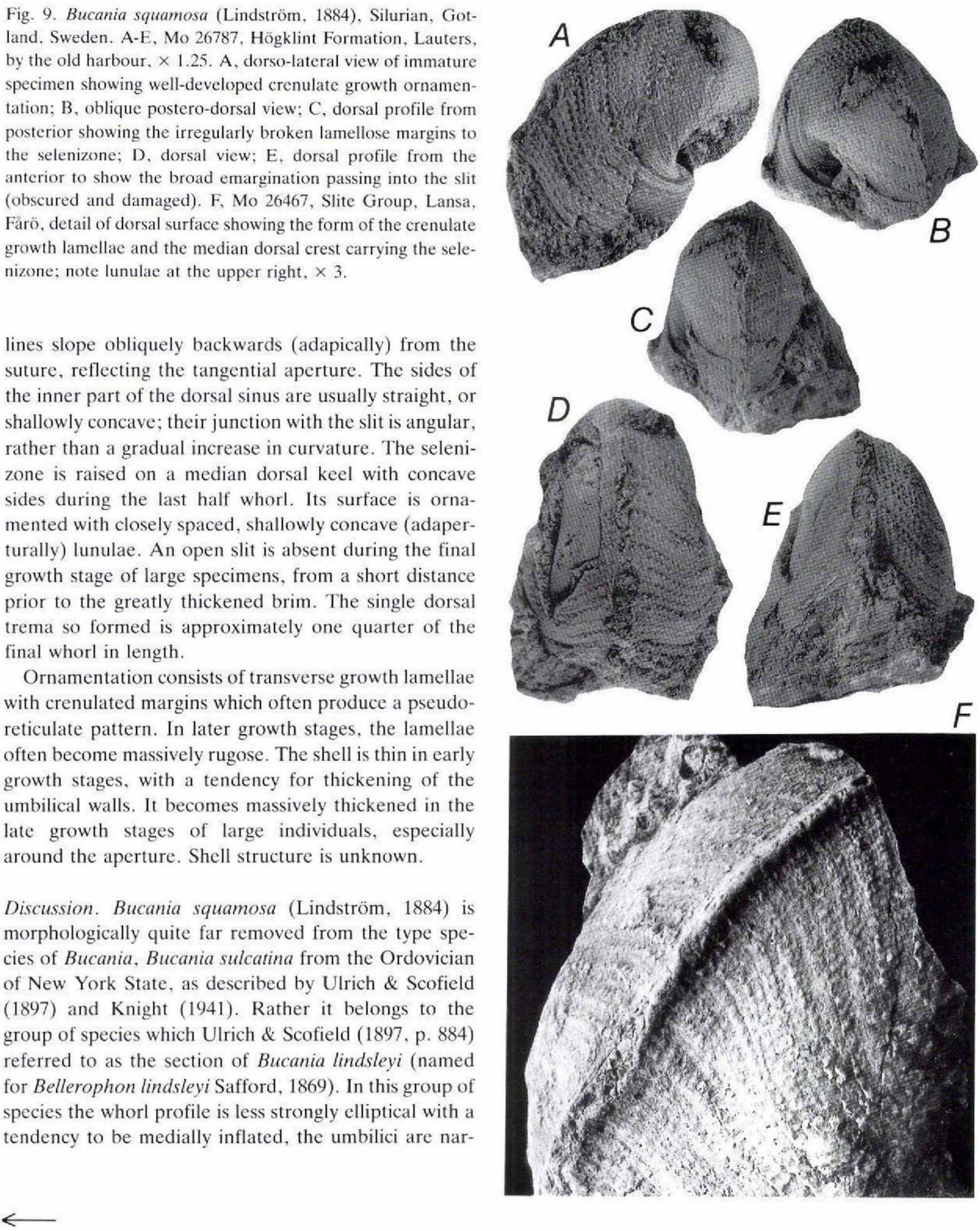

Fig. 8. Bucania squamosa (Lindström, 1884), Silurian, Slite Group, Lansa, Fårö, Gotland, Sweden. Mo 26731, × 1.5. A, dorsal profile from the anterior; note the broad emargination and the selenizone with irregular, lamellose, margins; B, lateral view with umbilicus obscured, anterior to right; $\mathrm{C}$, dorso-lateral view; $\mathrm{D}$, dorsal profile in posterior view; note the sharply elevated median dorsal selenizone; $\mathrm{E}$, dorsal plan view; note the variation in width of the selenizone due to the level of breakage through the median dorsal crest; $\mathrm{F}$, lateral view, anterior to left, showing the relative width of the umbilicus. 

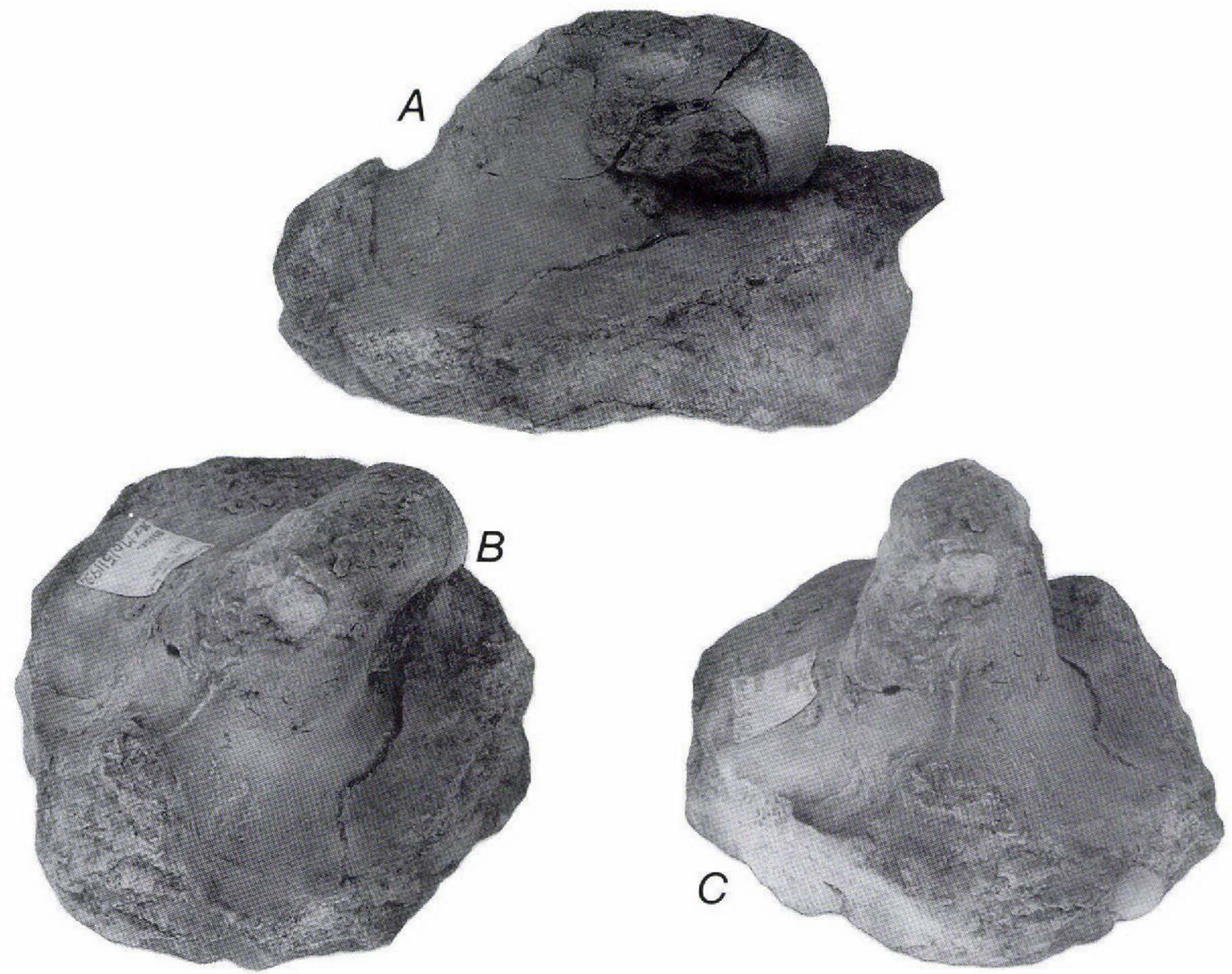

Fig. 10. Bucania squamosa (Lindström, 1884), Silurian, Slite Group, Slite, Mo 151192, internal mould slightly crushed dorsoventrally, in mudstone, $\times 1$. A, lateral view; $\mathrm{B}$, oblique dorso-lateral view showing the rounded ridge on the sediment-filled emargination indicating that the slit was not open all the way to the margin; $\mathrm{C}$, antero-dorsal view. The apparent almost planar expansion of the aperture is an impression of the enormously thickened margin of the aperture.

rower and the shell is often thicker. The aperture is also slightly expanded, a feature not characteristic of the typical group of species assigned to the genus.

The traits which caused Ulrich \& Scofield (1897) to separate an atypical group of Bucania species are clearly evident in B. squamosa. Apertural expansion is considerable and the shell is greatly thickened around this aperture. Nevertheless, the characteristic open umbilici (at least during earlier growth stages), shape of the emargination and crenulate ornamentation are typical features of Bucania.

Closure of the slit is only present in large and heavily calcified shells, such as the figured internal mould from Slite (Mo 151192; Fig. 10) where the great thickening of the apertural margins also gives a false impression of a widely expanded final growth stage. The smooth surface representing the aperture is thus a counterpart of the lower surface of the aperture. In most specimens of $B$. squamosa, however, the slit is open to the anterior margin. The situation thus parallels that in Megalomphala taenia where the slit is closed or absent anteriorly only in the largest specimens. The form of the median sinus in $B$. squamosa is retained after closure of the slit, resulting in a deep invagination in the anterior margin (Fig. 10).

The median dorsal sinus in B. squamosa is wide and passes abruptly into a narrow slit (Fig. 7E). The edges of the slit are bounded by raised lamellae, with concave lateral surfaces, which converge upwards. The lunulae are also lamellar and may fill the entire area between the bordering lamellae; alternatively the edges of the marginal lamellae may project beyond the infilled slit. The resultant raised selenizonal crest is delicate and readily broken away, producing the characteristic buca- 
Fig. 11. Bucania squamosa (Lindström, 1884), Silurian, Gotland, Sweden, camera-lucida drawings. Bar is $5 \mathrm{~mm}$ long. A, Mo 26496, Slite Group, Lansa, Fårö, cut perpendicular to the plane of the aperture (B) to show thickening of the umbilical apertural margin (s); u, umbilicus. B is shown in mirror image. $\mathrm{C}$, Mo 151206, Högklint Formation, Lauterhorn, Fårö; slightly distorted specimen shows the flattened umbilical walls and median dorsal expansion of the final whorl. D, Mo 151207 , same specimen as $C$ to show the aperture with its thickened lateral margins.
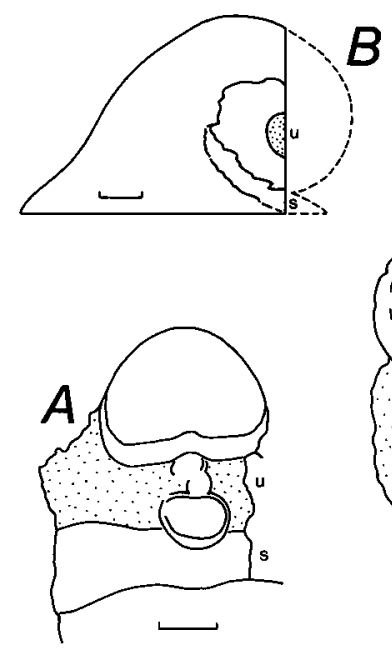

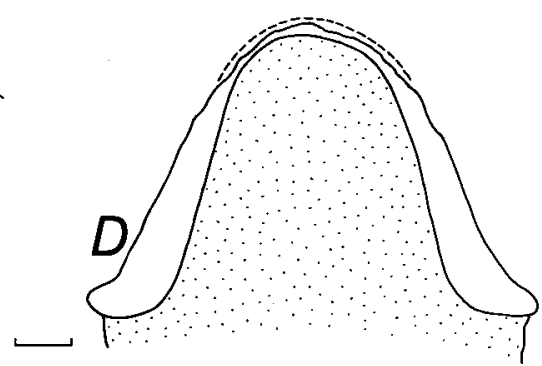

niinid selenizone with jagged margins and slightly variable width (Fig. 8).

The height of the lamellae bordering the selenizone is well seen in Mo 26787 (Fig. 7I, J), an internal mould from the Slite Group at Martebo. Here, the convergence of the lamellae is evident from the acute nature of the dorsal ridge which represents the sediment-infilled slit.

About four whorls are present in B. squamosa (Fig. 11). Early whorls tend to be transversely elliptical. The rapid expansion of the adult is manifested in median dorsal expansion and flattening of the umbilical walls to produce a trigonal cross-section.

Reed (1920-21) compared B. squamosa with Bellerophon wenlockiensis Sowerby in Murchison, 1839 but that species is probably referable to Prosoptychus Perner, 1903. The two species are superficially similar in their gross form and the slightly lobate apertural margins in $B$. squamosa can suggest the inner, deepened emargination characteristic of Prosoptychus and other cymbulariniids. In detail, however, the junction between the sinus and slit in $B$. squamosa is clearly bucaniiform and not cymbulariniform. Furthermore, the wide umbilici, low whorl impression and crenulate growth ornamentation of $B$. squamosa speak against close affinity with most cymbulariniids, where whorl impression is commonly great and the umbilici are consequently narrow.

\section{Bucania stephnae sp. nov.}

Figs 12, 13

Holotype. Mo 26732, Lower Silurian Slite Group, Samsugn in the parish of Othem, Gotland, Sweden.

Figured material. Mo 26699, paratype, same locality and horizon as holotype. Mo 26472, Högklint Formation, Kyrkberget, Gotland.

Additional material. About 30 specimens in the collections of Naturhistoriska Riksmuseet, mainly from the Högklint Formation at Kyrkberget and the Slite Group of Samsugn in Othem.

Description. A species of Bucania Hall, 1847 with about four whorls, belonging to the same morphological group as $B$. squamosa (Lindström, 1884). The whorl profile is somewhat elliptical in early growth stages, but becomes more round in the final whorl. Dorso-lateral areas are uniformly convex, increasing in curvature with lateral passage into the deep, open umbilici; umbilical width is about one fifth of the total length at maturity. Whorls embrace about the outer quarter of the previous whorl; sutural indentation is deep, in detail. The aperture is tangential to the earlier whorls; in shape it is sub-circular at the largest observed growth stage, with well developed parietal deposits. The dorsum is sinuate, its margin indicated by strongly oblique growth lines which curve back (adapically) to meet the median dorsal slit at about 70 degrees; slit about one fifth of a whorl deep. The slit generates a selenizone, the margins of which are raised to form a keel; selenizone ornamented with numerous uniformly concave lunulae, each lunulae being the surface representation of a growth lamellar which slopes abaperturally, obliquely down toward the whorl interior.

Ornamentation is of fine growth lines which may be slightly lamellose. The shell is of moderate thickness; its structure unknown. 


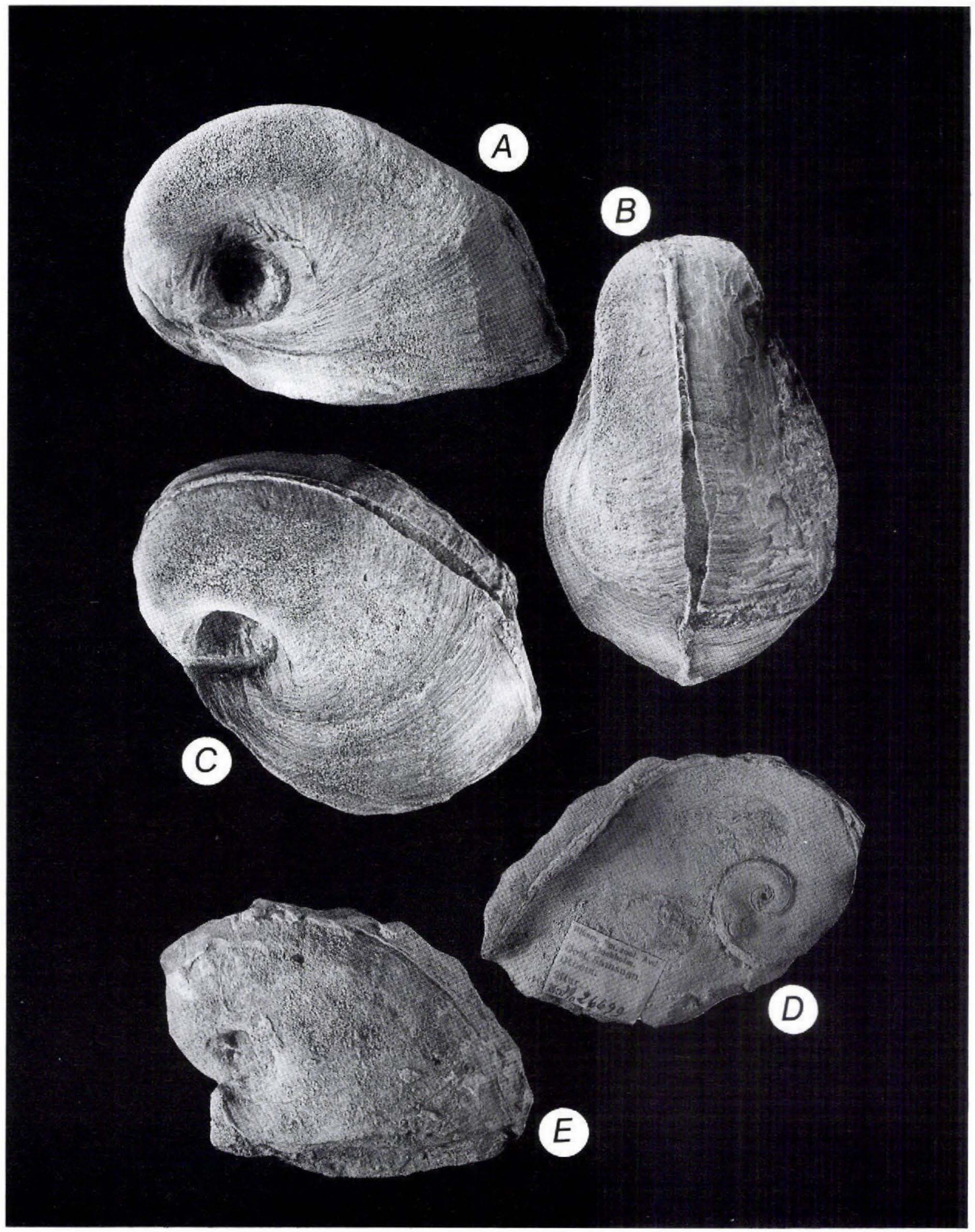

Fig. 12. Bucania stephnae sp. nov., Silurian, Slite Group, Samsugn in the parish of Othem, Gotland, Sweden. A-C, holotype, Mo $26732, \times 1.5$. A, lateral view showing the fine growth lines and umbilicus of moderate width; $\mathrm{B}$, dorsal view showing the narrow selenizone with lunulae; $\mathrm{C}$, oblique dorso-lateral view showing the uniformly curved growth lines. $\mathrm{D}, \mathrm{E}$, paratype, Mo $26699, \times 1$. The specimen has been eroded slightly oblique to the median dorsal plane of symmetry, showing the rate of expansion of the logarithmic spiral (D); note the open slit. 


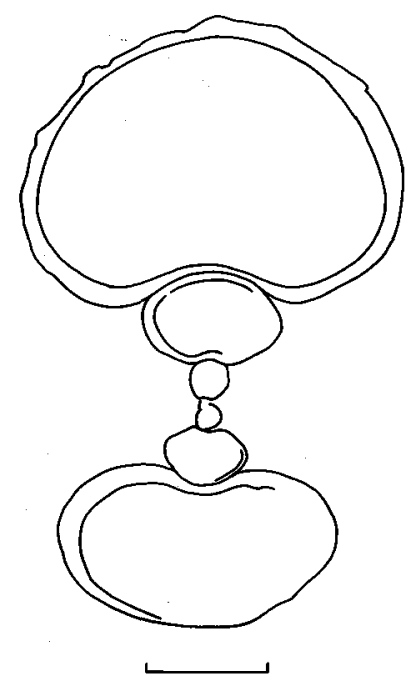

Fig. 13. Bucania stephnae sp. nov., Silurian, Högklint Formation, Kyrkberget, Gotland, Sweden, Mo 26472a. Camera-lucida drawing of transverse cross-section, scale bar is $5 \mathrm{~mm}$ long.

Discussion. Bucania stephnae is similar in profile and general form to $B$. squamosa (Lindström, 1884) and juveniles of the two species may be difficult to separate. $B$. squamosa is usually readily distinguished from $B$. stephnae by the form of its dorsal emargination. In the latter, growth lines maintain a shallowly convex form across the dorso-lateral surfaces until their passage into the slit. In B. squamosa the convex growth lines become concave toward the aperture prior to meeting the slit and selenizone at a high angle.

Ornamentation in B. stephnae typically consists only of fine growth lines or smooth lamellae, while the growth lines of $B$. squamosa are often conspicuously crenulated, often producing a near-reticulate ornamentation.

Bucania squamosa typically shows great thickening of the shell around the apertural margins, a feature absent in B. stephnae where even the adumbilical margins are thin.

The open slit is apparently preserved in Mo 26699 (Fig. 12D , E) and may also be present in the holotype (Fig. 12A-C). In the latter specimen, however, this area of the shell is slightly broken adaperturally from the preserved selenizone, although the sides of the slit seem to be compressed together in the latest fraction of the whorl (Fig. 12B). The holotype also shows slight periodicity in apertural expansion, manifested by small changes in the rate of expansion of the shell producing angular changes in the profile in lateral aspect (Fig. 12A) at about 30 degrees and 60 degrees back from the preserved aperture.
Bucania groenlandica sp. nov.

Figs 14-18

Holotype: MGUH 20.838 from GGU collection 301318 from the Washington Land Group (Early Silurian), eastern side of J. P. Koch Fjord, western Peary Land, central North Greenland (Fig. 2), collected by J. S. Peel, August 1985.

Paratypes. MGUH 20.839 and 20.840 from GGU collection 301318, MGUH 20.841 and 20.842 from GGU collection 301319. Same locality as holotype.

Description. A relatively large and laterally compressed species of Bucania Hall, 1847 with three or four whorls. The earliest whorls are not well known. During the final one and a half whorls the whorl profile has a convex, slightly vaulted dorsum passing with increased curvature onto flattened umbilical walls; lateral angulations or shoulders are not present and the greatest width of the whorl is low on the whorl profile. At the aperture, whorl width is only slightly greater than total whorl height, but width exceeds height by about one third one whorl previously. The umbilici are open and account for about one quarter of the total length. Whorl embracement is slight and sutural indentation is deep in detail.

Growth lines indicate that the aperture is tangential with growth lines sweeping backwards from the suture, adapically, towards the median dorsal slit and selenizone. At maturity the aperture maintains this tangential relationship to the previous coiled part of the shell and is slightly expanded, with a narrow brim. The dorsum is fully occupied by the broad shallow sinus, the sides of which vary from slightly convex to slightly concave, adaperturally. The sinus passes angularly into a deep median dorsal slit which forms the narrow top of a prominent keel; the keel itself has concave sides, being wider at the base than at the top. The selenizone is correspondingly narrow, but breakage of the keel produces a wide median dorsal band with jagged lateral margins and abundant lunulae. As the final growth stage is approached, immediately prior to the narrow brim, the median dorsal keel becomes less prominent and an open slit is apparently no longer present, although a narrow seam continues to the apertural margin. The slit at this stage thus forms a single trema about one sixth of the whorl circumference in depth.

Ornamentation consists of slightly lamellose growth lines crossed by spiral elements. The growth lamellae are periodically crenulated perpendicular to the growing edge. Spiral ornamentation, probably largely produced by the succession of crenulate growth lamellae, is 

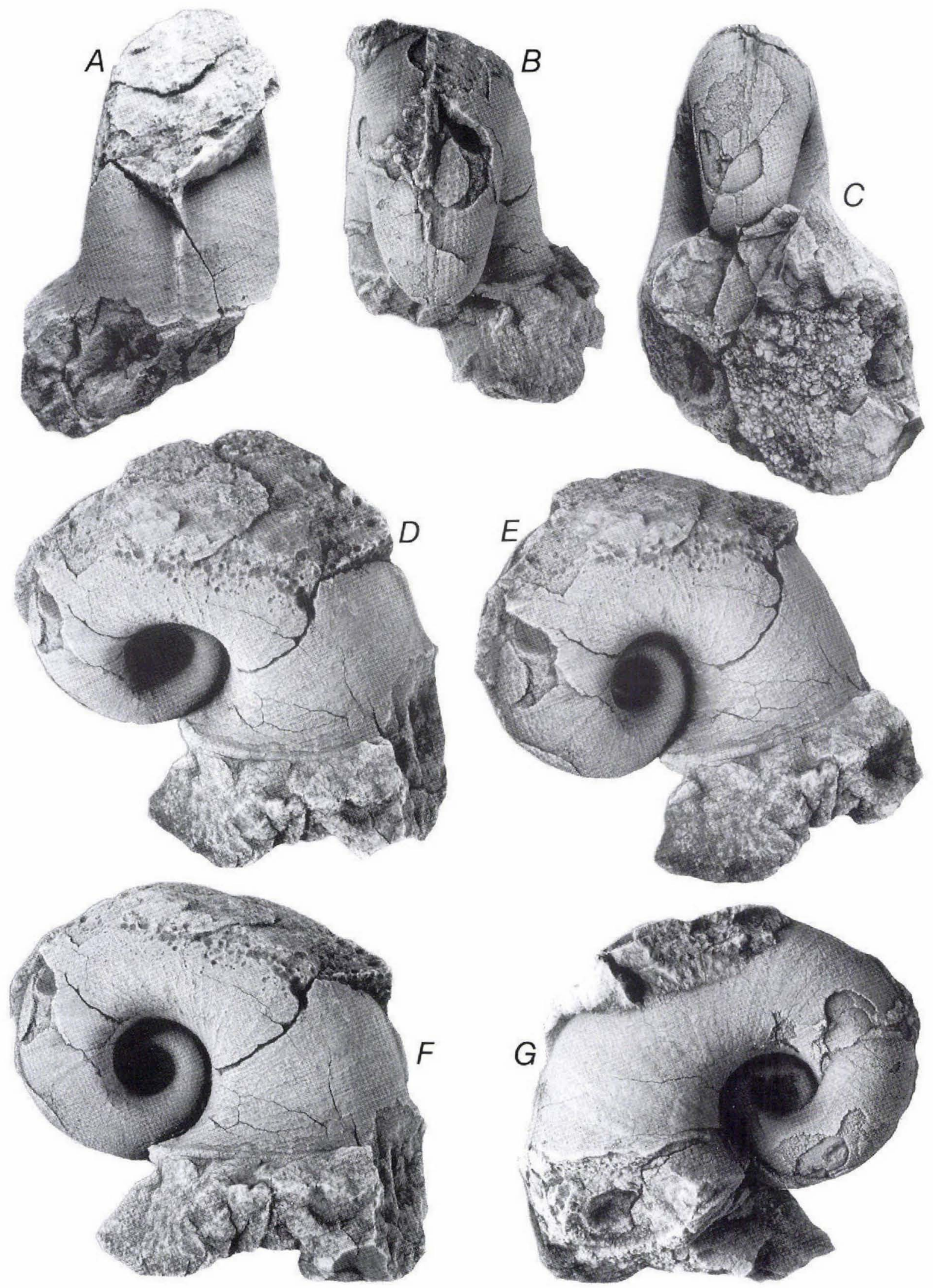
more conspicuous in earlier growth stages. The shell is thin, only slightly thickened at the apertural brim; its structure is not known.

Discussion. The type suite of Bucania groenlandica is generally well preserved in white reefal limestone, although recrystallisation has damaged the inner whorls of several specimens and inhibited the preparation of others. The holotype (Figs 14, 15) is weathered and shows pervasive recrystallisation in the median dorsal region of much of the final whorl. The aperture, however, is complete on one side and the adapical lack of an open slit can be inferred, although this feature is more readily discernible in one of the illustrated paratypes (Fig. 16).

Bucania groenlandica differs from B. squamosa in being more laterally compressed, with a more highly vaulted dorsum and with wider umbilici. This is particularly true of the final growth stage where the umbilici of $B$. squamosa become narrower on account of the massive thickening around the expanded shell aperture. $B$. groenlandica is also more laterally compressed than $B$. stephnae, with wider umbilici and lower rate of whorl expansion. B. stephnae also lacks the crenulation and spiral ornamentation of $B$. groenlandica.

Bucania groenlandica appears to be closely related to B. robusta (Whiteaves, 1904), originally described as a species of Megalomphala (see Whiteaves, 1906). It is distinguished by its crenulate and spiral ornamentation and by the more rounded flanks - Whiteaves (1906, p. 257) commented that the Canadian species was distinctly subangular around the umbilical margin. Whiteaves also commented that the umbilici in $B$, robusta are almost half the total length while his illustrations clearly indicate that their width is only one quarter of the length and therefore similar to those present in $B$. groenlandica. This discrepancy may result from measurement of the umbilici from the periphery of the whorl and not from the suture with the previous whorl, as employed here.

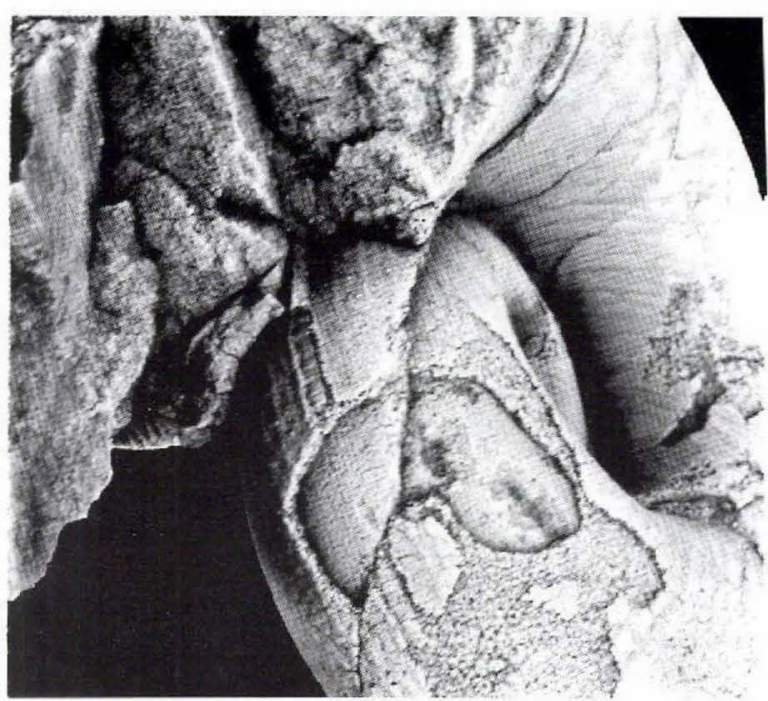

Fig. 15. Bucania groenlandica sp. nov., Silurian, Washington Land Group, eastern side of J. P. Koch Fjord, western Peary Land, central North Greenland. Holotype, MGUH 20.838 from GGU collection $301318, \times 3$. Detail of selenizone one whorl prior to the aperture (compare Fig. 14C) showing the median dorsal keel, triangular in cross-section, which carries a narrow selenizone on the narrow upper surface but which is commonly broken away to produce the characteristic bucaniiform selenizone with lunulae and jagged lateral margins.

\section{Genus Salpingostoma Roemer, 1876}

Type species. Bellerophon megalostoma Eichwald, 1840 from the Ordovician of Estonia.

Diagnosis. Bucaniiform bellerophontaceans with three or four whorls which are generally characterised by the acquisition of a bell-shaped final growth stage, during which much of the deep, narrow slit is absent. The umbilici are open and widely phaneromphalous. The aperture is commonly widely expanded with explanate margins.

Ornamentation is principally of transverse growth lines which may be lamellose, with crenulations perpendicular to the growing margin; the crenulations may produce a crude spiral ornamentation.

Fig. 14. Bucania groenlandica sp. nov., Silurian, Washington Land Group, east side of J. P. Koch Fjord, western Peary Land, central North Greenland. Holotype, MGUH 20.838 from GGU collection $301318, \times 1.5$. Note the pitted and weathered median dorsal area. A, anterior view; B, posterior view showing the spiral ornamentation which is only weakly developed half a whorl later (A); C, apertural view, with the imperfectly preserved and sediment filled aperture below; D, E, oblique lateral views to show the form of the apertural margin; F, G, lateral views showing the open umbilici (the early whorls in $G$ are distorted diagenetically). 


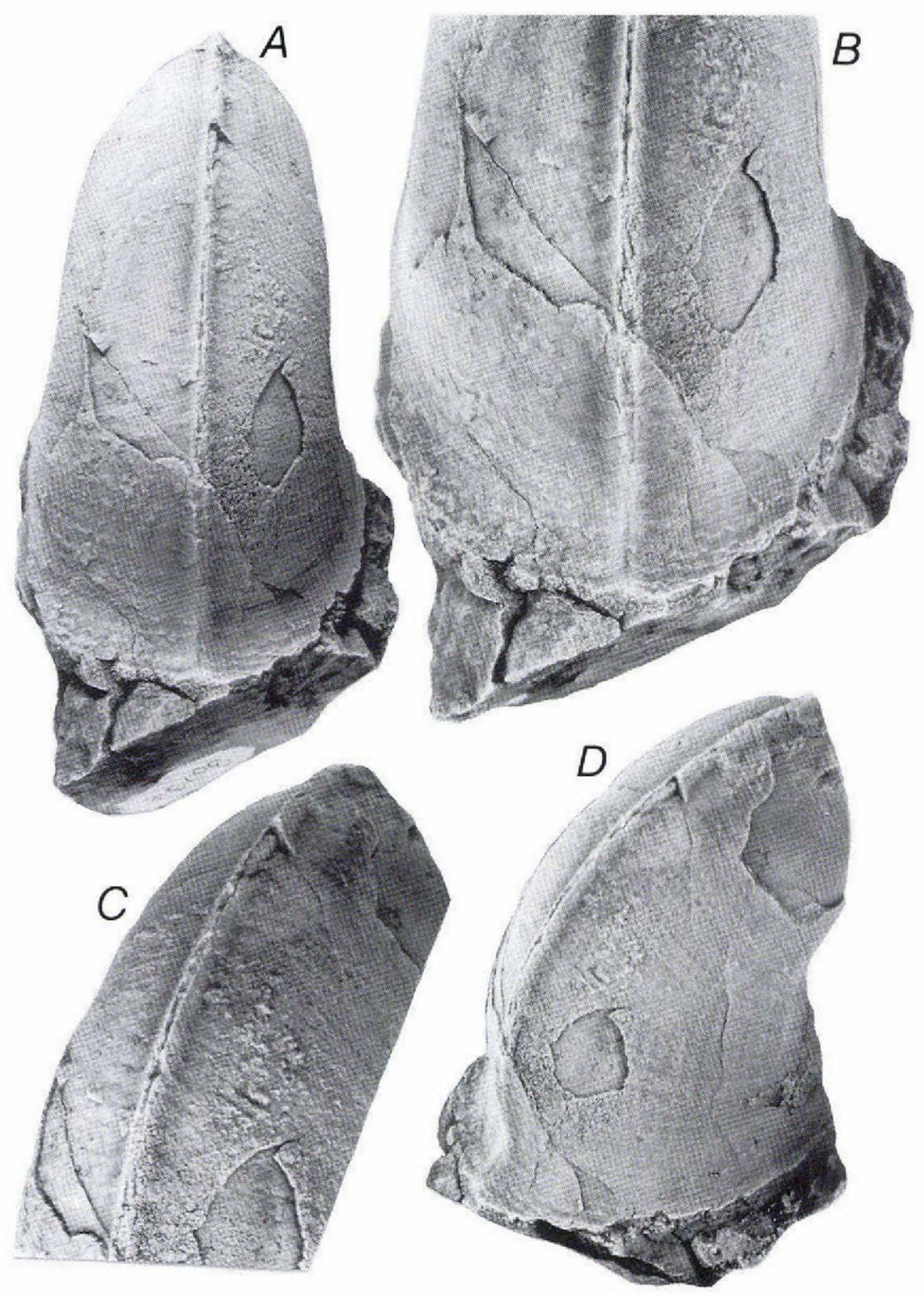

Fig. 16. Bucania groenlandica sp. nov., Silurian, Washington Land Group, eastern side of J. P. Koch Fjord, western Peary Land, central North Greenland. Paratype, MGUH 20.839 from GGU collection 301318. Apertural fragment showing the narrow slit forming the upper surface of the triangular (in cross-section) median dorsal keel. At the earliest preserved growth stage (top in $\mathrm{A}$ and D) the slit is closed to form a selenizone. At the latest growth stage (bottom in A, B, D) the open slit is replaced by a narrow seam (B), such that the slit does not penetrate the slightly expanded apertural margin. $\mathrm{A}$, antero-dorsal view, $\times 1.5 ; \mathrm{B}$, detail of same showing the slit replaced by the seam, anteriorly, $\times 2.1 ; \mathrm{C}$, oblique dorsal view showing fine growth lines curving backwards (adapically) as they cross the sides of the median keel towards the open slit, $\times 2.1 ; \mathrm{D}$, oblique antero-dorsal view showing the slightly expanded apertural margin, $\times 1.5$.

\section{Salpingostoma megalostoma} (Eichwald, 1840)

Figs 19-22

1840. Bellerophon megalostoma Eichwald, p. 111.

1859. Bellerophon megalostoma; Eichwald, pl. 41, fig. 5 .

1860. Bellerophon megalostoma; Eichwald, p. 1069.

1876. Salpingostoma megalostoma; Roemer, pl. 5.

1925. Salpingostoma megalostoma; Koken \& Perner, pp. 32-33, pl. 19, figs $6,17,18$.

1941. Salpingostoma megalostoma; Knight, pp. 305306 , pl. 14, figs $2 \mathrm{a}-\mathrm{c}$.
Type material. A fragmentary internal mould carrying the number $1 / 2310+1 / 2311$ in the collections of the Chair of Historical Geology, University of Leningrad. Only the aperture is preserved.

Additional figured material. Mo 70629, Mo 70637 and Mo 151187, Ordovician, Osmussaar (= Odinsholm), Estonia.

Description. The type species of Salpingostoma Roemer, 1876 with about 4 whorls and widely phaneromphalous umbilici. The nucleus is unknown; early whorls are elliptical in cross-section but, during the last 
Fig. 17. Bucania groenlandica sp. nov., Silurian, Washington Land Group, eastern side of J. P. Koch Fjord, western Peary Land, central North Greenland. Paratype, MGUH 20.841 from GGU collection 301319 , $\times 1.5$. Note the periodic crenulation of growth lamellae. A, lateral view; $\mathrm{B}, \mathrm{C}$, posterior views showing the median dorsal keel which is broken away below to produce a wide selenizone with lunulae and jagged lateral margins; D, oblique postero-lateral view showing the course of the lamellose growth lines on the umbilical wall.

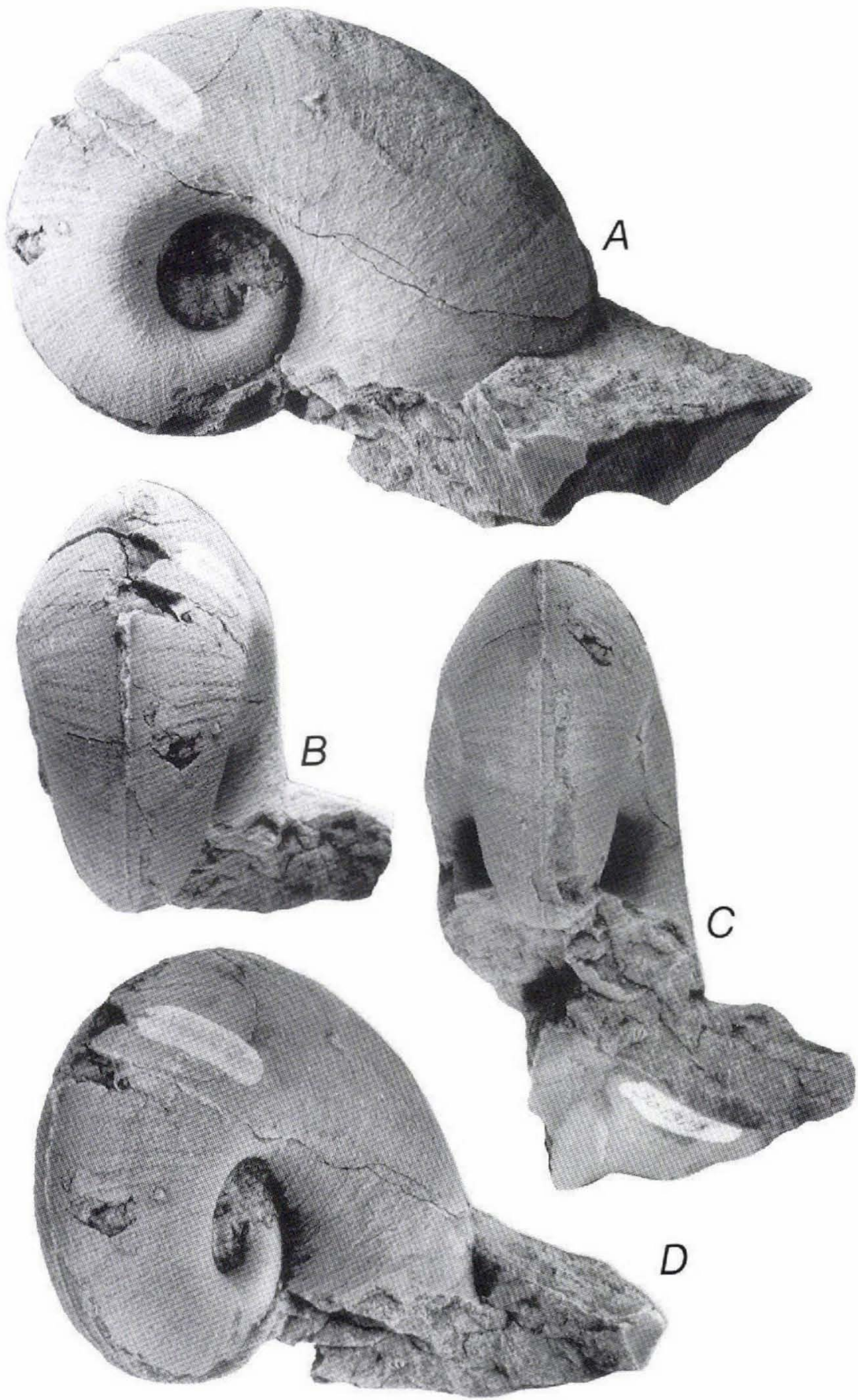

half whorl, the dorsal surface becomes strongly arched medially such that the cross-section is sub-triangular. Whorl embracement is slight but sutures are deep in detail. In the final growth stage, the shell expands abruptly and acquires a widely expanded aperture with explanate margins. In plan view this aperture is slightly longer than wide; it extends well to the presumed posterior of the earlier coiled portion of the shell which is elevated above the plane of the aperture, in a bellshaped form.

The aperture is sinuate, with a shallow, but wide, emargination passing abruptly into a deep slit. In the 

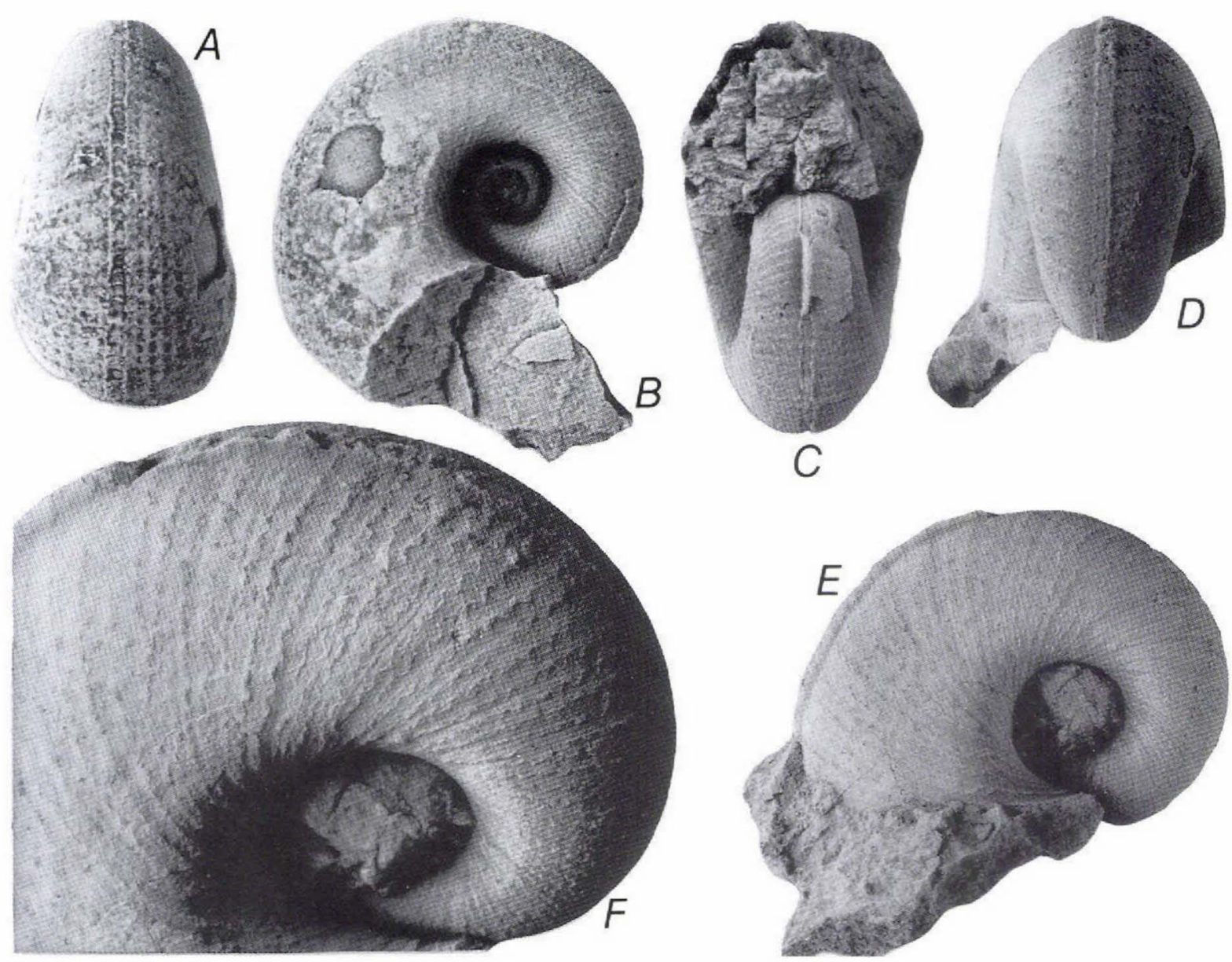

Fig. 18. Bucania groenlandica sp. nov., Silurian, Washington Land, eastern side of J. P. Koch Fjord, western Peary Land, central North Greenland. A-C, paratype, MGUH 20.840 from GGU collection 301318, early whorls showing pronounced spiral ornamentation and selenizone with jagged lateral margins resulting from removal by breakage of the keel, $\times 2.5$. A, dorsal view; $\mathrm{B}$, lateral view; $\mathrm{C}$, apertural view showing a fragment of the median dorsal keel remaining, in association with a small patch of recrystallised shell from the subsequent whorl (broken away). D-F, paratype, MGUH 20.842 from GGU collection 301319 , showing the periodic crenulation of growth lamellae separated by linear growth lines. D, posterior view, with the median dorsal keel broken away, $\times 1.5 ; \mathrm{E}$, lateral view showing the median dorsal keel preserved in the latest quarter of a whorl (left), $\times 1.5 ; \mathrm{F}$, detail of ornamentation, $\times 3$.

final growth stage, however, an open slit is absent from the final one quarter of a whorl, leaving a single trema on the top of the shell when it is oriented in life position with the aperture facing downward. The slit seems to have been closed, prior to the explanate aperture, but no slit penetrated to the anterior margin of the flared aperture itself. The slit generates a selenizone bounded by spiral threads and with a concave upper surface. The selenizone is ornamented by adaperturally concave lunulae.

The shell is ornamented by transverse growth lines; shallow crenulation of successive apertural margins produces a discontinuous, wavy spiral pattern. The shell is thin but in adults it is thickened at the umbilical wall and around the transition to the explanate stage of the expanded aperture; its structure is not known.

Discussion. Knight (1941) redescribed this species on the basis of the original descriptions and figures of Eichwald $(1840,1859,1860)$. He reproduced Eichwald's figures which are greatly stylised and show no indication of a slit nor a selenizone on the dorsum.

Koken \& Perner (1925) described 14 species of Salpingostoma from the Baltic Ordovician, many of which clearly show a long, open slit which is closed or absent near to the presumed anterior margin. Five of these 


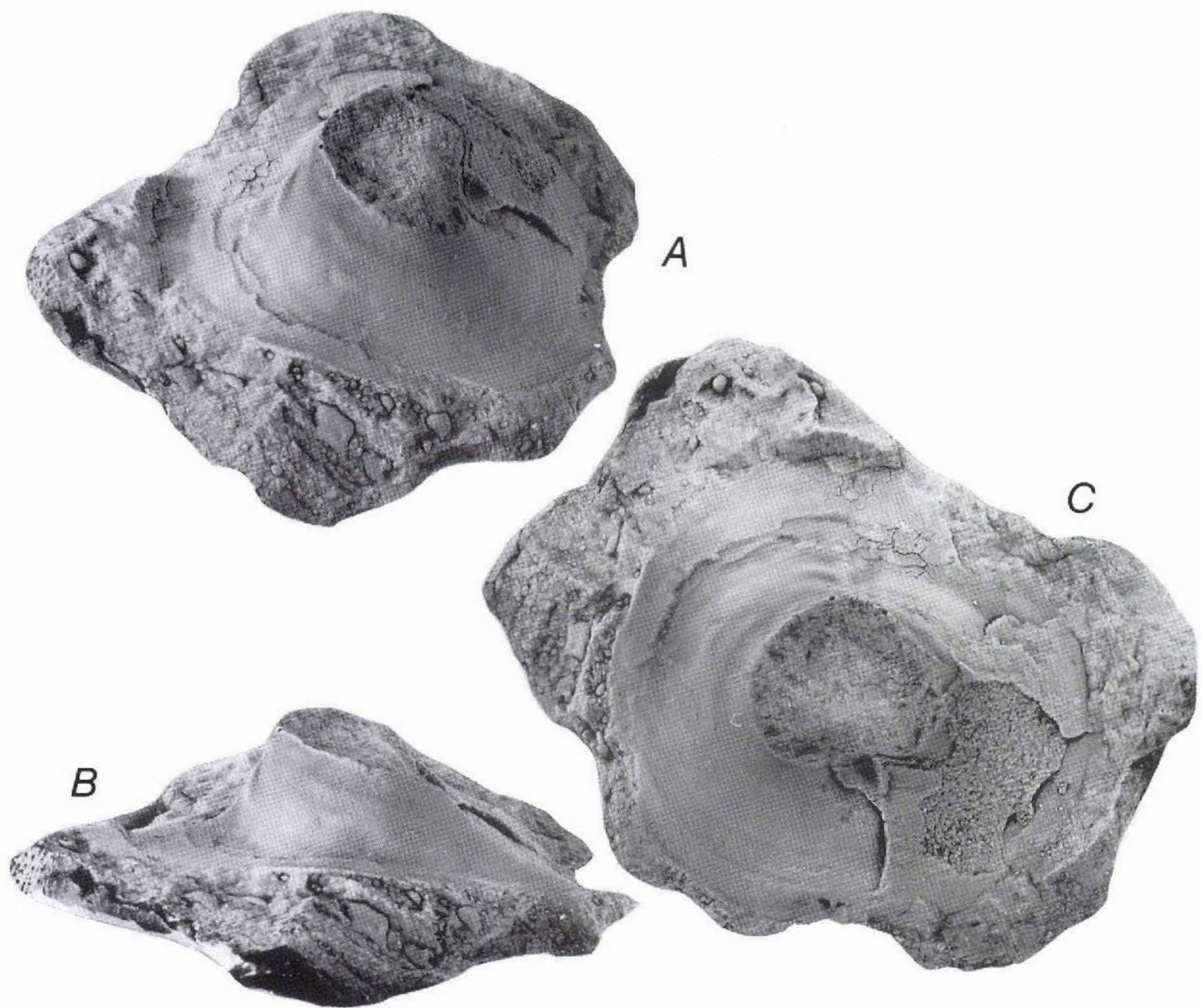

Fig. 19. Salpingostoma megalostoma (Eichwald, 1840), plaster cast of the holotype of the type species of Salpingostoma Roemer, 1876, carrying numbers $1 / 2310$ and $1 / 2311$ in the collection of the Chair of Historical Geology, Leningrad, U.S.S.R., $\times 2$. The specimen is an almost completely exfoliated internal mould preserving only the expanded aperture which forms the latest growth stage; traces of fine growth lines are visible on the umbilical wall (lower surface in C). A, oblique lateral view; B, lateral view, with anterior to the left; the aperture in dorsal plan view. Plaster cast made by Ellis L. Yochelson, palaeobiological collections of the U.S. National Museum of Natural History.

Ordovician species, $S$. crassa, S. granulosa, S. compressa, $S$. roemeri and $S$. elevata, all attributed in the text to Koken, closely resemble $S$. megalostoma, as figured by Koken \& Perner (1925), and may prove to be synonymous.

A plaster cast made by Dr. Ellis L. Yochelson of a specimen in the University of Leningrad, U.S.S.R., supposedly comprising the type material of $S$. megalostoma, is figured here (Fig. 19), although Knight (1941) claimed to have six poor plaster casts of the type lot. Only the aperture is preserved, providing little information for a description of the species or genus. However, the collections of the Paleozoological Department, Naturhistoriska Riksmuseet, Stockholm, contain several specimens from Osmussaar, Estonia, collected and identified by Gustav Holm a hundred years ago which appear to be topotypes of $S$. megalostoma. These specimens form the basis of the present re-description of Salpingostoma.

The most complete of the 4 specimens figured here (Mo 151187) clearly shows the explanate form of the expanded aperture characteristic of the final growth stage and the elevation of the earlier whorls above the aperture (Fig. 20). In most other Ordovician species of 

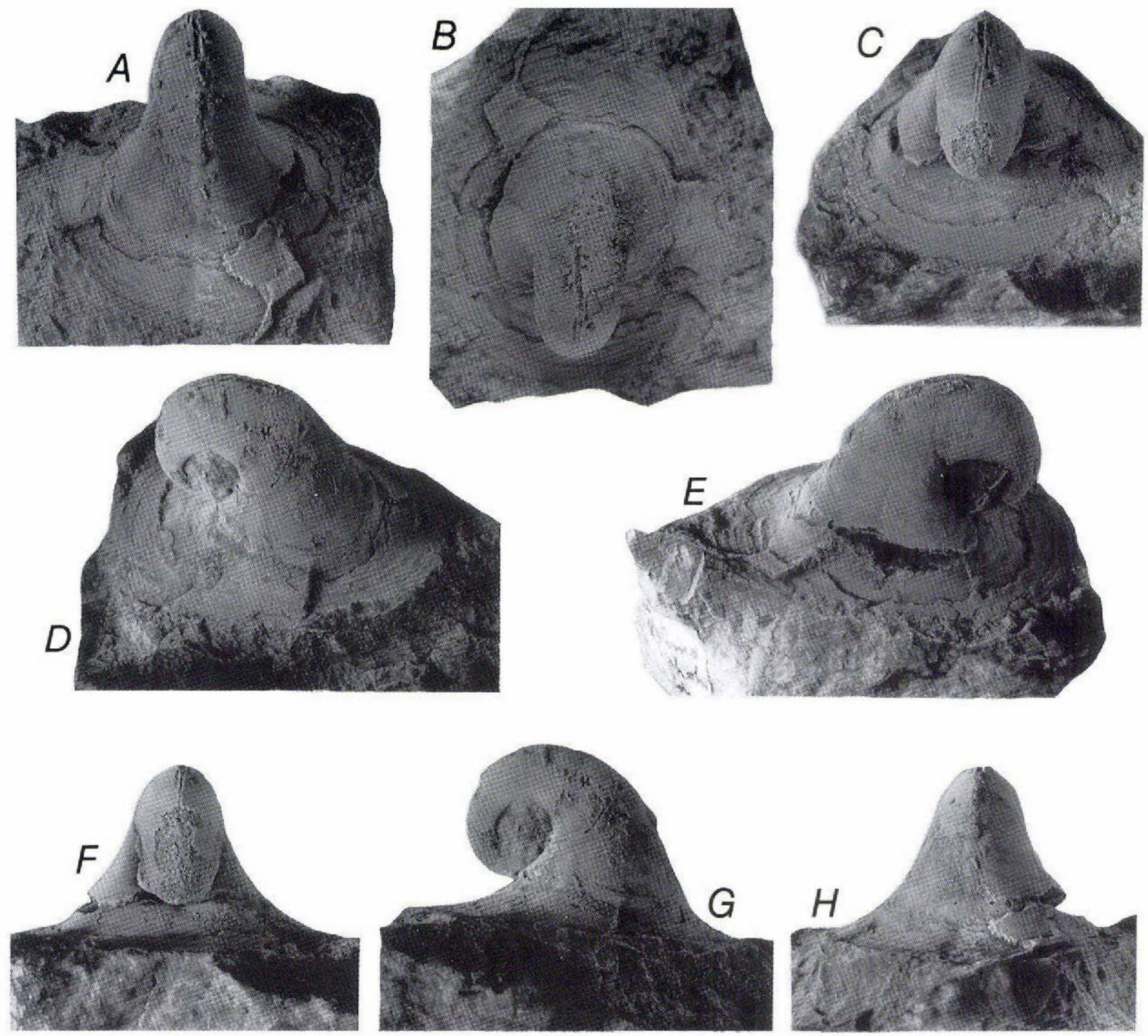

Fig. 20. Salpingostoma megalostoma (Eichwald, 1840) from the Ordovician $\left(\mathrm{C}_{\mathrm{I}} \mathrm{b}\right.$ or $\mathrm{C}_{\mathrm{I}} \mathrm{c}$ ) of Osmussaar (Odinsholm), Estonia. Mo 151187 , collected by $\mathrm{G}$. Holm, $1883, \times 1.5$. A, antero-dorsal view showing the narrow early part of the final whorl with a pronounced median slit giving way to the widely expanded, explanate, final growth stage without a slit; B, dorsal plan view, with anterior upwards, note the small sinus in the anterior margin; C, postero-dorsal view showing the narrow selenizone, and entire posterior margin to the explanate aperture; D, E, oblique lateral views; F, dorsal profile in posterior view; $G$, lateral profile; $H$, dorsal profile in anterior view.

Salpingostoma, the elevation of the early whorls above the expanded aperture is much less well developed than in $S$. megalostoma.

A third specimen (Mo 70629) is an internal mould lacking the apertural margins (Fig. 21). The umbilici appear wider than in Mo 151187 , but this is obviously due to the lack of shell.

The Leningrad specimen (Fig. 19) differs from Mo 151187 (Fig. 20) in showing an equidimensional apertural plan which is less widely expanded, although this may be simply an ontogenetic feature. A similar growth stage is seen in the specimen which was sectioned to show the inner whorls (Mo 70637a, b; Fig. 22).

In form, $S$. megalostoma thus resembles Grandostoma Horny, 1962, from the Ordovician of Czechoslovakia, from which it is distinguished by the absence in Horny's genus of a slit and subsequent selenizone.

Bellerophacmaea Horny, 1989, from the Upper Silurian of Czechoslovakia, has a proportionately much larger apertural area and the early whorls are conse- 


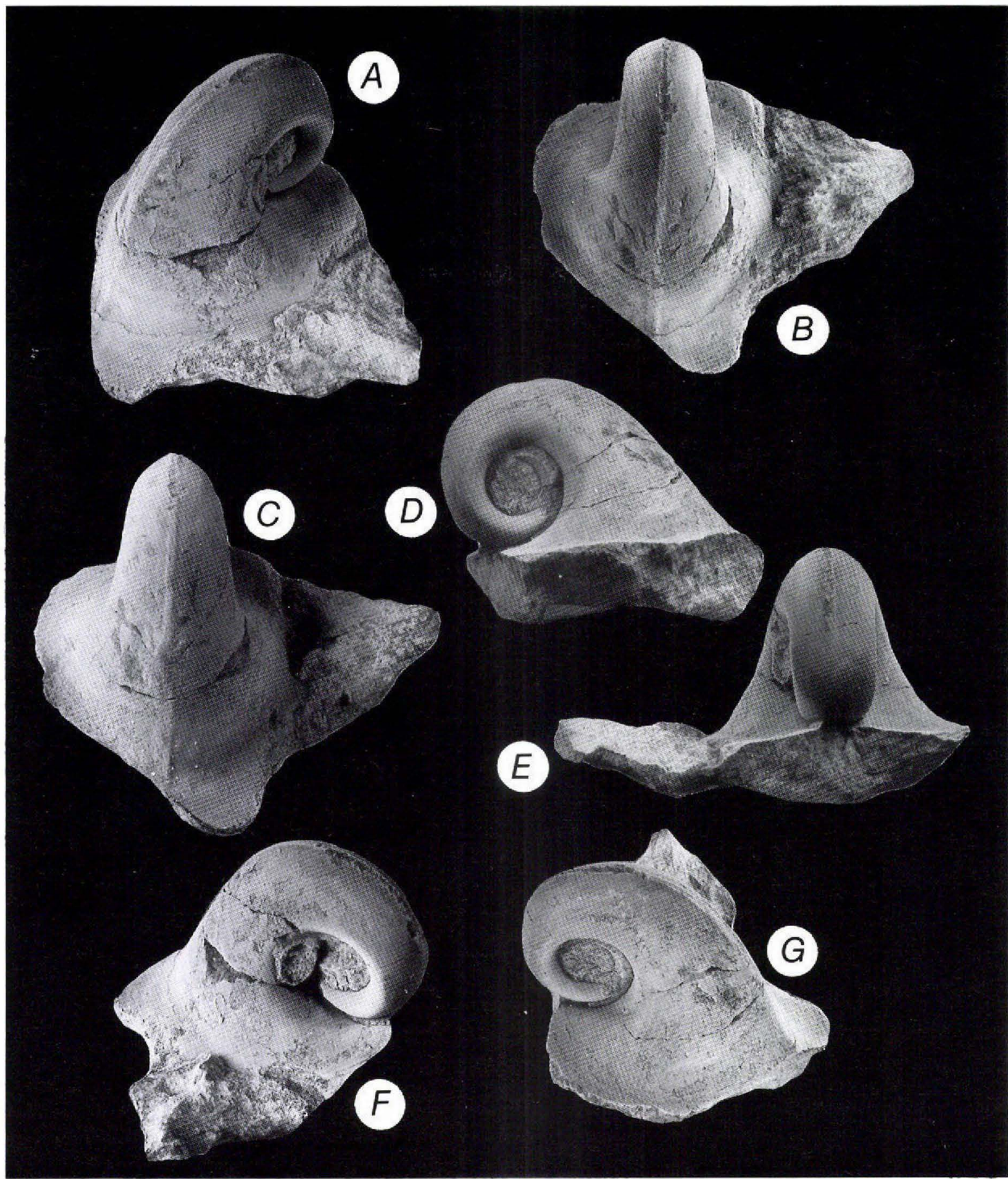

Fig. 21. Salpingostoma megalostoma (Eichwald, 1840), an internal mould from the Ordovician of Osmussaar (Odinsholm), Estonia. Mo 70629, $\times 1.5$. Note the smooth-topped median dorsal band in the final growth stages indicating closure or absence of a slit; the rough groove immediately preceeding this band corresponds to the open slit. Due to the absence of shell, the specimen appears to have unusually wide umbilici. A, oblique dorso-lateral view; B, dorsal plan view showing the broken apertural margins; $\mathrm{C}$, antero-dorsal view; D, lateral view, anterior to the right; E, dorsal profile in posterior view; F, G, dorso-lateral views 


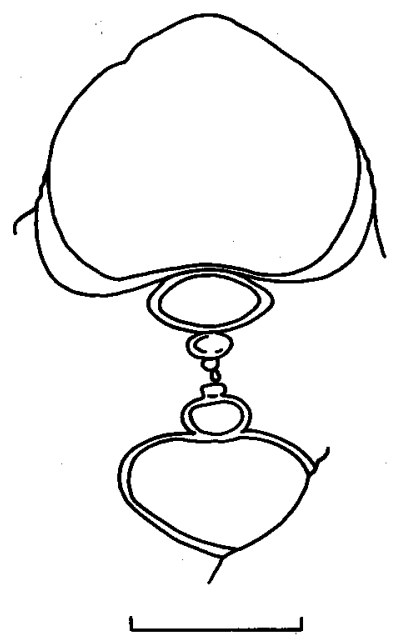

Fig. 22. Salpingostoma megalostoma (Eichwald, 1840), Ordovician, Osmussaar (Odinsholm), Estonia. Camera-lucida drawing of transverse cross-section to show the open umbilici and three or four whorls. Note the thickening of the umbilical walls at the latest growth stage which is only about one sixth of a whorl prior to the explanate aperture. Mo 70637a, b. Scale bar is $5 \mathrm{~mm}$.

quently much reduced. A slit generating a short selenizone is present in these early stages, which carry a prominent reticulate ornamentation, but this is gradually replaced by a shallow sinus in the widely expanded apertural area.

\section{Salpingostoma martinssoni sp. nov.} Fig. 23

Derivation of name. In memory of Anders Martinsson, Uppsala, in token of his contribution to Gotland geology.

Holotype. Mo 27007 from the Lower Silurian Visby Formation, Visbyhamn, Gotland.

Additional material. Mo 151193, Mo 151194 from the Visby Formation at Visby, Gotland.

Description. A species of Salpingostoma Roemer, 1876, apparently with three or four whorls. The whorl profile is poorly known, but the shallowly arched dorsum is seen to expand medially during the last half whorl prior to the rapid expansion characteristic of the final growth stage. The umbilici are open and of moderate width. Whorl embracement is moderate; the degree of sutural indentation is not known. The apertural margins are widely expanded, explanate, in the final growth stage; the anterior and lateral margins are reflexed, while the posterior margin extends beyond the earlier coiled portion of the shell. The extreme margin of the explanate growth stage is sub-circular, or slightly elongated antero-posteriorly, in apertural view.

The dorsum has a median slit which is absent from the last sixth of the final whorl to leave a single, elongate, trema. The length of the trema is about one twelfth of the circumference of the final whorl. The selenizone is narrow, and raised on the final whorl. The presumed anterior margin of the explanate aperture has a deep, narrow sinus which becomes progressively effaced towards the margin. The posterior margin has a shallow, median emargination.

Ornamentation is imperfectly known; the undersurface of the explanate aperture has fine transverse growth lines. The original shell thickness and structure are not known.

Discussion. Available material of Salpingostoma martinssoni is from mudstone, and is crushed to a greater or lesser extent. Details of whorls prior to the final whorl are consequently obscure, but the bell-shaped aperture with widely explanate margins, and the absence of the slit over the last sixth of a whorl are characteristic features of Salpingostoma.

$S$. martinssoni is larger than the type species, S. megalostoma, and has a more widely expanded, explanate, final growth stage. The earlier, coiled portion of the shell in the latter species is more strongly elevated above the plane of the aperture than in $S$. martinssoni.

Salpingostoma orientale Twenhofel, 1928 from the Jupiter and Chicotte Formations (Early Silurian) of Anticosti Island, Canada, differs from $S$. martinssoni in the reported presence of strong spiral ornamentation. $S$. boreale Whiteaves, 1904 from the Upper Llandovery Ekwan River Limestone of the Hudson Bay Lowlands, Ontario, Canada, and possibly from the Washington Land Group of Hall Land, western North Greenland, is a diminutive species with a sub-circular whorl profile. The trema is poorly known but must be much smaller than that present in $S$. martinssoni.

$S$. inornata Northrop, 1939 from the Silurian of the Gaspé Peninsula, Quebec, Canada, is too poorly preserved for determination or comparison (Peel, 1972).

\section{Genus Megalomphala Ulrich in Ulrich \& Scofield, 1897}

Type species. Bellerophon contortus Eichwald, 1860 from the Ordovician of Estonia. 
Fig. 23. Salpingostoma martinssoni sp. nov., Lower Silurian, Visby Formation, Visbyhamn, Gotland, Sweden. Holotype, Mo 27007, × 1.2. The specimen, which is partly crushed in shale, is shown in apertural view (right; anterior upwards); the median dorsal area (left) preserves the selenizone. Note the absence of slit or selenizone from the anterior margin, where only a shallow sinus persists.

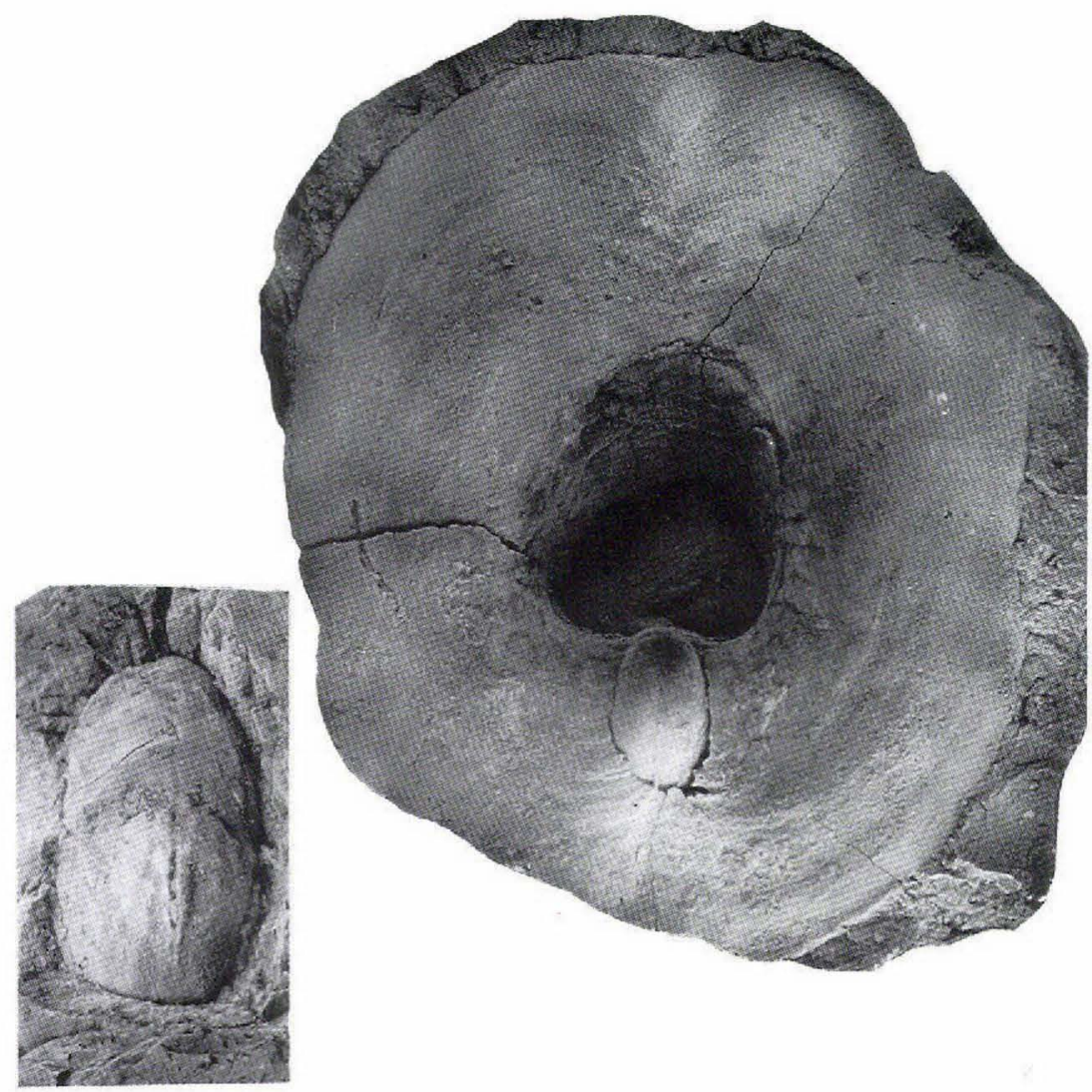

Diagnosis. Essentially bucaniiform bellerophontaceans with a lenticular or reniform whorl profile, tangential aperture producing strongly oblique growth lines, and a deep, narrow slit. The rate of whorl expansion is low and the number of whorls is high (6), producing a narrow shell with very wide, open, umbilici. The mature shell aperture is slightly expanded, with the final fraction of the anterior margin lacking an open slit. Ornamentation consists of transverse growth lines.

Discussion. Species referred to Megalomphala can usually be distinguished from Bucania Hall, 1847 by having more whorls, a lower rate of whorl expansion, wider umbilici and a lack of crenulate or spiral ornamentation. The umbilici in Megalomphala may be as wide as half the total length of the shell, almost twice the ratio that is characteristic of Bucania. The rate of whorl expansion in Megalomphala, measured as the ratio of the width of the whorl to the width of the previous whorl (see Peel, 1974, fig. 2), is normally about 2 in Megalomphala, but often exceeds 3 in Bucania.

Fewer whorls are present in Salpingostoma Roemer, 1876 than in Megalomphala and the final growth stage is often strongly expanded and bell-shaped in the former genus. The slit in Salpingostoma is often absent from much of this final growth stage and an explanate aperture is frequently developed.

Megalomphala is distinguished from Modestospira, from the Lower Ordovician of Bornholm, Denmark (Fig. 1) and Poland by its true slit and selenizone; only a median dorsal sinus is present in Modestospira. The Lower Ordovician Peelerophon Yochelson in Babin et al., 1982, closely resembles Modestospira (see Yochelson in Babin et al., 1982 and Fryda, 1988) but is characterised by a median dorsal slit and selenizone, and prominent lamellose growth ornamentation; the latter serve to distinguish it from Megalomphala. Peelerophon also differs from Megalomphala in having more laterally compressed whorls, lacking lateral angulations.

Yochelson in Babin et al. (1982) tentatively referred a single internal mould from the Lower Ordovician of France to Megalomphala. He described muscle scars on the dorsal surface, although reproduction of the original photographs is too poor to evaluate these. Nevertheless, as Yochelson points out, the muscle scars in the French material are quite different from the scars on the umbilical wall in Megalomphala taenia (Fig. 25) described by Peel (1976), suggesting that two quite distinct taxa are involved. 
Megalomphala contorta (Eichwald, 1860) Fig. 24

1860. Bellerophon contortus Eichwald, p. 1072, pl. 41 , fig. 3.

1897. Megalomphala contorta; Ulrich in Ulrich \& Scofield, 1897, p. 850.

1925. Megalomphala contorta; Koken \& Perner, p. 67 , pl. 25 , figs $4,5,11$.

1941. Megalomphala contorta; Knight, p. 192, pl. 8, figs $1 \mathrm{a}, \mathrm{b}$.

Holotype. The specimen figured here as Fig. 24A-D, number 308 in the Eichwald collection of the Chair of Historical Geology, University of Leningrad, an internal mould with traces of shell in the umbilicus on the right side (Fig. 24C), from the island of Hiiumaa (= Dagö), Estonia (Fig. 3).

Description. Type species of Megalomphala Ulrich in Ulrich \& Scofield, 1897 with about six whorls. Early whorls poorly known, but strongly lenticular in crosssection with acute peripheral angulations separating the dorsal surface from the umbilical surfaces. Later whorls with more rounded peripheral angulations and a tendency to be slightly more inflated dorsally. At the latest preserved growth stage, the width of the whorl is more than twice its internal height and the peripheral angulations are at mid-whorl. In cross-section the dorsal areas are flattened, sloping adaxially away from the median dorsal area toward the peripheral angulations. The umbilical walls are also flattened, sloping adaxially in towards the suture with the previous whorl; sutural indentation is deep. Umbilici widely phaneromphalous, almost half of the total length.

Growth lines indicate that the aperture was tangential, sloping obliquely back (adapically) from the suture with the previous whorl towards the median dorsal area. Growth lines on the dorsal surface are adaperturally shallowly convex and pass abruptly into a narrow slit carried on a low median dorsal crest.

Shell ornamentation seemingly only of growth lines which are seen to be closely spaced on the umbilical walls. Shell thickness not known, except on the umbilical wall of the final preserved whorl where it is moderately thick. Shell structure is not known.

Discussion. The description is based on photographs and plaster casts of the holotype (Fig. 24). The aperture is broken and it is not known if Megalomphala contorta develops a bell-shaped final growth stage. Similarly, the slit and selenizone are not preserved although their presence is confidently expected from the shape of the growth lines as they approach the median dorsal crest.

\section{Megalomphala taenia (Lindström, 1884)} Figs 25-28

1884. Bellerophon taenia Lindström, p. 76, Pl. 6, figs 22-25; Pl. 7, figs 4, 5.

1897. Megalomphala taenia, Ulrich in Ulrich \& Scofield, p. 850.

1976. Megalomphala taenia; Peel, pp. 51-54, fig. 2A-H.

Lectotype. Here designated as MMH 13.037, the specimen figured by Lindström (1884) as Pl. 7, figs 4, 5, re-illustrated by Peel (1976, fig. 2A-C, H). The lectotype was collected from the Upper Silurian Hemse Group at Östergarn, Gotland, Sweden.

Figured material. In addition to the lectotype, USNM 188177, Mo 26559, Mo 26560, Mo 26639, Mo 151201, Mo 151202 and Mo 151190, from Östergarn. Mo 26639 from Grogarn (Östergarn). All specimens from the Hemse Group.

Additional material. About 40 specimens in the collections of Naturhistoriska Riksmuseet mainly from the Hemse Group at Östergarn.

Description. A species of Megalomphala Ulrich in Ulrich \& Scofield, 1897 with about six whorls in which the whorl cross-section is transversely elliptical. The height of the whorl cross-section is about half of its width; maximum whorl width is at just above mid-whorl height. The dorsum is shallowly convex and passes by way of acutely convex dorso-lateral shoulders into the widely phaneromphalous umbilici. The umbilical walls are flattened below the periphery, sloping in toward the umbilici, but increase in convexity to become parallel to the axis of coiling as the suture with the previous whorl is approached. The degree of whorl impression is slight; sutural indentation is deep.

The aperture is dorsally expanded at the latest growth stage, with a slightly flared brim. In dorsal view the extreme margin of this aperture is sub-circular in plan, without posterior expansion of the brim. The undersurface of the brim is convex such that the peristomial margin is slightly raised above the apertural plane. The apertural brim is considerably thickened.

A broad, shallow sinus culminates in a deep, narrow, median dorsal slit. The dorsal margins immediately ad- 


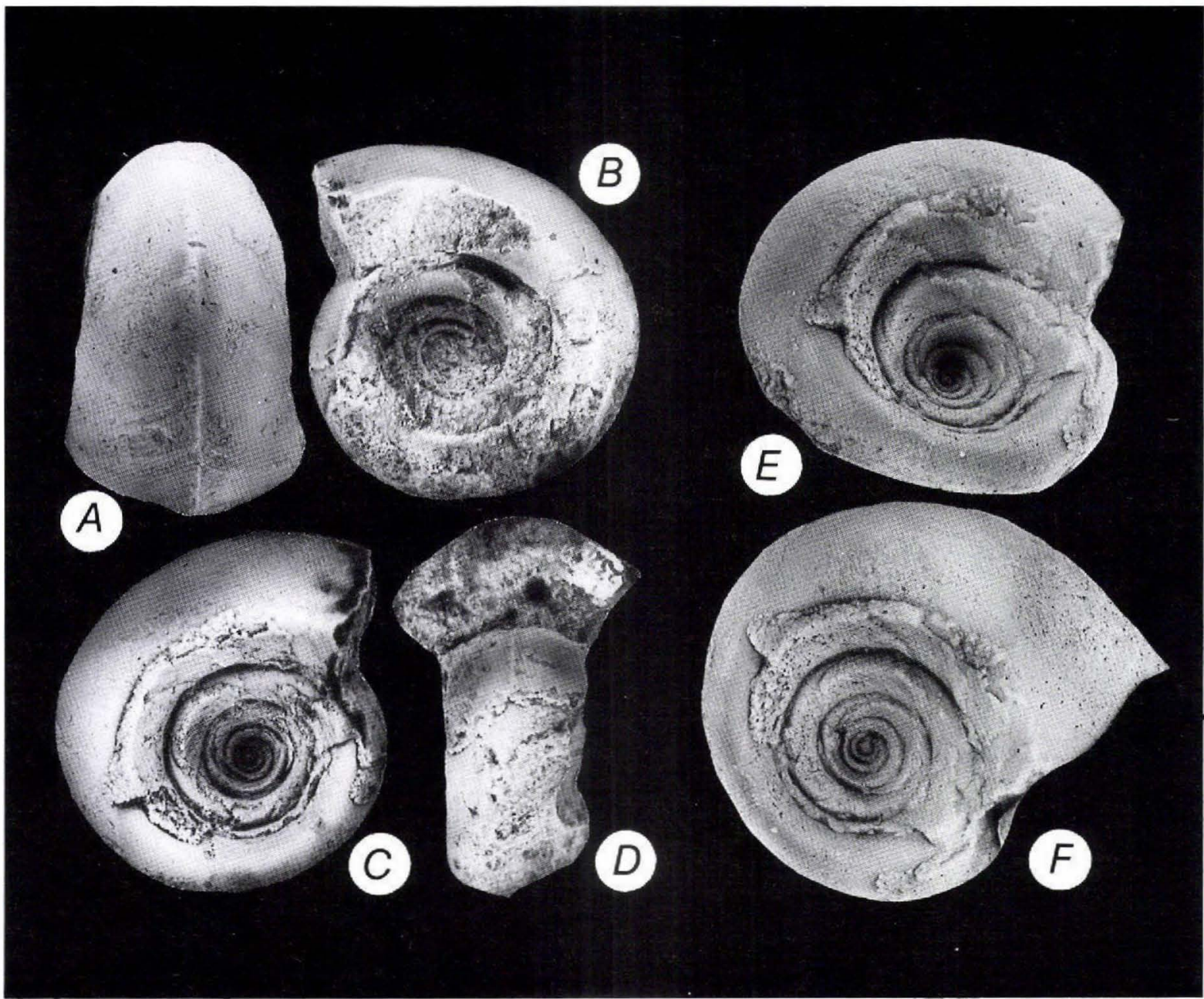

Fig. 24. Megalomphala contorta (Eichwald, 1860), Ordovician, Osmussaar, Estonia. A-D, the holotype, an internal mould carrying specimen number 308 in the Eichwald collection of the Chair of Historical Geology, University of Leningrad, $\times 2$. A, dorsal view showing the median dorsal band interpreted as indicating the presence of a selenizone and the transverse growth lines; B, C, lateral views showing widely phaneromphalous umbilici revealing about 6 whorls; D, apertural view. E, F, plaster casts of the same specimen prepared by Ellis L. Yochelson and preserved in the palaeobiological collections of the U.S. National Museum of Natural History (compare with $\mathrm{C}$ ), showing strongly opisthocline growth lines on the final and penultimate whorls in a shell fragment within the umbilicus, $\times 2.2$.

jacent to the slit are raised such that the slit and subsequent selenizone form the upper surface of a narrow, dorsal keel. The keel often lies in a shallow dorsal depression. In the largest specimens, a slit is not present immediately prior to the expanded and thickened brim and the dorsum is occupied by a long, narrow trema. The anterior margin in this final growth stage possesses only a shallow sinus.

Ornamentation consists of fine growth lines which slope obliquely backwards (adapically) from the suture and finally meet the slit at about 70 degrees. The shell is thin, but often conspicuously thickened at the acute dorso-lateral shoulders and, in later growth stages, around the apertural margin. Paired swellings are commonly present on the dorso-lateral areas, and are usually visible as periodic constrictions on internal moulds. Shell structure is unknown.

Discussion. Megalomphala taenia is one of a small group of species originally assigned to Megalomphala by Ulrich in Ulrich \& Scofield (1897, p. 850) and the only one of these of Silurian age. It is distinguished from most of these Ordovician species from the Baltic region figured by Koken \& Perner (1925) by its greater size, 

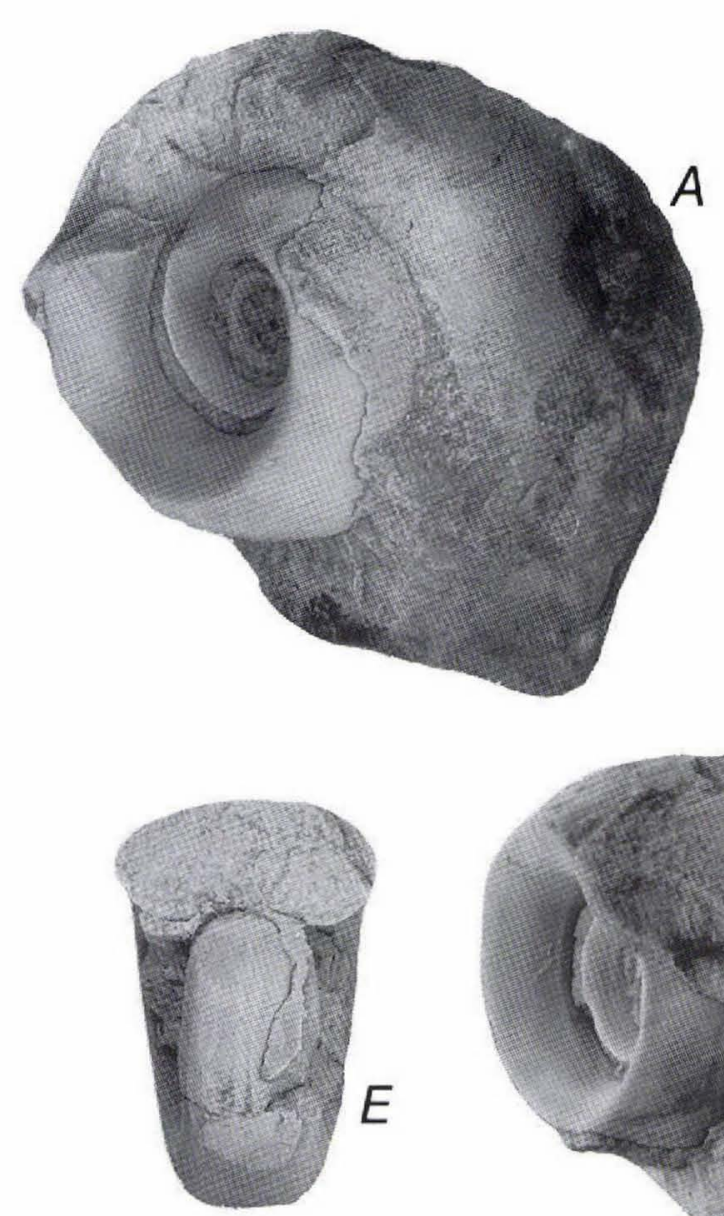
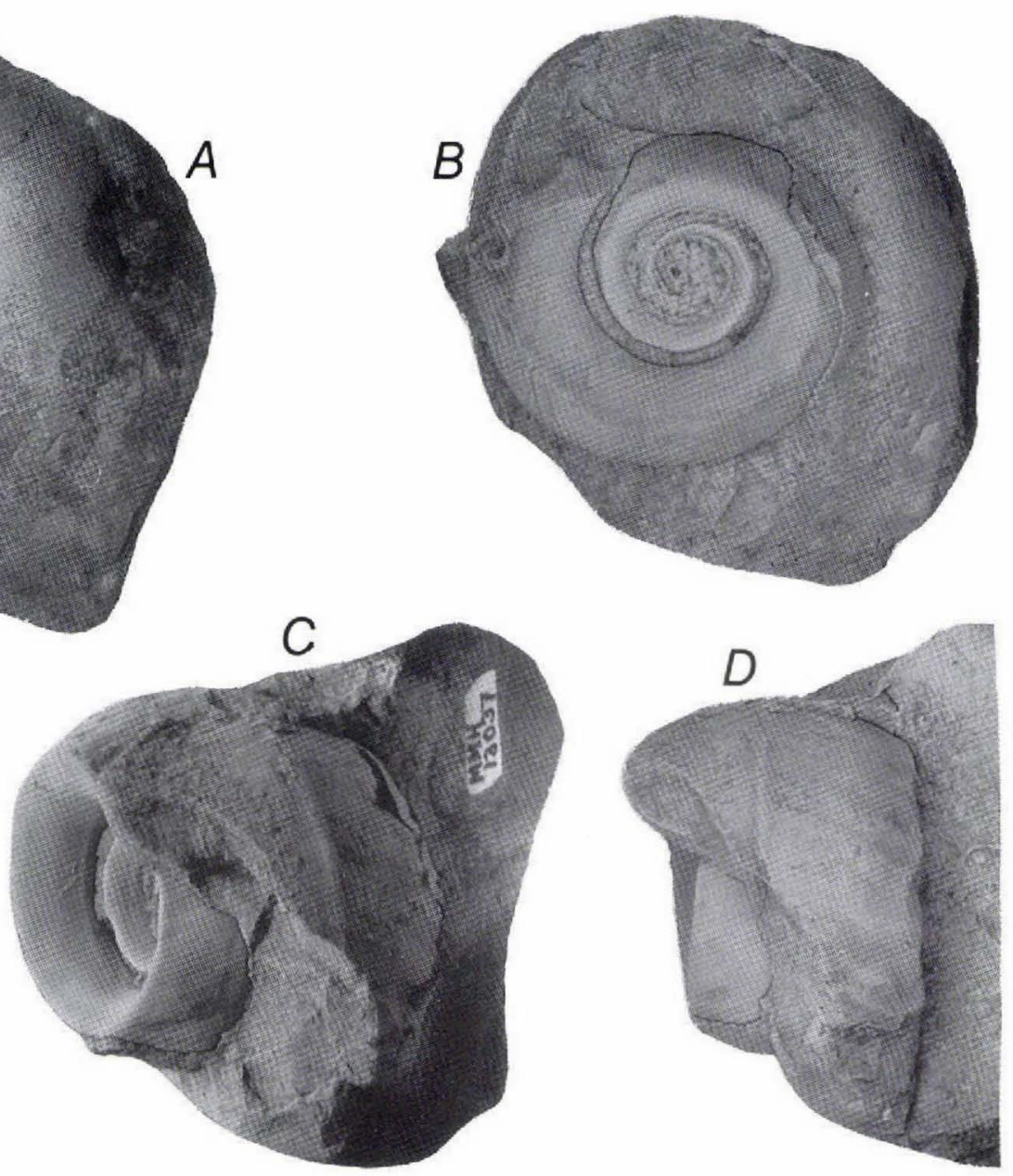

Fig. 25. Megalomphala taenia (Lindström, 1884), Silurian, Hemse Group, Östergarn, Gotland, Sweden. A-D, MMH 13.037, lectotype, the original of Lindström (1884, plate 7, figs 4,5), a largely exfoliated internal mould, $\times 1$. A, oblique umbilical view showing fine growth lines and the narrow selenizone preserved on the penultimate whorl; B, lateral view; C, oblique umbilical view as $\mathrm{A}$ but rotated to show the prominent raised selenizonal band on the final preserved growth stage. Note the spiral trace on the umbilical wall associated with shell musculature; D, dorsal view, as C. E, USNM 188177 , internal mould in apertural view.

more elliptical whorl profile and the tendency for the dorso-lateral shoulders to be acutely angular. It is larger and somewhat wider than the type species, $M$. contorta (Fig. 24), but resembles it in often having sharp peripheral angulations. Whorls in $M$. taenia are often more oval and less arched medially.

M. taenia resembles the contemporaneous Tremanotus compressus Lindström, 1884 with regard to whorl shape and coiling, although the slit and selenizone of the former contrast strongly with the row of median dorsal tremata present in $T$. compressus (Fig. 6). Confusion only occurs between internal moulds of the two species which lack traces of the mid-dorsal emargination; in most cases, $M$. taenia may be distinguished by greater lateral compression, more elliptical whorls and a sharp mid-dorsal crest.

The lectotype of $M$. taenia, an almost completely exfoliated internal mould, was described by Peel (1976) who reported spiral traces on the umbilical walls interpreted as representing traces of shell musculature (Figs 25A-D). The lectotype is a little wider, with more acutely angular shoulders to the whorls than most specimens of $M$. taenia. It preserves the characteristic middorsal ridge in the latest preserved growth stage (Fig. 25D), corresponding to the raised selenizone; traces of growth ornamentation and the narrow selenizone itself are also visible (Fig. 25A), but the aperture is not preserved. 


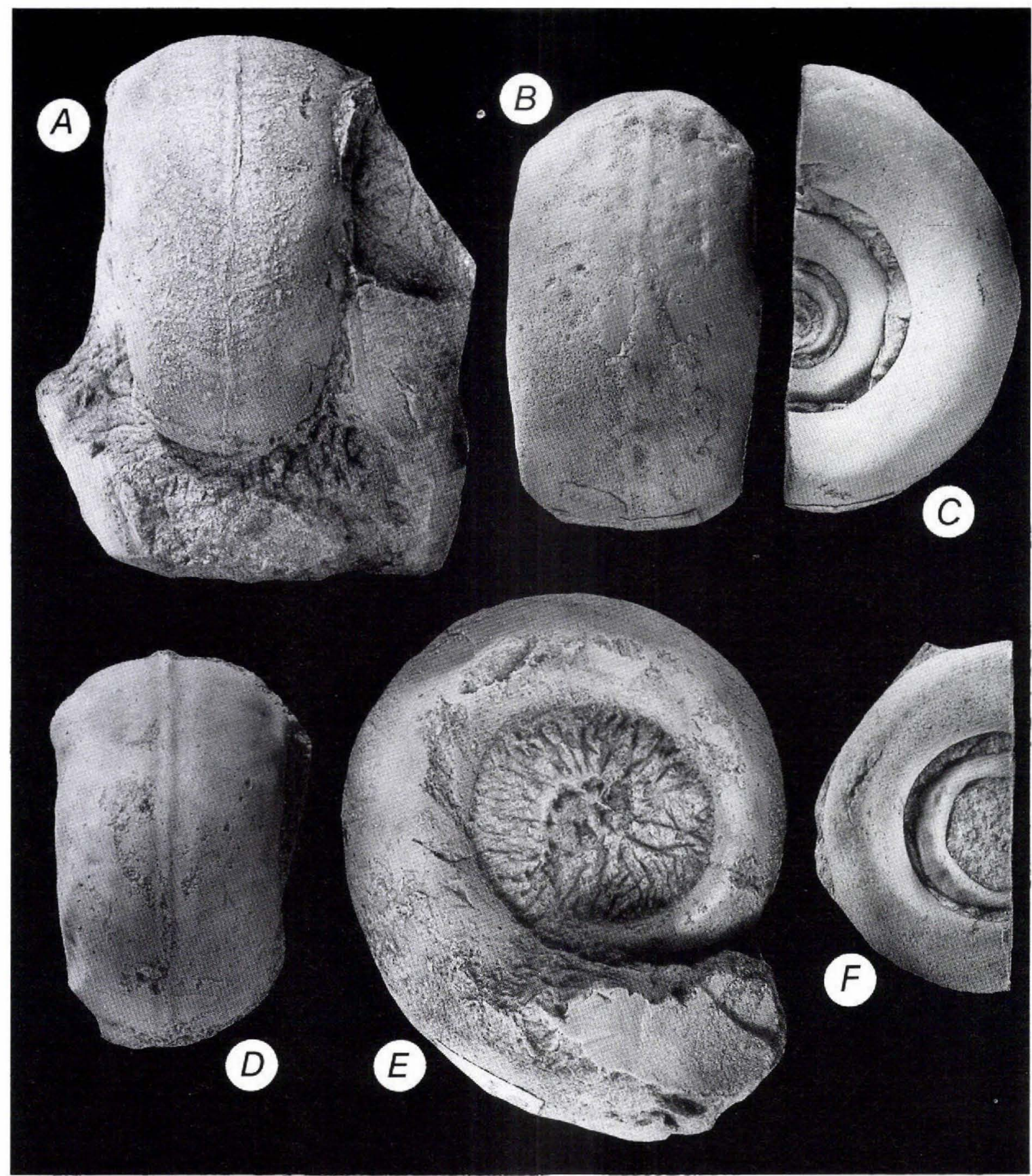

Fig. 26. Megalomphala taenia (Lindström, 1884), Silurian, Hemse Group, Östergarn, Gotland, Sweden, $\times 1.5$. A, E, Mo 151190 . $\mathrm{A}$, apertural view with the broken aperture at the base, showing the shallow sinus and median dorsal selenizone; E, lateral view. B, C, Mo 26559, internal mould, the original of Lindström (1884, plate 6, fig. 23) in dorsal and lateral views. The specimen has been polished transversely (see Fig. 27B). D, Mo 151201, dorsal view of internal mould showing the characteristic dorsal band reflecting the position of the selenizone. F, Mo 26560, internal mould, the original of Lindström (1884, plate 6, fig. 24) in lateral view. The specimen has been polished transversely (see Fig. 27A). 

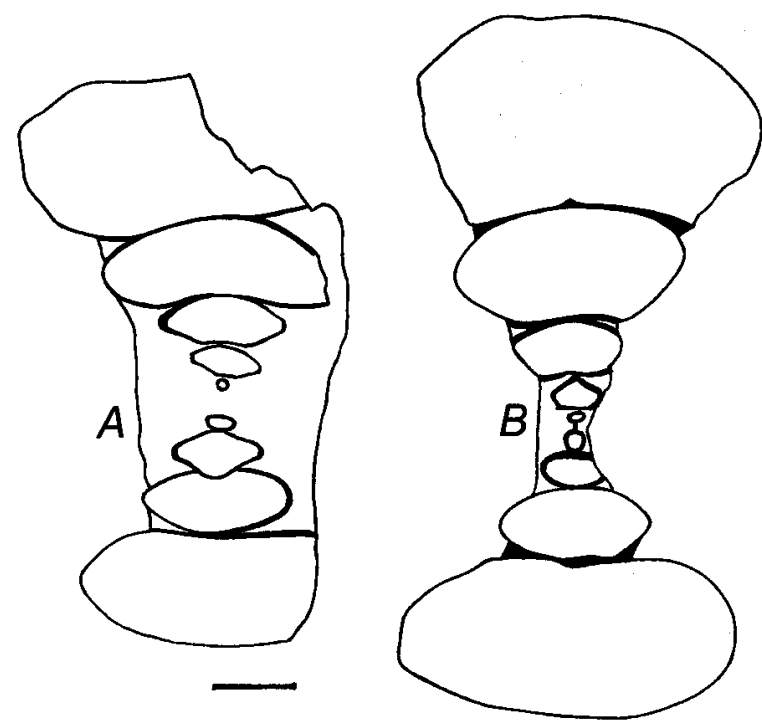

Fig. 27. Megalomphala taenia (Lindström, 1884), Silurian, Hemse Group, Östergarn, Gotland, Sweden. Camera-lucida drawings of transverse polished sections, scale-bar is $5 \mathrm{~mm}$. A, Mo 26560, compare Fig. 26F. B, Mo 26559, compare Fig. 64B,C.

The final growth stage, in which a bell-shaped aperture is developed as a result of a moderate increase in the rate of whorl expansion, is seen in a large specimen from Östergarn (Mo 151202, Fig. 28A, B). The open slit does not pass through the thickened anterior margin to the aperture and a single elongate trema is thus formed. A specimen from Grogarn (Mo 26639) preserved in apertural view shows the outer lip lacking any form of slit or selenizone (Fig. 28C).

\section{Megalomphala gotlandica sp. nov.}

Figs 29-31

Holotype. Mo 26976 from the red limestones of the Upper Silurian Hemse Group at Mannagårda, in the parish of Lye, Gotland, Sweden.

Figured material. In addition to the holotype, Mo 26520, Mo 26522, Mo 26579 from Mannagårda, and Mo 26504 from Lindeklint. All specimens from the Hemse Group, Gotland.

Additional material. About 40 specimens from the Hemse Group at Lindeklint, Sandarve, Linde, Mannagårda and Tanglings, Gotland.
Description. A species of Megalomphala Ulrich in Ulrich \& Scofield, 1897 with six or seven whorls. The nucleus is not known. The whorl cross-section is commonly sub-reniform, with whorl height about two thirds of whorl width. The dorsum is flatly arched and increases in curvature towards slightly angular dorso-lateral shoulders. The umbilical walls are flattened below the periphery, sloping adumbilically, but become strongly convex near the suture with the previous whorl. The umbilici are wide and open. Whorl embracement is about one fifth of the height of the previous whorl in the later growth stages; sutural indentation is deep, in detail. In the largest specimens, the aperture is expanded anteriorly and, to a lesser extent, laterally. The extreme margin of the aperture is ovate in plan view, with a slightly flared brim.

The dorsum is sinuate with the margins of the broad, shallow, sinus curving obliquely backward from the suture and passing into a deep, narrow, median dorsal slit. The slit forms the upper surface of a low keel which is located in a shallow median depression. In the expanded late growth stage, the anterior margin of the aperture lacks any form of emargination and a long, narrow trema is developed on the mid-dorsum.

Ornamentation consists of fine growth lines, paralleling the tangential aperture, and meeting the selenizone at about seventy degrees. The shell is generally thin but is considerably thickened around the apertural margin in the expanded stage. Shell structure is unknown.

Discussion. Megalomphala gotlandica is closely related to $M$. taenia from which it may be distinguished by its more rounded whorls, slightly greater lateral compression and the shape of the expanded aperture. The aperture at the expanded stage in $M$. taenia is circular in plan view and its margins are more flared than in M. gotlandica. In the latter species, the apertural margin tends to be elongated antero-posteriorly in plan view.

\section{Megalomphala marjorae sp. nov.}

Figs 32, 33

Holotype. Mo 26525 from the Silurian Klinteberg Formation, Vicklau, Gotland, Sweden.

Figured material. Mo 26526 and Mo 26655, also from Vicklau.

Additional material. Mo 26654, a poorly preserved specimen from Vicklau with the bell-shaped final growth stage present. 


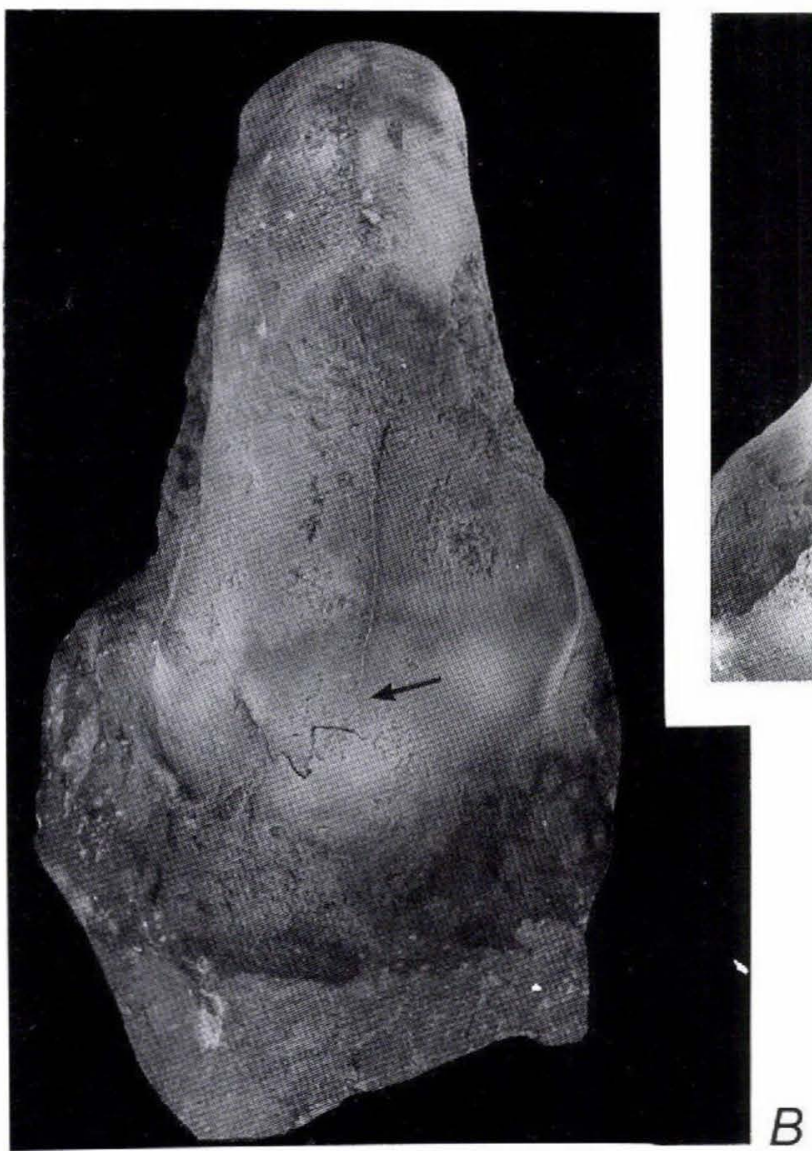

Fig. 28. Megalomphala taenia (Lindström, 1884), Silurian, Hemse Group, Gotland, Sweden, × 1. A, B, Mo 151202, Östergarn, lateral and antero-dorsal view of large internal mould showing the bell-shaped final growth stage. Note how the slit in B stops (arrow) prior to the anterior margin. C, Mo 26639, Grogarn (Östergarn), apertural view showing the apertural margin without traces of the anterior slit or selenizone.

Description. Species of Megalomphala Ulrich in Ulrich \& Scofield, 1897 with, for the genus, relatively narrow umbilici. Nucleus and early whorls not known. The whorl profile is transversely elliptical with a shallowly convex dorsum passing around regularly convex lateral areas onto shallowly convex or adumbilically sloping umbilical walls; in later growth stages, the dorsum may become slightly angulated medially. The umbilici are widely phaneromphalous, about one third of the total length. Whorls embrace the dorsal quarter of the previous whorl and sutural indentation is deep, in detail. The aperture in the final growth stage is expanded, bellshaped, but the nature of the apertural margin at this growth stage is uncertain.

The dorsum is sinuate, with a broad, shallow sinus culminating in a slit of unknown depth; the selenizone is raised and narrow.

Ornamentation consists of oblique growth lines which 


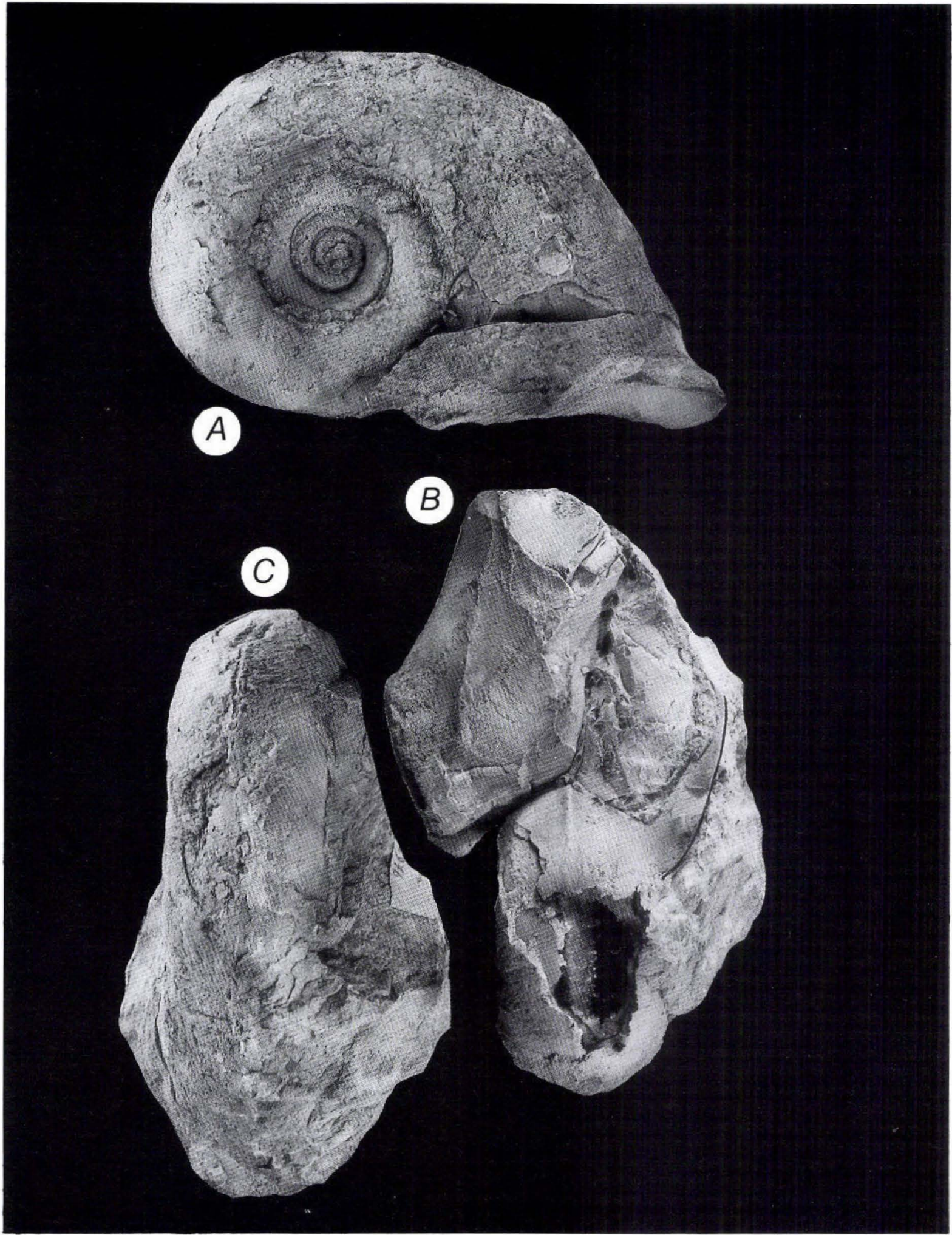

Fig. 29. Megalomphala gotlandica sp. nov., Silurian, Hemse Group, Mannagărda in the parish of Lye, Gotland, Sweden. Mo 26976, holotype, $\times 1$. A, lateral view showing the wide umbilicus and the bell-shaped final growth stage (right); B, apertural view, the margin of the aperture on the right side is inked; $\mathrm{C}$, dorsal view showing the poorly preserved median dorsal selenizone (sediment comprising the right side of the photograph has been trimmed away). 


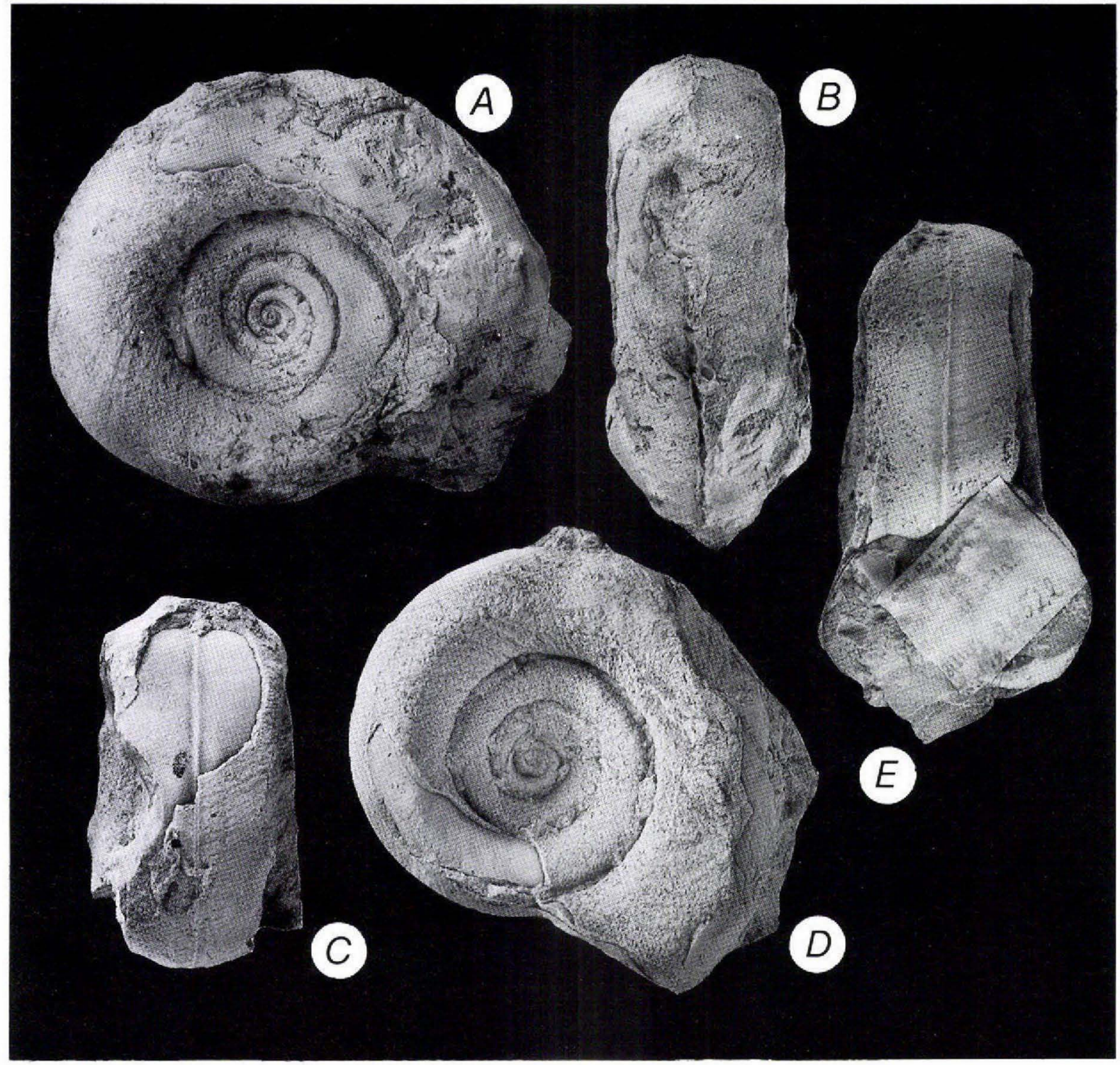

Fig. 30. Megalomphala gotlandica sp. nov., Silurian, Hemse Group, Mannagårda in the parish of Lye, Gotland, Sweden. A, B, Mo 26520 in lateral and dorsal views, $\times 1$. C-E, Mo 26522, juvenile stages of an example with relatively elliptical whorls very similar to M. taenia, $\times 1.5$. C, dorsal view showing growth ornamentation, the narrow selenizone (below) and the characteristic elevated band on the internal mould; D, lateral view showing the wide umbilicus and strongly opisthocline growth ornamentation indicating a tangential aperture; E, apertural view, with the aperture below, showing the narrow raised selenizone and growth ornamentation.

slope backwards (adapically) from the suture with the previous whorl, and which may be slightly lamellar in the later growth stages. The shell is thin, becoming thicker in the final growth stage. Shell structure is not known.

Discussion. Megalomphala marjorae differs from other
Gotland species assigned to the genus in having relatively narrow umbilici. These are about one third of the total length, as compared with about half the total length in $M$. taenia and $M$. gotlandica. However, the large number of whorls (6), nature of the ornamentation and shape of the bell-shaped final growth stage warrant assignment to Megalomphala. 


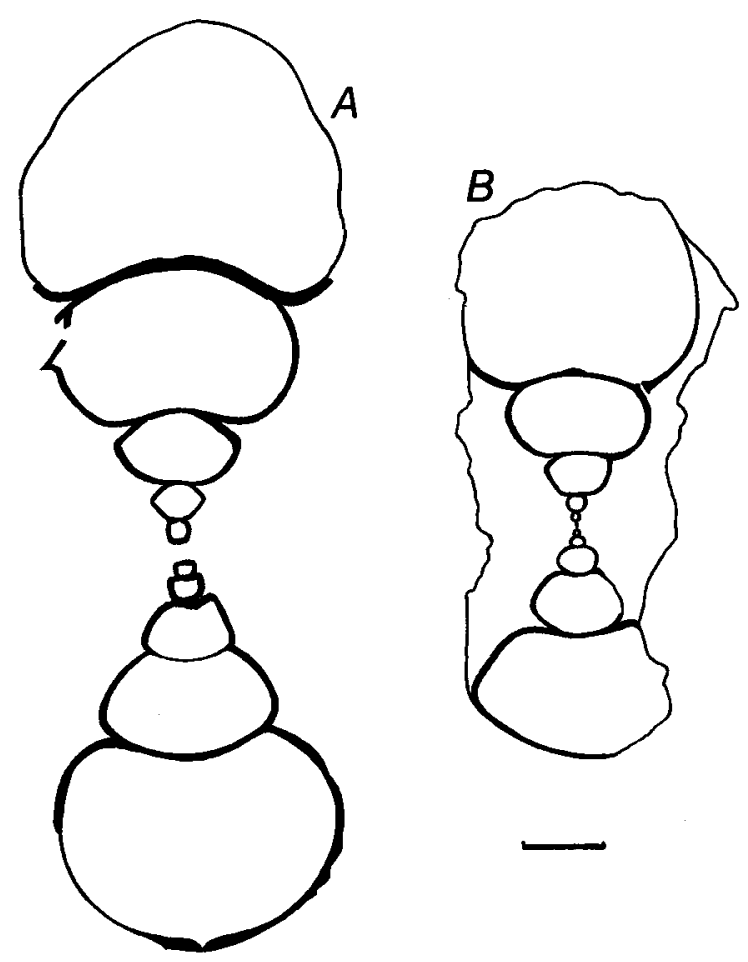

Fig. 31. Megalomphala gotlandica sp. nov., Silurian, Hemse Group, Gotland, Sweden. Camera-lucida drawings of transverse cross-sections, scale-bar is $5 \mathrm{~mm}$.. A, Mo 26579, Mannagårda in the parish of Lye, note how the dorsum becomes inflated in later growth stages. B, Mo 26504, Lindeklint.

\section{Megalomphala cf. M. marjorae}

Figs 34-36

Figured material. MGUH 20.843-20.845 from GGU collection 184128, Samuelsen Høj Formation of the Washington Land Group (Early Silurian), at Samuelsen Høj, central Peary Land, central North Greenland (Fig. 2). Collected by John S. Peel 8th July 1974.

Discussion. Several imperfectly preserved specimens from the Samulesen Høj Formation (Late Llandovery, Early Silurian) of Peary Land are compared with $M$. marjorae from Wenlock deposits in Gotland. The Peary Land specimens show the relatively high degree of whorl expansion and relatively (for the genus) narrow umbilici characteristic of $M$. marjorae, but are slightly narrower at the same size with less lenticular whorls. They are noteworthy on account of the well preserved earlier whorls not well known in the Gotland type suite. The apertural margin is not preserved in any of the available material.
Megalomphala wilfredi sp. nov. Figs 37, 38

Holotype. Mo 26648 from the Lower Silurian Slite Group of Klints in the parish of Othem, Gotland, Sweden.

Figured material. In addition to the holotype, Mo 26647 from Klints, and Mo 26651 from Malms in Hellvi parish. All from Slite Group.

Additional material. Mo 26649, also from Klints.

Description. A species of Megalomphala Ulrich in Ulrich \& Scofield, 1897 lying close to the morphological circle of the type species. The internal height of the whorls is about two thirds of the corresponding whorl width. The shallowly convex dorsum in early whorls passes via peripheral dorso-lateral shoulders onto convex adumbilically sloping umbilico-lateral walls; sudden increase in curvature near the suture with the previous whorl produces deep sutural indentation. Maximum whorl width in earlier whorls is high on the whorl profile but becomes progressively lower during ontogeny. In the final whorl the profile shows a uniformly convex dorsal area passing onto strongly convex umbilico-lateral areas. The umbilici are wide and open, with whorl embracement about one third of the height of the previous whorl.

The aperture is poorly known but may be slightly bell-shaped in the final growth stage. Growth lines indicate tangential margins in earlier growth stages, producing a wide, shallow, sinus and culminating in a deep, narrow, median slit. The selenizone is raised between the acutely upturned lateral marginal lamellae of the slit.

Ornamentation consists of growth lines which slope obliquely backwards (adapically) from the suture to meet the selenizone at about 70 degrees; growth lines may be lamellar in later growth stages. The shell is of moderate thickness; its structure is unknown.

Discussion. Megalomphala wilfredi is that Silurian species of Megalomphala which compares most closely to the various Ordovician species described by Koken \& Perner (1925). Among Silurian species from Gotland, it is distinguished from $M$. taenia and $M$. gotlandica by its deeper whorl embracement and smaller size. In addition, $M$. taenia has more strongly elliptical whorls with strongly angulated dorso-lateral shoulders. Megalomphala marjorae has narrower umbilici and a greater rate of whorl expansion than $M$. wilfredi. 


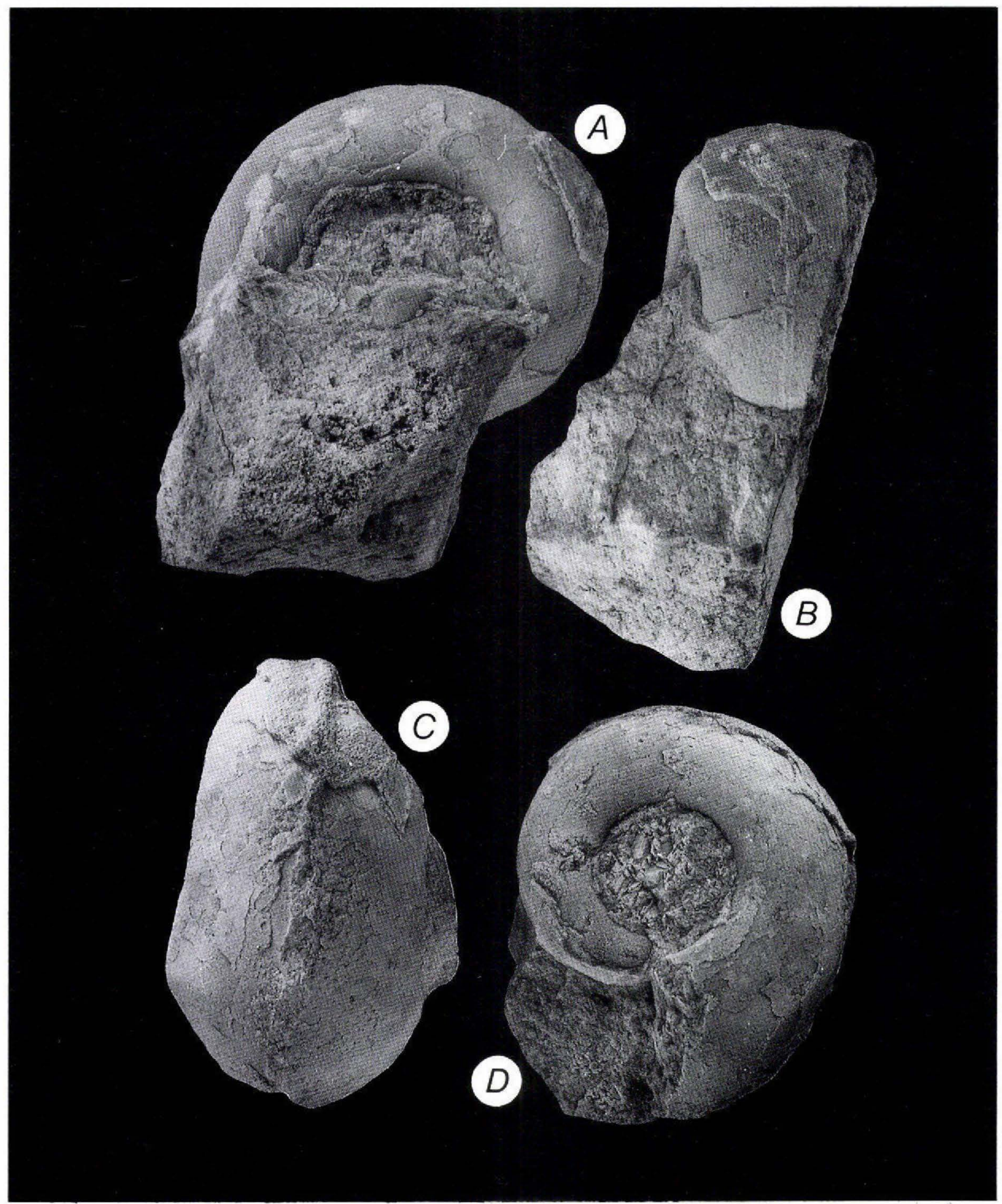

Fig. 32. Megalomphala marjorae sp. nov., Silurian, Klinteberg Formation, Vicklau, Gotland, Sweden, $\times 1.5$. A, B, Mo 26525 , holotype, largely exfoliated internal mould in lateral and postero-dorsal views. Note the narrow selenizone in B. C, D, Mo 26655, internal mould in dorsal and lateral views, the latter showing the relatively narrow (for the genus) umbilicus. 


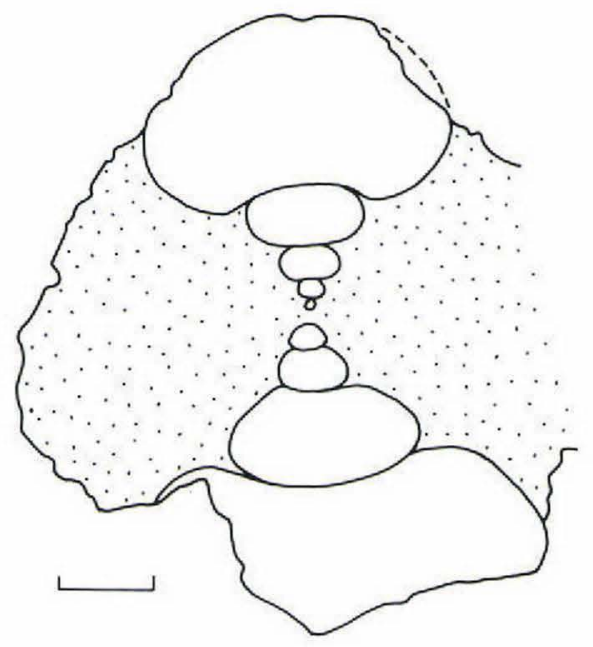

Fig. 33. Megalomphala marjorae sp. nov., Silurian, Klinteberg Formation, Vicklau, Gotland, Sweden. Camera-lucida drawing of transverse cross-section of early whorls of Mo 26526, showing the relatively high rate of whorl expansion. Scale bar is 5 $\mathrm{mm}$.

As with the type species of Megalomphala, the presence of a bell-shaped final growth stage has not been demonstrated in $M$. wilfredi, but the species is rare and the few available specimens have imperfectly preserved apertures.

\section{Megalomphala dawesi sp. nov.}

Fig. 39

Holotype. MGUH 20.846 from GGU collection 82341, from the Washington Land Group (Early Silurian), Korsgaard Bjerg, Nyeboe Land, western North Greenland (Fig. 2), collected by P. R. Dawes 9th July 1966 (see Dawes \& Peel, 1984, pp. 35-36).

Fig. 34. Megalomphala cf. $M$. marjorae. Silurian, Washington Land Group, Samuelsen Høj Formation, Samuelsen Høj, central Peary Land, central North Greenland. MGUH 20.843 from GGU 184128. A specimen with the aperture not preserved, broken under collection such that the inner whorls $(D-G, \times 2)$ were photographed prior to re-assembly of the entire specimen $(\mathrm{A}-\mathrm{C}, \times 1.5)$. A, oblique lateral view; $\mathrm{B}$, dorsal view; $C$, lateral view; $D$, apertural view showing prominent medial keel and dorsal growth ornamentation; E, F, oblique-lateral and lateral views showing ornamentation on the umbilical walls; $G$, dorsal view showing the median dorsal keel broken away to produce a selenizone with jagged margins.
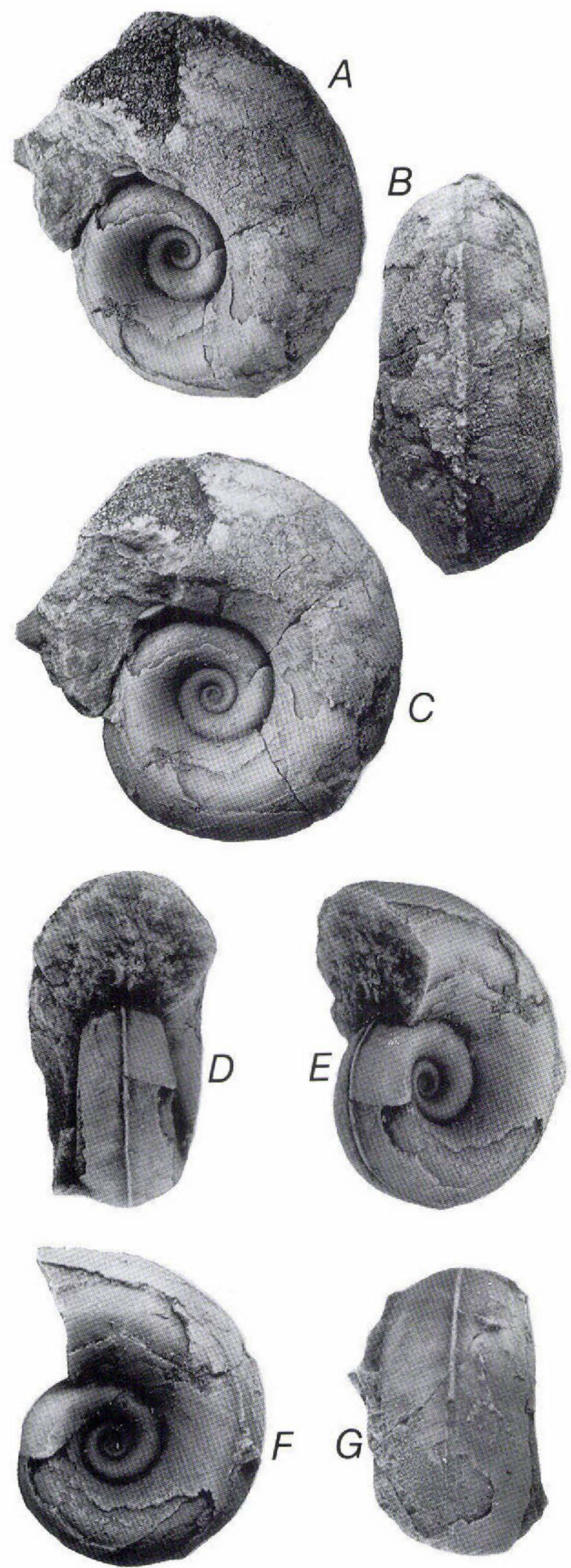


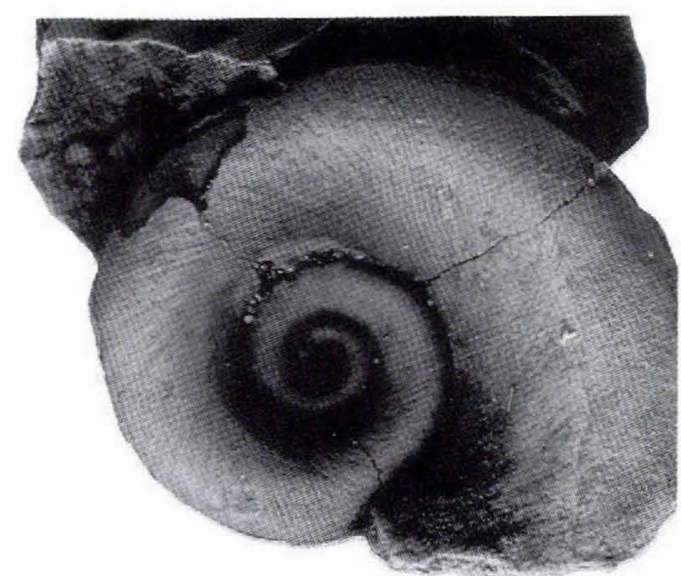

Fig. 35. Megalomphala cf. M. marjorae. Silurian, Washington Land Group, Samuelsen Høj Formation at Samuelsen $\mathrm{H} \varnothing \mathbf{j}$, central Peary Land, central North Greenland. MGUH 20.844 from GGU collection 184128. Fragment of early whorls in lateral view showing the fine growth ornamentation, tangential to the previous whorl, $\times 4$.

Figured material. MGUH 20.847 from GGU collection 83404 , same locality as the holotype.

Description. A species of Megalomphala Ulrich in Ulrich \& Scofield, 1897 of unusually small size. Five whorls are present with the earliest whorls seemingly lenticular, with whorl width greater than whorl height. At about half a whorl prior to the final growth stage the whorl profile is almost equidimensional, with width only slightly greater than height. At this stage the uniformly convex dorsum increases its convexity with passage around the peripheral lateral areas onto the somewhat flattened umbilical whorls; lateral angulations or shoulders are not present. Whorl embracement is slight with deep indentation of the sutures; the umbilici are wide and open. The aperture at this growth stage is tangential to the previous whorl, as indicated by growth lines. These sweep strongly back, adapically, across the umbilical walls but, with passage onto the dorsal surface, they form a broad and shallow sinus which occupies the entire dorsal surface. The sinus passes angularly into a narrow, median dorsal slit and selenizone; the depth of the slit is not known. A shallow sinus is formed at the transition from the umbilical walls to the dorsal surface. The lateral margins of the slit and resultant selenizone are raised to form a keel which is narrower at its upper surface. Breakage of the keel produces a relatively wider selenizone with lunulae but with jagged lateral margins.

During the final fraction of the whorl the rate of whorl expansion increases to produce the bell-shaped final growth stage and the flared aperture. The median dorsal keel can be traced to within a few degrees of rotation of the brim but it is not possible to ascertain either the presence or length of an eventual trema.

Ornamentation consists of slightly lamellose transverse growth lines. The shell is thin, without observed thickening in the apertural region of the final growth stage; its structure is not known.
Fig. 36. Megalomphala cf. M. marjorae. Silurian, Washington Land Group, Samuelsen $\mathrm{H} ø j$ Formation at Samuelsen Høj, central Peary Land, central North Greenland. MGUH 20.845 from GGU collection 184128 . Camera-lucida drawings of transverse cross-section, with inner whorls enlarged (left), showing the expansion of the final growth stage characteristic of the species. Note that the half whorl prior to the final growth is not preserved in the specimen as sectioned. Thus, in the illustration to the right, the lowest whorl cross-section shown lies one and a half whorls prior to the final whorl cross-section (top); this final growth stage occurs ontogenetically later than the final preserved growth stage in the specimen illustrated in Fig. 34. The scale-bar is $5 \mathrm{~mm}$ long.

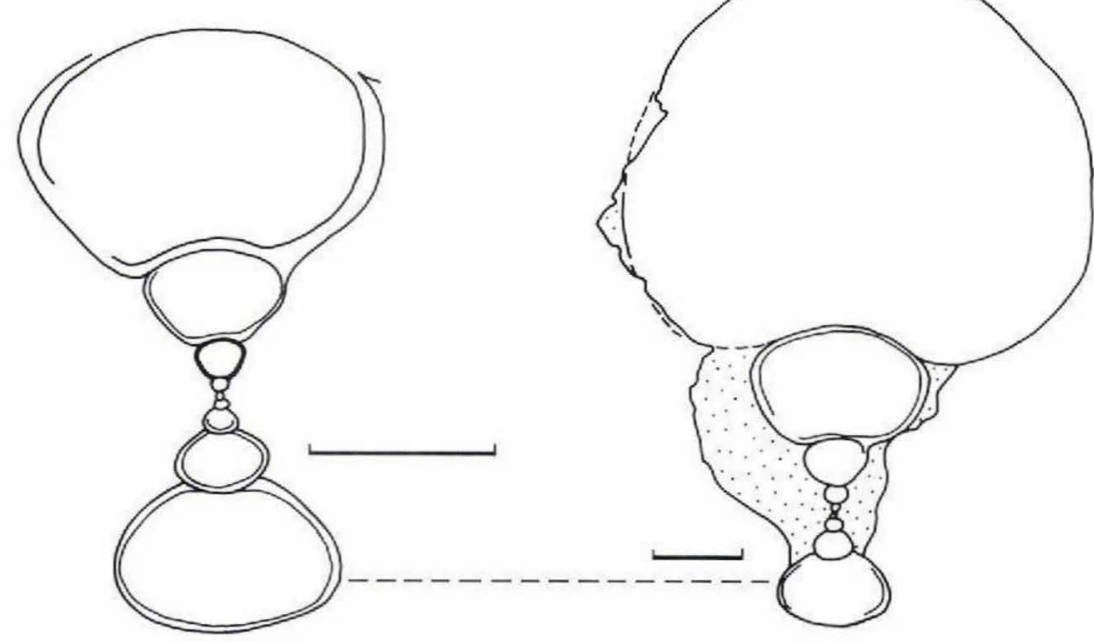




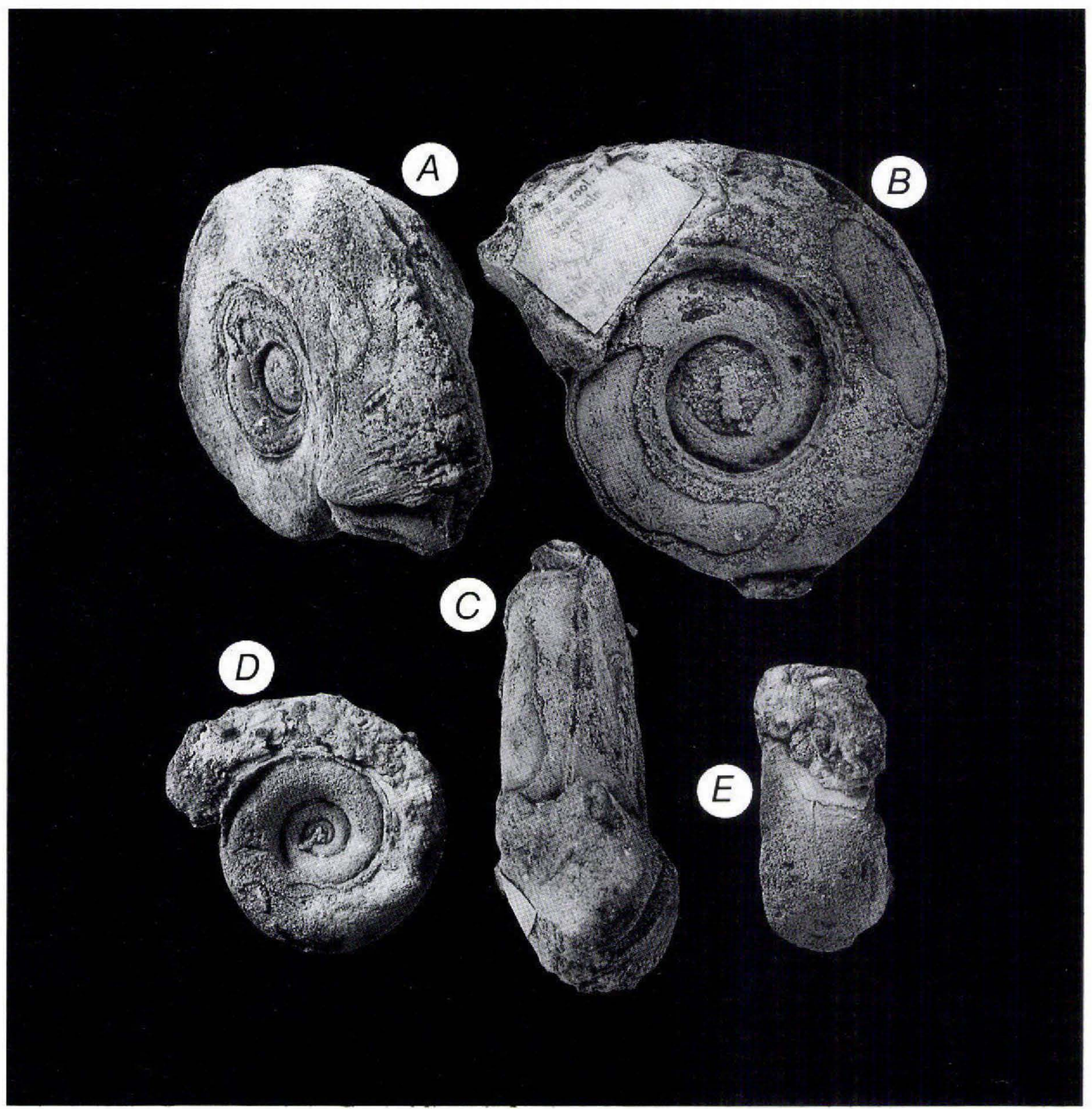

Fig. 37. Megalomphala wilfredi sp. nov., Silurian, Slite Group, Gotland, Sweden, $\times$ 1.6. A-C, Mo 26648, holotype, Klints in the parish of Othem. A, oblique antero-dorsal view showing the lamellose growth lines near the aperture of the weathered specimen; lateral view; $\mathrm{C}$, apertural view, with aperture below, showing the narrow selenizone. D, E, Mo 26651, paratype, Malms in the parish of Hellvi, juvenile specimen in lateral and apertural view.

Discussion. This species is based on two imperfectly preserved specimens from the Lower Silurian of Nyeboe Land. The holotype is broken into two parts; one part preserves the final quarter of a whorl, showing the bell-shaped final growth stage, and an external impression of the earlier whorls, while the second part preserves all but the final half whorl. In the paratype, from the same locality and horizon, the umbilical margin of the bell-shaped aperture and much of the previous whorl are preserved, although the other side of the shell is heavily weathered.

The specimens were identified as Salpingostoma(?) boreale Whiteaves, 1904 by Dawes \& Peel (1984, p. 36), a species of similar size originally described from the 


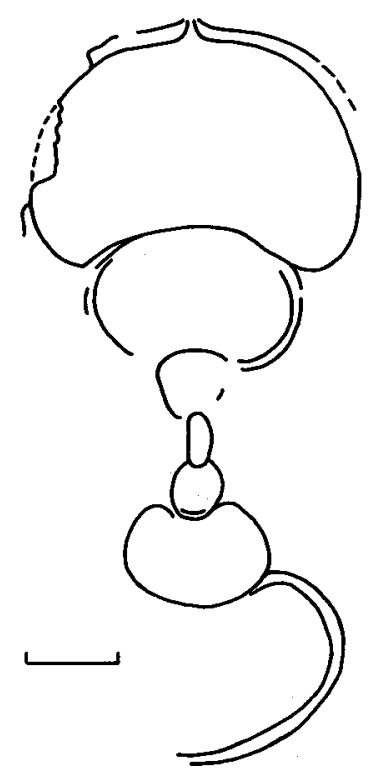

Fig. 38. Megalomphala wilfredi sp. nov., Silurian, Slite Group, Klints in the parish of Othem, Gotland, Sweden. Cameralucida drawing of Mo 26647, paratype, a transverse crosssection showing the reniform whorl cross-section, scale-bar is 5 $\mathrm{mm}$.

Lower Silurian of the Hudson Bay Lowlands of Canada (cf. Whiteaves, 1906 and Peel, 1972, pp. 420-421). Megalomphala dawesi is distinguished from Whiteaves' species by its wider umbilici and the lack of the spiral ornamentation held to be characteristic of $S$. boreale. The wider umbilici reflect the presence of five whorls and the Nyeboe Land specimens are referred to Megalomphala on the basis of this character. Whiteaves (1906, p. 258) recorded three rounded whorls in the Canadian species.

Megalomphala dawesi is distinguished from other SiIurian species of Megalomphala by virtue of its small size, the holotype being less than $25 \mathrm{~mm}$ in length compared to the approximately $90 \mathrm{~mm}$ of the holotype of $M$. gotlandica. However, the presence of the bellshaped final growth stage in both the holotype and the paratype indicates a mature shell.

Whorls are less lenticular in cross-section than in $M$. taenia and less rapidly expanding than in $M$. marjorae. The partially exfoliated dorsal area in the holotype shows the characteristic narrow median dorsal keel flanked by spiral depressions seen in $M$. taenia (Figs 26D, 28C) and $M$. gotlandica (Fig. 30C). Growth ornamentation is clearly visible in the holotype of $M$. dawesi showing the strongly oblique, tangential, inclination on the umbilical walls and the broad, shallow, sinus on the dorsum passing angularly into the narrow slit and seleni- zone. A shallow sinus occurs on the rounded dorsolateral shoulder.

\section{Megalomphala septentrionale (Poulsen, 1974) \\ Fig. 40}

1974. Salpingostoma septentrionale Poulsen, p. 7, pl. 1 , figs 7,8

Holotype. MMH 13.677, a largely exfoliated internal mould from the Silurian Washington Land Group, Kap Morton, Washington Land, western North Greenland.

Description. A species of Megalomphala Ulrich in Ulrich \& Scofield, 1897 in which the whorl profile in the laterally compressed later whorls is unusually high, without peripheral angulations. Five or six whorls are probably present within the widely phaneromphalous umbilici which, at the latest preserved growth size in the only known specimen, are about one third of the total length. During the final whorl, whorl height increases to be more than whorl width, but only with slight concomitant increase in width.

The aperture is tangential, with growth lines curving obliquely backwards (adapically) from the suture towards the mid-dorsum. A narrow slit extends through more than a quarter of a whorl and generates a narrow, median dorsal selenizone which is bordered by fine threads and ornamented with abundant lunulae. The slit does not penetrate the anterior margin of the shell.

Ornamentation seemingly consists only of growth lines sweeping obliquely across the shell parallel to the tangential aperture. The shell is apparently thin; its structure is unknown.

Discussion. Poulsen (1974) assigned this species to Salpingostoma reporting a short trema only about $10 \mathrm{~mm}$ long, although the trema in fact extends over more than a quarter of the circumference of the final whorl. He made no comparison with other described species.

The Washington Land species is assigned to Megalomphala on account of its wide umbilici, high number of whorls and the absence of a slit in only the last fraction of the whorl (the aperture is not preserved but is clearly very near to the preserved broken margin). Megalomphala septentrionale approaches $M$. wilfredi in size and degree of lateral compression, but has much narrower umbilici. It also lacks the angular peripheral shoulders and flattened umbilical walls of $M$. wilfredi (Fig. 38). 

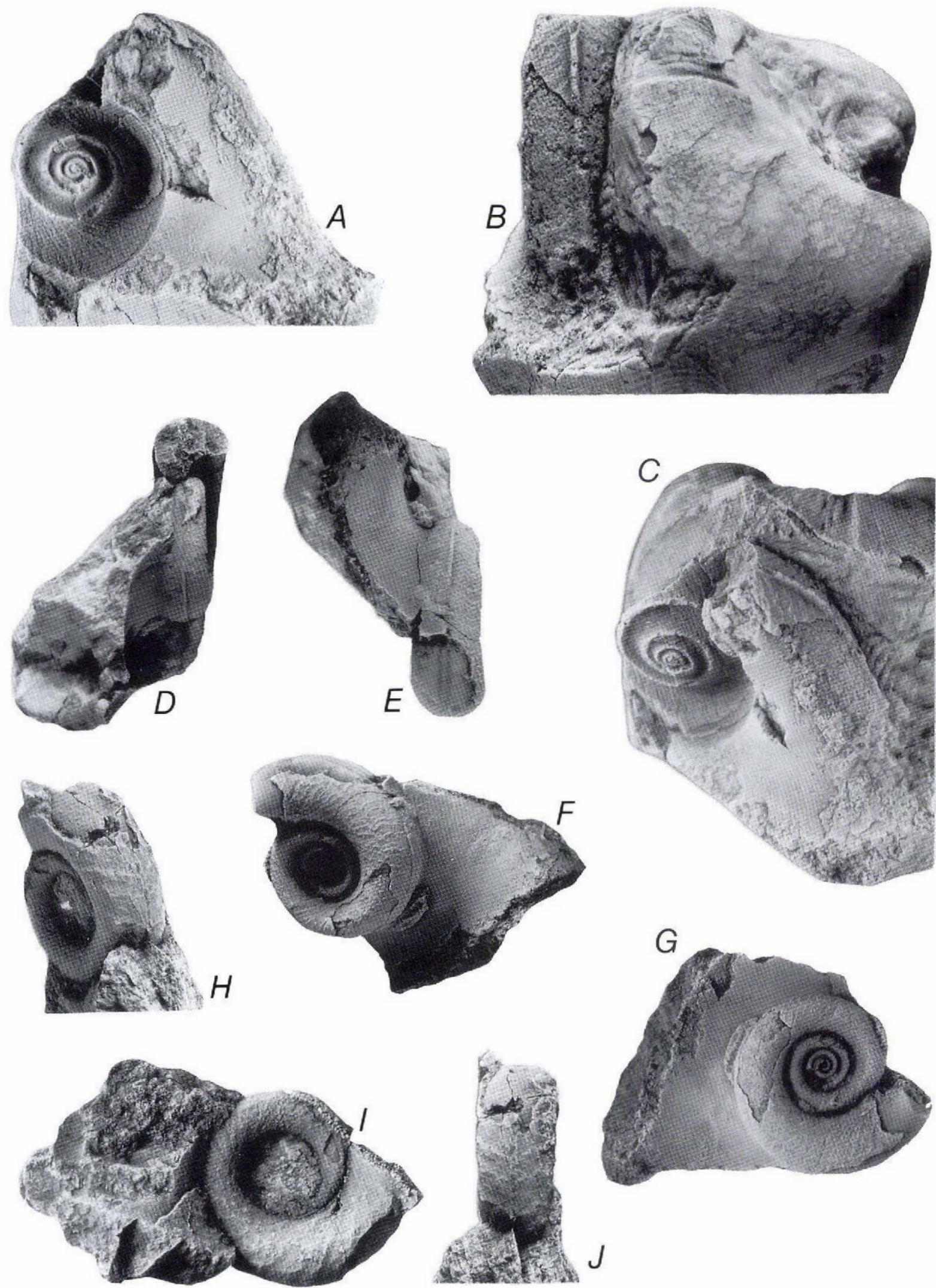
Fig. 40. Megalomphala septentrionale (Poulsen, 1974), Lower Silurian, Washington Land Group, Kap Morton, Washington Land, western North Greenland. MMH 13.677, largely exfoliated internal mould, holotype and only known specimen, $\times 1.5$. A, lateral view showing the expanded late growth stage and faintly preserved growth lines; B, apertural view, with aperture below, showing the narrow selenizone; $\mathrm{C}$, dorsal view of latest preserved growth stage showing the absence of the open slit from the final preserved
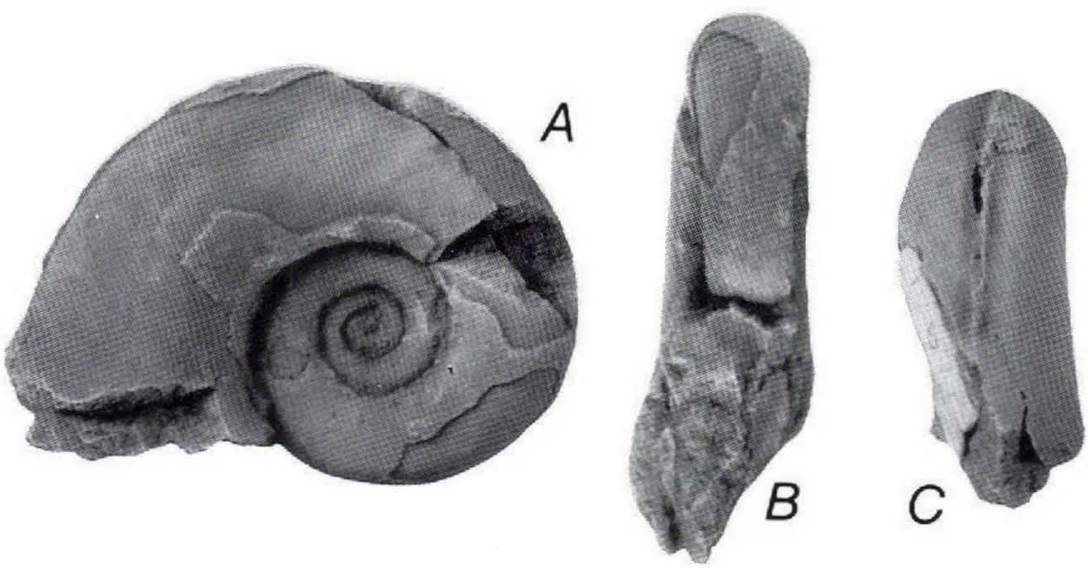
fraction of the whorl.

\section{Genus Offleya Poulsen, 1974}

Type species. Offleya inexpectata Poulsen, 1974.

Diagnosis. Essentially a bucaniiform bellerophontacean with a sub-circular whorl profile, tangential aperture producing oblique growth lines and (probably) a deep, narrow slit generating a median selenizone. The rate of whorl expansion is low and the number of whorls is high

Fig. 39. Megalomphala dawesi sp. nov. Silurian, Washington Land Group, Korsgaard Bjerg, Nyeboe Land, western North Greenland. A-G, holotype, MGUH 20.846 from GGU collection $82341, \times 2.5$. The holotype is broken into two parts, such that the final growth stage is preserved together with an external mould of the early whorls (A-C), while the early whorls are preserved together with an external mould of the final growth stage (D-G). The specimen is preserved within a pentameroid brachiopod (B). A, lateral view showing apertural expansion and the brim; $\mathrm{B}$, dorsal view of the final quarter whorl showing growth ornamentation and the median dorsal keel; C, oblique lateral view showing the apertural expansion near the suture with the previous whorl; D, early whorls in apertural view, with the external mould of the later growth stage below; E, dorsal view of early whorls, note the median ridge bounded by narrow spiral grooves on the internal mould (below); F, oblique lateral view of early whorls showing the lamellose growth ornamentation and the suggestion of a lateral sinus; specimen oriented with the true aperture uppermost at the right; G, lateral view of early whorls, oriented with the true aperture downwards at the left, showing tangential ornamentation. H-J, paratype, MGUH 20.847 from GGU collection $83404, \times 2.5$. Fragment of early whorls and apertural margin showing the selenizone with irregular margins resulting from breakage of the median dorsal keel. Growth ornamentation is periodically lamellose and slightly crenulate. $\mathrm{H}$, oblique dorsal view; I, lateral view with aperture to left; J, dorsal view. (at least 5), producing a narrow shell with very wide, open umbilici.

Ornamentation consists of strong spiral ribs crossed by crenulate growth lines which produce a honey-comb pattern.

Description. As for the type species, below.

Discussion. Offleya can be compared closely to Phragmolites Conrad, 1838, well known from the Ordovician of North America and the Baltic region (Ulrich \& Scofield, 1897; Koken \& Perner, 1925). It is distinguished from species assigned to this latter genus by its strong lateral compression, unusually wide umbilici and prominent spiral ornamentation.

\section{Offleya inexpectata Poulsen, 1974 Fig. 41}

\section{Offleya inexpectata Poulsen, pp. 7-8, pl. 1, figs 9-11.}

Holotype. MMH 13.678 from the Washington Land Group (Early Silurian), northern coast of Offley $\varnothing$, western North Greenland.

Description. The type and only known species of $O f$ fleya Poulsen, 1974 with at least five whorls. The nucleus and early whorls are poorly known. In the final preserved whorl, the whorl profile is almost circular, with whorl height slightly greater than whorl width. The umbilici are very widely phaneromphalous, comprising half the length at the final preserved growth stage. Whorl embracement is slight; sutures are broadly shallow but deeply incised in detail. 
The aperture is not known but growth lines indicate that the plane of the aperture is almost tangential to the earlier coiled portion of the shell. Growth lines curve obliquely backward from the suture, becoming shallowly concave adaperturally as they pass onto the dorsal surface to produce a broad, shallow sinus. The sinus passes abruptly into a narrow median slit generating a selenizone. The sides of the slit are lamellose, producing a raised carina which is triangular in cross-section; the slit itself (or the resultant selenizone) forms the top of the carina.

Ornamentation consists of spiral cords crossed by abundant fine growth lines. Periodic lamellose growth lines are flared and crenulated perpendicular to the growing edge, producing a honey-comb pattern. On the flanks, the interference pattern produced by these crenulate growth lamellae gives the impression of transverse ornamentation swinging strongly adaperturally from the suture. The shell is seemingly thin, its structure is not known.

Discussion. Offleya inexpectata is known only from the holotype, described by Poulsen (1974). In general proportions and ornamentation, $O$. inexpectata is very reminiscent of Boiotremus fortis (Frech, 1894) from the Lower Devonian Koneprusy Limestone of Czechoslovakia (Horny, 1963), a similarity undoubtedly reflecting the similar reef environment of both occurrences. However, $O$. inexpectata is smaller and lacks the median row of tremata characteristic of the Czechoslovakian species.
The final preserved growth stage of the holotype of $O$. inexpectata shows a fragment of the raised, angular selenizone, but the depth of the slit and the presence or absence of a trema are not known.

Offleya inexpectata is quite similar to Megalomphala wilfredi from the Slite Group at Klints in the parish of Othem, Gotland, but this species has a slightly greater rate of whorl expansion, narrower umbilici (about $40 \%$ of the length) and lacks the coarse spiral ornamentation seen in Offleya. M. septentrionale (Poulsen, 1974), from the Silurian of nearby Washington Land, has narrower umbilici and lacks the prominent spiral and reticulate ornamentation characteristic of Offleya.

Phragmolites hyperboreus Troedsson, 1928 from the Upper Ordovician Cape Calhoun Formation (Morris Bugt Group) of Kap Calhoun, Washington Land, western North Greenland is described on the basis of a single specimen only $11 \mathrm{~mm}$ in length - about one quarter of the size of Offleya inexpectata. The Ordovician species is well illustrated by Troedsson (1928, pl. 1 , figs $1-10$ ) but the specimen is poorly preserved and now largely destroyed by sectioning. P. hyperboreus periodically develops strongly flared growth lamellae with crenulate margins, but lacks the uniformly crenulate lamellae and spiral ornamentation of $O$. inexpectata.

Phragmolites pinguis (Koken \& Perner, 1925) from the Upper Ordovician (5a) of Ringerike, Norway, is similar to Offleya inexpectata but more rapidly expanding, with narrower umbilici. The consistently wavy transverse ornamentation produced by the crenulate
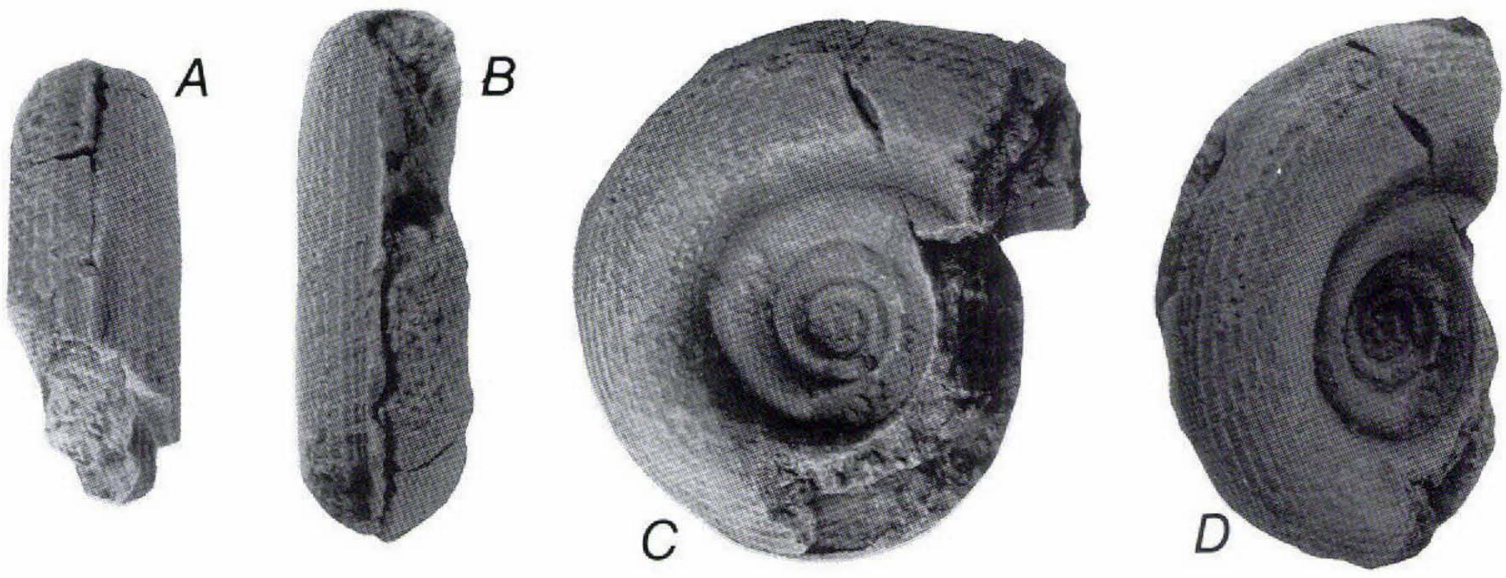

Fig. 41. Offleya inexpectata Poulsen, 1974, Lower Silurian Washington Land Group, northern coast of Offley $\emptyset$, western North Greenland. MMH 13.678, holotype and only known specimen, $\times 1.5$. A, dorsal view showing the selenizonal keel on the final preserved fraction of the whorl; B, dorsal view showing the damaged selenizone and the spiral ornamentation crossed by fine transverse growth lines; $\mathrm{C}$, lateral view showing the widely phaneromphalous umbilici and the reticulate ornamentation of the lateral areas of the whorl; D, oblique dorsal view showing ornamentation. 
growth lameliae in this species stands in contrast to the periodic crenulation seen in $P$. obliqua (Ulrich \& Scofield, 1897) and $P$. compressus Conrad, 1838, but the strong spiral elements present in $O$. inexpectata are lacking.

Phragmolites suarezi (Fischer, 1969) from the Lower Silurian of Bolivia is quite distinct from Offleya inexpectata and may be incorrectly placed at the generic level. The whorls of the South American species carry strong tubercles and are more triangular in shape (Fischer, 1969); it is closely related to the Cyrtolites euryomphalus of Lindström (1884) from the Lower Silurian Mulde Formation at Djupvik, Gotland.

Acknowledgements. Ellis L. Yochelson is thanked for reviewing the manuscript prior to publication. The following abbreviations in the text indicate institutions which kindly loaned specimens for examination: GGU, Geological Survey of Greenland, Copenhagen, Denmark; NMW, National Museum of Wales, Cardiff, U.K.; MMH and MGUH, Geological Museum, University of Copenhagen, Denmark; Mo, Naturhistoriska Riksmuseet, Stockholm, Sweden; USNM, U.S. National Museum of Natural History, Washington D.C., U.S.A.

Bente Thomas and Bodil Sikker Hansen (draughting), Jens Nymose and Jakob Lautrup (photographic processing) assisted in the production of the manuscript which was prepared for the printer by Esben W. Glendal.

\section{References}

Babin, C., Courtesole, R., Melou, M., Pillet, J., Vizcaino, D. \& Yochelson, E. L. 1982: Brachiopodes (articules) et molluscques (bivalves, rostroconches, monoplacophores, gastropodes) de l'Ordovicien inferieur (Tremadocien-Arenigien) de la Montagne Noire (France Meridionale). Mém. Soc. Etud. Sci. Aude, 63 pp.

Bassett, M. G., Kaljo, D. \& Teller, L. 1989: The Baltic region In Holland, C. H. \& Bassett, M. G. (ed.) A global standard for the Silurian System, 158-170. Cardiff: Nat. Museum Wales.

Challinor, J. 1945: Dr. Plot and Staffordshire geology. Trans. N. Staffs Field Club 79, 29-67.

Clarke, J. M. \& Ruedemann, R. 1903: Guelph fauna in the State of New York. Mem. N.Y. State Museum nat. Hist. 5 , $195 \mathrm{pp}$.

Conrad, T. A. 1838: Report on the palaeontological department of the survey. Ann. Rept. N.Y. geol. Survey 2, 107-119.

Eichwald, E. d' 1840: Ueber das silurische Schichtensystem in Esthland. Zeitschr. Nat-Heilkunde k. Med.-chirur. Akad. St. Petersburg 1, 1-114, 2, 115-210.

Eichwald, E. d' 1859: Lethaea rossica ou paléontologie de la Russie, décrite et figurée. Ancienne Période Atlas. Stuttgart. Eichwald, E. d' 1860: Lethaea rossica ou paléontologie de la Russie, décrite et figurée. 1, $681 \mathrm{pp}$. Stuttgart.
Fischer, J. C. 1969: Deux bellerophontacées nouveaux de Bolivie. Bull. Soc. géol. France 7, 605-608.

Fryda, 1988: A new species of Modestospira (Gastropoda) from the Ordovician of Bohemia. Vest. Ústred. úst. geol. 63, 227-232.

Hall, J. 1847: Palaeontology of New York, vol. 1, containing descriptions of the organic remains of the lower division of the New York System, (equivalent to the Lower Silurian rocks of Europe), 338 pp. Albany: Van Benthuysen.

Harper, J. A. \& Rollins, H. B. 1982: Recognition of Monoplacophora and Gastropoda in the fossil record: a functional morphological look at the bellerophont controversy. Proc. III N. Am. Paleont. Conv. 1, 227-232.

Horny, R. J. 1962: New genera of Bohemian Lower Paleozoic Bellerophontina. Vest. Ústred. úst. geol. 37, 473-476.

Horny, R. J. 1963: Lower Paleozoic Bellerophontina (Gastropoda) of Bohemia. Sbor. geol. Ved. Paleontologie 2, 57-164.

Horny, R. J. 1989: Bellerophacmaea gen. n. (Mollusca) and Palaelophacmaea Donaldson, 1962 (Coelenterata), an example of homeomorphy in invertebrate palaeozoology. Čas. národ. Mus. Praze 154 (for 1985), 119-124.

Horny, R. J. 1990: Muscle scars in Sinuites (Strangulites) (Mollusca) from the Ordovician of Bohemia. Cas. národ. Mus. Praze 155 (for 1986), 109-118.

Horny, R. J. in press a: Shell morphology and muscle scars of Sinuitopsis neglecta Perner (Mollusca, Monoplacophora). Čas. národ. Mus. Praze.

Horny, R. J. in press b: Muscle scars in Sinuites (Mollusca, Gastropoda) from the Lower Ordovician of Bohemia. Cas. národ. Mus. Praze.

Knight, J. B. 1941: Paleozoic gastropod genotypes. Spec. Pap. geol. Soc. Am. 32, 510 pp.

Knight, J. B. 1947: Bellerophont muscle scars. Jour. Paleont. 21, 264-267.

Knight, J. B. 1952: Primitive fossil gastropods and their bearing on gastropod classification. Smithson. Misc. Colls 114, $13,1-55$.

Knight, J. B., Cox, L. R., Keen, A. M., Batten, R. L., Yochelson, E. L. \& Robertson, R. 1960: Systematic descriptions. In Moore, R. C. (ed.) Treatise on invertebrate paleontology, I, Mollusca 1, I169-I310. Lawrence: Univ. Kansas Press and Geol. Soc. Am.

Koken, E. 1889: Ueber die Entwicklung der Gastropoden vom Cambrium bis zur Trias. Neues Jahrb. Mineral. Geol. Paläont. 6, 305-484.

Koken, E. \& Perner, L. 1925: Die Gastropoden des baltischen Untersilurs. Mém. Acad. Sci. Russie, Leningrad 37, 1-326.

Koninck, L. G. de 1842-44: Description des animaux fossiles, quise trouvent dans le terrain carbonifiére de Belgique, 651 pp. Liége.

Lemche, H. 1957: A new living deep-sea mollusc of the Cambro-Devonian Class Monoplacophora. Nature 179, 413-416.

Lemche, H. \& Wingstrand, K. G. 1959: The anatomy of Neopilina galatheae Lemche, 1957. Galathea Rept 3, 9-71.

Lindström, G. 1884: On the Silurian Gastropoda and Pteropoda of Gotland. K. svenska Vetenskaps Akad. Handl. 19, $250 \mathrm{pp}$ 
Linsley, R. M. 1977: Some 'laws' of gastropod shell form. Paleobiology 3, 196-206.

Linsley, R. M. 1978: Shell form and evolution of the gastropods. Amer. Sci. 66, 432-441.

McNair, C. G., Kier, W. M., Lacroix, P. D. \& Linsley, R. M. 1981: The functional significance of aperture form in gastropods. Lethaia 14, 63-70.

Meek, F. B. 1866: Notes on the affinities of the Bellerophontidae. Proc. Chicago Acad. Sci. 1, 9-11.

Moore, R. C. 1941: Upper Pennsylvanian gastropods from Kansas. Bull. Kansas geol. Surv. 38, 121-163.

Murchison, R. I. 1839: The Silurian System, 768 pp. London.

Newton, R. B. 1892a: On the American Palaeozoic gasteropod Trematonotus (Hall emend. P. Fischer) and its identification in Britain; with a description of a new species. Geol. Mag. 9, 337-341.

Newton, R. B. 1892b: On the genus Trematonotus. Geol. Mag. 9, 525 only.

Peel, J. S. 1972: Observations on some Lower Palaeozoic tremanotiform Bellerophontacea (Gastropoda) from North America. Palaeontology 15, 412-422.

Peel, J. S. 1974: Systematics, ontogeny and functional morphology of Silurian trilobed bellerophontacean gastropods. Bull. geol. Soc. Denmark 23, 231-264.

Peel, J. S. 1976: Musculature and systematic position of Megalomphala taenia (Bellerophontacea, Gastropoda) from the Silurian of Gotland. Bull. geol. Soc. Denmark 25, 49-55.

Peel, J. S. 1977b: Systematics and palaeontology of the Silurian gastropods of the Arisaig Group, Nova Scotia. Biol. Skr. Dansk Videnskabs. Selsk. 21(2), 89 pp.

Peel, J. S. 1984: Autecology of Silurian gastropods and monoplacophorans. Spec. Pap. Palaeontology 32, 165-182.

Peel, J. S. 1991a: Functional morphology of the Class Helcionelloida nov., and the early evolution of the Mollusca. In Simonetta, A. \& Conway Morris, S. (ed.) The early evolution of Metazoa and the significance of problematic taxa, 157-177. Cambridge: Cambridge Univ. Press and Univ. Camerino.

Peel, J. S. 1991b: The classes Tergomya and Helcionelloida and early molluscan evolution. Bull. Gronlands geol. Unders. 161 (this volume).

Plot, R. 1686: The natural history of Staffordshire, $460 \mathrm{pp}$. Oxford: The Theater. Republished by E. J. Morten, Manchester, 1973

Poulsen, C. 1974: Silurian Pelecypoda, Monoplacophora, and Gastropoda from the reefy facies of the Offley Island Formation of Washington Land and Offley Island (Northwest Greenland). Biol. Skr. Dansk Videnskabs. Selsk. 20(7), 18 pp.
Reed, F. R. C. 1920-21: British Ordovician and Silurian Bellerophontacea. Monogr. Palaeontogr. Soc. $92 \mathrm{pp}$.

Roemer, C. F. von 1876: Lethaea geognostica oder Beschreibung und Abbildung der für die Gebirgs-Formationen bezeichnendsten Versteinerungen, 1 Theil, Lethaea palaeozoica, 323 pp. Stuttgart.

Rollins, H. B. \& Batten, R. L. 1968: A sinus-bearing monoplacophoran and its role in the classification of primitive molluses. Palaeontology 11, 132-140.

Runnegar, B., \& Jell, P. A. 1976: Australian Middle Cambrian molluscs and their bearing on early molluscan evolution. Alcheringa 1, 109-138.

Runnegar, B., \& Pojeta, J., Jr. 1974: Molluscan phylogeny: the paleontological viewpoint. Science 186, 311-317.

Tassell, C. B. 1976: A revision of the gastropod fauna of the Lilydale Limestone (Early Devonian) of Victoria. Mem. Nat. Mus. Victoria 37, 1-22.

Troedsson, G. T. 1928: On the Middle and Upper Ordovician faunas of Northern Greenland. Part II. Meddr Grønland 72(1), $197 \mathrm{pp}$.

Ulrich, E. O. \& Scofield, W. H. 1897: The Lower Silurian Gastropoda of Minnesota. Geology of Minnesota. Final Rept. Geol. Surv. Minnesota 3(2), 813-1081.

Vostokova, V. A. 1960: Semestvo Bucaniidae. In Orlov, Yu. A. (ed.) Osnovy paleontologii, [Mollusca-Gastropoda], 61-62. Moscow: Gos. Nauchno-Tech. Izdat. Lit. Geol. Ochrane Nedr.

Wenz, W. 1938-44: Gastropoda. Allgemeiner Teil und Prosobranchia. In Schindewolf, O. H. (ed.) Handbuch der Paläozoologie 6, $1639 \mathrm{pp}$. Berlin: Gebrüder Borntraeger.

Wenz, W. 1940: Ursprung und frühe Stammesgeschichte der Gastropoden. Arch. Molluskenk. 72, 1-10.

Wingstrand, K. G. 1985: On the anatomy and relationships of Recent Monoplacophora. Galathaea Rept 16, 7-94.

Yochelson, E. L. 1967: Quo vadis, Bellerophon? In Teichert, C. \& Yochelson, E. L. (ed.) Essays in paleontology and stratigraphy, 141-161. Lawrence: Univ. Kansas Press.

Yochelson, E. L. 1978: An alternative approach to the interpretation of the phylogeny of ancient molluscs. Malacologia 17, 165-191.

Yochelson, E. L. 1984: Historic and current considerations for revision of Paleozoic gastropod classification. Jour. Paleont. 58, 259-269.

Yochelson, E. L. \& Nuelle, L. M. 1985: Strepsodiscus (Gastropoda) in the Late Cambrian of Missouri. Jour. Paleont. 59, 733-740.

Yonge, C. M., \& Thompson, T. E. 1976: Living marine molluscs, $288 \mathrm{pp}$. London: Collins. 
